Nevada

DOE/NV/11718--283

Environmental

Restoration

Project

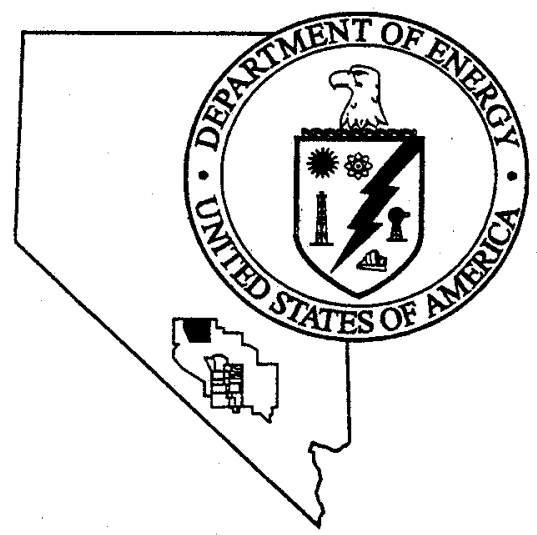

Closure Report for

Corrective Action Unit 424:

Area 3 Landfill Complex,

Tonopah Test Range, Nevada

Controlled Copy No.:

Revision No.: 0

July 1999

Distribution A - Approved for public release; further dissemination unlimited.

Environmental Restoration

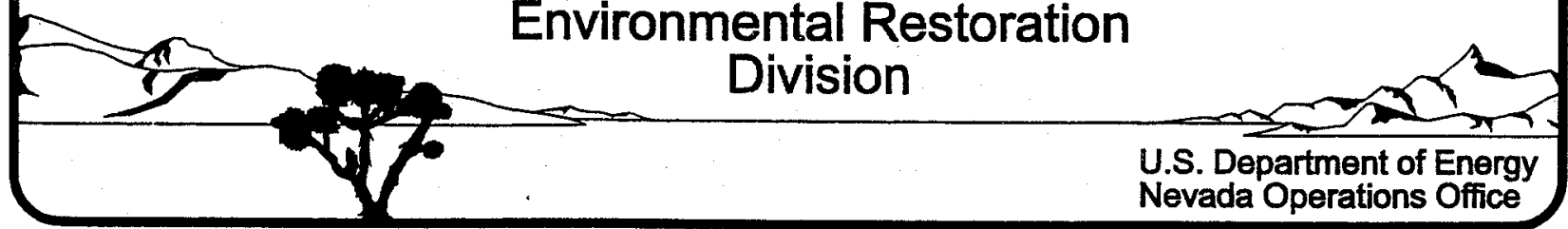


Available to the public from:

U.S. Department of Commerce

National Technical Information Service

5285 Port Royal Road

Springfield, VA, 22161-0002

(703) $487-4650$

Available electronically at http://www.doe.gov/bridge. Available to U.S. Department of Energy and its contractors in paper from:

U.S. Department of Energy

Office of Scientific and Technical Information

P.O. Box 62

Oak Ridge, TN, 37831-0062

(423) $576-8401$

Reference herein to any specific commercial product, process, or service by trade name, trademark, manufacturer, or otherwise, does not necessarily constitute or imply its endorsement, recommendation, or favoring by the U.S. Government or any agency thereof or its contractors or subcontractors. 


\title{
Closure Report For Corrective Action Unit 424: Area 3 Landfill Complex Tonopah Test Range, Nevada
}

\author{
Prepared for \\ U. S. Department of Energy \\ Nevada Operations Office \\ Work Performed Under Contract No. \\ DE-AC08-96NV11718
}

Controlled Copy No.:

Revision: 0

June 1999 
THIS PAGE INTENTIONALLY LEFT BLANK 


\section{Closure Report For Corrective Action Unit 424: Area 3 Landfill Complex Tonopah Test Range, Nevada}

Approved by:

Janet L. Appenzeller-Wing, Project Manager Industrial Sites Subproject

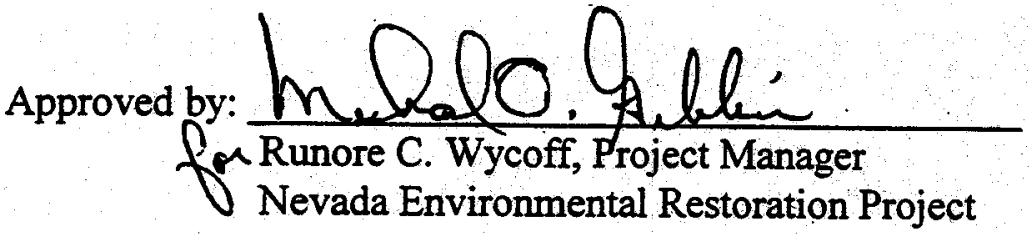

Date:

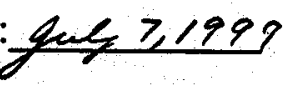

-

Date: $7-7-1999$ 
THIS P.AGE INTENTIONALLY LEFT BLANK 


\section{TABLE OF CONTENTS}

ACRONYMS AND ABBREVIATIONS $\ldots \ldots \ldots \ldots \ldots \ldots \ldots \ldots \ldots \ldots \ldots \ldots$

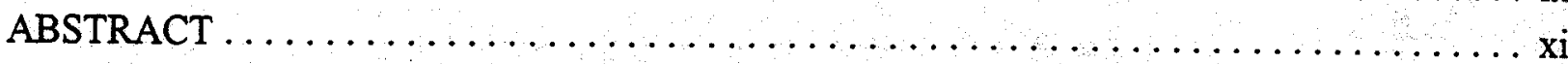

1.0 INTRODUCTION $\ldots \ldots \ldots \ldots \ldots \ldots \ldots \ldots \ldots \ldots \ldots \ldots \ldots \ldots \ldots \ldots \ldots \ldots \ldots \ldots \ldots 1$

1.1 Purpose $\ldots \ldots \ldots \ldots \ldots \ldots \ldots \ldots \ldots \ldots \ldots \ldots \ldots \ldots \ldots \ldots \ldots \ldots \ldots \ldots \ldots \ldots \ldots 11$

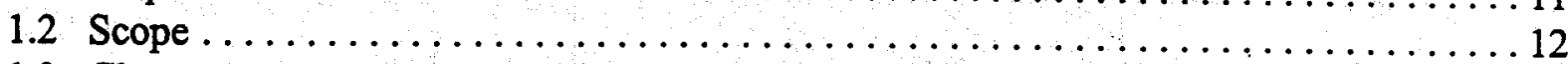

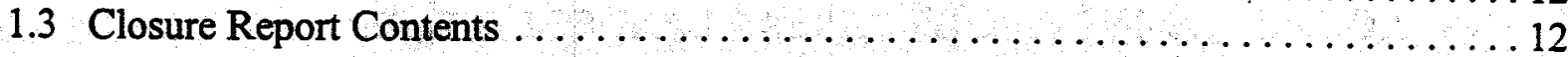

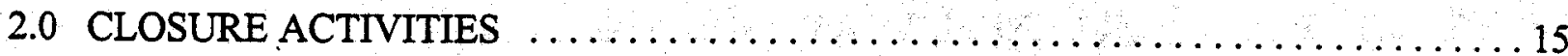

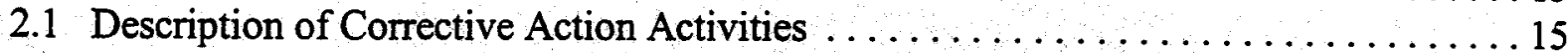

2.1.1 Petroleum Hydrocarbon-Impacted Wastes at Landfill A3-2 $\ldots \ldots \ldots \ldots \ldots 15$

2.1.1.1 Investigation of Reported Buried Diesel Storage Tank . . . . . . . 15

2.1.1.2 Excavation of Reported Sludge-Impacted Area ............. 17

2.1.2 Repair and Maintenance of Soil Covers ... . . . . . . . . . . . . . . 19

2.1.2.1 Preparation and Conditioning of Borrow Material ............ 19

2.1.2.2 Backfill of Surface Depressions .................... 19

2.1.3 Installation of Markers and Warning Signs $\ldots \ldots \ldots \ldots \ldots \ldots \ldots \ldots \ldots \ldots 20$

2.2 Deviations From Corrective Action Plan As Approved . . . . . . . . . . . . 21

2.3 Corrective Action Schedule As Completed $\ldots \ldots \ldots \ldots \ldots \ldots \ldots \ldots \ldots \ldots \ldots \ldots 21$

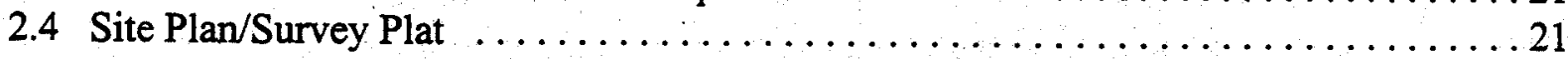

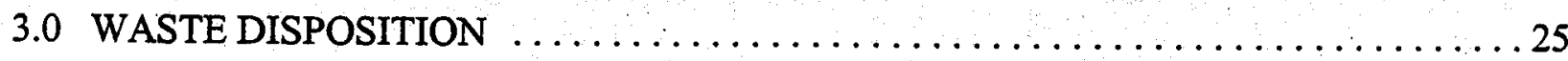

4.0 CLOSURE VERIFICATION RESULTS $\ldots \ldots \ldots \ldots \ldots \ldots \ldots \ldots \ldots \ldots \ldots \ldots \ldots \ldots \ldots 29$

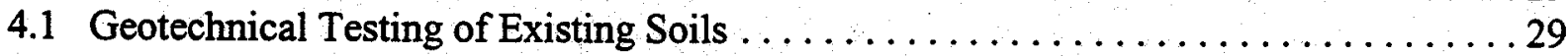

4.2 Field Compaction Testing of Backfill $\ldots \ldots \ldots \ldots \ldots \ldots \ldots \ldots \ldots \ldots \ldots \ldots \ldots \ldots \ldots \ldots \ldots \ldots$

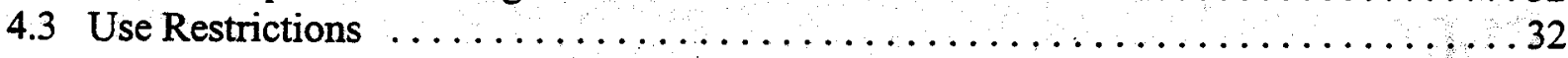

5.0 POST-CLOSURE INSPECTION PLAN $\ldots \ldots \ldots \ldots \ldots \ldots \ldots \ldots \ldots \ldots \ldots \ldots \ldots \ldots 33$

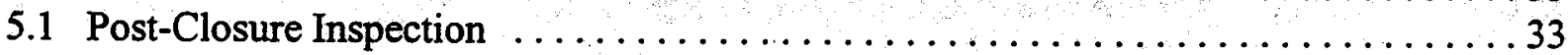

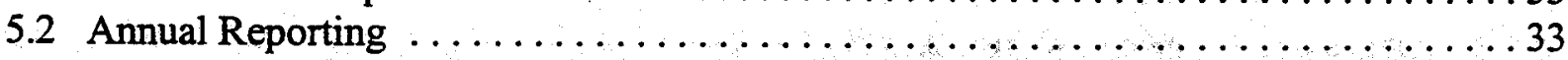

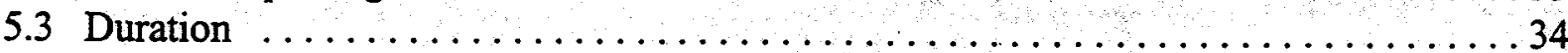

6.0 SUMMARY, CONCLUSIONS AND RECOMMENDATIONS $\ldots \ldots \ldots \ldots \ldots \ldots \ldots 35$

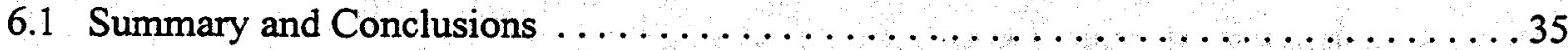

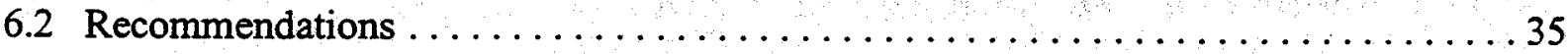

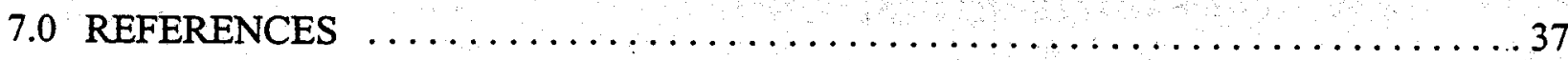




\section{TABLE OF CONTENTS (continued)}

\section{FIGURES}

FIGURE 1 - LOCATION OF THE AREA 3 LANDFILL COMPLEX AT THE TONOPAH TEST RANGE $\ldots \ldots \ldots \ldots \ldots \ldots \ldots \ldots \ldots \ldots \ldots \ldots \ldots \ldots$

FIGURE 2 - LOCATIONS OF THE EIGHT AREA 3 LANDFILL SITES $\ldots \ldots \ldots \ldots \ldots . \ldots$

FIGURE 3 - SITE PLANS FOR LANDFILLS A3-1 AND A3-2 $\ldots \ldots \ldots \ldots \ldots \ldots \ldots$

FIGURE 4 - SITE PLAN FOR LANDFILL A3-3 $\ldots \ldots \ldots \ldots \ldots \ldots \ldots \ldots \ldots \ldots \ldots \ldots \ldots \ldots$

FIGURE 5 - SITE PLAN FOR LANDFILL A3-4 $\ldots \ldots \ldots \ldots \ldots \ldots \ldots \ldots \ldots$

FIGURE 6 - SITE PLAN FOR LANDFILL A3-5 $\ldots \ldots \ldots \ldots \ldots \ldots \ldots \ldots \ldots$

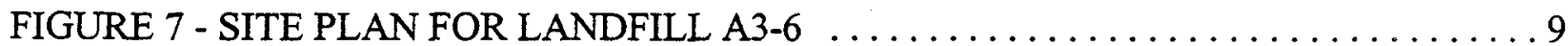

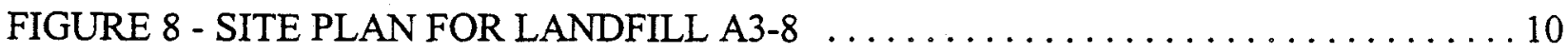

FIGURE 9 - CORRECTIVE ACTION SCHEDULE AS COMPLETED . . . . . . . . . . 22

FIGURE 10 - TOPOGRAPHY IN THE VICINITY OF THE AREA 3 LANDFILL

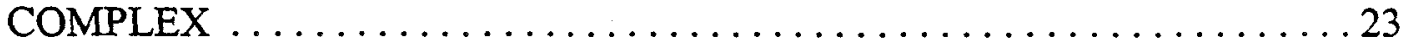

\section{TABLES}

TABLE 1 - SUMMARY OF LANDFILL CHARACTERISTICS $\ldots \ldots \ldots \ldots \ldots \ldots \ldots$

TABLE 2 - SUMMARY OF CLOSURE ACTIVITIES $\ldots \ldots \ldots \ldots \ldots \ldots \ldots \ldots \ldots \ldots \ldots \ldots \ldots \ldots$

TABLE 3 - SUMMARY OF FIELD AND LABORATORY TPH TESTS $\ldots \ldots \ldots \ldots \ldots 18$

TABLE 4 - SUMMARY OF 1998 ANALYTICAL RESULTS . . . . . . . . . . . . . . . 26

TABLE 5 - SUMMARY OF GEOTECHNICAL TESTS $\ldots \ldots \ldots \ldots \ldots \ldots \ldots \ldots \ldots \ldots \ldots$ 


\section{TABLE OF CONTENTS (continued)}

\section{APPENDICES}

APPENDIX A - ANALYTICAL LABORATORY REPORT FOR LANDFILL A3-2 CLOSURE APPENDIX B - AS-BUILT ENGINEERING DRAWINGS

APPENDIX C - WASTE DISPOSAL DOCUMENTATION

APPENDIX D - GEOTECHNICAL TEST RESULTS

APPENDIX E - USE RESTRICTION DOCUMENTATION

APPENDIX F - POST-CLOSURE INSPECTION CHECKLIST

APPENDIX G - NDEP DOCUMENT REVIEW SHEET 
THIS PAGE INTENTIONALLY LEFT BLANK

viii 


\section{ACRONYMS AND ABBREVIATIONS}

CADD Corrective Action Decision Document

CAIP Corrective Action Investigation Plan

CAP Corrective Action Plan

CAS Corrective Action Site

CAU Corrective Action Unit

$\mathrm{cm} / \mathrm{sec} \quad$ centimeter per second

COC Constituent of Concern

CR Closure Report

DOE U.S. Department of Energy

DOE/NV U.S. Department of Energy, Nevada Operations Office

EPA U.S. Environmental Protection Agency

FFACO Federal Facilities Agreement and Consent Order

$\mathrm{ft} \quad$ foot

$\mathrm{lb} / \mathrm{ft}^{3} \quad$ pound per cubic foot

gal gallon

in inch

$\mathrm{kg} / \mathrm{m}^{3} \quad$ kilogram per cubic meter

km kilometer

L liter 


\section{ACRONYMS AND ABBREVIATIONS (continued)}

m meter

$\mathrm{m}^{3} \quad$ cubic meter

mi mile

$\mathrm{mg} / \mathrm{kg} \quad$ milligram per kilogram

NDEP Nevada Division of Environmental Protection

NTS Nevada Test Site

ppm part per million

PRG Preliminary Remediation Goal

RCRA Resource Conservation and Recovery Act

SVOC semi-volatile organic compound

TCLP Toxicity Characteristic Leachate Procedure

TPH total petroleum hydrocarbons

TTR Tonopah Test Range

$\mu \mathrm{g} / \mathrm{kg} \quad$ microgram per kilogram

USAF United States Air Force

VOC volatile organic compound

$\mathrm{yd}^{3} \quad$ cubic yard 


\section{ABSTRACT}

This Closure Report provides the documentation for closure of the Area 3 Landfill Complex Corrective Action Unit (CAU) 424. The site is located on the Tonopah Test Range, approximately 225 kilometers (140 miles) northwest of Las Vegas, Nevada.

CAU 424 consists of eight sites, designated as A3-1 through A3-8, where landfill waste cells were believed to have operated during different time intervals from before 1963 to approximately 1993. The locations and contents of the landfill waste cells were poorly documented due to the unregulated disposal practices commonly associated with early operation of the landfills. A corrective action investigation performed in 1997 was documented in the Corrective Action Decision Document (CADD) and reported that landfill wastes were found at all sites except A37. The CADD concluded that site A3-7, as well as a number of suspected individual waste cells and/or geophysical anomalies within five other sites, were not landfill cells (U.S. Department of Energy [DOE], 1998a). The CADD reported that petroleum-hydrocarbon impacted soils were found at Landfills A3-1 and A3-2, and that surface depressions existed at a number of the sites.

Three remedial alternatives were selected in the CADD (DOE, 1998a) for CAU 424: no action (Alternative 1) for site A3-7; removal of petroleum hydrocarbon wastes (Alternative 3) for Landfill A3-2; and administrative closure (Alternative 2) for the six other sites. The Nevada Division of Environmental Protection (NDEP)-approved Corrective Action Plan (CAP) proposed the closure methods (DOE, 1998b). The following closure activities were completed following the approved CAP: removal of A3-2 petroleum hydrocarbon waste; repair and maintenance of landfill soil covers (backfilling and compaction of surface depressions, including the A3-2 excavation); installation of landfill location markers and warning signs; and implementation of use restrictions.

Since closure activities for CAU 424 have been completed following the NDEP-approved CAP (DOE, 1998b) as documented in this Closure Report, the U.S. Department of Energy, Nevada Operations Office requests that:

CAU 424 be moved from Appendix III to Appendix IV of the Federal Facility Agreement and Consent Order.

NDEP provide a Notice of Completion to the U.S. Department of Energy, Nevada Operations Office. 
THIS PAGE INTENTIONALLY LEFT BLANK 


\subsection{INTRODUCTION}

The U.S. Department of Energy, Nevada Operations Office (DOE/NV) operates the Nevada Test Site (NTS) and entered into a trilateral agreement with the state of Nevada and the U.S. Defense Threat Reduction Agency. The trilateral agreement, the Federal Facilities Agreement and Consent Order (FFACO), provides a framework for identifying, characterizing, remediating, and closing DOE/NV environmental sites in Nevada (FFACO, 1996). Corrective Action Units (CAUs) have been identified in the FFACO at the Tonopah Test Range (TTR) which is currently operated by the U.S. Department of Energy, Albuquerque Operations Office, and U.S. Air Force (USAF).

This Closure Report (CR) provides documentation for the closure of the Area 3 Landfill Complex CAU 424, as proposed in the Corrective Action Plan (CAP) (DOE, 1998b). The site is located on the TTR, approximately 225 kilometers $(\mathrm{km})(140$ miles [mi]) northwest of Las Vegas, Nevada (Figure 1).

CAU 424 consists of eight landfill sites (Figure 2), each designated as a separate Corrective Action Site (CAS). In general, each landfill site is comprised of one or more buried waste cells which received wastes from daily operations at the Area 3 Compound during different time intervals from before 1963 to approximately 1993 . Waste cell locations and contents were poorly documented due to the unregulated disposal practices commonly associated with early landfill operations. Available process knowledge does not indicate the disposal of hazardous wastes. The Corrective Action Investigation Plan (CAIP) (DOE, 1997) described how potential waste cell locations were identified and proposed a field investigation to verify and characterize the suspected waste cells. The field investigation was performed in 1997 and was reported in the Corrective Action Decision Document (CADD) (DOE, 1998a). The findings in each landfill site are summarized in Table 1.

Landfill A3-1 consists of four buried waste cells and one large open waste cell that was partially filled with construction debris (Figure 3). Landfill debris was found in 11 of 13 soil borings. Total petroleum hydrocarbon (TPH) was identified as the only constituent of concern (COC) and was found in one boring (BH1-13) between the depths of 2.1 and 10.4 meters $(\mathrm{m})(7$ and 34 feet [ft]) as gasoline (in concentrations up to 200 milligrams per kilogram ( $\mathrm{mg} / \mathrm{kg}$ ) and diesel (in concentrations up to $790 \mathrm{mg} / \mathrm{kg}$ ), exceeding the Regulatory Action Level for TPH of $100 \mathrm{mg} / \mathrm{kg}$. A surface depression designated as cell A3-1 a was no longer suspected to be a waste cell after no landfill debris or COCs were found in two other borings, but backfilling of the surface depression was recommended to minimize ponding, infiltration, and erosion.

Landfill A3-2 consists of one buried waste cell (Figure 3). Landfill debris was found in four of the six borings. Petroleum hydrocarbon sludge was found in soil boring BH2-3 at a depth of $3 \mathrm{~m}$ (10 ft) and identified as waste oil at a concentration of $48,000 \mathrm{mg} / \mathrm{kg}$, exceeding the Regulatory Action Level for TPH of $100 \mathrm{mg} / \mathrm{kg}$. A subsidence sinkhole revealed the presence of a buried 

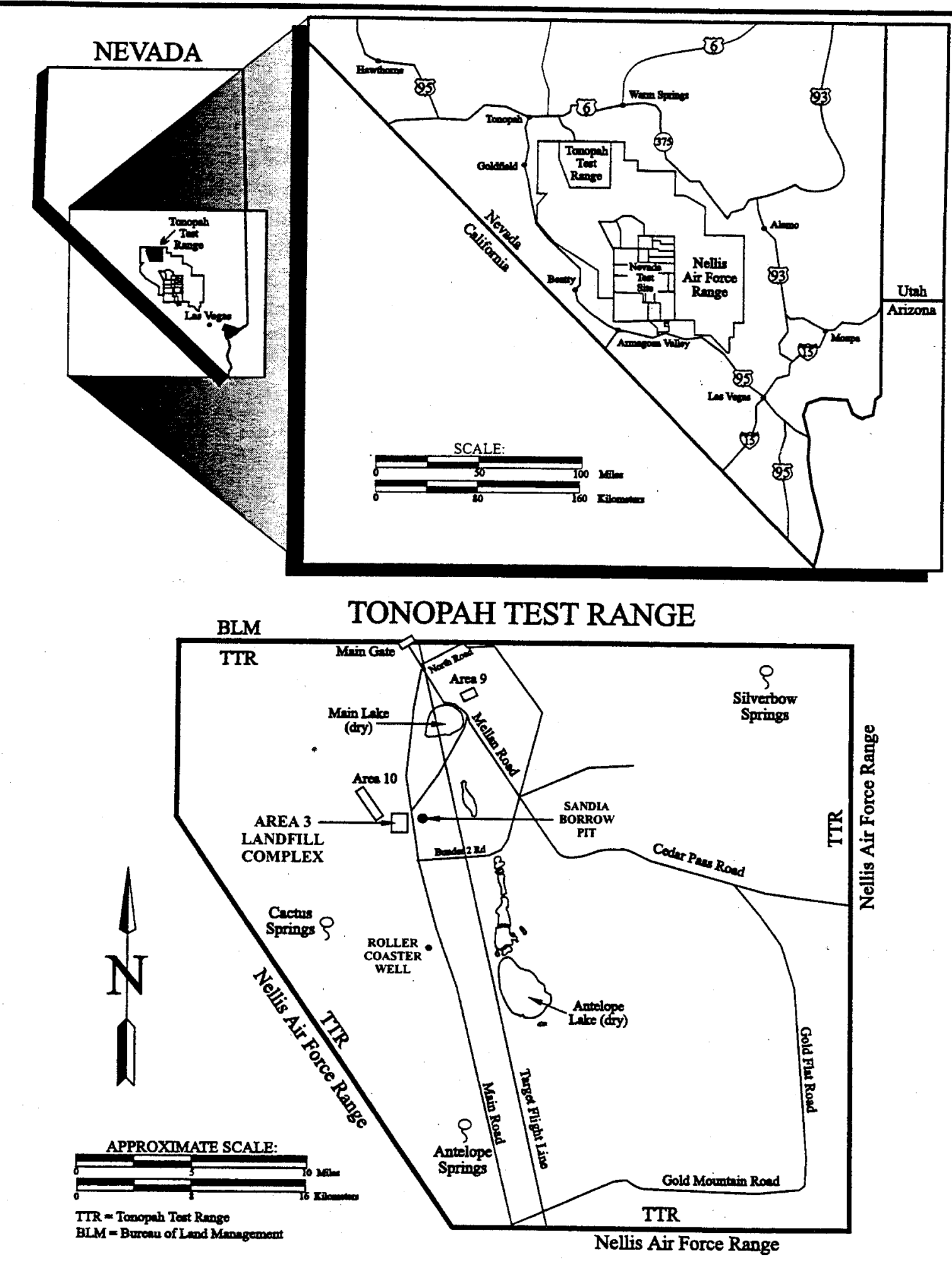

\section{FIGURE 1}

LOCATION OF THE AREA 3 LANDFILL COMPLEX AT THE TONOPAH TEST RANGE 


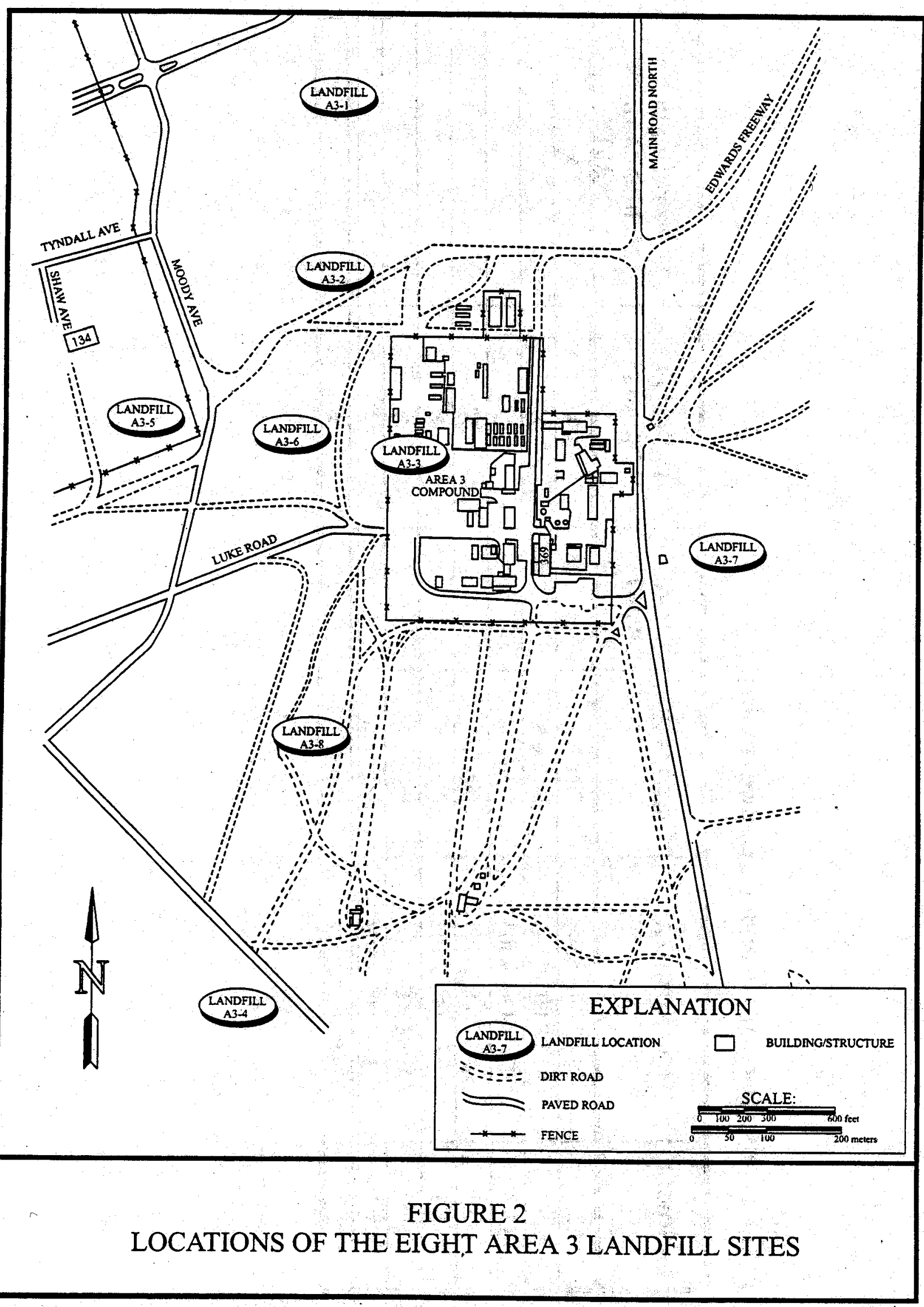



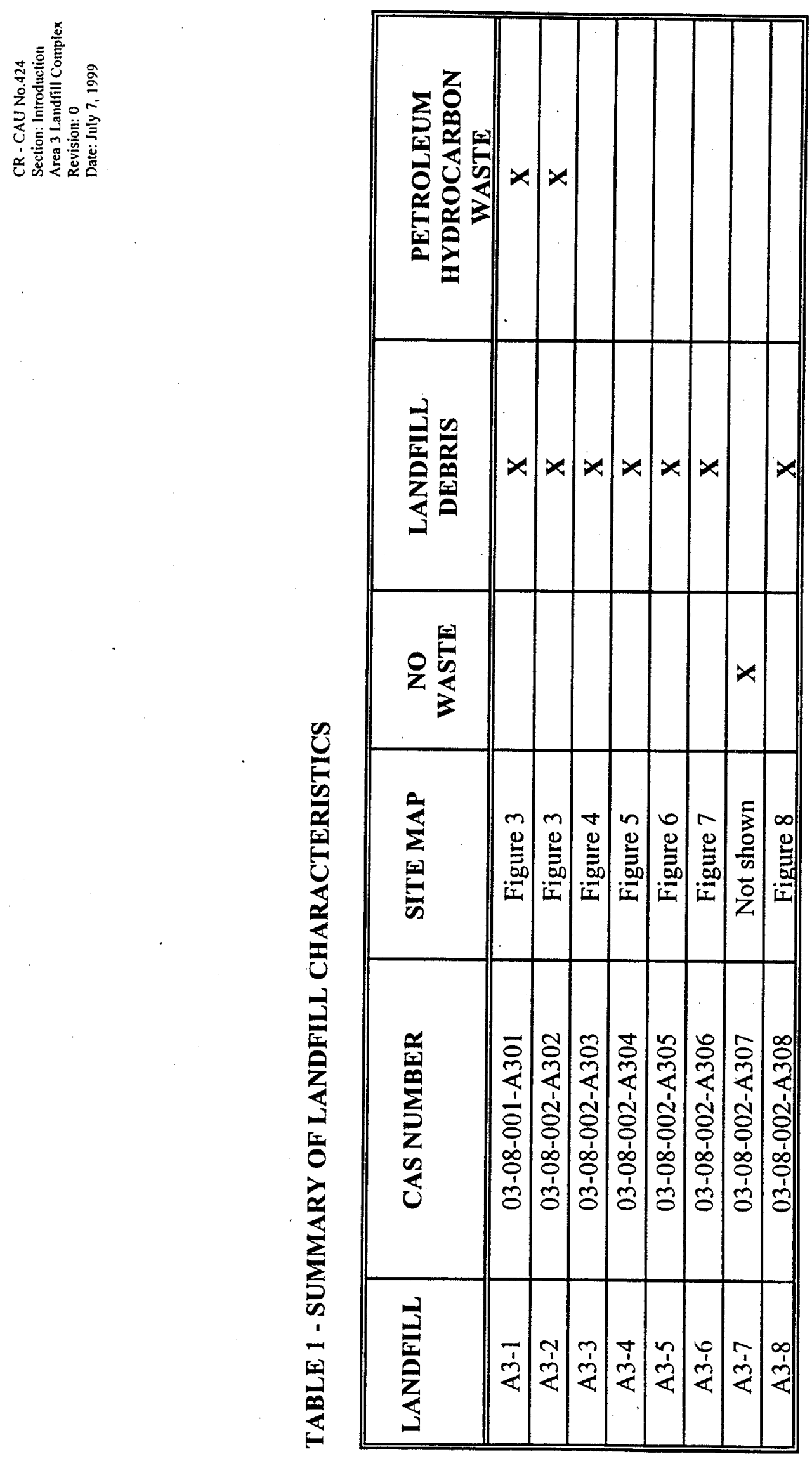


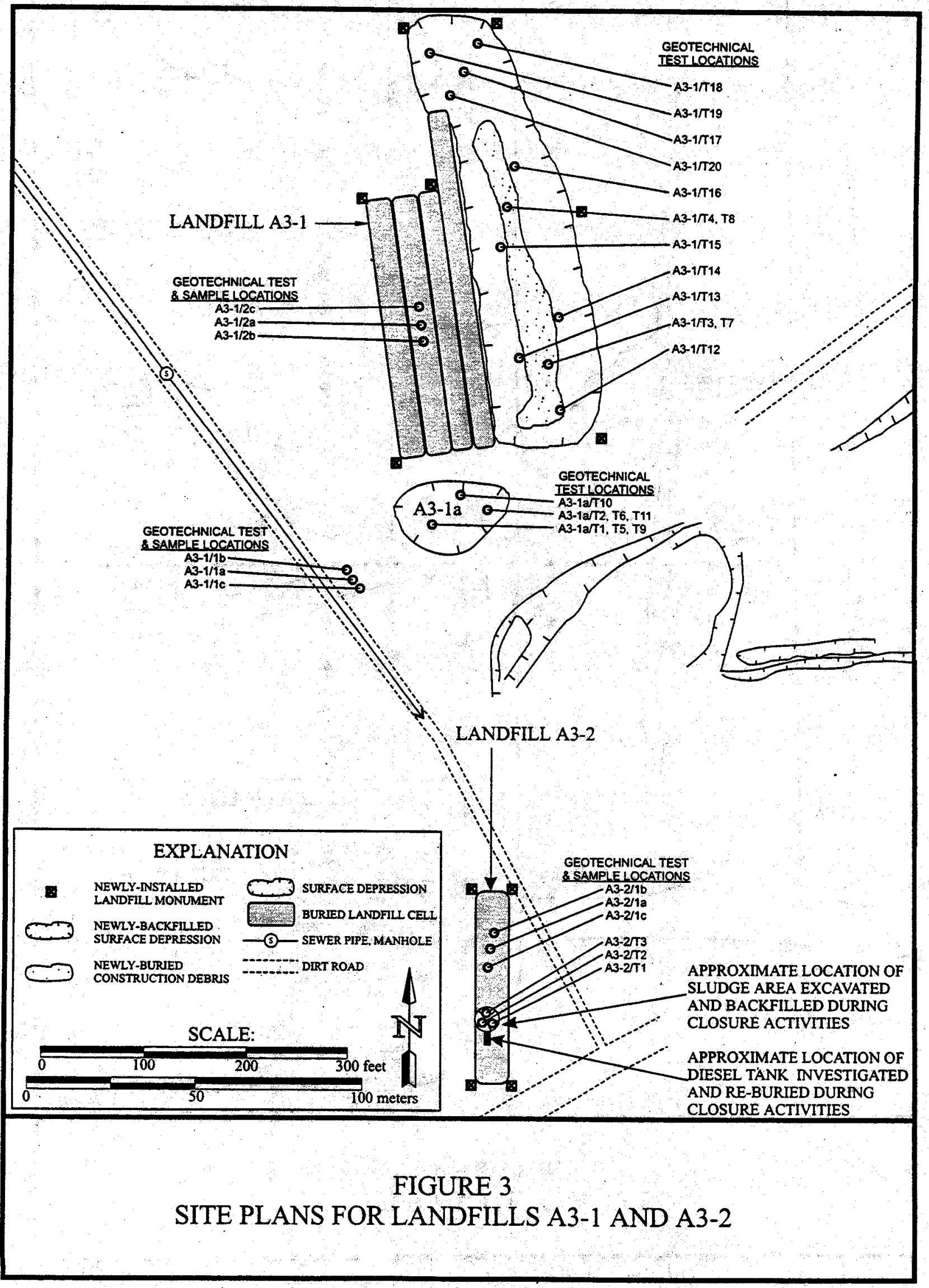




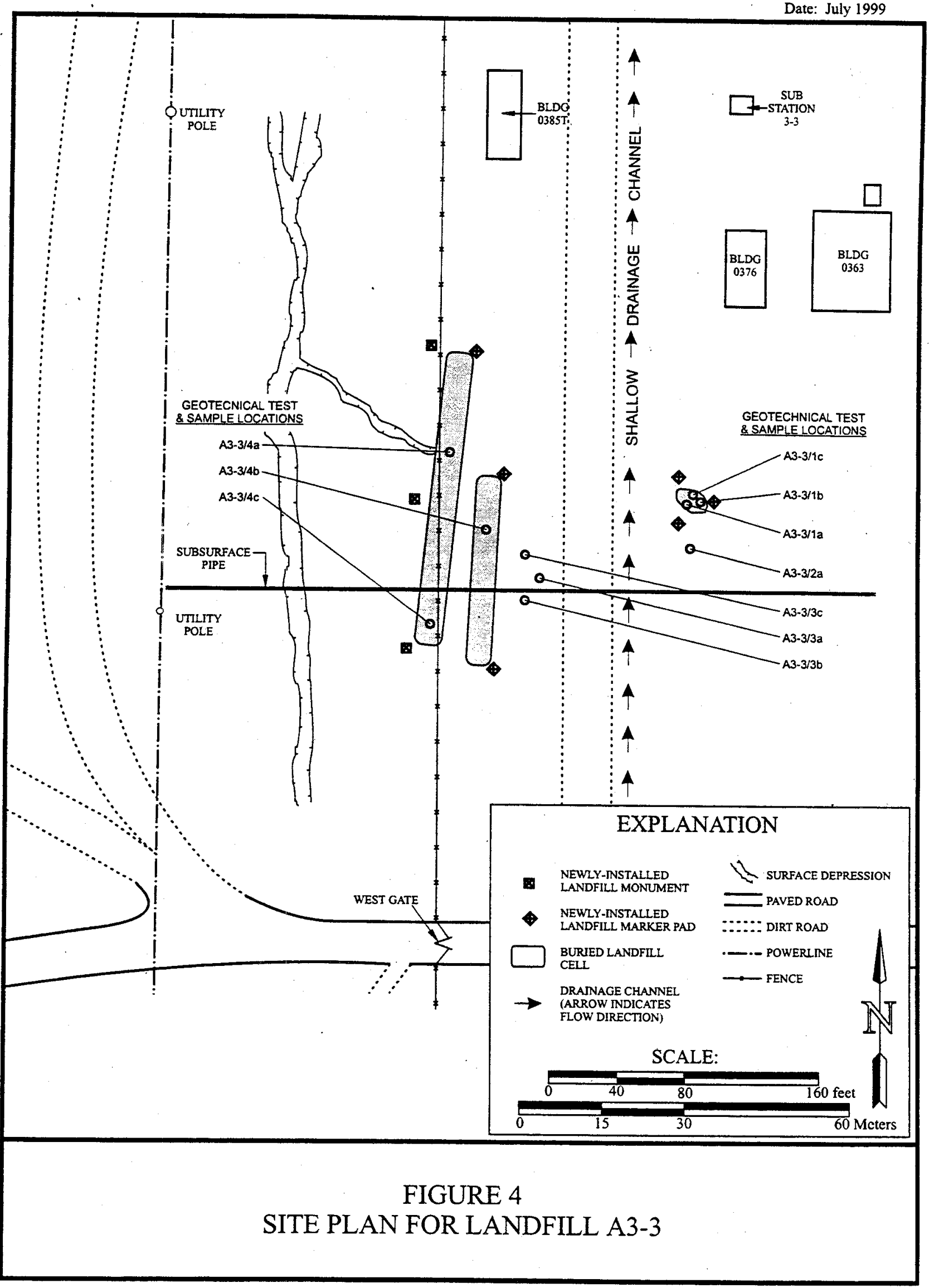


CR - CAU No 424

Section: Introduction

Revision: 0

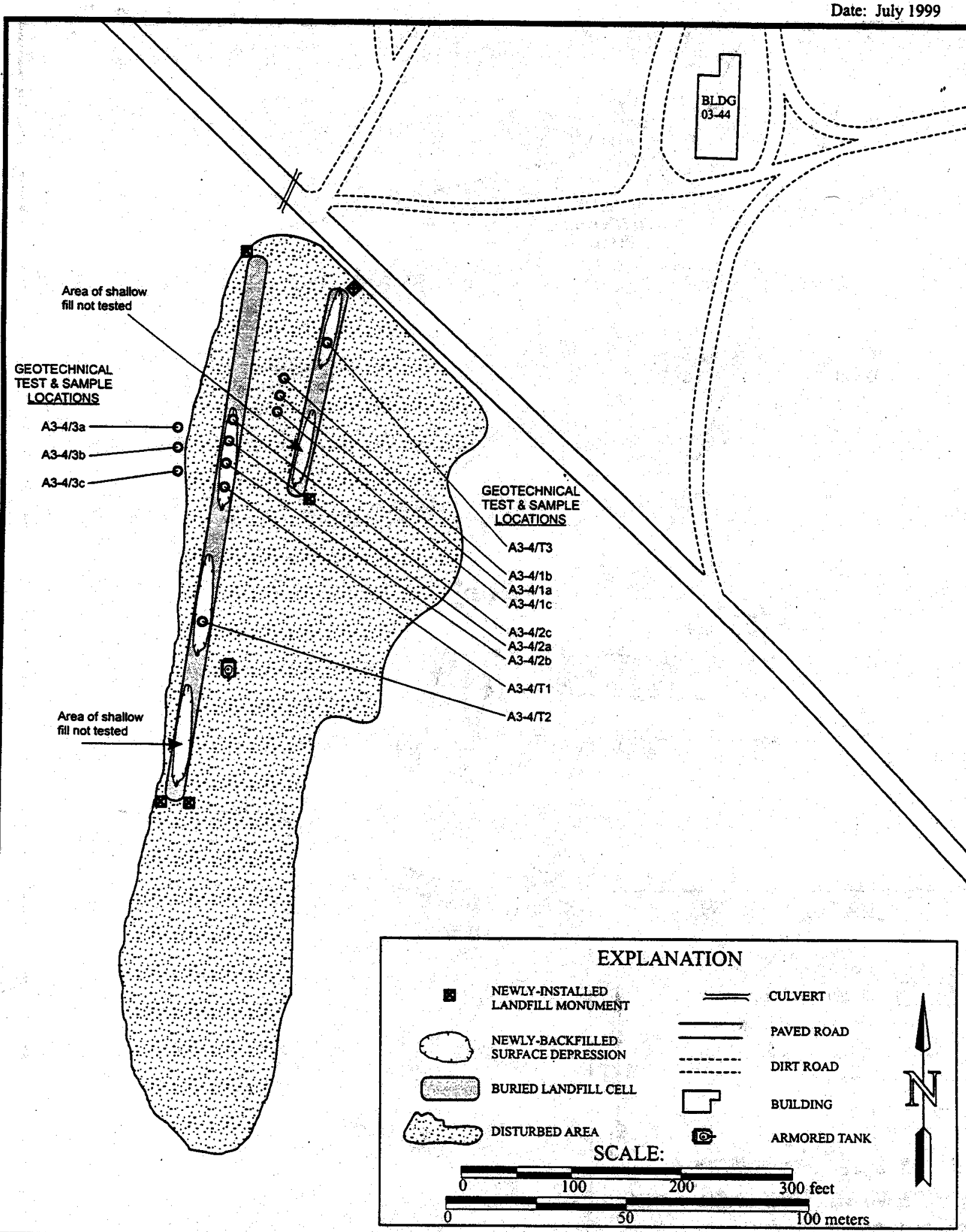

FIGURE 5

SITE PLAN FOR LANDFILL A3-4 


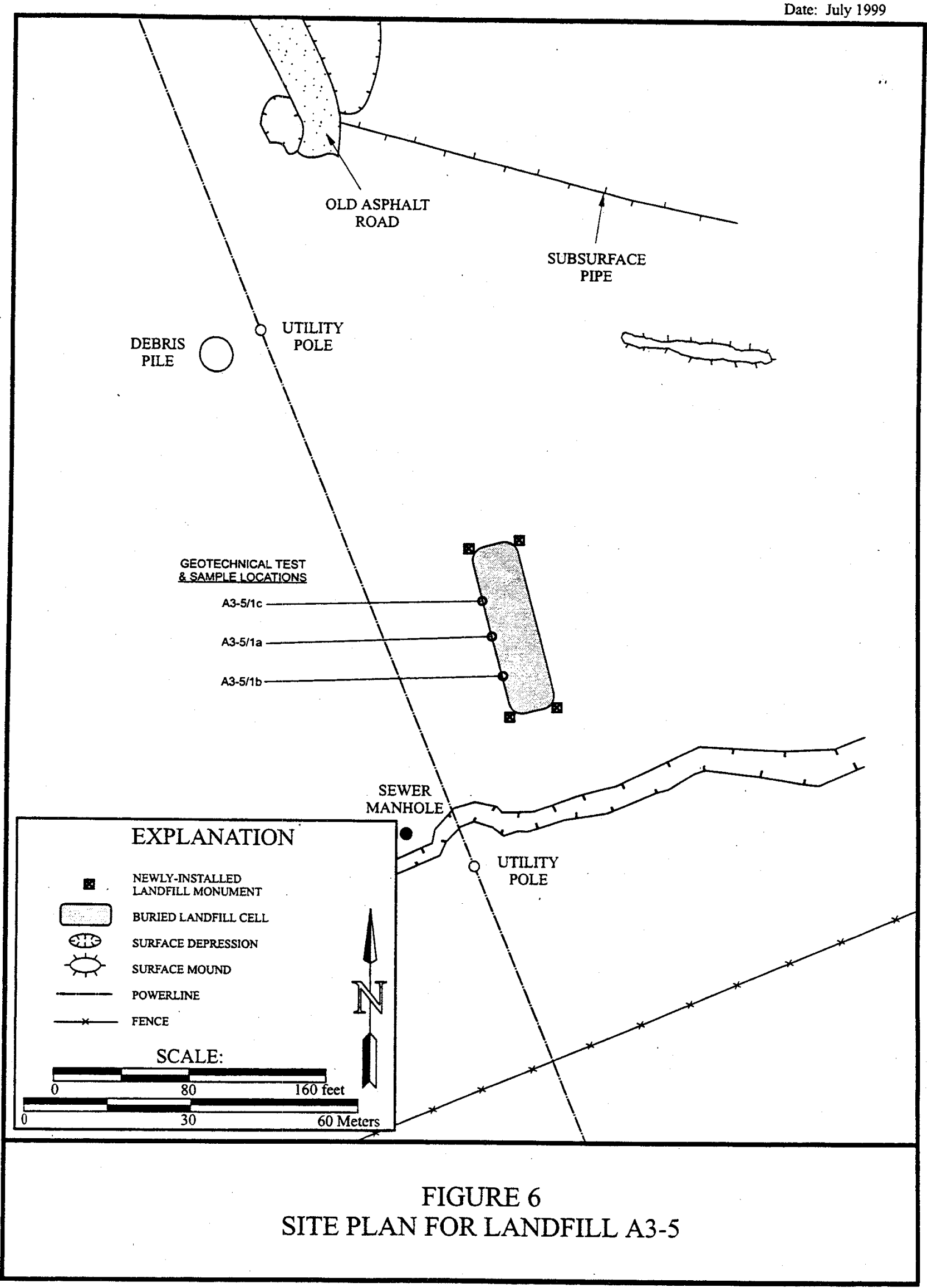




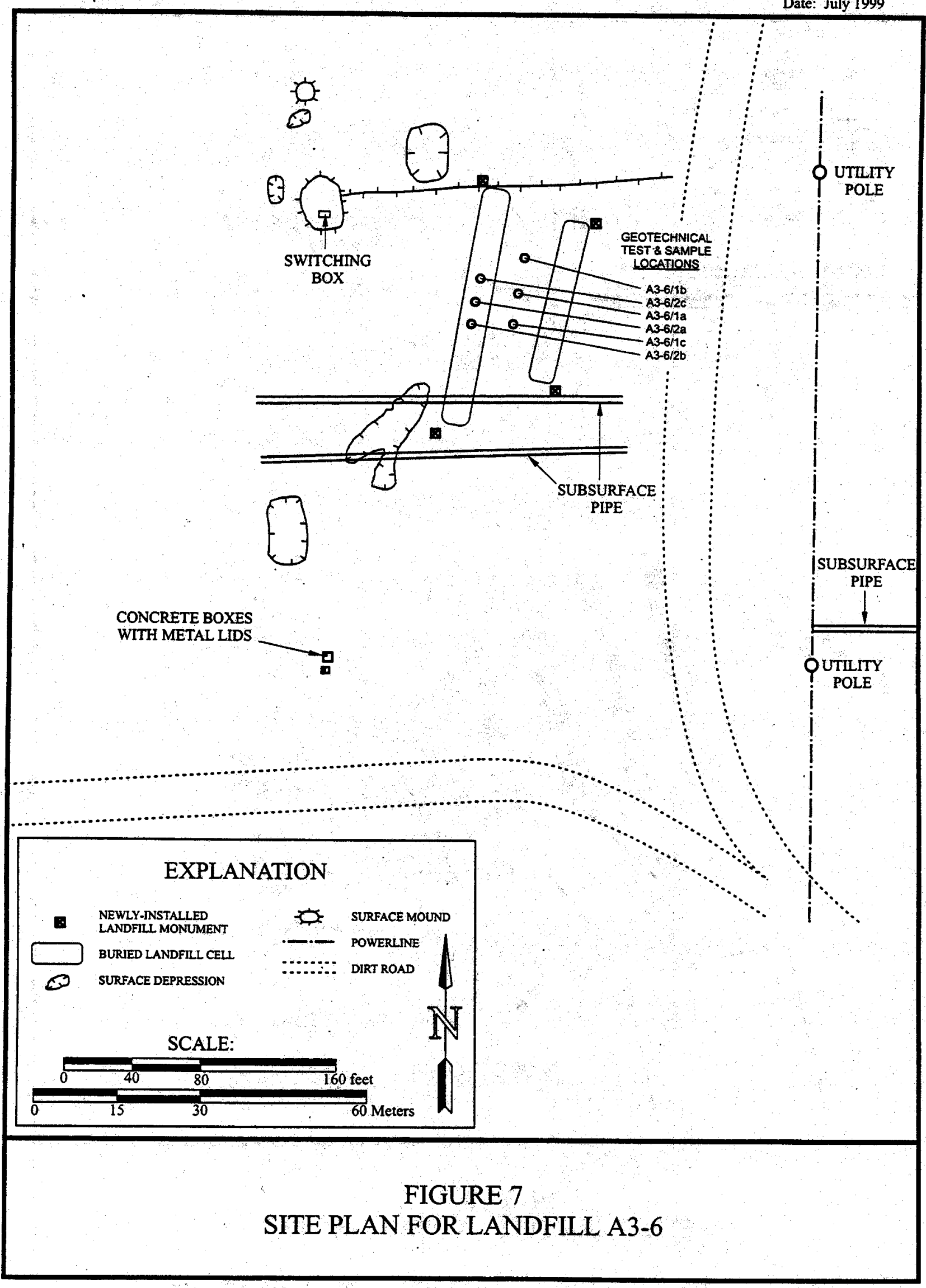




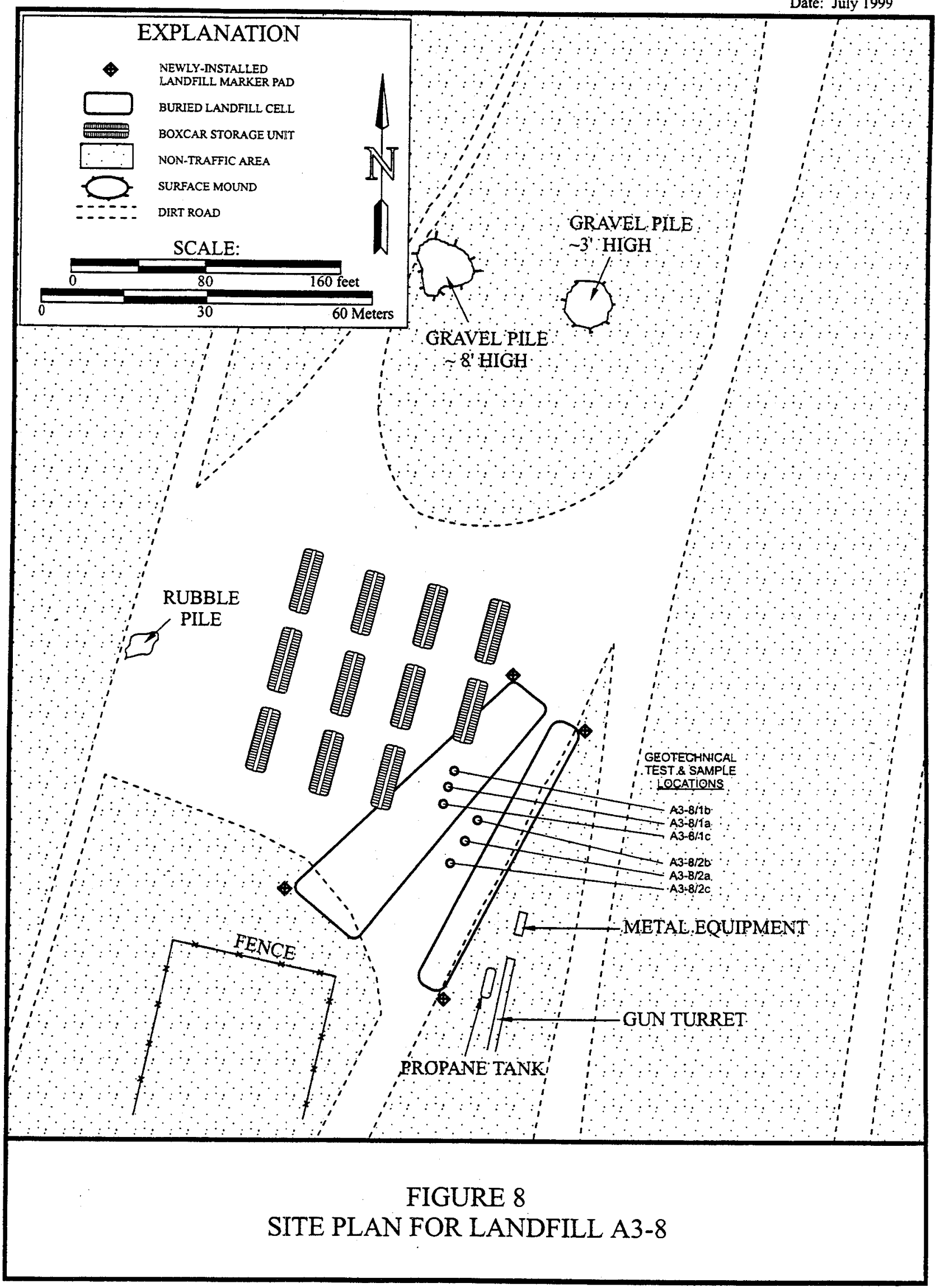


diesel storage tank, but the sinkhole was backfilled without further investigation. A second cell is no longer suspected to be a buried waste cell after no landfill debris or COCs were found in two other borings.

Landfill A3-3 consists of three buried waste cells (Figure 4). Landfill debris but no COCs were found in five of eight borings. A fourth cell is no longer suspected to be a buried waste cell after no landfill debris or COCs were found in one other boring.

Landfill A3-4 consists of two buried waste cells (Figure 5). Landfill debris but no COCs were found in seven of seven borings. Surface depressions and fissures were noted. A geophysical anomaly is no longer suspected to be a waste cell after no landfill debris or COCs were found in one other boring.

Landfill A3-5 consists of one buried waste cell (Figure 6). Landfill debris but no COCs were found in two of three borings.

Landfill A3-6 consists of two buried waste cells (Figure 7). Landfill debris but no COCs were found in all five borings.

Landfill A3-7 is no longer suspected to be a landfill after no landfill debris or COCs were found in one soil boring; therefore, a site plan is not provided.

Landfill A3-8 consists of two buried waste cells (Figure 8). Landfill debris but no COCs were found in four of six borings. The western cell is partially overlain by two railroad boxcars used for storage. The boxcars are situated over shallow excavations (to lower their floors closer to ground level) which were reported to intersect the western cell, exposing landfill wastes. A third buried cell and a buried pit are no longer suspected to be waste cells after no landfill debris or COCs were found in two other borings.

Conclusions provided in the CADD (DOE, 1998a) indicated that corrective actions were needed to protect human health and the environment but that the Area 3 Landfill Complex did not have to meet the requirements pertaining to Class III solid waste facilities.

\subsection{PURPOSE}

The purpose of this $C R$ is to:

- Document the closure activities and provide the information collected, as recommended in the CADD (DOE, 1998a) and proposed in the CAP (DOE, 1998b).

- Provide a Post-Closure Inspection Plan. 
- Obtain a Notice of Completion from the NDEP.

- Recommend the movement of CAU 424 from Appendix III to Appendix IV of the FFACO.

\subsection{SCOPE}

The following closure activities were implemented for CAU 424:

- Partial excavation of Landfill A3-2 to remove reported petroleum hydrocarbon wastes (Corrective Action Alternative 3).

- Existing soil covers were repaired and maintained (backfilled excavation and surface depressions, re-compact, and re-grade); permanent landfill markers and warning signs were installed; and administrative use restrictions were enacted for CAS Numbers: 03-80-001-A301, 03-80-002-A302, 03-80-002-A303, 03-80-002-A304, 03-80-002A305, 03-80-002-A306, and 03-80-002-A308 (Corrective Action Altemative 2).

- No action was performed at Landfill A3-7 CAS No. 03-80-002-A307 because the site is no longer believed to be a landfill (Corrective Action Alternative 1).

- Closure activities were coordinated with the USAF because of the location of the site and use restrictions.

- This CR documents remedial closure activities, provides a Post-Closure Inspection Plan, and proposes closure of CAU 424.

\subsection{CLOSURE REPORT CONTENTS}

This $\mathrm{CR}$ is divided into the following sections:

- Section 1.0 - Introduction: Site background, purpose, scope, and report contents

- Section 2.0 - Closure Activities: Corrective action activities, deviations from the CAP as approved, corrective action schedule as completed, and site plan

- Section 3.0 - Waste Disposition

- Section 4.0 - Closure Verification Results 
- Section 5.0 - Post-Closure Inspection Plan

- Section 6.0 - Summary, Conclusions, and Recommendations

- Section 7.0 - References

- Appendix A - Analytical Laboratory Report for Landfill A3-2 Closure

- Appendix B - As-Built Engineering Drawings

- Appendix C - Waste Disposal Documentation

- Appendix D - Geotechnical Test Results

- Appendix E - Use Restriction Documentation

- Appendix F - Post-Closure Inspection Checklist

- Appendix G - NDEP Closure Report Comment Response

This report was developed using information and guidance from the following documents:

- Corrective Action Investigation Plan For CAU No. 424. Area 3 Landfill Complex, Tonopah Test Range, Nevada, Revision 0, DOE/NV--476, DOE, 1997.

- Corrective Action Decision Document For The Area 3 Landfill Complex Tonopah Test Range, CAU 424, Revision 0, DOE/NV--496, DOE, 1998a.

- Corrective Action Plan For Corrective Action Unit 424: Area 3 Landfill Complex, Tonopah Test Range, Nevada, DOE/NV-11718--241, DOE, $1998 \mathrm{~b}$.

- Nevada Environmental Restoration Project, Health and Safety Plan, Revision 3, DOE, 1998.

- Nevada Environmental Restoration Project, Industrial Sites, Quality Assurance Project Plan, Nevada Test Site, Nevada, Revision 1, DOE/NV--372, DOE, 1996.

- Nevada Environmental Restoration Project, Project Management Plan, Revision 0, DOE, 1994. 


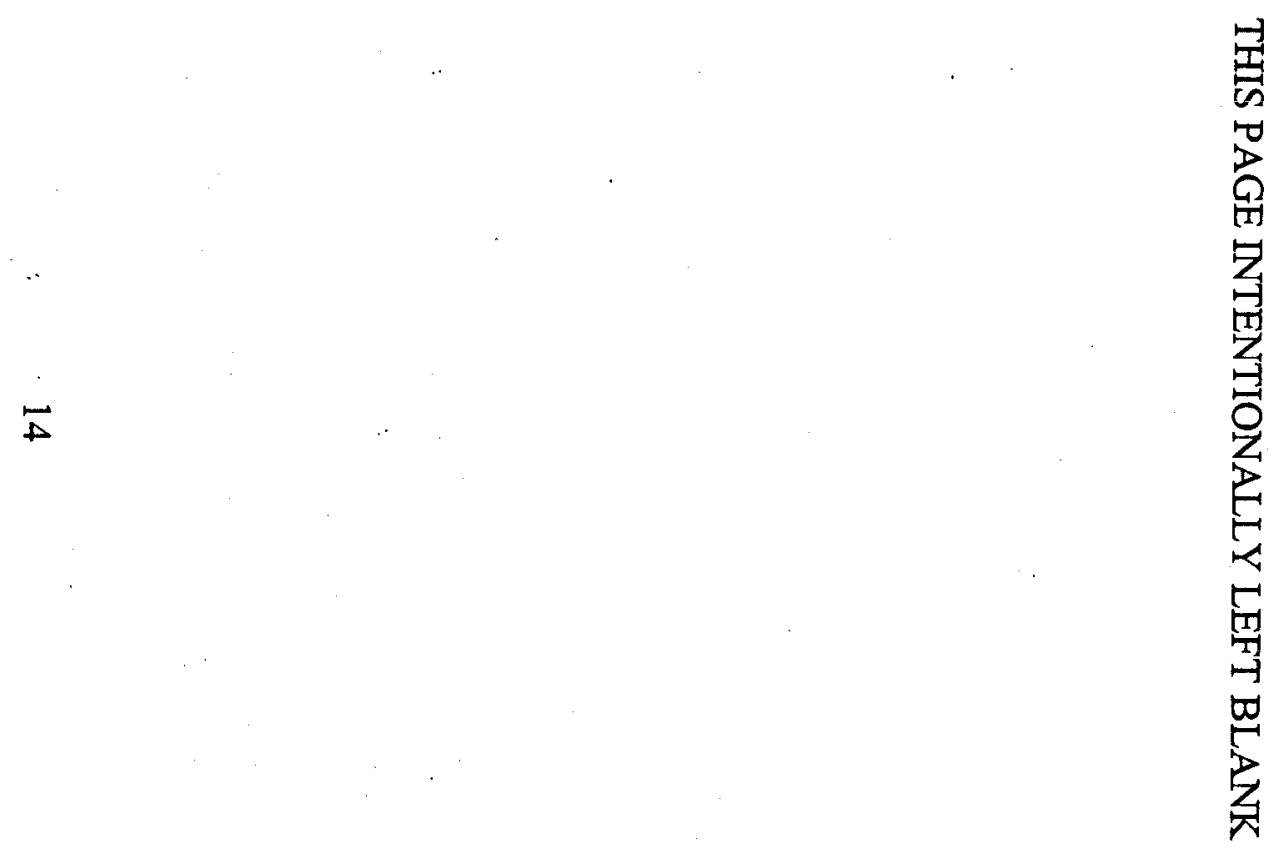




\subsection{CLOSURE ACTIVITIES}

This section of the CR details the specific activities involved in the closure of the Area 3 Landfill Complex CAU 424. This section also includes the rationale for deviations from the approved CAP (DOE, 1998b) and a detailed schedule of site activities as completed.

\subsection{DESCRIPTION OF CORRECTIVE ACTION ACTIVITIES}

Closure activities performed at the Area 3 Landfill Complex are summarized in Table 2 and include:

- Excavation and removal of petroleum hydrocarbon wastes.

- Repair and maintenance of landfill soil covers.

- Installation of landfill markers and warning signs.

- Enactment of administrative use controls.

\subsubsection{Petroleum Hydrocarbon-Impacted Wastes at Landfill A3-2}

\subsubsection{Investigation of Reported Buried Diesel Storage Tank}

The buried diesel storage tank reported in the CADD (DOE, 1998a) was visible through a small recently-formed sinkhole. Approximately $0.75 \mathrm{~m}(2.5 \mathrm{ft})$ of cover soil was removed with a backhoe on August 3,1998, and the tank was found to be an intact metal storage tank, with a horizontal axis aligned approximately north-south, with the north end approximately $2 \mathrm{~m}$ (7 ft) southeast of existing soil boring BH2-3 (Figure 3 ). The tank was approximately 3-m (10-ft) long, $1.5-\mathrm{m}(5-\mathrm{ft})$ wide, and filled with soil. There were no visual signs of impacted soil in the tank and field monitoring instruments indicated only background levels of organic vapors after an initial momentary peak of nine parts per million (ppm) on the photoionization detector and a maximum two percent lower explosive limit. The tank and its contents were re-buried with the same cover soil before beginning the sludge excavation. 
TABLE 2 - SUMMARY OF CLOSURE ACTIVITIES

\begin{tabular}{|c|c|c|c|c|c|}
\hline LANDFILL & $\begin{array}{c}\text { No } \\
\text { ACTION }\end{array}$ & $\begin{array}{c}\text { REMOVED } \\
\text { PETROLEUM } \\
\text { HYDROCARBON } \\
\text { WASTE } \\
\end{array}$ & $\begin{array}{l}\text { REPAIRED AND } \\
\text { MAINTAINED } \\
\text { LANDFILL SOIL } \\
\text { COVERS } \\
\end{array}$ & $\begin{array}{c}\text { INSTALLED } \\
\text { LANDFILL } \\
\text { MARKERS AND } \\
\text { SIGNS } \\
\end{array}$ & $\begin{array}{c}\text { ENACTED } \\
\text { ADMINISTRATIVE } \\
\text { USE } \\
\text { RESTRICTIONS } \\
\end{array}$ \\
\hline A3-1 & & & $x$ & $\mathbf{x}$ & $\mathrm{X}$ \\
\hline A3-2 & & $\mathrm{X}$ & $\mathrm{x}$ & $\mathbf{x}$ & $\bar{X}$ \\
\hline A3-3 & & & & $\mathbf{x}$ & $x$ \\
\hline A3-4 & & & $\mathrm{x}$ & $\mathrm{X}$ & $\bar{x}$ \\
\hline $\mathrm{A} 3-5$ & & & & $\mathbf{x}$ & $\mathrm{x}$ \\
\hline A3-6 & & & & $\bar{x}$ & $\mathbf{x}$ \\
\hline A3-7 & $\bar{x}$ & & & & \\
\hline A3-8 & & & $x$ & $\underline{X}$ & $\mathrm{X}$ \\
\hline
\end{tabular}




\subsubsection{Excavation of Reported Sludge-Impacted Area}

The excavation to remove sludge that was reported in the CADD (DOE, 1998a) began on August 3,1998, at the surface location of $\mathrm{BH} 2-3$ using a backhoe. Below approximately $0.6 \mathrm{~m}$ $(2 \mathrm{ft}$ ) of cover soil, the landfill was found to contain metal, reels of magnetic recording tape, foam rubber, rolls of rotted carpet, and pieces of heavy equipment. The loose, unconsolidated nature of the landfill necessitated that much of the debris exposed in the excavation be removed and that the excavation sidewalls be sloped sufficiently in order to minimize cave-in and maintain support for the backhoe. More-consolidated and debris-free native soil was observed beginning at a depth of approximately $2.4 \mathrm{~m}(8 \mathrm{ft})$.

Landfill wastes removed from the A3-2 sludge excavation were divided into two waste types. The first type consisted of approximately 15 cubic meters $\left(\mathrm{m}^{3}\right)\left(20\right.$ cubic yards $\left.\left[\mathrm{yd}^{3}\right]\right)$ of relatively unimpacted landfill debris and soil which were set aside in two plastic-lined and plastic-covered bulk waste piles. This waste tended to originate from shallower depths.

The second waste type consisted of suspected waste consisting of visually stained soil, and nine partially to completely crushed 55-gallon (gal) (208- liter [L]) drums. Several drums contained and leaked limited amounts of liquids or sludge (less than $10 \mathrm{gal}$ [38 L] total). A small amount of viscous gray liquid leaked from one crushed drum and a sample consisting of the puddle and impacted soil was collected and analyzed for TPH and volatile organic compounds (VOCs) (Sample ID: "Sludgel [solid]" [Table 3]). A watery brown mud spilled out of another crushed drum upon removal from the excavation. In this case, the mud was collected and analyzed for VOCs (Sample ID: "Sludge2 [aqueous]") and the soil near that drum, which contained some of the spilled mud, was sampled and analyzed for TPH, VOCs, semi-volatile organic compounds (SVOCs), and toxicity characteristic leachate procedure (TCLP) metals (Sample ID: "Sludge2 [solid]"). The crushed drums and potentially impacted soils were placed into seven new $208 \mathrm{~L}$ (55-gal) and four new $321 \mathrm{~L}$ (85-gal) steel drums. The analytical samples and results are discussed in Section 3.0 and the analytical laboratory report for Landfill A3-2 is included in Appendix A.

The bottom of the excavation was sampled to determine if the native soil contained petroleum hydrocarbons, and if TPH concentrations decreased with depth. Nine soil samples (Sludge3 through Sludge 11) were collected between approximate depths of $2.4 \mathrm{~m}(8 \mathrm{ft})$ and $3.7 \mathrm{~m}(12 \mathrm{ft})$. PetroFlag TPH field-screening tests and laboratory tests were performed. Collecting representative samples of native soil that was free of slumped landfill material from shallower depths, proved difficult. For this reason, the soil excavated from the bottom of the excavation were placed with the second waste group described in the preceding paragraph as a precaution. The results of TPH field tests and laboratory analyses are summarized in Table 3 and confirm that elevated TPH concentrations exist in the landfill, with the highest value in sample Sludge5 $(31,000 \mathrm{mg} / \mathrm{kg})$ from a depth of $2.7 \mathrm{~m}(9.0 \mathrm{ft})$. The non-detects in samples Sludge9 $(3.4 \mathrm{~m} \mathrm{[11}$

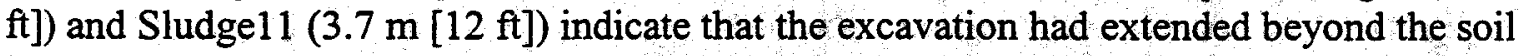
impacted above the TPH Regulatory Action Level. The excavation activities were halted after all 
TABLE 3 - SUMMARY OF FIELD AND LABORATORY TPH TESTS

\begin{tabular}{|c|c|c|c|c|c|}
\hline $\begin{array}{l}\text { SAMPLE } \\
\text { ID }\end{array}$ & $\begin{array}{l}\text { COLLECTION } \\
\text { DATE-TIME }\end{array}$ & $\begin{array}{c}\text { SAMPLE DEPTH } \\
m(f t)\end{array}$ & $\begin{array}{c}\text { FIELD PID } \\
\text { (HEADSPACE) } \\
\text { ppm } \\
\end{array}$ & $\begin{array}{c}\text { FIELD TEST KIT } \\
\text { (PETROFLAG) } \\
\mathrm{mg} / \mathrm{kg}\end{array}$ & $\begin{array}{c}\text { LABORATORY } \\
\text { (EPA 8015) } \\
\text { mg/kg } \\
\end{array}$ \\
\hline Sludge1 & $8 / 3 / 1998-1400$ & $1.8 \mathrm{~m}(6.0 \mathrm{ft})$ & - & - & 1,800 \\
\hline Sludge2 & $8 / 3 / 1998-1500$ & $2.1 \mathrm{~m}(7.0 \mathrm{ft})$ & - & - & 2,300 \\
\hline Sludge3 & $8 / 5 / 1998-1510$ & $2.4 \mathrm{~m}(8.0 \mathrm{ft})$ & - & 7217 & 4,800 \\
\hline Sludge4 & $8 / 5 / 1998-1525$ & $2.6 \mathrm{ft}(8.5 \mathrm{ft})$ & 15 & $>2000$ & $1,500(\mathrm{~J})$ \\
\hline Sludge5 & $8 / 5 / 1998-1610$ & $2.7 \mathrm{~m}(9.0 \mathrm{ft})$ & 28 & $>2000$ & $31,000(\mathrm{~J})$ \\
\hline Sludge6 & $8 / 5 / 1998-1635$ & $2.9 \mathrm{~m}(9.5 \mathrm{ft})$ & 2.0 & 167 & 580 \\
\hline Sludge7 & $8 / 5 / 1998-1645$ & $3.0 \mathrm{~m}(10 \mathrm{ft})$ & 15.8 & 8060 & $1,600(\mathrm{~J})$ \\
\hline Sludge $8^{\mathrm{a}}$ & $8 / 6 / 1998-1145$ & $3.4 \mathrm{~m}(11 \mathrm{ft})$ & 5.1 & 938 & $420(\mathrm{~J})$ \\
\hline Sludge $9^{b}$ & $8 / 6 / 1998-1145$ & $3.4 \mathrm{~m}(11 \mathrm{ft})$ & 5.1 & 938 & $\mathrm{ND}(<10)$ \\
\hline Sludge10 & $8 / 6 / 1998-1325$ & $3.5 \mathrm{~m}(11.5 \mathrm{ft})$ & 17 & $>2000$ & $1,400(\mathrm{~J})$ \\
\hline Sludge11 & $8 / 6 / 1998-1340$ & $3.7 \mathrm{~m}(12 \mathrm{ft})$ & 0.3 & 162 & $\mathrm{ND}(<10)$ \\
\hline
\end{tabular}

Notes:

PID - photo-ionization detector (the headspace field-screening method consisted of placing approximately $0.1 \mathrm{~kg}(0.2 \mathrm{lb})$ of soil into a sealed plastic bag for approximately 10 minutes in the sun and then analyzing the contained atmosphere for organic compounds with the PID)

ppm - part per million

$\mathrm{mg} / \mathrm{kg}$ - milligram per kilogram

TPH - total petroleum hydrocarbons, see Appendix A for laboratory report

(J) - laboratory estimated value due to probable matrix effects

ND - not detected (< detection limit)

a - matrix spike and matrix spike duplicates were taken for this sample

b - Sludge 9 is a duplicate sample of Sludge 8 and therefore has same field readings. 
visible containers (crushed drums) and suspected-impacted soils were removed from the excavation and the maximum extension of the backhoe was reached. Off-site disposal of all excavated soil and debris is described in Section 3. No wastes were returned to the excavation.

\subsubsection{Repair and Maintenance of Soil Covers}

Several of the landfill soil covers had surface depressions and fissures which could promote erosion of the soil cover as well as ponding and infiltration of surface water. The surface depressions at Landfills A3-1 (including A3-1a), A3-2 (including the sludge excavation), and A3-4 were backfilled with borrow material from the Sandia Borrow Pit. Borrow material was also placed as berms around two railcar storage units at Landfill A3-8 to prevent the potential inflow of surface water into trenches that intersect waste cells. A shallow diversion channel was constructed to divert surface water run-on around the Landfill A3-3 waste cells. The Sandia Borrow Pit is located less than $1 \mathrm{~km}(0.6 \mathrm{mi})$ east of the Area 3 Compound (see Figure 1 and Engineering Drawings in Appendix B for the location of the borrow pit). The volumes of borrow material and applied water reported below are approximate.

\subsubsection{Preparation and Conditioning of Borrow Material}

At the beginning of field closure activities, a soil sample was collected from the Sandia Borrow: Pit for geotechnical testing. The soil sample was collected to determine the maximum density (American Society for Testing and Materials [ASTM], 1997a [modified proctor test]) for compaction testing in backfilled areas. The results of geotechnical laboratory testing are discussed in Section 4.

Prior to placement of backfill, water was thoroughly mixed into the borrow material to control dust and to approximate the optimum moisture content for compaction purposes. Between July 20 and $24,1998,576,000$ L (152,000 gal) of water was used for this phase of soil preparation and dust control. Water for the closure activities was obtained from the Roller Coaster Well located approximately $8 \mathrm{~km}(5 \mathrm{mi})$ south of the Area 3 Compound (see Figure 1 and Engineering Drawings in Appendix B for the location of the well).

\subsubsection{Backfill of Surface Depressions}

Between July 27, 1998 and August 7, 1998, a total of $5,038 \mathrm{~m}^{3}\left(6,585 \mathrm{yd}^{3}\right)$ of conditioned borrow material was transported from the Sandia Borrow Pit, using two $11.5 \mathrm{~m}^{3}$ (15-yd $\left.\mathrm{d}^{3}\right)$ belly dump trucks, to Landfills $A 3-1 / A 3-1 a, A 3-2, A 3-4$, and A3-8, and placed as area backfill and grading material for the Area 3 Landfill Complex closure activities. Backfill of the Landfill A31 partially filled open cell and the Landfill A3-1a surface depression required a total of $4,923 \mathrm{~m}^{3}$ 
$\left(6,435 \mathrm{yd}^{3}\right)$ of borrow material. Landfill A3-2 surface depressions and sludge excavation required $46 \mathrm{~m}^{3}\left(60 \mathrm{yd}^{3}\right)$ of borrow material which was temporarily stockpiled adjacent to the landfill until placed and compacted on August 12, 1998. Landfill A3-4 required $46 \mathrm{~m}^{3}\left(60 \mathrm{yd}^{3}\right)$ of borrow material to backfill surface depressions to grade. The placement of soil berms around two railcar storage units at Landfill $\mathrm{A} 3-8$ required $23 \mathrm{~m}^{3}\left(30 \mathrm{yd}^{3}\right)$ of borrow material. During placement of backfill, 1,516,000 L ( 400,000 gal) of water were used for dust control, soil conditioning, and compaction over the backfilled areas.

A loader/backhoe was used to distribute and compact the borrow material at each site requiring backfill. The backfill at Landfill A3-1/A3-1a was further compacted by the repeated passes of the water truck and belly dump trucks. The borrow material was placed in lifts of $0.2 \mathrm{~m}$ ( 8 inch [in]) except for the initial lifts in Landfill A3-1/A3-1a. In the partially filled open cell of Landfill A3-1, the presence of large, irregularly shaped pieces of concrete and asphalt construction rubble precluded compaction until several feet or more of backfill were placed in certain locations. In the A3-1 a surface depression, the initial lifts of backfill varied in thickness due to the bowlshaped bottom. Landfill A3-2 surface depressions and sludge excavation were backfilled on August 12, 1998. Backfill in the 3.7-m (12-ft) deep sludge excavation was placed in 0.2-m (8-in) lifts and compacted with downward blows from the backhoe bucket until the backfill reached a level close enough to the ground surface that compaction could be accomplished by being driven over by the backhoe. The berms at Landfill A3-8 were constructed using a combination of loader/backhoe and manual labor, and were not tested for compaction. The field performance specification for compaction of backfill and the results of compaction verification tests at Landfills A3-1/A3-1a, A3-2, and A3-4 are discussed in Section 4.2.

\subsubsection{Installation of Markers and Warning Signs}

The landfill boundaries in the Area 3 Landfill Complex were marked with monuments in lowtraffic areas and with pads at grade in high-traffic areas. The monuments and pads were both constructed with rebar-reinforced concrete for durability and embedded with brass survey markers. The monuments are truncated pyramids approximately $1.8 \mathrm{~m}(6 \mathrm{ft})$ high with a square

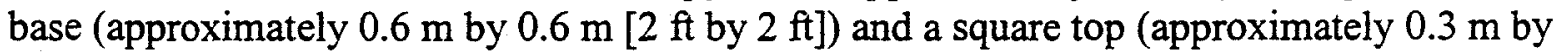
$0.3 \mathrm{~m} \mathrm{[1} \mathrm{ft} \mathrm{by} 1 \mathrm{ft}]$ ). In most cases, monuments are buried approximately $0.3 \mathrm{~m}(1 \mathrm{ft})$, leaving the top approximately $1.5 \mathrm{~m}(5 \mathrm{ft})$ above the ground surface. The pads at grade are roughly 0.6 $\mathrm{m}$ by $0.6 \mathrm{~m} \mathrm{(} 2 \mathrm{ft}$ by $2 \mathrm{ft})$ square and $0.3 \mathrm{~m}(1 \mathrm{ft})$ deep. Warning signs were affixed to the monuments and the same message was stamped on the brass markers which were embedded into the pads. The warning messages read:

Warning, buried wastes. Before disturbing ground surface, contact Security 295-8285. FFACO CAU 424, Area 3 Landfill Complex, Landfill [identification number]. 


\subsection{DEVIATIONS FROM CORRECTIVE ACTION PLAN AS APPROVED}

No deviations from the approved CAP (DOE, 1998b) occurred.

\subsection{CORRECTIVE ACTION SCHEDULE AS COMPLETED}

The corrective action activities were completed in a timely manner. A schedule of the project activities as completed can be found in Figure 9.

\subsection{SITE PLAN/SURVEY PLAT}

As-built engineering drawings are included in Appendix B and indicate that the soil covers over the waste cells are flat to slightly sloped, with minimal potential for ponding. The field work included construction of a shallow drainage channel along the upslope sides of the Landfill A3-3 waste cells, diverting sheetwash run-on around that landfill. The topography in the vicinity of CAU 424 is shown in Figure 10 and demonstrates that the Area 3 Landfill Complex is located in an area slightly sloped to the northeast and is not located in a low-lying area where significant ponding or channeling of surface water is likely. The CAU 424 area has been modified since the map was produced but no significant change to the drainage pattern was noted. 


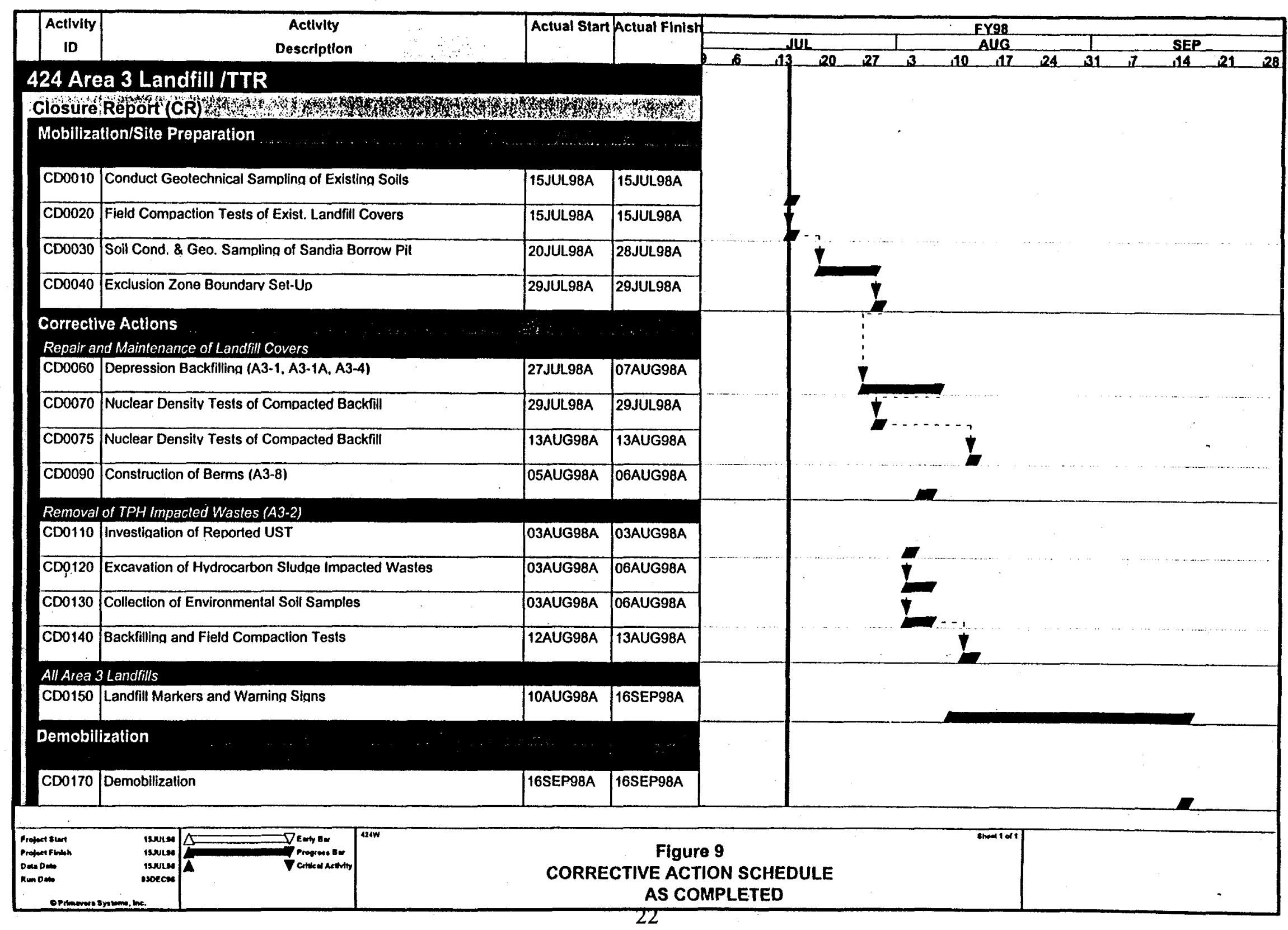




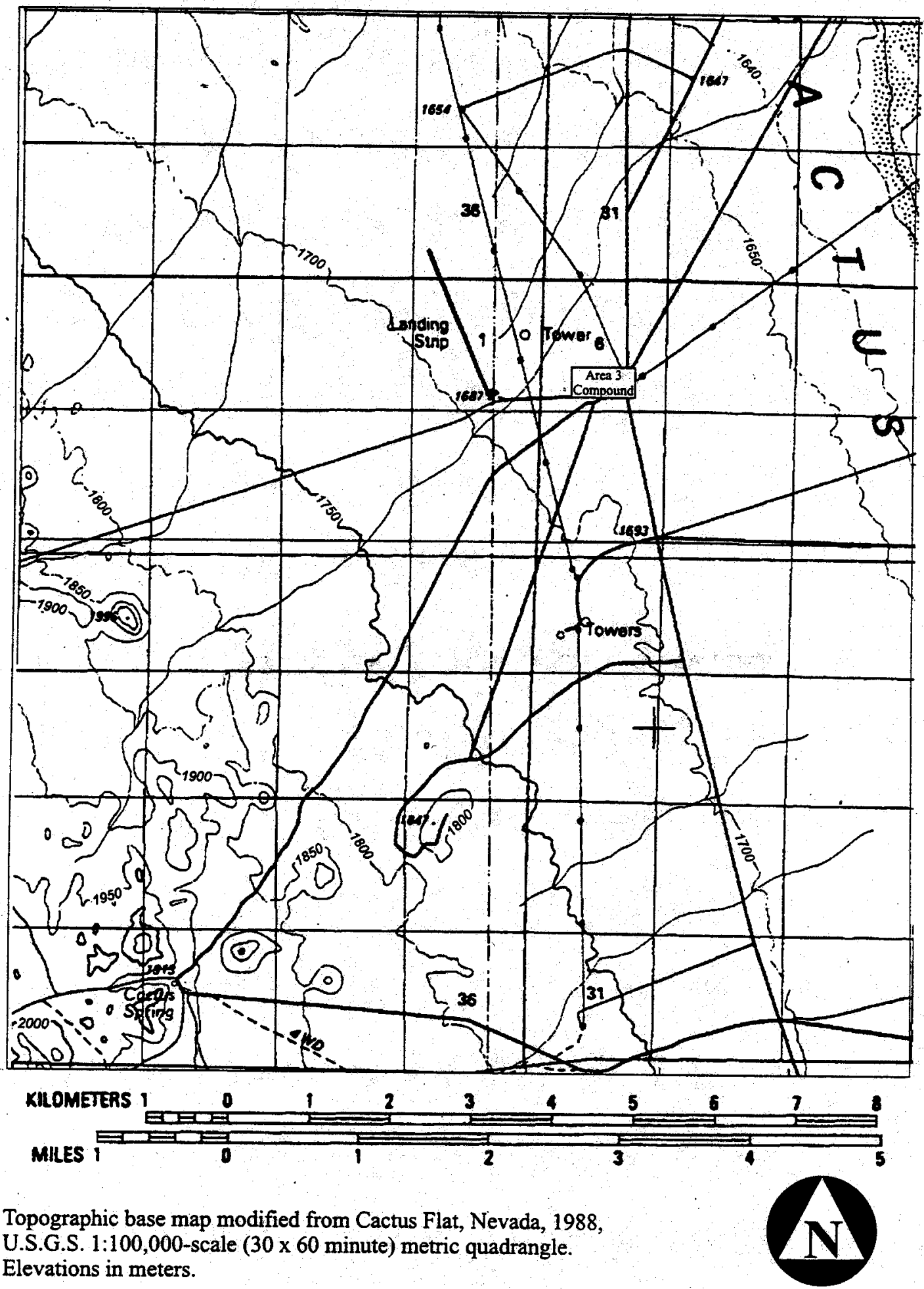

Elevations in meters.

FIGURE 10

\section{TOPOGRAPHY IN THE VICINITY OF THE AREA 3 LANDFILL COMPLEX}


THIS PAGE INTENTIONALLY LEFT BLANK 


\subsection{WASTE DISPOSITION}

Based on available process knowledge, the waste inventory described in the CAIP (DOE, 1997), and analytical results in the CADD (DOE, 1998a), only petroleum hydrocarbon waste was expected in Landfill A3-2. None of the Area 3 Landfills are active and approved disposal facilities. Therefore, landfill wastes that were removed from the Landfill A3-2 sludge excavation were not returned to the excavation. As described in Section 2.1.2, landfill soil and debris removed from the excavation were segregated and stored as two waste types. The first waste type consisted of approximately $15 \mathrm{~m}^{3}\left(20 \mathrm{yd}^{3}\right)$ of the most shallow excavated landfill soil and debris which did not exhibit visual signs (such as staining or labeled containers) or elevated field instrumentation readings (photo-ionization and lower explosive limit) that would have indicated potential impact by petroleum hydrocarbon wastes. Landfill debris included materials such as carpeting, magnetic recording tape, electronic cable, and scrap metal. This waste was temporarily stored and covered with plastic as two bulk waste piles. The waste piles were assigned waste tracking No. BN0450. Based on the waste characterization in the CADD (DOE, 1998a), the waste piles were transported in covered end-dump trucks to an approved disposal facility (Landfill U10C at the NTS) on September 16, 1998.

The second waste type consisted of deeper landfill soil and debris suspected or observed to include liquid and sludge. These wastes were sampled for TPH, VOCs, SVOCs, and TCLP metals, then placed into 11 drums and held in a 90-day accumulation area. Analytical results are summarized in Table 4.

A number of VOCs (Acetone at 82 micrograms per kilogram [ $\mu \mathrm{g} / \mathrm{kg}$ ], 2-Butanone at $26 \mu \mathrm{g} / \mathrm{kg}$, n-Propylbenzene at $6 \mu \mathrm{g} / \mathrm{kg}, 1,2,4-$ Trimethylbenzene at $24 \mu \mathrm{g} / \mathrm{kg}, 1,3,5$-Trimethylbenzene at $9 \mu \mathrm{g} / \mathrm{kg}, o-X y l e n e$ at $6 \mu \mathrm{g} / \mathrm{kg}$, and $\mathrm{m}, \mathrm{p}-X y l e n e$ at $9 \mu \mathrm{g} / \mathrm{kg}$ ) were reported in one sample ("Sludgel"), but the results are not indicative of being RCRA-hazardous because of the low concentrations and lack of specific process information indicating these VOCs were disposed. Concentrations of SVOCs and TCLP metals were low to non-detectable. Therefore, the waste was characterized as containing only petroleum hydrocarbons (and non-RCRA-hazardous). The waste was assigned waste tracking No. BN0453 and transported to an approved disposal facility (Landfill U10C at the NTS) as petroleum-hydrocarbon waste on December 9, 1998. These wastes included decontamination rinsate, plastic sheeting, and personnel protective equipment. Waste disposal documentation is provided in Appendix C. 
TABLE 4 - SUMMARY OF 1998 ANALYTICAL RESULTS

\begin{tabular}{|c|c|c|}
\hline $\begin{array}{c}\text { ANALYSES } \\
\text { PERFORMED AND } \\
\text { ANALYTES DETECTED } \\
\end{array}$ & $\begin{array}{c}\text { CONCENTRATION } \\
\text { REPORTED } \\
\text { (unless otherwise noted) } \\
\end{array}$ & $\begin{array}{c}1998 \text { EPA PRGs } \\
\text { RESIDENTIAL / INDUSTRIAL } \\
\text { (unless otherwise noted) } \\
\end{array}$ \\
\hline $\begin{array}{l}\text { SLUDGE1 (solid) } \\
\text { Total Petroleum } \\
\text { Hydrocarbons } \\
\text { Oil Range Organics } \\
\\
\text { Volatile Organic } \\
\text { Compounds } \\
\text { Acetone } \\
\text { 2-Butanone } \\
\text { n-Propylbenzene } \\
\text { 1,2,4-Trimethylbenzene } \\
\text { 1,3,5-Trimethylbenzene } \\
\text { o-Xylene } \\
\text { m,p-Xylene }\end{array}$ & $\begin{array}{c}1,800 \mathrm{mg} / \mathrm{kg} \\
\\
82 \mathrm{ug} / \mathrm{kg} \\
26 \mathrm{ug} / \mathrm{kg} \\
6 \mathrm{ug} / \mathrm{kg}(J) \\
24 \mathrm{ug} / \mathrm{kg}(J) \\
9 \mathrm{ug} / \mathrm{kg}(J) \\
6 \mathrm{ug} / \mathrm{kg}(J) \\
9 \mathrm{ug} / \mathrm{kg}(J)\end{array}$ & $\begin{array}{c}100 \mathrm{mg} / \mathrm{kg} \text { (see note } 1) \\
\\
1,400,000 / 6,100,000 \mathrm{ug} / \mathrm{kg} \\
6,900,000 / 27,000,000 \mathrm{ug} / \mathrm{kg} \\
130,000 / 550,000 \mathrm{ug} / \mathrm{kg} \\
51,000 / 170,000 \mathrm{ug} / \mathrm{kg} \\
21,000 / 70,000 \mathrm{ug} / \mathrm{kg} \\
280,000 / 280,000 \mathrm{ug} / \mathrm{kg} \\
210,000 / 210,000 \mathrm{ug} / \mathrm{kg} \\
\text { (see note } 2 \text { ) } \\
\end{array}$ \\
\hline $\begin{array}{l}\text { SLUDGE2 (solid) } \\
\text { Total Petroleum } \\
\text { Hydrocarbons } \\
\text { Oil Range Organics } \\
\text { Volatile Organic } \\
\text { Compounds } \\
\text { none detected } \\
\text { Semi-Volatile Organic } \\
\text { Compounds } \\
\text { none detected } \\
\text { TCLPMetáls } \\
\text { Chromium }\end{array}$ & $\begin{array}{l}2,300 \mathrm{mg} / \mathrm{kg} \\
\text { nd } \\
\text { nd } \\
0.091 \mathrm{mg} / \mathrm{L}\end{array}$ & $\begin{array}{c}\text { na / na } \\
\text { na / na } \\
5.0 \mathrm{mg} / \mathrm{L} \text { (see note } 3)\end{array}$ \\
\hline
\end{tabular}


TABLE 4 - SUMMARY OF 1998 ANALYTICAL RESULTS (Continued)

\begin{tabular}{|l|c|c|}
\hline $\begin{array}{c}\text { ANALYSES } \\
\text { PERFORMED AND } \\
\text { ANALYTES DETECTED }\end{array}$ & $\begin{array}{c}\text { CONCENTRATION } \\
\text { REPORTED } \\
\text { (unless otherwise noted) }\end{array}$ & $\begin{array}{c}\text { 1998 EPA PRGs } \\
\text { RESIDENTIAL / INDUSTRIAL } \\
\text { (ug/kg unless otherwise noted) }\end{array}$ \\
\hline $\begin{array}{l}\text { SLUDGE2 (aqueous) } \\
\text { Volatile Organic } \\
\text { Compounds } \\
\text { none detected }\end{array}$ & nd & \\
\hline
\end{tabular}

\section{Notes:}

Total Petroleum Hydrocarbons (TPH), EPA Method 8015

Volatile Organic Compounds (VOCs), EPA SW846, Method 8260B

Semi-Volatile Organic Compounds (SVOCs) by EPA $8270 \mathrm{C}$

Toxicity Characteristic Lechate Potential (TCLP) Metals, EPA 6010A (7470A for Mercury)

PRG - Preliminary Remediation Goal

Note 1 - NDEP Regulatory Action Level for TPH

Note 2 - There are separate EPA PRGs for $m$-Xylene and $p$-Xylene. PRG for $m$-xylene is lower and used here

Note 3- EPA Regulatory Level for chromium toxicity characteristic

ug/kg - microgram per kilogram

$\mathrm{mg} / \mathrm{kg}$ - milligram per kilogram

ug/L - microgram per liter

nd - not detected

na - not applicable

J - laboratory estimated value due to probable matrix effects

See Appendix A for analytical laboratory report 
THIS PAGE INTENTIONALLY LEFT BLANK 


\subsection{CLOSURE VERIFICATION RESULTS}

\subsection{GEOTECHNICAL TESTING OF EXISTING SOILS}

In order to characterize the geotechnical site conditions and potential borrow materials, the following soil samples were collected prior to, or at the beginning of, area-filling and grading activities: 12 soil samples of existing landfill covers and adjacent disturbed and undisturbed areas; and 1 soil sample of the Sandia Borrow Pit material. These soil samples were submitted to the Bechtel Nevada Materials Testing Laboratory for Proctor (maximum) density tests (ASTM, 1997a), sieve analyses (ASTM, 1997b), and permeability tests (ASTM, 1997c). In addition, 43 nuclear density tests (ASTM, 1997d) were done at 15 locations on existing landfill covers and adjacent disturbed and undisturbed areas, to determine the field compaction of existing soils. Field test and sample collection locations are shown in Figures 3 through 8 . Test results were reported in the geotechnical laboratory report (Appendix D) and are summarized with comparable data from the CADD (DOE, 1998a) in Table 5.

For native and existing landfill cover soils, maximum densities ranged from 1,956 to 2,075 kilograms per cubic meter $\left(\mathrm{kg} / \mathrm{m}^{3}\right)\left(122.1\right.$ to 129.5 pounds per cubic foot $\left.\left[\mathrm{lb} / \mathrm{ft}^{3}\right]\right)$, field compaction ranged from 73.7 to 97.9 percent maximum density, and permeabilities of samples remolded to field conditions ranged from $1.28 \times 10^{-6}$ to $3.43 \times 10^{-3}$ centimeters per second $(\mathrm{cm} / \mathrm{sec})$.

For the Sandia Borrow Pit material, maximum density was $2,035 \mathrm{~kg} / \mathrm{m}^{3}\left(127.0 \mathrm{lb} / \mathrm{ft}^{3}\right)$ with permeabilities of $8.82 \times 10^{-4}, 3.80 \times 10^{-5}$, and $1.39 \times 10^{-5} \mathrm{~cm} / \mathrm{sec}$ after recompaction to 85,90 , and 95 percent maximum density, respectively. Sieve analyses confirmed that the borrow material was similar to existing site soils (silty sand with gravel) and that size reduction of the borrow material was not required before use.

The geotechnical results shown in Table 5 reveal comparable degrees of field compaction for existing landfill covers and adjacent native soils (disturbed and undisturbed), indicating that subsidence due to consolidation of the landfill covers is unlikely. Except for Landfill A3-3, the permeabilities of existing landfill covers are less than, or comparable to, the permeabilities of adjacent native soils, indicating that preferential infiltration over the waste cells is unlikely. For Landfill A3-3, the existing cover was determined to be more permeable $\left(4.51 \times 10^{-5}\right.$ to $3.43 \times 10^{-3}$ $\mathrm{cm} / \mathrm{sec})$ than the adjacent native soil $\left(5.32 \times 10^{-6}\right.$ to $\left.6.24 \times 10^{-6} \mathrm{~cm} / \mathrm{sec}\right)$. The potential for preferential infiltration at Landfill A3-3 was minimized with the construction of a shallow drainage channel that diverts surface water that would otherwise run onto the Landfill A3-3 waste cells. The location of the diversion channel is shown in Figure 4 and in Appendix B, Most of the precipitation that falls directly onto the existing landfill covers, including the Landfill A3-3 cover, is expected either to run off due to the gently-sloping surfaces, or to evaporate due to the generally arid climate. 
TABLE 5 - SUMMARY OF GEOTECHNICAL TESTS

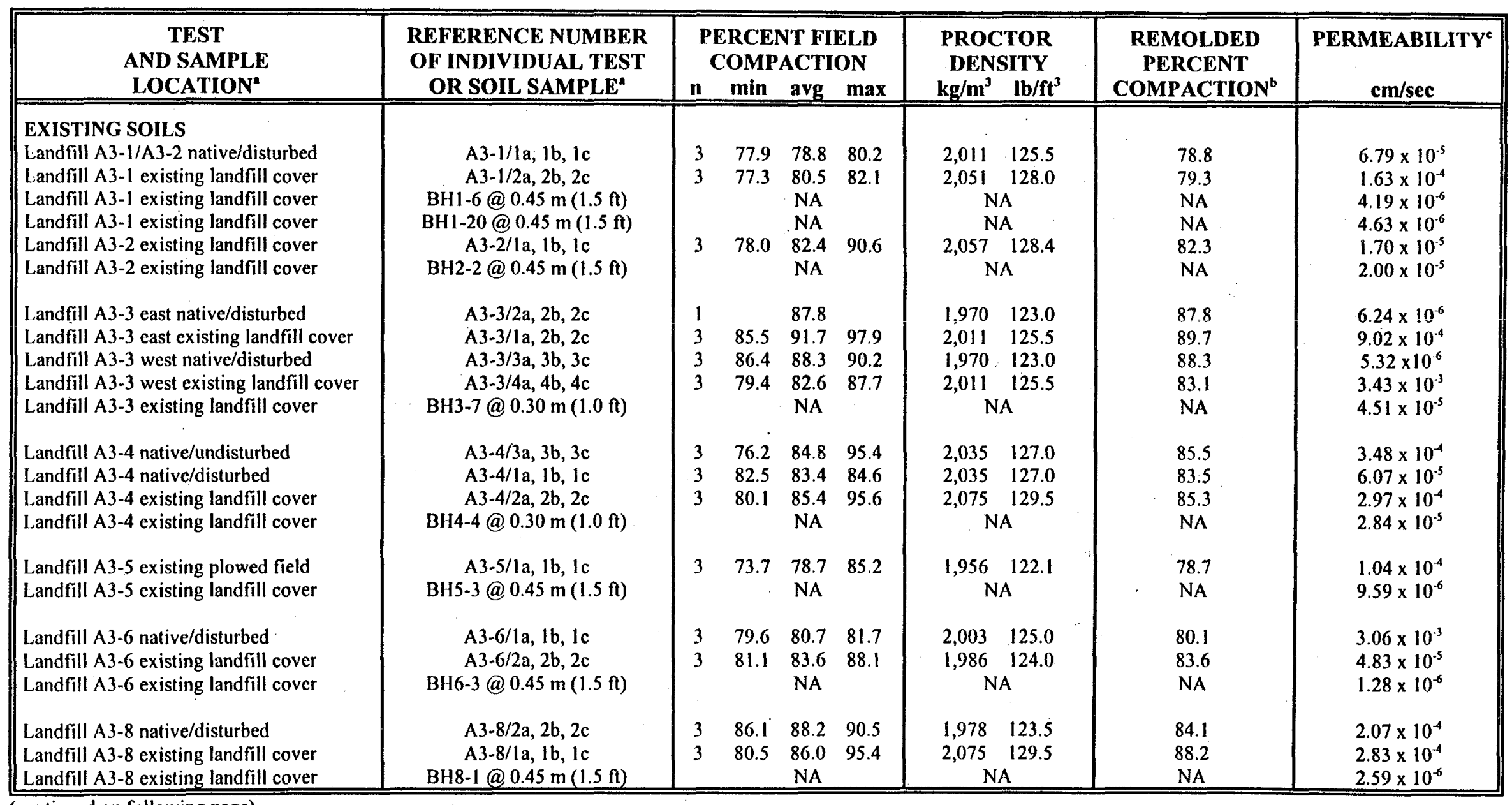

(continued on following page) 


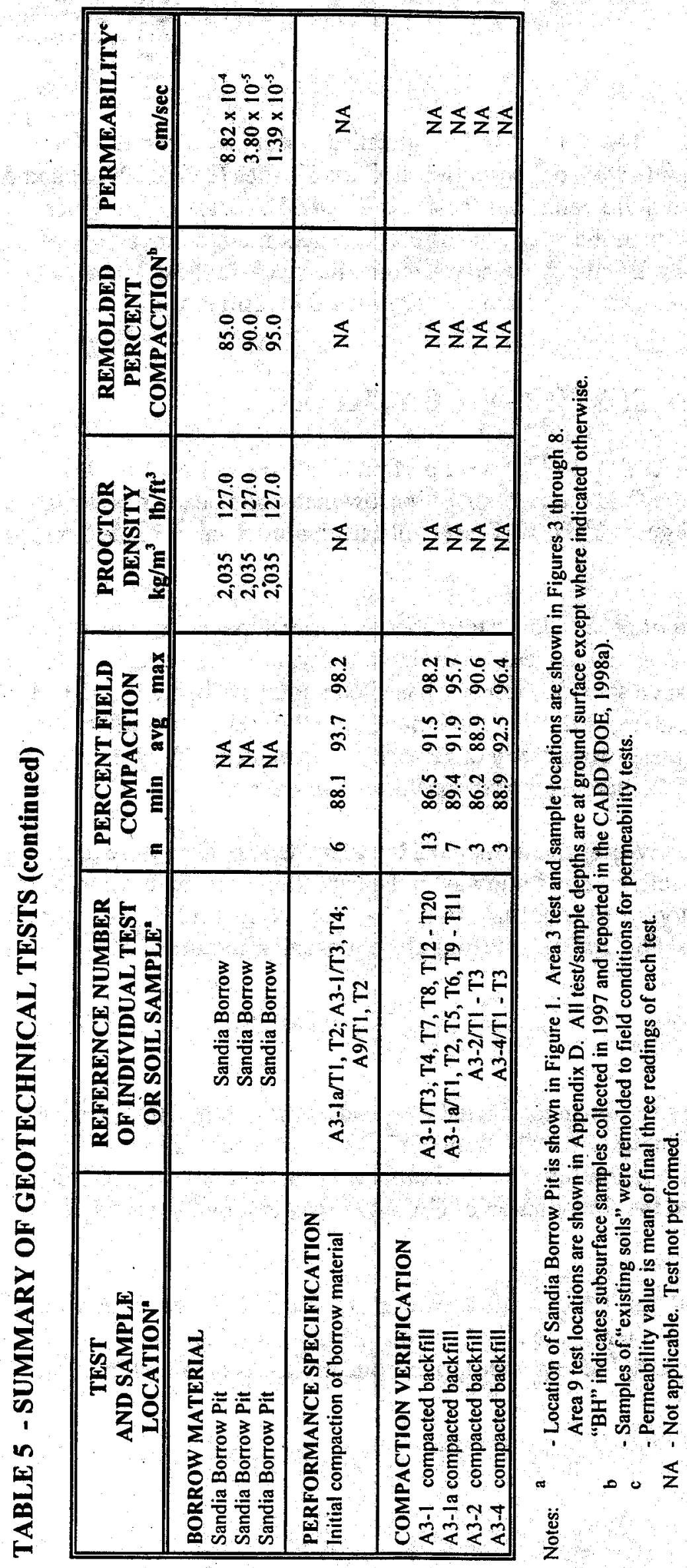


Nevada Administrative Code (NAC) 444.731 to 444.747 specifies closure requirements for a Class III landfill. The Area 3 landfills were not permitted as Class III sites (DOE, 1998a) and do not need to meet Class III closure requirements, but the Class III landfill closure requirements were used as guidance for the closure of the Area 3 landfills. The maximum permeability of $1 \times 10^{-5} \mathrm{~cm} / \mathrm{sec}$ allowable for a Class III site in Nevada Administrative Code (NAC) 444.743, was exceeded by eleven of the sixteen samples from existing Area 3 landfill covers.

\subsection{FIELD COMPACTION TESTING OF BACKFILL}

A total of 26 nuclear density tests (ASTM, 1997d) were performed at Area 3 Landfills A3-1, A31a, A3-2, and A3-4, to determine the field compaction of borrow material placed as backfill. Field test locations are shown in Figures 3 and 5. Test results are summarized in Table 5 and in Appendix D.

At the beginning of backfilling activities, a field performance specification was established to facilitate backfill compaction to at least 80 percent maximum density, as required in the CAP (DOE, 1998b). The field performance specification was based on a total of six nuclear density tests (two each at Landfills A3-1, A3-1a, and A9-1) performed on 0.2-m (8-in) lifts after being compacted by one complete pass (once forward and once back) of the loader. The percent compaction ranged from 88.1 to 98.2 , meeting the compaction requirement.

During and following backfilling activities, an additional 22 nuclear density tests were done on compacted backfill to verify compaction in lifts midway in the backfilling operation (Landfills A3-1 and A3-1a), and in the final top lifts (Landfills A3-1, A3-1a, A3-2, and A3-4). The percent compaction of backfill ranged from 86.2 to 98.2 , meeting the compaction requirement.

\subsection{USE RESTRICTIONS}

Closure activities conducted at the site were coordinated with and acknowledged by the USAF (Appendix E). The Acknowledgment of CAU 424 from the USAF was received by the DOE/NV on July 15,1998 , the CAU Use Restriction Information Forms were submitted by the DOE/NV to the USAF on April 29, 1999, and the Recordation of CAU 424 was sent by the USAF to the DOE/NV on July 1, 1999.

The future use of any land related to this CAU, as described in Appendix E, is restricted from any DOE or USAF activity that may alter or modify the containment control as identified in this $\mathrm{CR}$ or other documentation for this CAU unless appropriate concurrence is obtained in advance. 


\subsection{POST-CLOSURE INSPECTION PLAN}

Post-closure inspection of the Area 3 Landfill sites is intended to determine:

- If maintenance and repairs to the landfill soil covers are needed.

- If maintenance and repairs to the landfill markers and waming signs are needed.

- If modifications to the use restriction administrative controls are needed.

- If termination of post-closure inspection can be proposed in the future.

\subsection{POST-CLOSURE INSPECTION}

The inspection will consist of biannual (twice per year) visual inspections of:

- The soil cover for indications of subsidence, erosion, unauthorized use, etc.

- The landfill markers and warning signs to verify they are in-place, intact, and readable.

- The inspections will be documented on a checklist (Appendix F) and with photography, if needed.

If damage to the soil covers, landfill markers, or warning signs is noted, then maintenance will be performed and may include placement and compaction of additional backfill, and repair or replacement of markers and signs. Additional, nonscheduled inspections may be required after severe weather events such as heavy rainfall, flash flooding, and high winds. Any identified maintenance and repair requirements will be remedied within 90 days of discovery and documented in writing at the time of repair.

\subsection{ANNUAL REPORTING}

An annual report will be prepared that will provide the observations and describe modifications and/or repairs made to the cover and cover area. The annual post-closure inspection report will be prepared and submitted to NDEP following the second inspection of each year that postclosure inspection is conducted. The annual reports will include the following information:

- Discussion of observations.

- Inspection checklist (Appendix F) and maintenance record.

- Conclusions and recommendations. 


\subsection{DURATION}

The biannual inspections will be performed for five years after the completion of closure activities, and will be documented on inspection forms.

Completion of post-closure inspection of CAU 424 may be proposed by DOE/NV to the NDEP after two consecutive years of visual inspections have not indicated the recurrence of subsidence. Completion of post-closure inspection may be proposed by DOE/NV to the NDEP within five years after the completion of closure activities. 


\subsection{SUMMARY, CONCLUSIONS AND RECOMMENDATIONS}

\subsection{SUMMARY AND CONCLUSIONS}

The following summary and conclusions are based on the completed site closure activities and information provided in this report:

- The petroleum hydrocarbon sludge and sludge-impacted wastes that exceeded the TPH Regulatory Action Level of $100 \mathrm{mg} / \mathrm{kg}$ were removed from Landfill A3-2 and transported to approved landfills at the NTS.

- The Landfill A3-2 sludge excavation and surface depressions at Landfills A3-1, A3-1a, A3-2, and A3-4 were backfilled with soil from the Sandia Borrow Pit. Compaction results complied with the compaction requirement of at least 80 percent of the maximum density.

- Borrow soil berms were placed around the bases of two railroad box cars used for storage at Landfill A3-8 in order to minimize inflow of surface water. A shallow drainage channel was constructed on the upslope side of Landfill A3-3 to divert surface water run-on.

- Markers and signs were installed to document landfill locations and warn of buried wastes.

- Closure activities have been coordinated with the USAF.

- The CAU Use Restriction Information Forms were submitted to the USAF on April 29, 1999, for recordation. On July 1,1999 , the Recordation of CAU 424 was returned to the DOE/NV.

- The field closure activities conducted at the site were completed in accordance to the approved CAP (DOE, 1998b).

\subsection{RECOMMENDATIONS}

Since the closure activities for CAU 424 have been completed in accordance with the NDEPapproved CAP (DOE, 1998b) as documented in this CR, the DOE/NV requests:

- A Notice of Completion be provided by the NDEP to DOE/NV for the closure of CAU 424 (CAS Numbers 03-08-001-A301 and 03-08-002-A302 through A308).

- CAU 424 be moved from Appendix III to Appendix IV of the FFACO.

- DOE/NV will continue to perform post-closure inspection of the site as indicated in Section 5.0 of this $\mathrm{CR}$. 
THIS PAGE INTENTIONALLY LEFT BLANK 


\subsection{REFERENCES}

American Society for Testing and Materials, see ASTM

ASTM, 1997a. Method D 1557-91: Test Method for Laboratory Compaction Characteristics of Soil Using Modified Effort, 1997Annual Book of ASTM Standards, Volume 04.08, Soil and Rock (I): D 420 - D 4914.

ASTM, 1997b. Method D 422-63 (Reapproved 1990): Standard Test Method for Particle-Size Analysis of Soils, and Method D 1 140-92: Standard Test Method for Amount of Material in Soils Finer Than the No. 200 Sieve, 1997 Annual Book of ASTM Standards, Volume 04.08, Soil and Rock (I): D 420 - D 4914.

ASTM, 1997c. Method D 2434-68 (Reapproved 1974): Standard Test Method for Permeability of Granular Soils (Constant Head), 1997 Annual Book of ASTM Standards, Volume 04.08, Soil and Rock (I): D 420 - D 4914.

ASTM, 1997d. Method D 2922-96: Standard Test Methods for Density of Soil and SoilAggregate in Place by Nuclear Methods (Shallow Depth), 1997 Annual Book of ASTM. Standards, Volume 04.08, Soil and Rock (I): D 420 - D 4914.

DOE, 1994. Nevada Environmental Restoration Project, Project Management Plan, Rev. 0.

DOE, 1996. Nevada Environmental Restoration Project, Industrial Sites, Quality Assurance Project Plan, Nevada Test Site, Rev. 1, DOE/NV-372.

DOE, 1997. Corrective Action Investigation Plan for CAUNo, 424: Area 3 Landfill Complex, Tonopah Test Range, Nevada, Rev. 0, April 1997, DOE/NV-476 UC-700.

DOE, 1998a. Corrective Action Decision Document for the Area 3 Landfill Complex, Tonopah Test Range, CAU 424, Rev. 0, March 1998, DOE/NV--496 UC-700.

DOE, 1998b. Corrective Action Plan for Corrective Action Unit 424: Area 3 Landfill Complex, Tonopah Test Range, Nevada, August 1998, DOE/NV-11718-241 UC-702.

DOE, 1998c. Nevada Environmental Restoration Project, Health and Safety Plan, Rev. 3.

EPA, 1998. Region IX Preliminary Remediation Goals (PRGs), San Francisco, CA.

Federal Facilities Agreement and Consent Order, see FFACO

FFACO, 1996, Agreed to by the Nevada Division of Environmental Protection, the U.S.

Department of Energy, and the U.S. Department of Defense.

\section{U.S. Department of Energy, see DOE}

U.S. Environmental Protection Agency, see EPA 
THIS PAGE INTENTIONALLY LEFT BLANK 


\section{ANALYTICAL LABORATORY REPORT FOR LANDFILL A3-2 CLOSURE}




\section{CLIENT: Bechtel Nevada}

P.O. Box 98521, M/S NTS273

Las Vegas, NV 89193-8521

- ATTN: Ted Redding

\section{PROJECT NAME: NA}

PROJECT NUMBER: 17777

Attached are the analytical results for samples in support of the above referenced project. Samples submitted for this project were not sampled by NEL Laboratories. Samples were received by NEL in
good condition, under chain of custody on $8 / 6 / 98$.

Samples were analyzed as received.

Where applicable we have included the following quality control data:

Method blank - used to demonstrate absence of contamination or interferences in the analytical process.

Laboratory Control Spike (LCS) - used to demonstrate laboratory ability to perform the method within specifications by spiking representative analytes into a clean matrix.

Surrogates - compounds added to each sample to ensure that the method requirements are met for each individual sample.

Should you have any questions or comments, please feel free to contact our Client Services department at (702)
657-1010.

\section{Some results have been hagged as follows:}

Je - This concentration should be considered an estimate. The continuing calibration check standard did not meet $Q C$ requirements for this analyte.

I - The batch MS and/or MSD were outside acceptance limits. The batch LCS was acceptable.

Im - This concentration should be considered an estimate due to probable matrix effects.

Some surrogate results have been flagged as follows

D - Sample required dilution. Sample $Q C$ results were diluted outside the calibrated range.
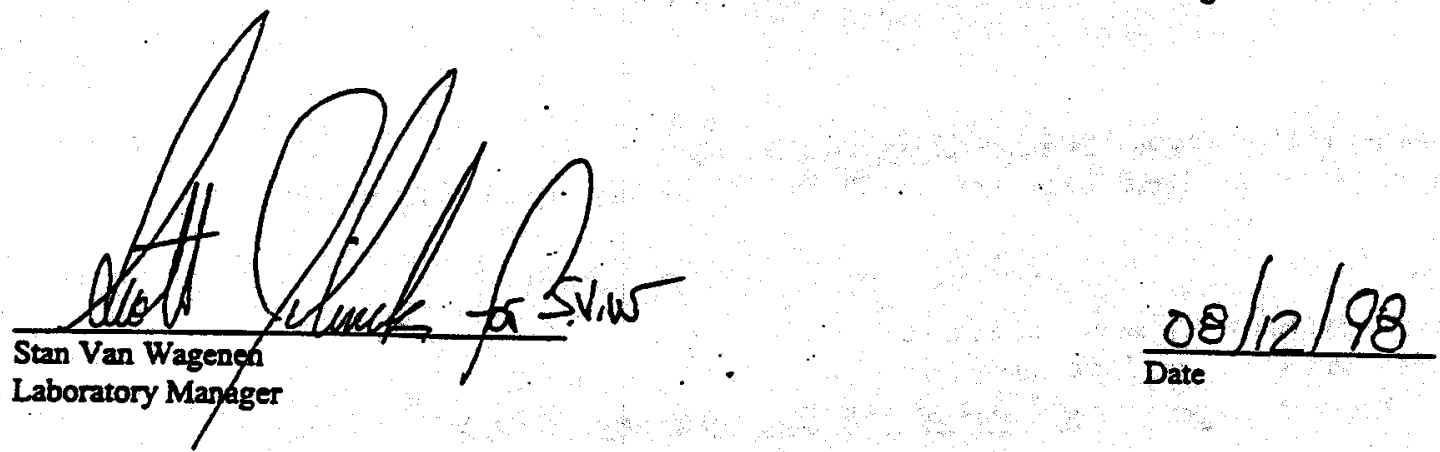

\section{CERTIFICATIONS:}

\begin{tabular}{|c|c|c|c|c|c|c|c|}
\hline & Reno & Las Vegas & S. Califomia & & Reno & Las Vegas & $\min$ \\
\hline $\begin{array}{l}\text { Arizona } \\
\text { California } \\
\text { US Army Corps } \\
\text { of Engineers }\end{array}$ & $\begin{array}{l}\text { AZ0520 } \\
1707 \\
\text { Certified }\end{array}$ & $\begin{array}{l}\text { AZ0518 } \\
2002 \\
\text { Certified }\end{array}$ & $\begin{array}{l}\text { AZ0583 } \\
2264 \\
\text { Certified }\end{array}$ & $\begin{array}{l}\text { Idaho } \\
\text { Montana } \\
\text { Nevada } \\
\text { Washington }\end{array}$ & $\begin{array}{l}\text { Certified } \\
\text { Certified } \\
\text { NV033 }\end{array}$ & $\begin{array}{l}\text { Certified } \\
\text { Certified } \\
\text { Nv052 }\end{array}$ & $\begin{array}{l}\text { CA084 } \\
\text { Certified }\end{array}$ \\
\hline
\end{tabular}


NEL LABORATORIES

CLIENT. BECHCA NeVada

PROJECT NAME: NA

PROJECT NUMBER: 17777

TEST: $\quad$ Total Extractable Petroleum Hydrocarbons by EPA Method 8015M, July 1992

METHOD: EPA 8015M

MATRD: Solid

ANALYST: Suzanne

\begin{tabular}{|c|c|c|c|c|c|c|c|c|c|}
\hline $\begin{array}{l}\text { CLDENT } \\
\text { SAMPLE ID }\end{array}$ & $\begin{array}{c}\text { SAMPLE } \\
\text { DATE }\end{array}$ & $\begin{array}{c}\text { NEL } \\
\text { SAMPLE D }\end{array}$ & $\begin{array}{c}\text { RESULT } \\
\text { mg/kg } \\
\end{array}$ & C.R. & $\begin{array}{c}\text { Reporting } \\
\text { Limit } \\
\end{array}$ & $\begin{array}{l}\text { Surroga } \\
\text { Recover } \\
\end{array}$ & & EXTRACTED & ANALYZED \\
\hline TIR A3-2 Sludge 3 & $8 / 5 / 98$ & L9808068-01 & 4800 & DO & 100. $\mathrm{mg} / \mathrm{kg}$ & 100 & $\%$ & $8 / 10 / 98$ & $8 / 11 / 98$ \\
\hline TIR A3-2 Sludge 4 & $8 / 5 / 98$ & L9808068-02 & $1500 \mathrm{Jm}$ & GDO & $10 . \mathrm{mg} / \mathrm{kg}$ & 33 & $\%$ & $8 / 10 / 98$ & $8 / 12 / 98$ \\
\hline TTR A3-2 Sludge5 & $8 / 5 / 98$ & L9808068-04 & $31000 \mathrm{Jc}$ & GDO & 500. $\mathrm{mg} / \mathrm{kg}$ & $D$ & $\%$ & $8 / 10 / 98$ & $\begin{array}{l}12 \\
819198 \\
x=01 / 8\end{array}$ \\
\hline TTR A3-2 Sludge6 & $8 / 5 / 98$ & L9808068-05 & 580 & DO & 10. $\mathrm{mg} / \mathrm{kg}$ & 70 & $\%$ & $8 / 10 / 98$ & $8 / 11 / 98$ \\
\hline TTR A3-2 Sludge7 & $8 / 5 / 98$ & L9808068-06 & $1600 \mathrm{Jm}$ & DO & 100. $\mathrm{mg} / \mathrm{kg}$ & 50 & $\%$ & $8 / 10 / 98$ & $8 / 11 / 98$ \\
\hline TIR A3-2 Sludge8 & $8 / 6 / 98$ & L9808068-07 & $420 \mathrm{n}$ & DO & 10. mg/kg & 81 & $\%$ & $8 / 10 / 98$ & $8 / 11 / 98$ \\
\hline TIR A3-2 Sludge9 & $8 / 6 / 98$ & L9808068-08 & ND & & 10. $\mathrm{mg} / \mathrm{kg}$ & 89 & $\%$ & $8 / 10 / 98$ & $8 / 11 / 98$ \\
\hline TTR A3-2 Sludge10 & $8 / 6 / 98$ & L9808068-09 & $1400 \mathrm{Jm}$ & GDO & 10. $\mathrm{mg} / \mathrm{kg}$ & 36 & $\%$ & $8 / 10 / 98$ & $8 / 12 / 98$ \\
\hline TIR A3-2 & $8 / 6 / 98$ & L9808068-10 & ND & & $10 . \mathrm{mg} / \mathrm{kg}$ & 91 & $\%$ & $8 / 10 / 98$ & $8 / 11 / 98$ \\
\hline
\end{tabular}

\section{CR: Carbon Range}

DO Diesel Range Organics (C12 to C34) and Oil Range Organics (C12 to C38).

GDO Gas Range Organics ( $\mathrm{C} 8$ to $\mathrm{C12}$ ), Diesel Range Organics ( $\mathrm{C} 12$ to $\mathrm{C24}$ ) and Oil Range Organics (C12 to C38).

Note: The reporting limit for Oil Range Organies in soil is $50 \mathrm{mg} / \mathrm{kg}$.

QUALITY CONTROL DATA (Total for Gas and Diesel Range): .

Sample ID

Blank, 980810 phs -BLK

LCS, 980810 tphs - LCS

MS, 980810 tphs - MS

MSD, 980810 tphs - MSD
Result Acceptable Range Surrogate Recovery* Sample Number

$\begin{array}{lllllll}\text { ND } & & < & 10 . \mathrm{mg} / \mathrm{kg} & 105 \% & \text { NA } \\ 86 & \% & 55 & -102 \% & 107 \% & \text { NA } \\ 79 & \% & 38 & -107 \% & 51 \% & \text { L9808068-07 } \\ 104 \% & 38 & -107 \% & 69 \% & \text { L9808068-07 }\end{array}$

ND - Not Detected

"Surrogate used was Octacosane, acceptance limits $54-130 \%$ for solids, $60-121 \%$ for aqueous samples

This report shall not be reproduced except in full, without the written approval of the laboratory. 
PROJECTI CLIENTIMFORMATION REPORI IMFORMATIOM

Projoctire drea 3 Landfill Conaler BN Oogl: 2150 Charge No.

$$
\text { CUP-IBODE }
$$

AsL Prog:

Send Report to: Dave Madsen Phone: $295^{\circ}-7211 \mid \frac{295-7761}{\text { Fax: }}$ Turneround (1) Slandard - 30 days Non-rad 30 NTS 306 Profect Manager: S. Na.het /D. Madsen
Phone:

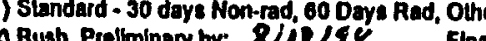

Final report format: (X) Standard (INTS-WAC () Other: SAMPLEIMFORMATIOH

\section{Sampling sile: TrR A3-2 Laadfull}

The samples submitied contan (check):

(1) Haxirdous (1) Radloscllve (S Unknown

conlamlnation. If known, attach a brial narrative eummany compllance with appilicable regulations and allow for the sate handiling of the eample matertals.

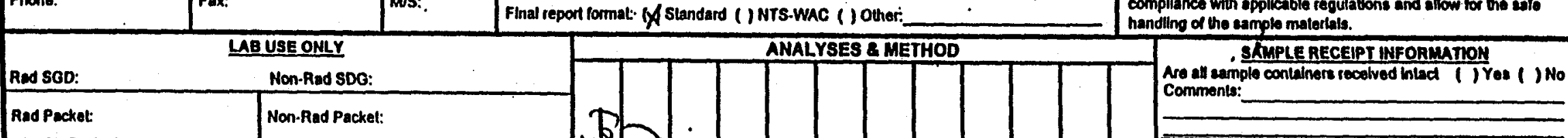

CMeni Senvices Representative:

Whit these analyses be performed under a sloned SOWn () YES ( INO if so, do enalyeses onlered here agree with the sown () YES () NO () N/A II not bently the vartation

CSR hiltelas indicating review and approval: Dete:

(0)

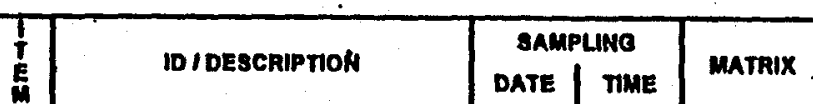

T TTR 43-2 Sludge 3 8/5/201510 Soil

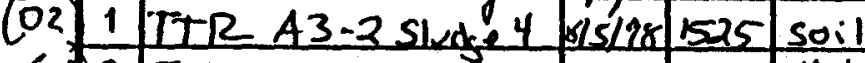

(c) 2 EB O80598

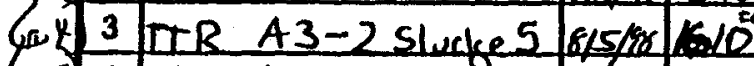

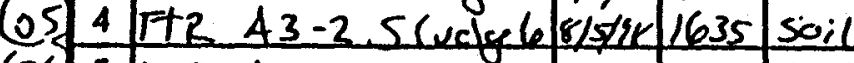

6065 TIR A3-2 Sludge 7 5/5/16. 1645 So,

67) 6 TIR. A 3-2 Sludke 8 $4(4)$ s. 1145

C8) 7 TIRA 3-2 siudse 9 8/6/4. 1155

C7 8 TTR 4 3 -2 Sludce 10 ol6/ex 1325

Soi

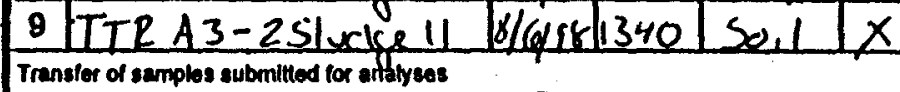

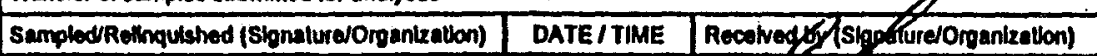

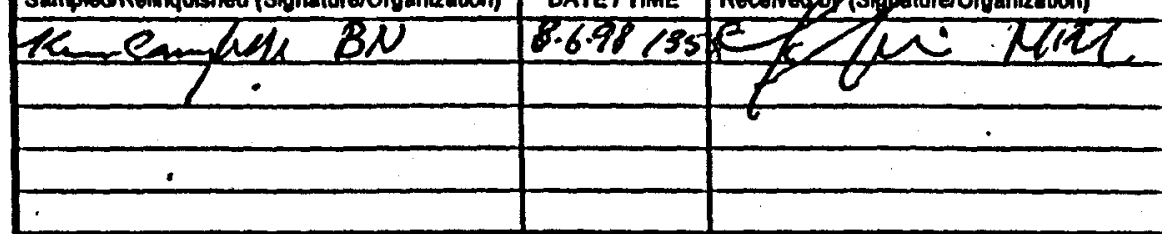

\begin{tabular}{|c|c|c|}
\hline \multicolumn{3}{|c|}{ Complete for samples shipped lo an Off.site Subcontract Laboratory } \\
\hline Relinquilshed (BN Represenlativo Slanaturi) & DATE ITME & Recolved (C" Ser \& Trecting Info.) \\
\hline Rolinqulshed (Courler \& Tracking In(o.) & DATE / TIME & Recotved (1at Her Subcontractor Rep) \\
\hline Rellinqulatiod (Iol tor Subcontractor Rep) & DATE/TIME & Recetred (2nd ter Subcontrector Rop) \\
\hline
\end{tabular}

Do the labels agree with this form? ( ) Yee ( INo

$$
\text { Comments: }
$$
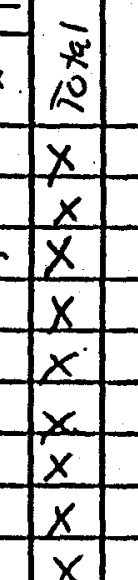
Degntel nevada

ANALYTICAL SERVICES LABORATORY

DATA PACKAGE RENEW CHE_.LUIST

SAMPLE DELIVERY GROUP: $V 486$ LABORATORY: NFL

CLIENT: ER - DAVE MADSEN

FINAL REPORT RECEIVED: $10 / 20 / 98$

DATE REVIEWED: 10/21/98

PH - GASOLINE I DIESEL / OIL:

MATRIX: SOIL \& WATER

1. QC SAMPLES ACCEPTABLE

2. MATRIX SPIKE ACCEPTABLE

3. METHOD BLANK ACCEPTABLE

4. HOLDING TIMES ACCEPTABLE

a. Earliest Date Sampled:

b. Date ASL Received:

c. Date Contract Lab Received:

d. Latest Date Extracted:

e. Latest Date Analyzed:

\begin{tabular}{c} 
YES \\
\hline YES \\
\hline YES \\
\hline YES \\
\hline
\end{tabular}

\#DAYS

0

NRA

8/6/98

$8 / 11 / 98$

$8 / 12 / 98$

5. CALCULATIONS ACCEPTABLE:

6. CORRECT CONC. UNITS USED:

7. FORMS ACCEPTABLE:

8. CHAIN-OF-CUSTODY AGREES:

NRA

1

6

1

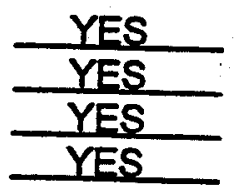

ARE TPHDATA ACCEPTABLE: YES

ARE CRITERIA MET

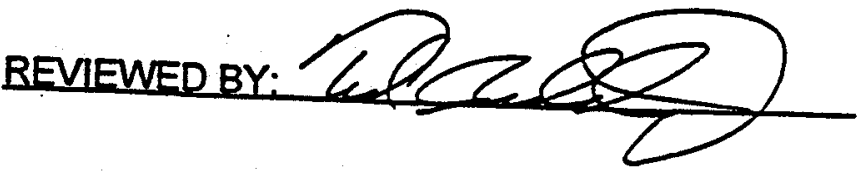

ACCEPTABLE

0

$\frac{\frac{1}{5}}{\frac{14}{40}}$

COMMENTS: Method associated quality assurance and control criteria were met. The reported "Analyzed" date for TIR A3-2 Sludge 5 did not agree with the raw data. The date was corrected according to the raw data and initialed. Preliminary data were faxed to the client on August 13.1998.

TPHD/O-1 
NEL LABORATORIES

CLIENT. Bechict NEVtoha

PROJECT NAME: NA

PROJECT NUMBER: 17777

TEST: $\quad$ Total Extractable Petroleum Hydrocarbons by EPA Method 8015M, July 1992

METHOD: EPA 8015M

MATRIX: Aqueous

ANALYST: Suzanne

\begin{tabular}{|c|c|c|c|c|c|c|c|c|}
\hline $\begin{array}{l}\text { CLIENT } \\
\text { SAMPLE W } \\
\end{array}$ & $\begin{array}{c}\text { SAMPLE } \\
\text { DATE }\end{array}$ & $\begin{array}{c}\text { NEL } \\
\text { SAMPLE I }\end{array}$ & $\begin{array}{c}\text { RESULT } \\
\text { mg/L } \\
\end{array}$ & C.R. & $\begin{array}{c}\text { Reporting } \\
\text { Limit } \\
\end{array}$ & $\begin{array}{l}\text { Surrogate } \\
\text { Recovery* }\end{array}$ & EXTRACTEL & D \\
\hline В 080598 & $8 / 5 / 98$ & L9808068-03 & ND & & $0.5 \mathrm{mg} / \mathrm{L}$ & $88 \%$ & $8 / 11 / 98$ & $8 / 12 / 98$ \\
\hline
\end{tabular}

\section{CR: Carbon Range}

DO Diesel Range Organics (C12 to C34) and Oil Range Organics (C12 to C38).

GDO Gas Range Organics (C8 to C12), Diesel Range Organics (C12 to C24) and Oil Range Organies (C12 to C38).

Note: The reporting limit for Oil Range Organics in soil is $50 \mathrm{mg} / \mathrm{kg}$.

QUALITY CONTROL DATA (Total for Gas and Diesel Renge): .

\section{Sample Im}

Blank, 980811 tph -BLK

LCS, 980811 tph - LCS

LCSD 980811 tph - LCSD
Resuit Acceptable Range Surrogate Recovery Sample Number

$\begin{array}{lllllll}\text { ND } & & < & 0.5 \mathrm{mg} / \mathrm{L} & 79 \% & \text { NA } \\ 78 & \% & 61 & -104 \% & 107 \% & \text { NA } \\ 82 & \% & 61 & -104 \% & 116 \% & \text { NA }\end{array}$

ND - Not Detected

-Surrogate used was Octacosane, acceptance limits $54-130 \%$ for solids, $60-121 \%$ for aqueous samples

This report shall not be reproduced except in full, without the written approval of the laboratory. 


\section{APPENDIX B}

\section{AS-BUILT ENGINEERING DRAWINGS}




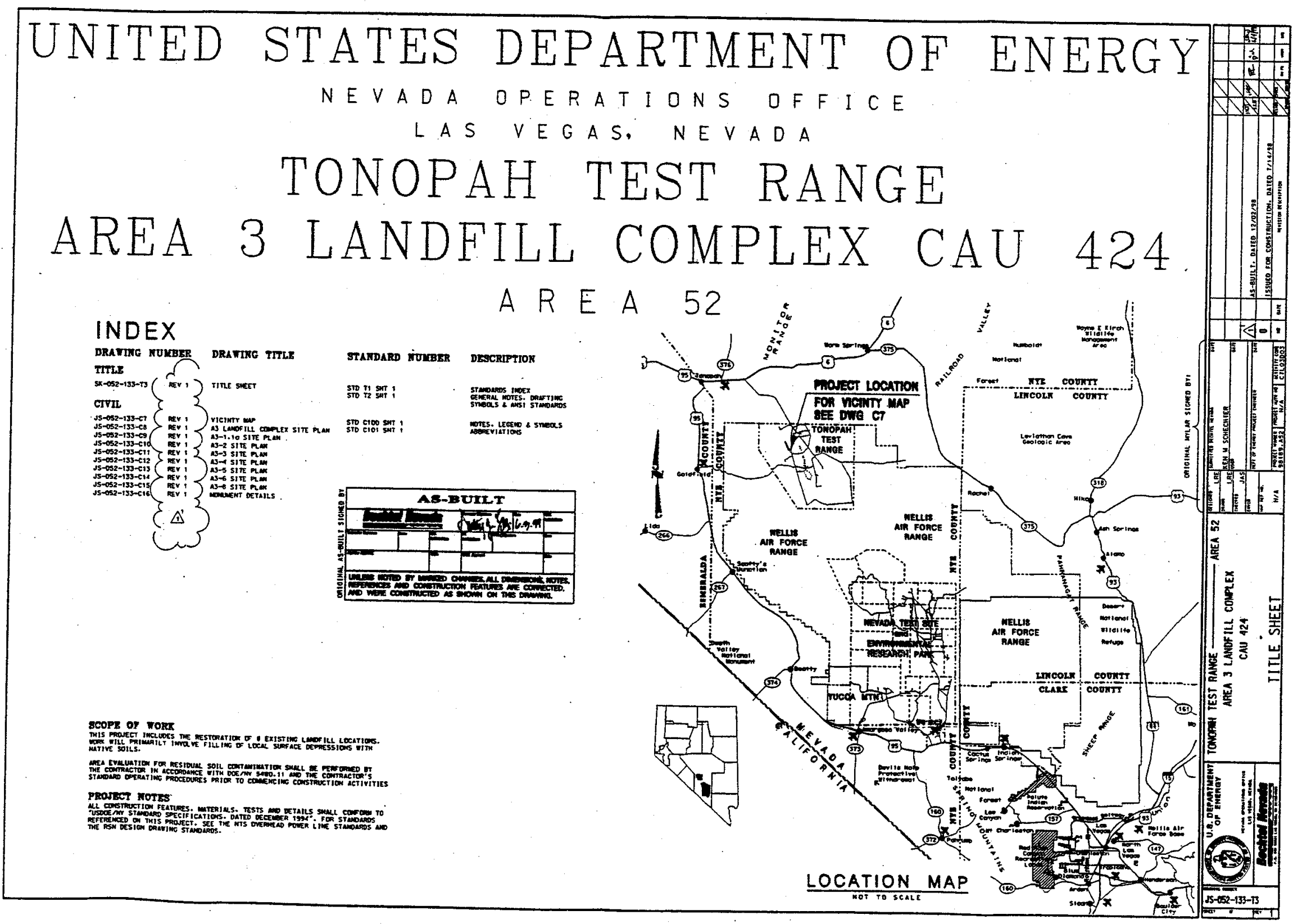




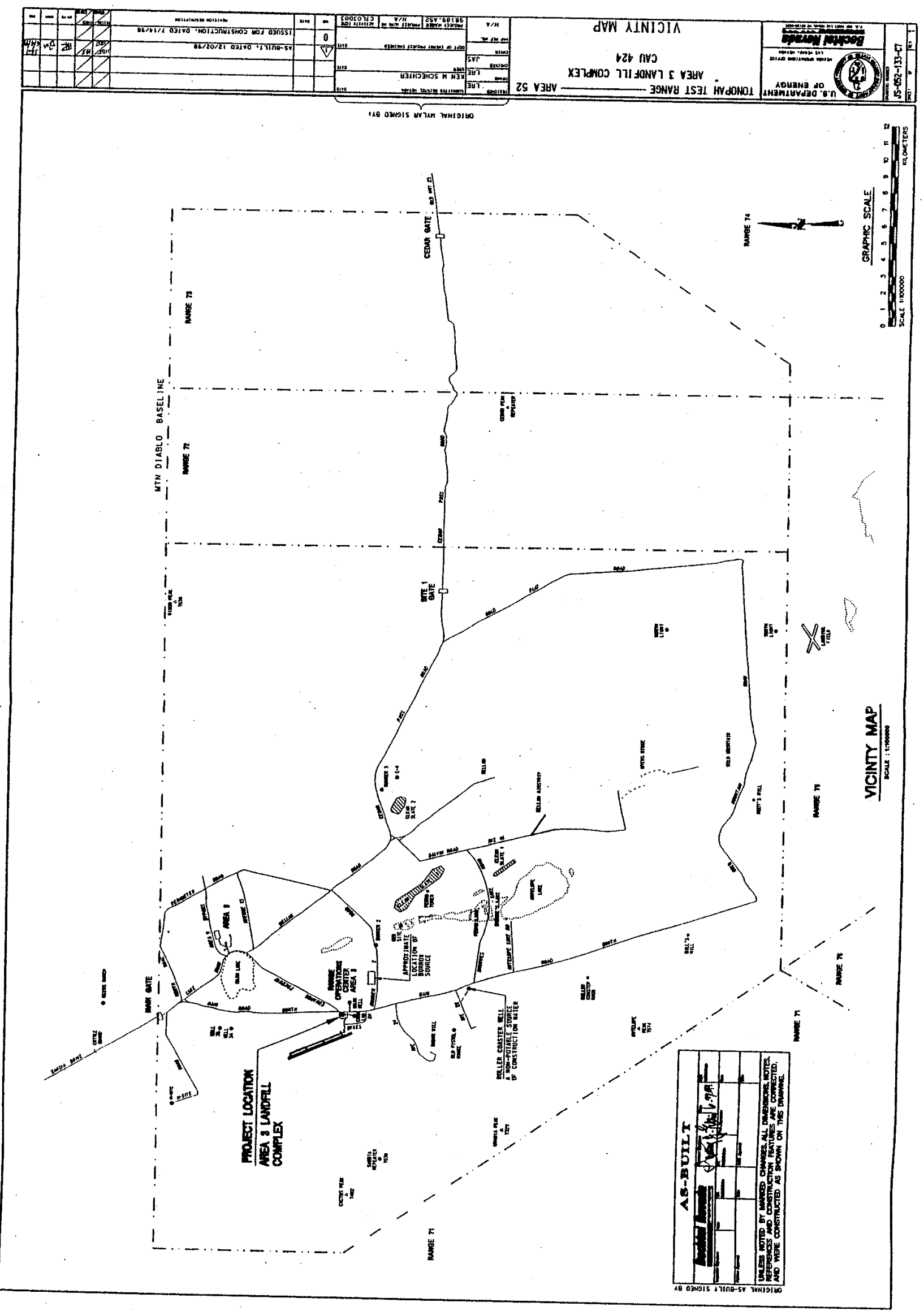




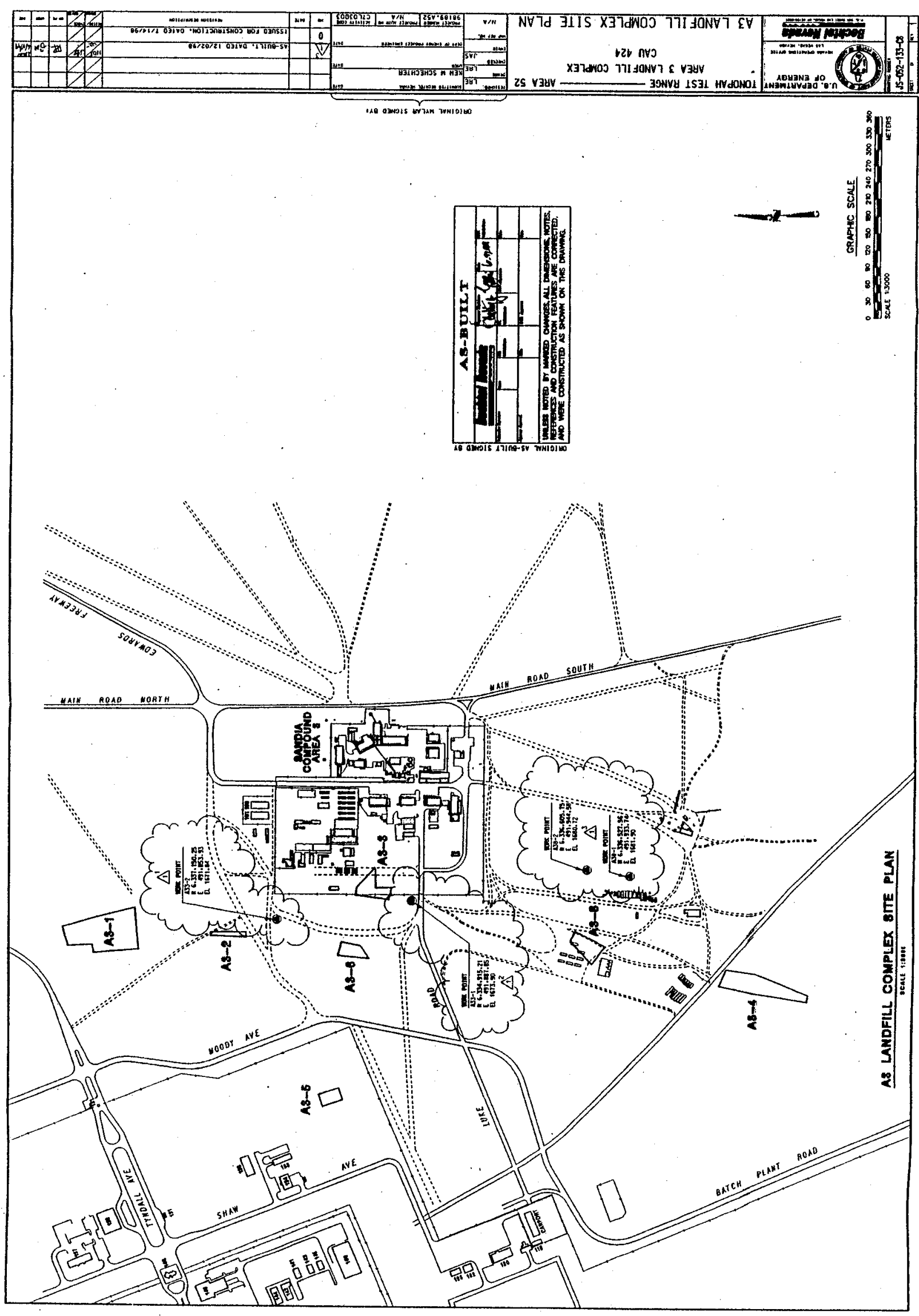




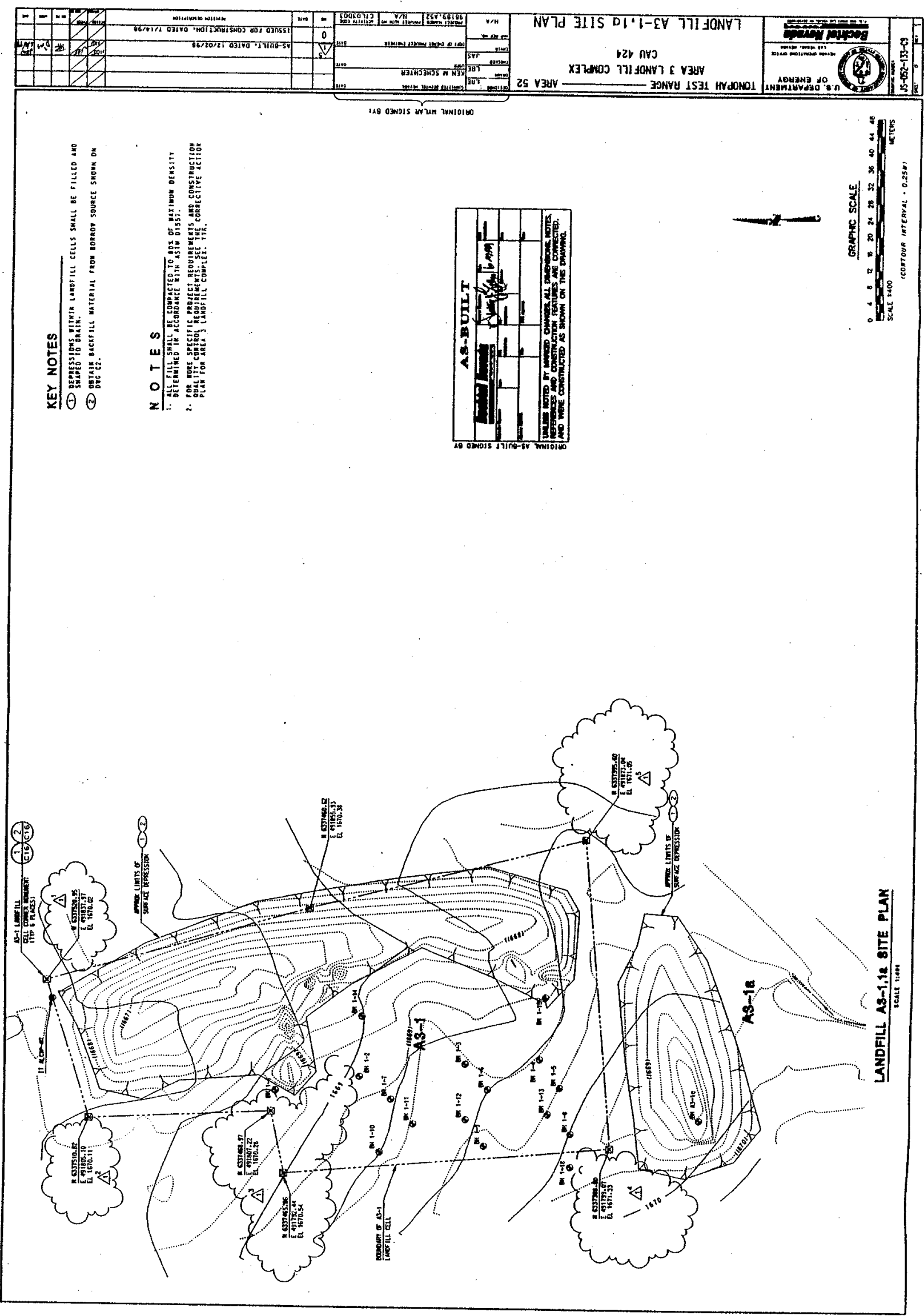




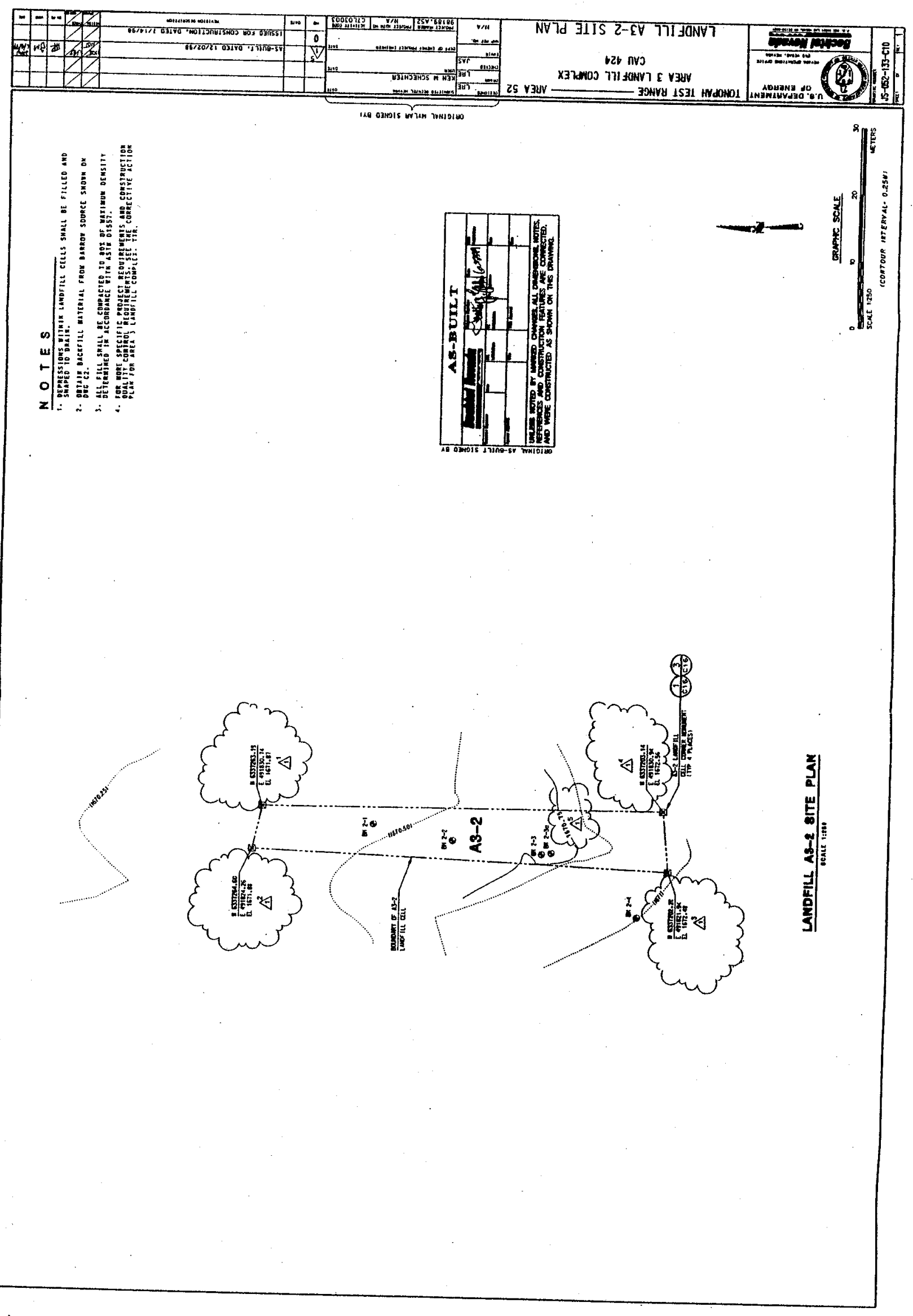




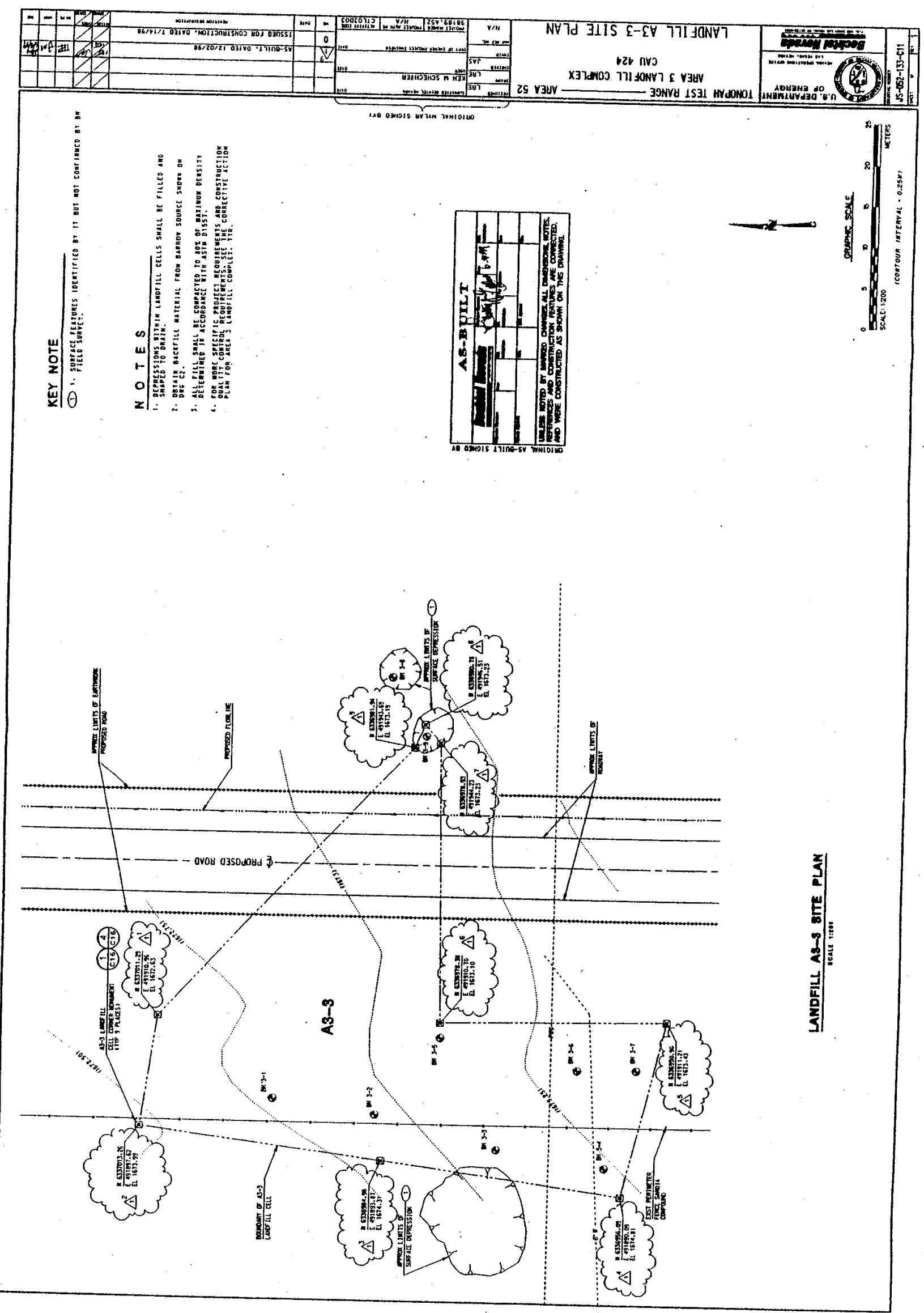




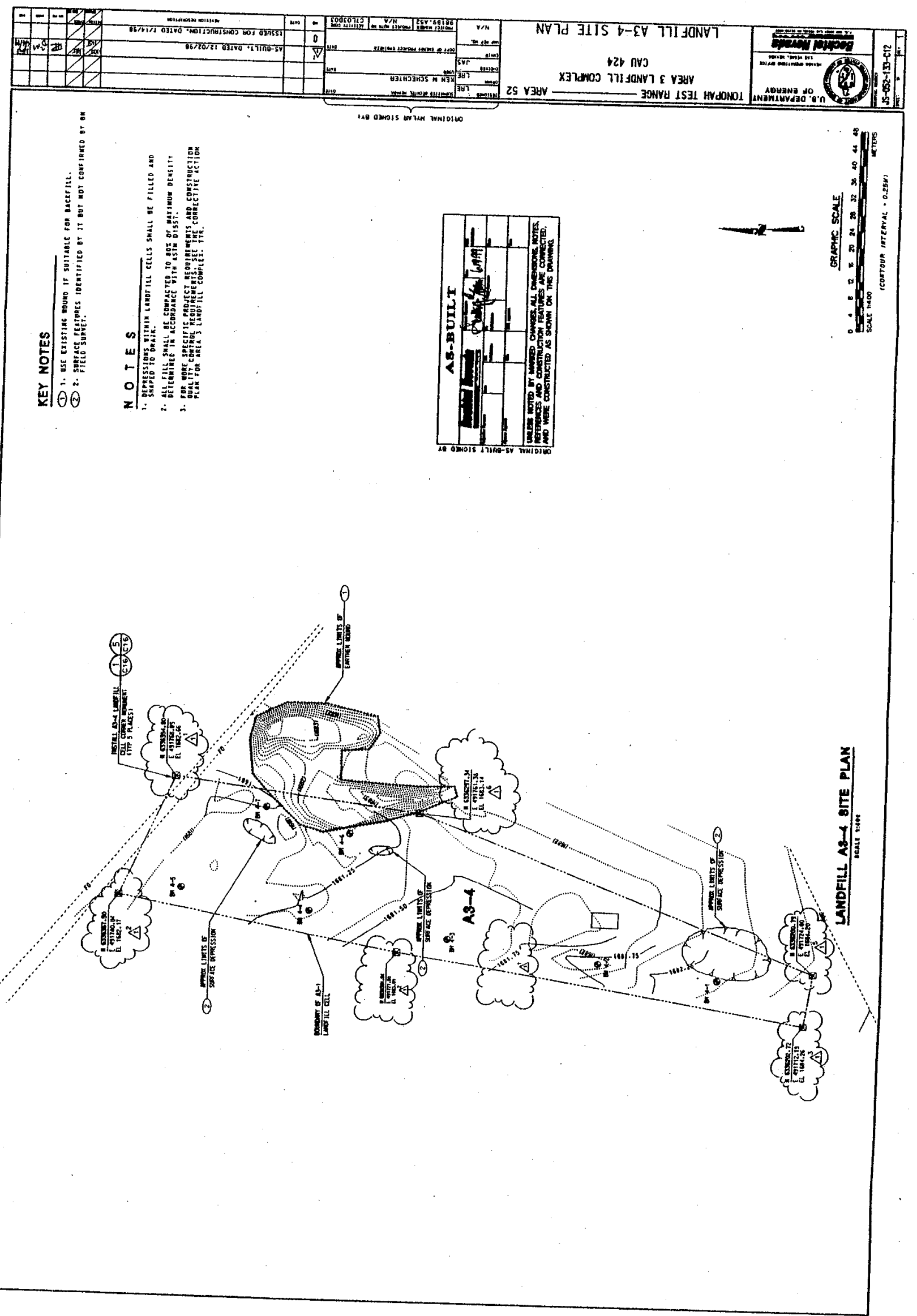




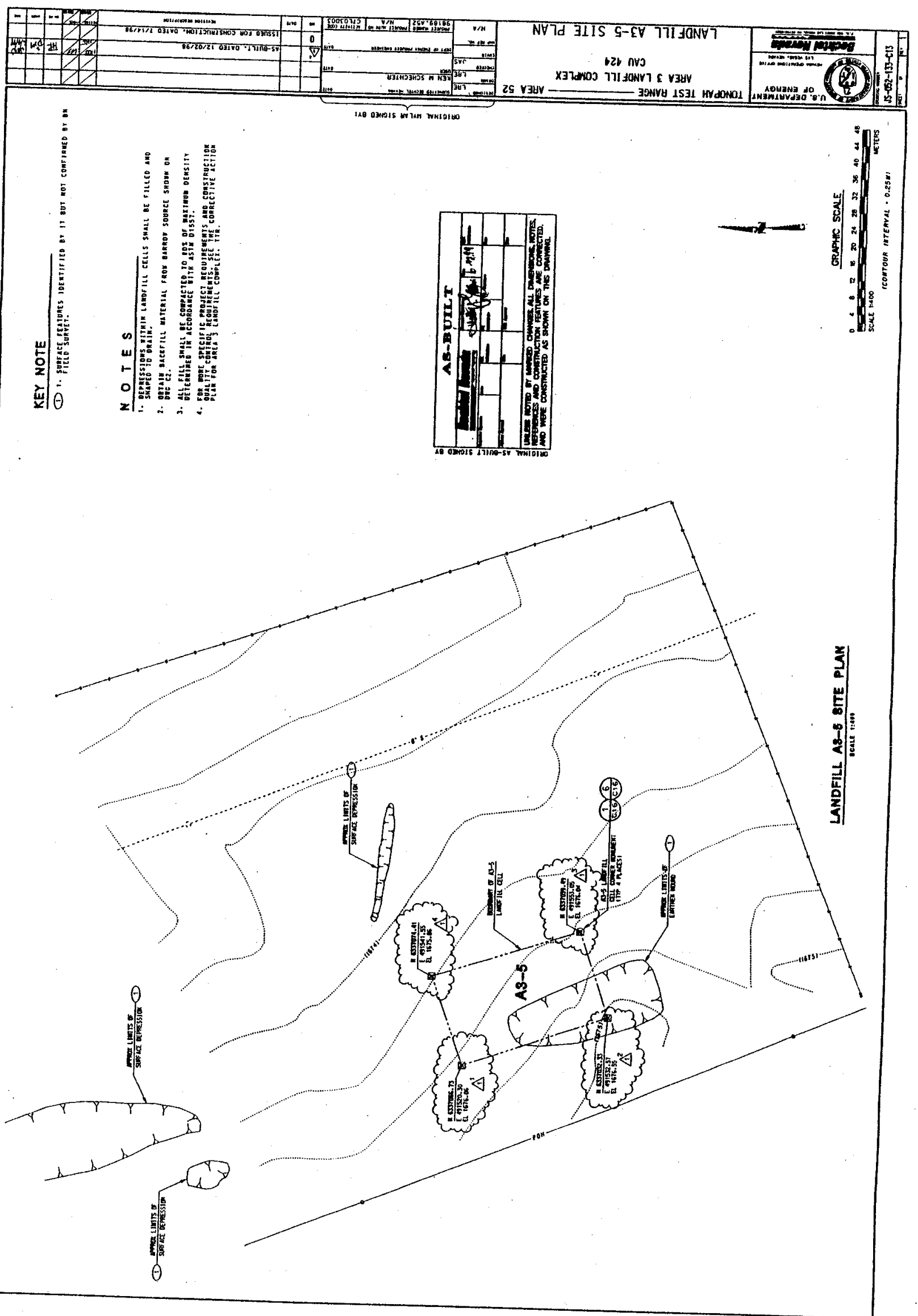




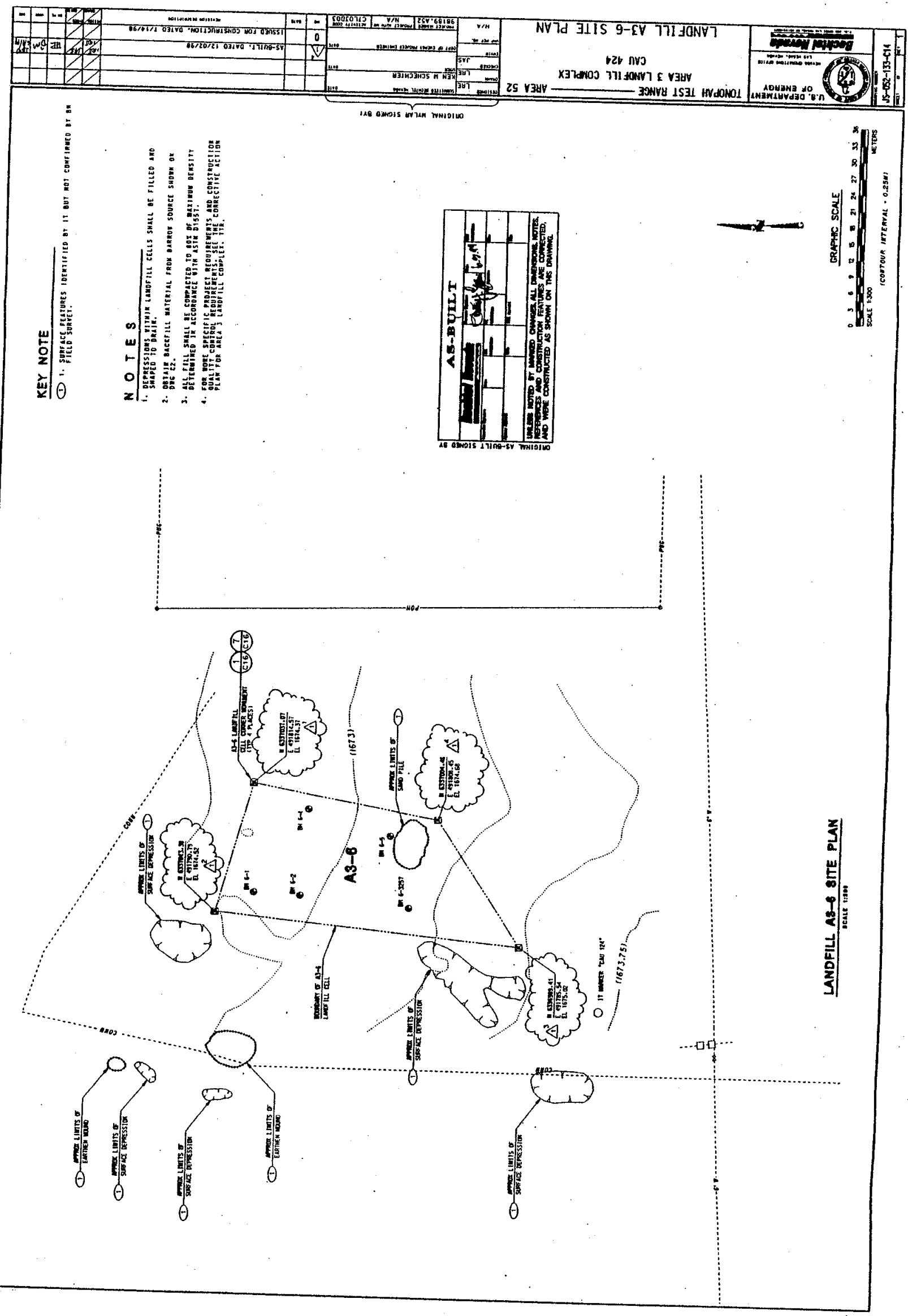




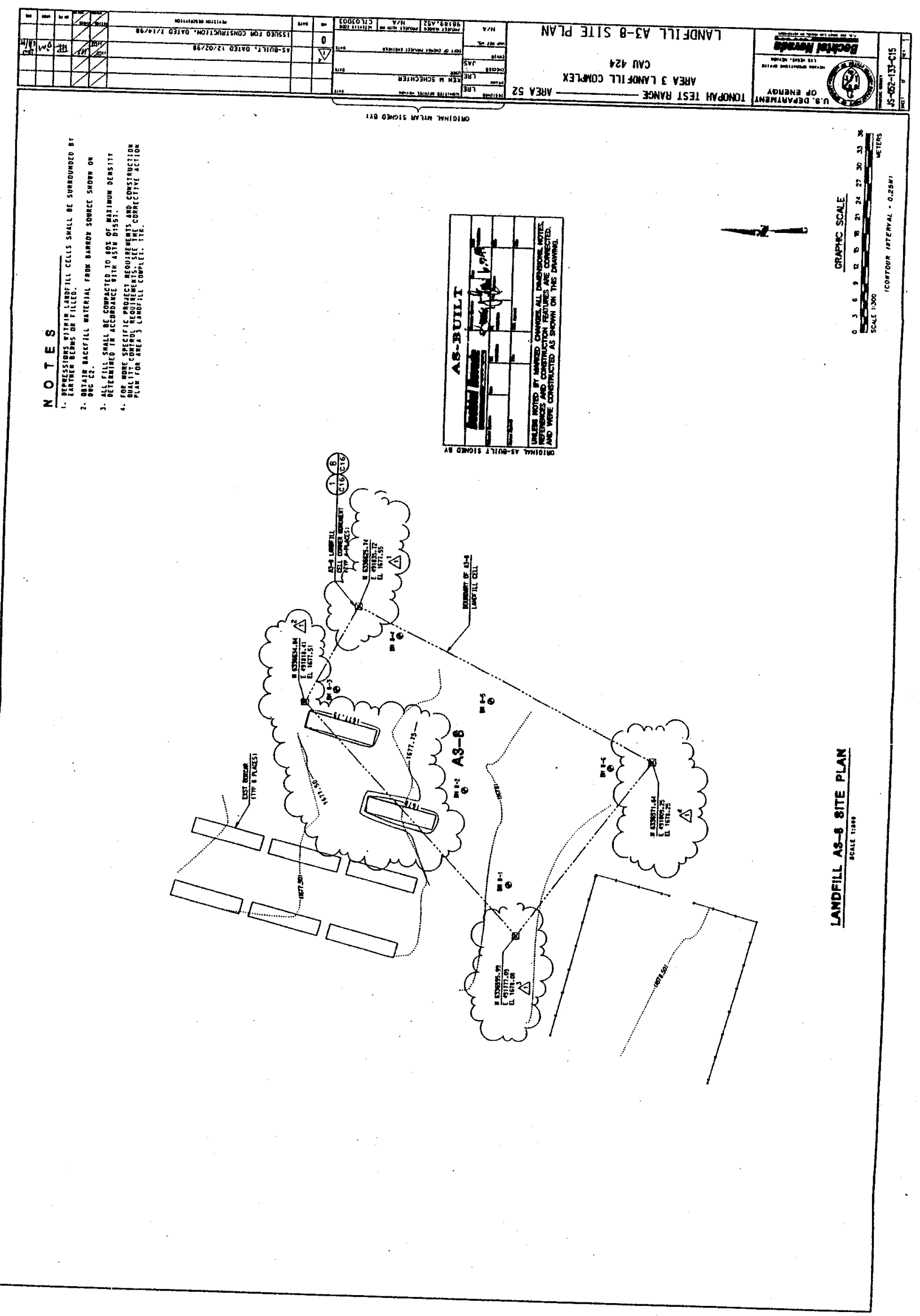




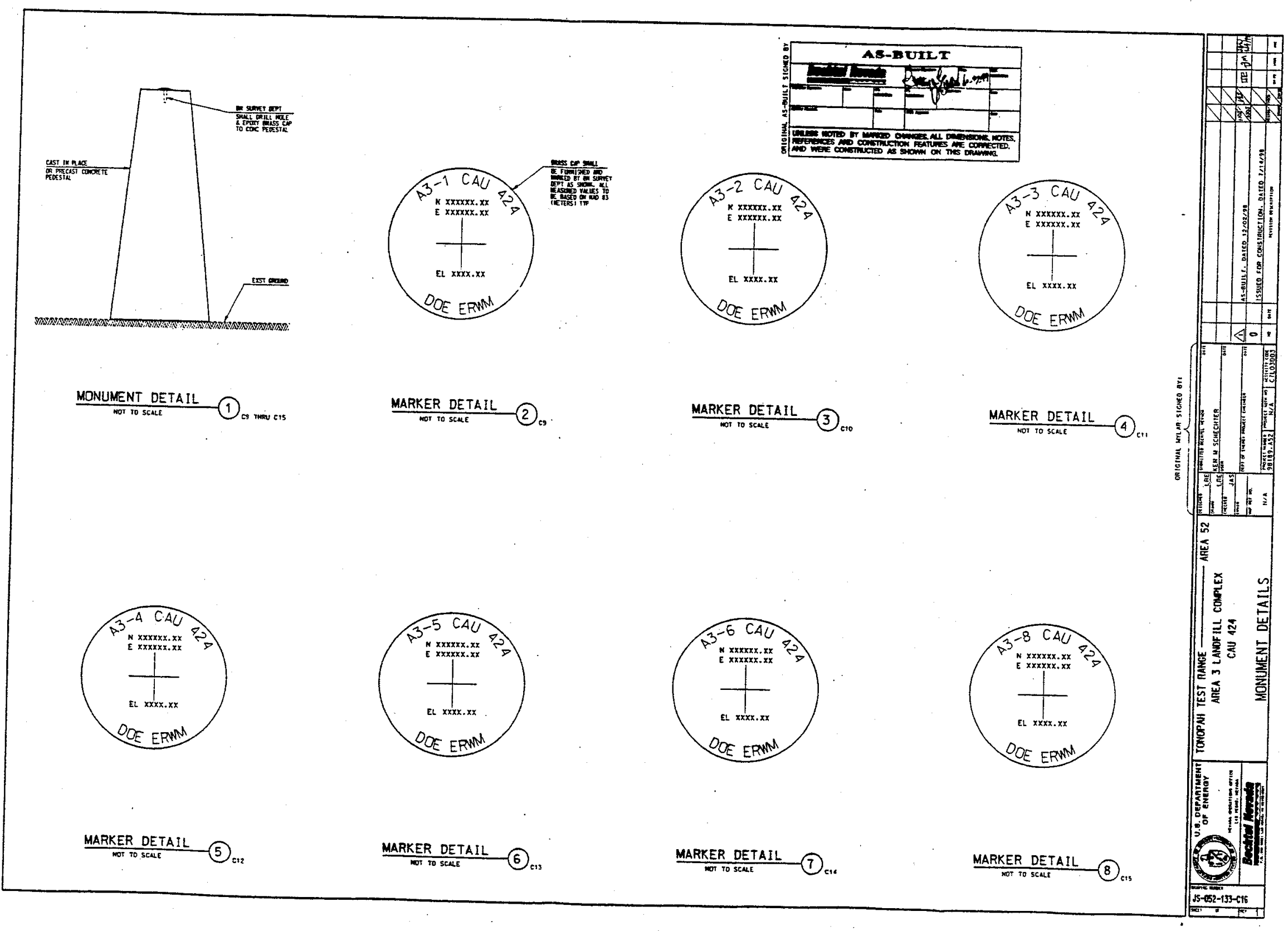


Revision: 0

Date: July 7, 1999

\section{APPENDIX C}

\section{WASTE DISPOSAL DOCUMENTATION}




\section{Bechtel Nevada}

Interoffice Memorandum

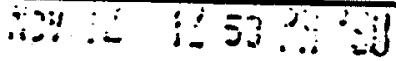

To:

D. D. Madsen

Date: November 9, 1998

From: C. A. Stowell, Project Manager

Solid Waste Management, 295-6904

No.: 2150-CS-99-0010
Subject: DISPOSAL RECOMMENDATION FOR WASTE GENERATED FROM CORRECTIVE ACTION UNIT (CAU) 424 - AREA 3 LANDFILL COMPLEX, TONAPAH TEST RANGE (TTR)
Project No. 04047

Waste Management Program/Solid Waste Management personnel, concur with the characterization you have made for the waste generated during closure excavation activities at the CAU 424 Area 3 Landfill Complex at TTR.

The contents of the 11 containers, assigned waste tracking number BN- 0453 and Wixel@ tracking numbers BN-NTS-99-0001 through -0011, are not regulated under the Resource Conservation and Recovery Act, and can be sent to either the Area 6 Hydrocarbon or U10c Landfill. All free liquids must be absorbed prior to disposal. To arrange disposal, please submit a "Waste Management Program/NoniRad Request for Services" form BN-0766, with a charge number to C. C. Gonzales at M/S NTS207.

If you have questions, please call S. S. Simplicio at 295-4838.

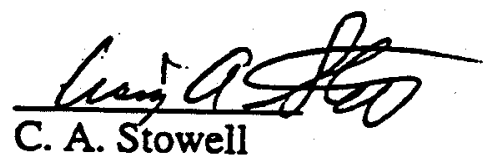

SSS/CAS:cjs

Subject Code: WMT3

cc: Correspondence Control, NLV008

J. K. Brooks, NLV080

J. A. Dickinson, NLV080 =-

EM Correspondence, NLV080

J. M. Elkins, NTS110

J. M. Fowler, NTS110

C. C. Gonzales, NTS207

R. H. Guymon, NTS327
A. M. Heidema, NLV102
S. J. Nacht, NTS306
C. J. Schwartze, NTS207
S. S. Simplicio, NTS207
C. A. Stowell, NTS207
L. S. Sygitowicz, NLV080
D. A. Watson, NLV022 


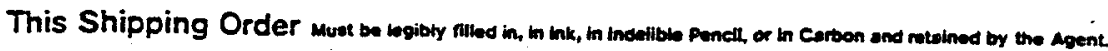

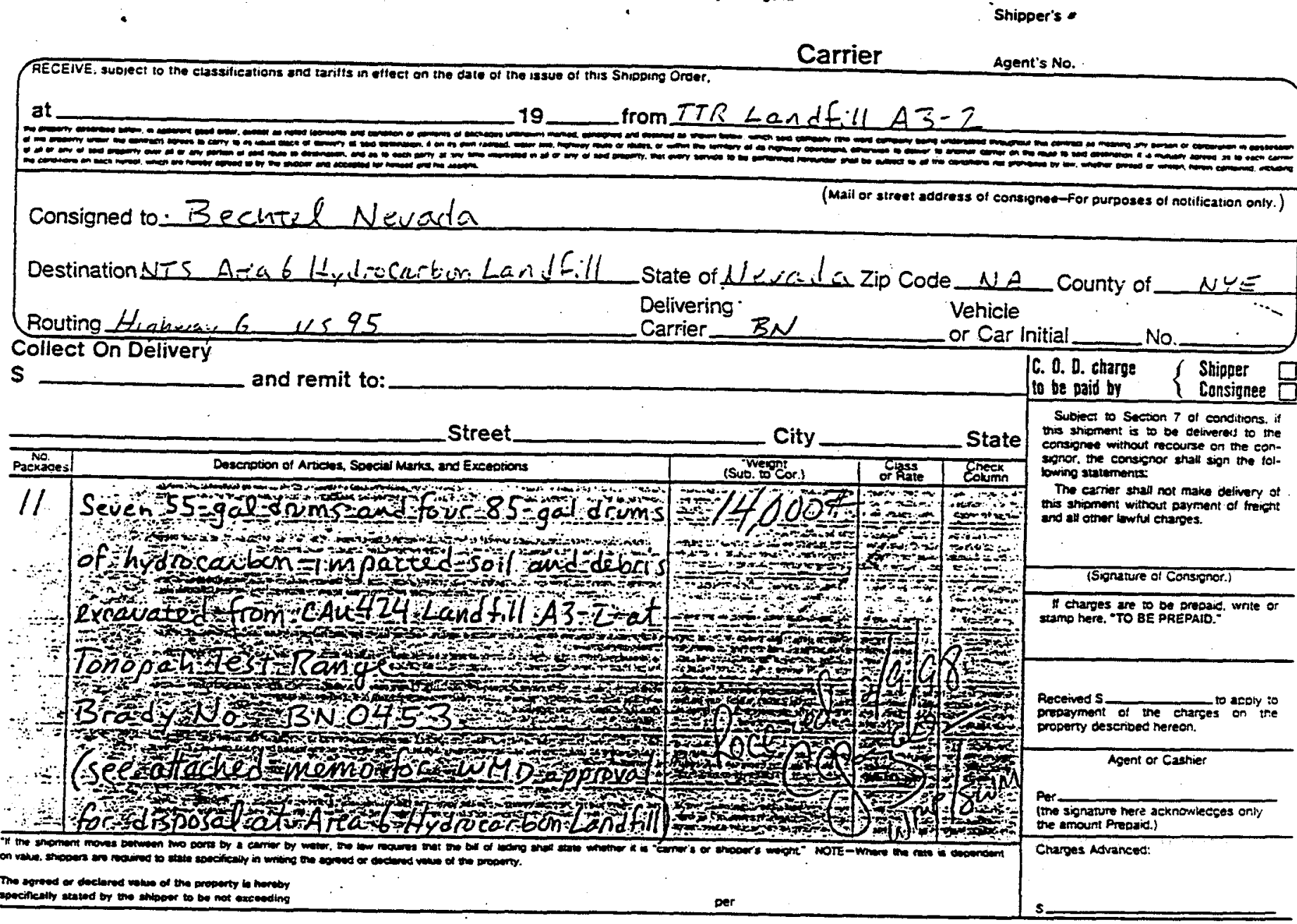





\section{Bechtel Nevada}

RADIATION SURVEY REPORT

Page 1 ol 1

ACT(s): Colglazier

INSTAUMENT(S) TYPE \& NO:

\begin{tabular}{|c|}
\hline COUNTING \\
INFORMATION \\
\hline DATE SUTVEYE: \\
$8=27-98$ \\
\hline
\end{tabular}

Flect

SIGMATUAE

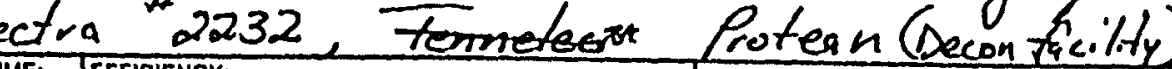
CONT IME:

$1 \mathrm{~min} \quad \alpha 31.23 \quad \beta .43 .77$ CORAECTION FACTOA:

EVEN COOE: PUAPOSE: Green Tag Survey

ALL AEADINGS MEET UNAESTRICTED RELEASE LIMITS? EYES . $\mathrm{C}$ NO (SEE COMMENTS)

\begin{tabular}{|c|c|c|c|}
\hline $\begin{array}{c}\text { SAMPLE } \\
\text { NO. }\end{array}$ & TIME & $\begin{array}{c}\text { OATE } \\
\text { ANALYZED } \\
\end{array}$ & DESCAIPTION OF SUAVEY \\
\hline$N / 4$ & $N / A$ & $8-28-98$ & BACKGHOUND \\
\hline 1 & 2000116 & $B-28-98$ & Soil, Debris Bile (A-3 TTR) \\
\hline 2 & 0934 & $8 \div 28-98$ & Drums $(A-3$ TTR \\
\hline & & & \\
\hline & & & \\
\hline & & & \\
\hline & & & \\
\hline & & & $N$ \\
\hline & & & \\
\hline & $\cdot$ & & \\
\hline & & & \\
\hline & & & \\
\hline & & & \\
\hline & & & \\
\hline & • & & \\
\hline
\end{tabular}

COMMENTS:
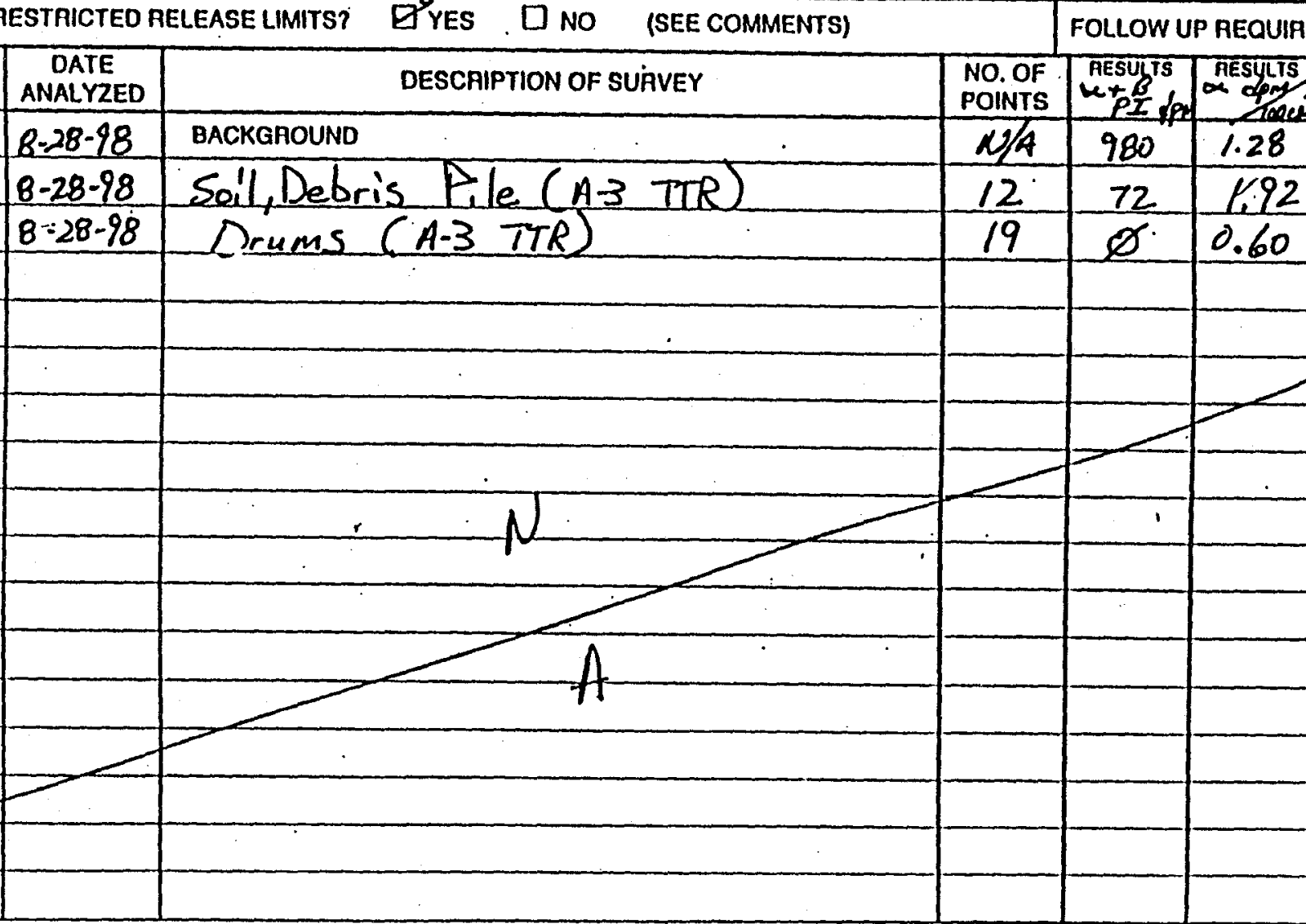

Bartrand

HEALTH.PHYSICIST: $P$ (Ind

MDA

$\alpha 15: 66 \quad \beta / 3.24$ AEOUESTERAWP NO:

FOLLOW UP REQUIRED? $\square$ YES RTNO

Q RESULIS

receit $100 \mathrm{~cm}{ }^{2}$

\begin{tabular}{|l|l|l|}
1.283 \\
\hline 4.92 & 9.60 \\
\hline
\end{tabular}

12

.92

9.60

5.03 
DATE: $9.14 \cdot 9^{C}$ NO. A000.147

\section{Bechtel Nevada}

Radiological Control Department- Ramatrol

\section{Material Clearance}

MONTOR: R.lule-iin

ISSUING ORganization: PNER

REQUESTING ORGANIZATON: BNER

SUAVEY LOCATION: TTR A-3

FROM:

4.2

TO:

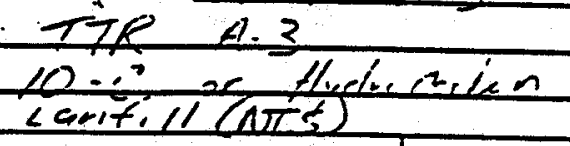
THIS MATERIAL HAS BEEN SUURVYED
FOR RADIOACTIVTY AND MEETS

DOE STANDARDS FOR RELEASE TO PUBUC USE

INITIAL

\begin{tabular}{l|l}
. TO PUBuC use & fy \\
\hline
\end{tabular}
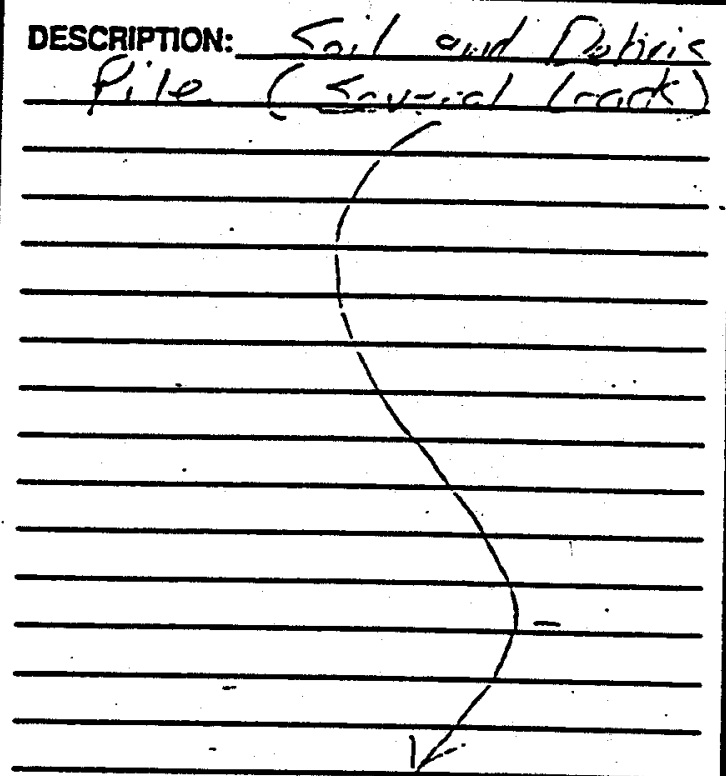

REMARKS:

$E, 2 \ldots$

$9-21-92$

THIS TAG EXPIRES 7 DAYS FROM

ISSUE DATE

COPY 1: PO RECOROS WS NTSUSO

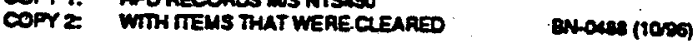




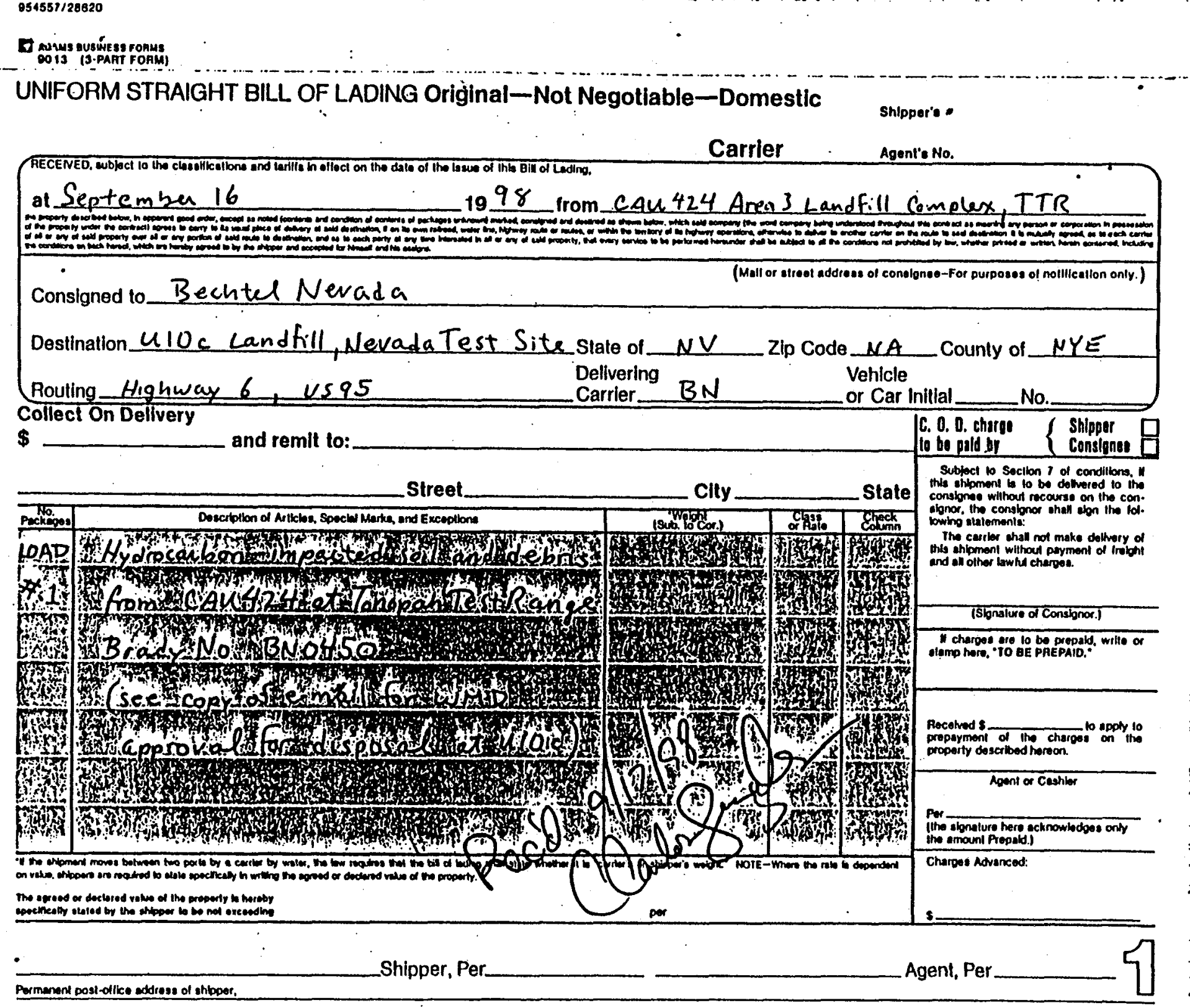

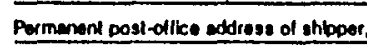

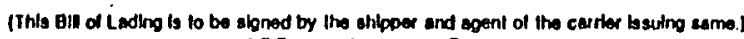

Bill of Lading 


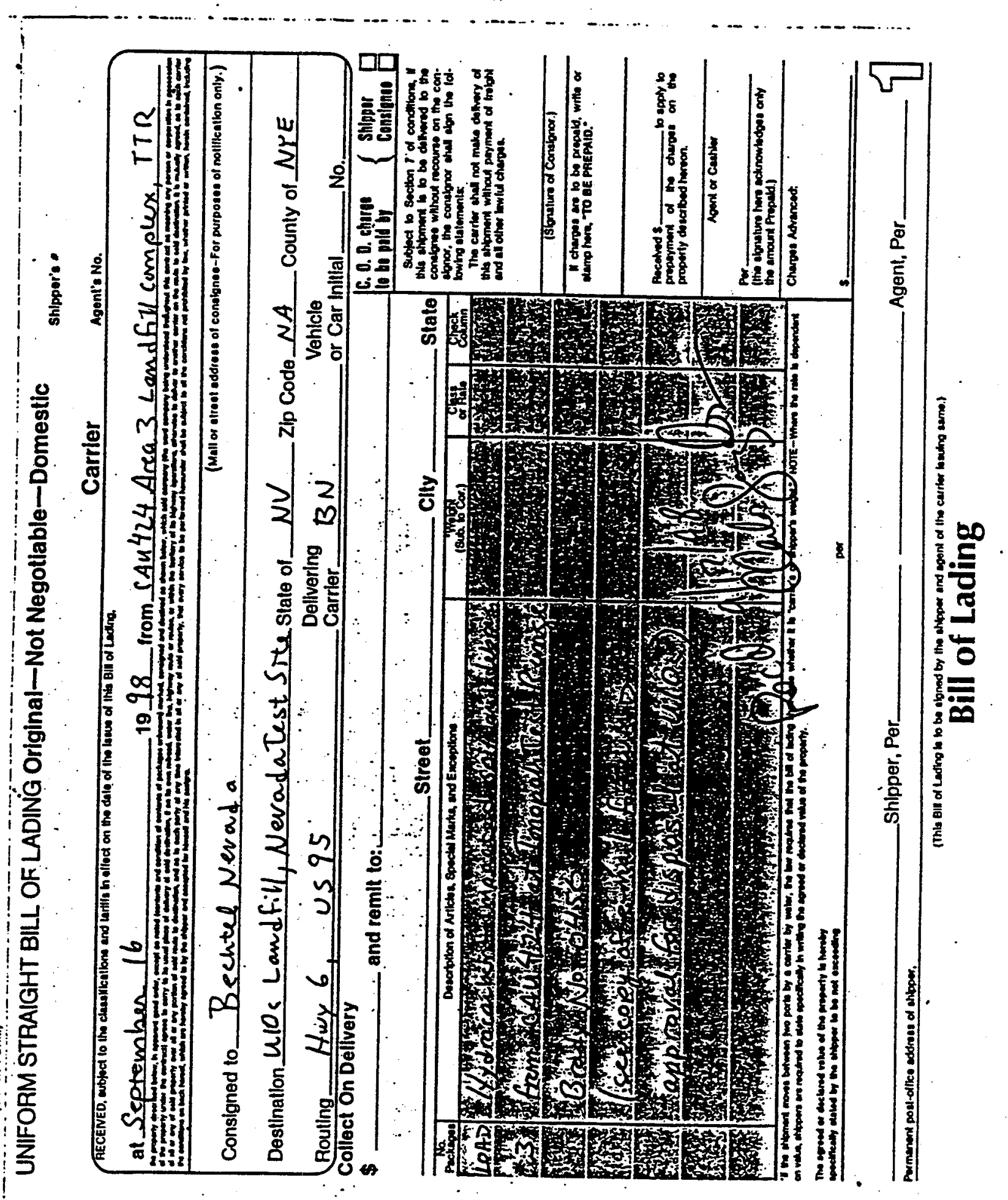




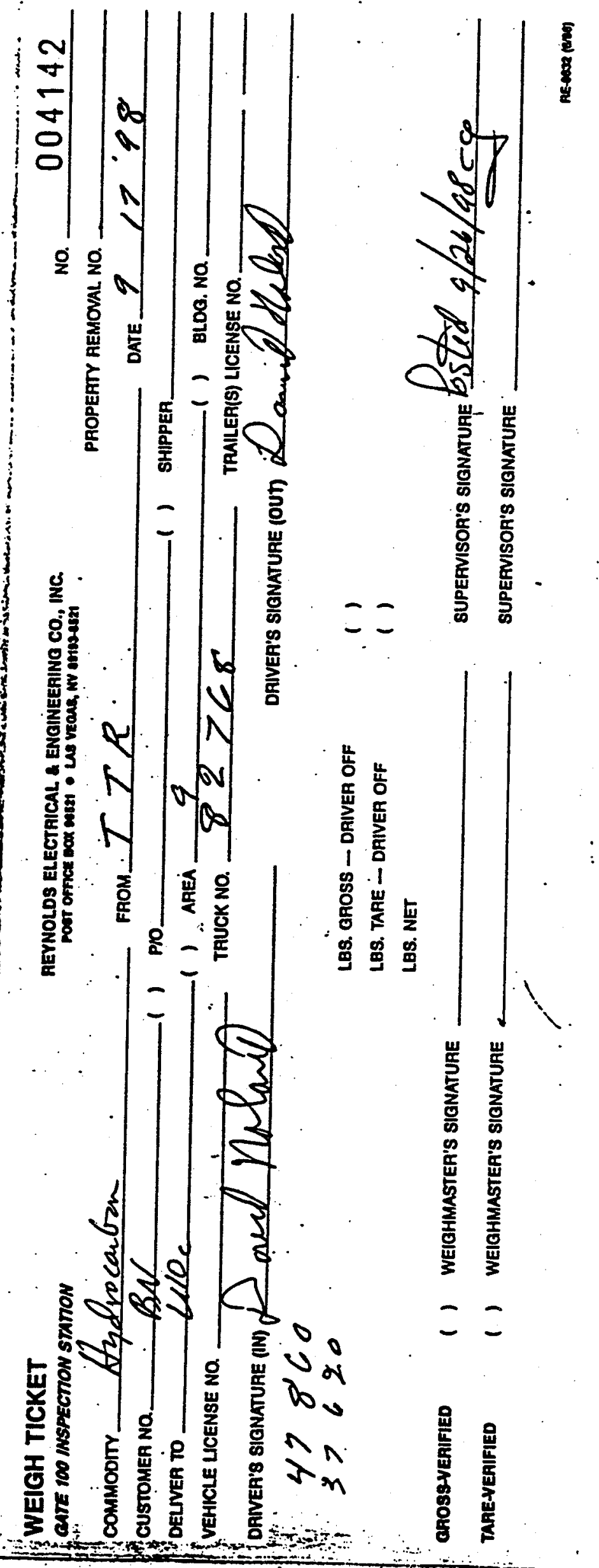




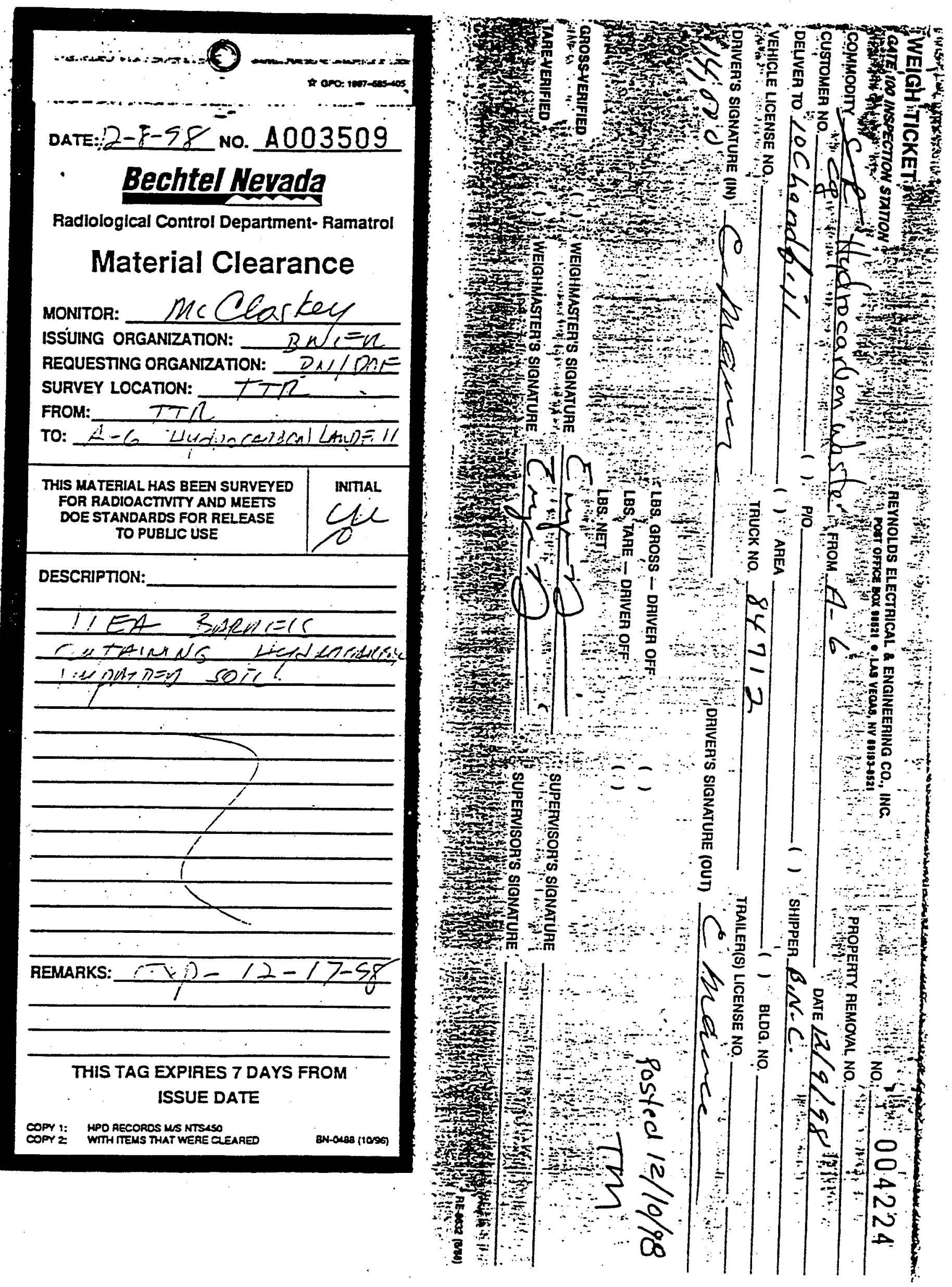




$$
1
$$




\section{WEIGH TICKET}

GATE 100 INSPECTION STATION

REYNOLDS ELECTAICAL ENOINEEAINO CO., ING

CATE noo INSPECTION STATION

соммовir Geci Hzidrocaubon

CUSTOMER NO $B$

DELIVER TO

U1Oc

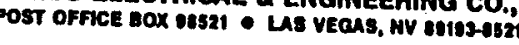

No.

PROPERTY REMOVAL NO

004141

VEHICLE LICENSE NO.

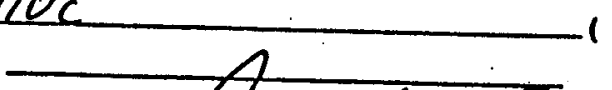

PN G _ DATE $q \quad 189$ DRIVEA'S SIONATUAE (NN) TRUCK Na $\$ 3289$

( ) BLDQ. NO 55808

\section{0}

GROSS-VERIFIED

TAREVEEAIFIED
( ) WEIGHMASTER'S signatufe

( ) WEIGHMASTER'S SIGNATUAE
LBS. GROSS - DRIVER OFF

LBS. TARE - DRIVEA OFF

LBS. NET

DRIVER'S SIGNATURE IOUT

TRAILER(S) LIENSE NO.

11

( )

supervison's sianatuate Posted $9 / 26 / 98$ SUPERVISOR'S SIQNATURE 


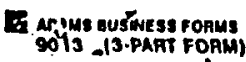

UNIFORM STRAIGHT BILL OF LADING Original-Not Negotiable-Domestic

Carrier

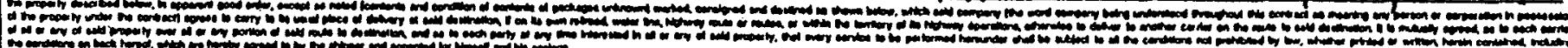
Consigned to Bechtel Nevad a

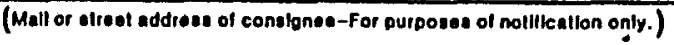

Destination U1OC Landfill, NevadaTest Si te

Routing A Hiy 6, US95 Collect On Dellvery $\$$ Delivering Zip Code NA Vehicle or Car Inilial

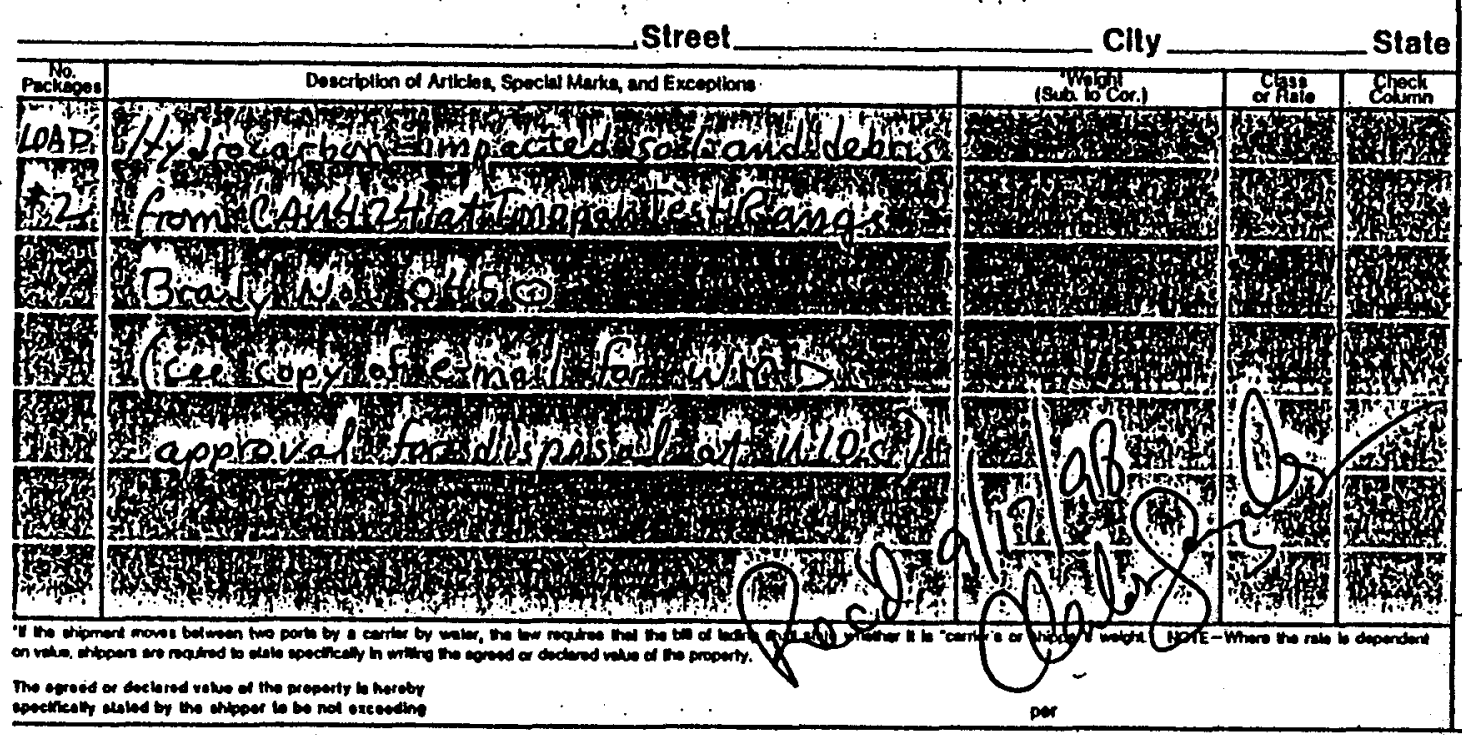

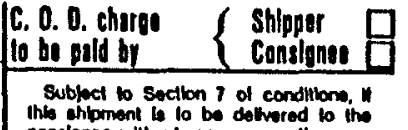

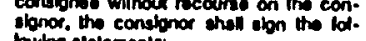
butro stiomentar.

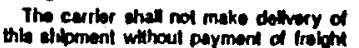

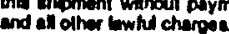
(Shrature of Consionor)

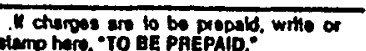
Paceoteds

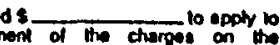
prosedily devecibed heran

Agenl or Cechiou

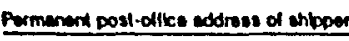

*Shipper, Per Agent, Pe 


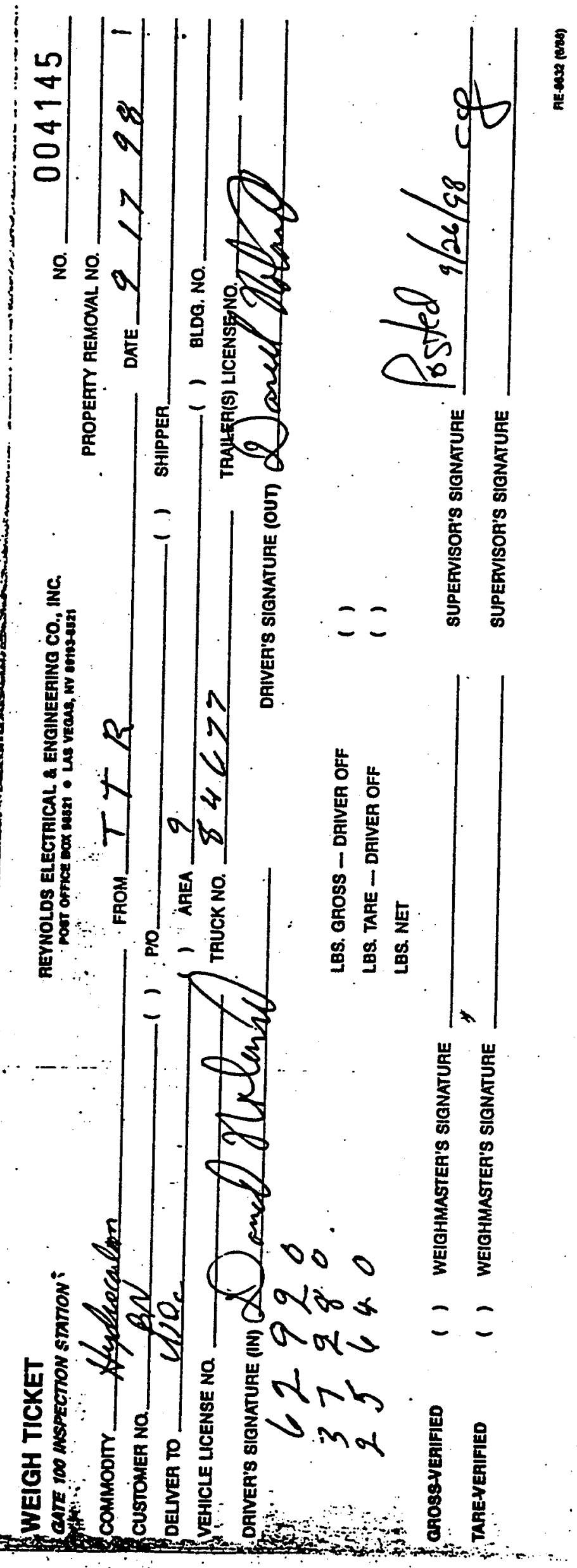




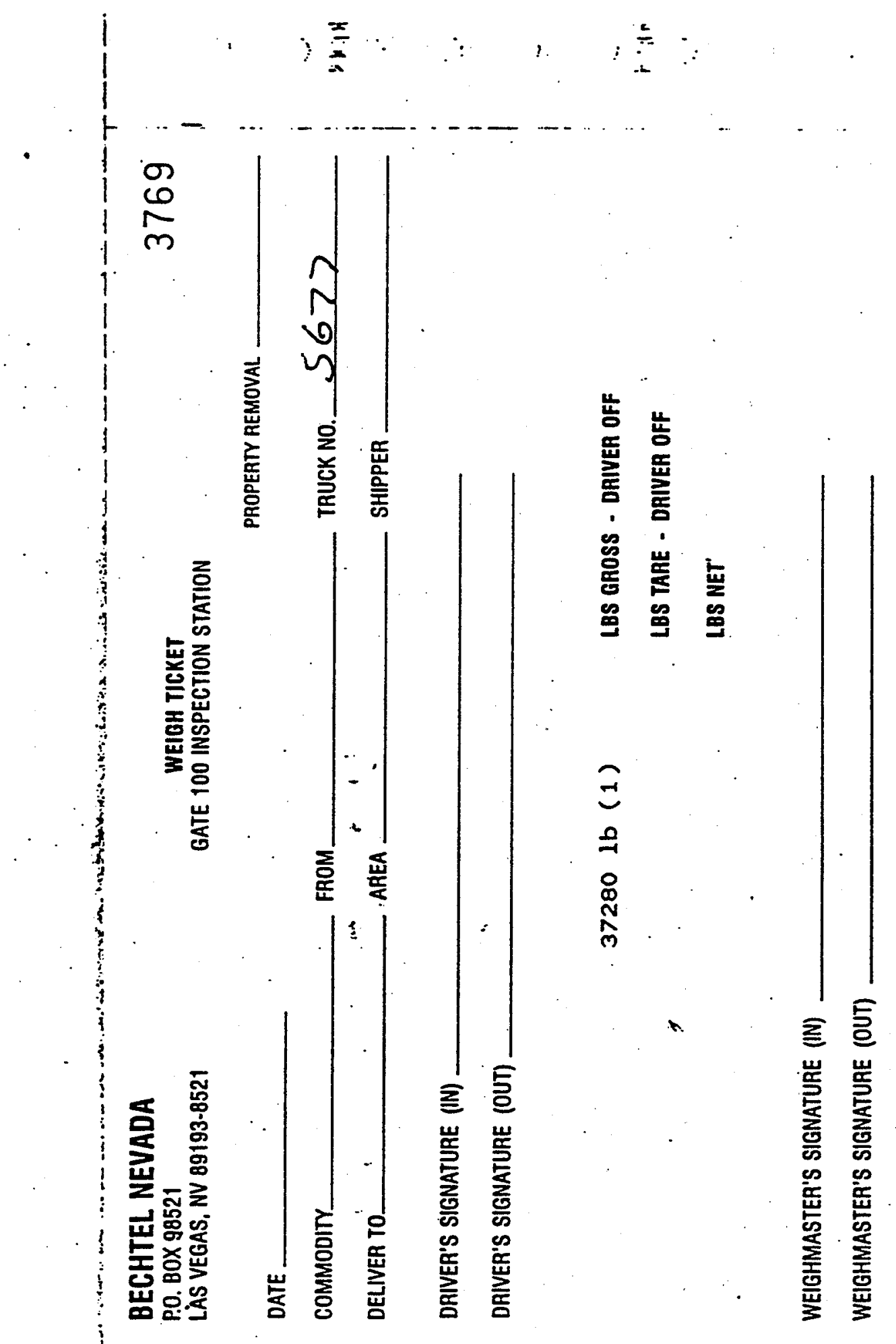




\section{GEOTECHNICAL TEST RESULTS}


October 05, 1998

TRNS : MTL : $001: 99$

David D. Madsen

Bechtel Nevada

P. O. BOX 98521, M/S NST 306

Las Vegas, NV 89193-8521

TONOPAH TEST RANGE AREA 3

As requested, the Materials Testing Laboratory performed Modified Proctor, Gradation, Nuclear Moisture / Density, and Permeability tests. On 07/15/98 Nuclear Moisture / Density tests were taken at 15 different locations. A Proctor sample was also taken at 12 of the 15 locations. A proctor was also run on the sandia borrow pit. Permeability tests were remolded and run on the average Moisture and Density for each location. Permeabilities were also run for the Sandia borrow pit material remolded at $85 \%, 90 \%$, and $95 \%$ optimum density at optimum moisture content. On $07 / 28 / 98$, $07 / 29 / 98,$. and $08 / 13 / 98$ compaction tests were taken on Sandia borrow pit material being placed at various locations. The test locations were designated by Curtis obi. The test results and locations are attached.

If you have any further questions concerning this matter or need additional tests, please contact me at 295-6813.

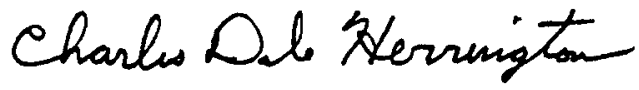

Charles Dale Herrington

Senior Technologist

Enclosures

As Stated

bc: v. Thummala, w/encl.

C. Obi, w/encl.

MTL Files, w/encl. (C4P1CODE) 
APPENDIX

1. NUCLEAR MOISTURE / DENSITY

2. PROCTOR

3. PROCTOR SUMMARY

4. GRADATION

5. GRADATION CURVE

6. COMPACTION TESTS

7. PERMEABILITY

8. LOCATIONS 
NUCLEAR DENSTTY ASTM 02922 200 CAMPBELHOHC2MC-3

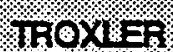

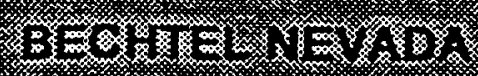

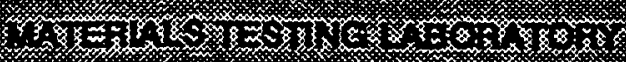

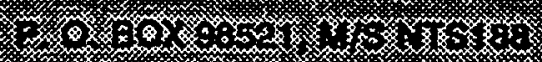

in.
Citto00E

OZTS1960

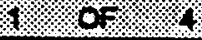

User/Agency BECHTEL

Material

NATIVE

Location of Tests

SEE BELOW

Date Tested 07/15/98 Checked by

D. HERRINGTON
By D. HERRINGTON HOW VERBAL

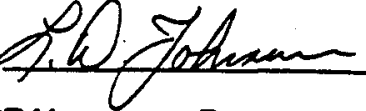

D. Toherman

Information given to CURTIS OBI

LABORATORY NO

TEST LOCATION

DEPTH OF PROBE

DEPTH OF TESTS Below grade

WET DENSITY-PCF

DRY DENSITY-PCF

MOISTURE $\%$

MAXDENSITY-PCF

OPTIMUM MOISTURE \%

PERCENT COMPACTION

\begin{tabular}{|l|l|}
\hline & \\
\hline & \\
\hline & Below grade \\
\hline
\end{tabular}

\begin{tabular}{l|l|l|}
1930 & 1931 & 1932 \\
\hline
\end{tabular}

\begin{tabular}{l|l|l}
$A 3-1 / 1 A$ & $A 3-1 / 1 B$ & $A B-1 / 1 C$
\end{tabular}

BS

BS

BS

Grade

\begin{tabular}{l|l|l|l}
\hline 101.5 & 105.6 & 102.8 & 108 \\
\hline
\end{tabular}

\begin{tabular}{l|l|l|}
97.8 & 100.7 & 98.3 \\
\hline
\end{tabular}

3.8

125.5

9.6

77.9

\begin{tabular}{|r|r|}
\hline 4.8 & 4.6 \\
\hline 125.5 & 125.5 \\
\hline 9.6 & 9.6 \\
\hline 80.2 & 78.3 \\
\hline
\end{tabular}

1938

Date 07/15/98

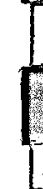

LABORATORY NO

KEST LOCATION

DEPTH OF PROBE

PEPTH OF TESTS Below grade

WET DENSITY-PCF

DRY DENSITY-PCF

MOISTURE $\%$

MAXDENSITY-PCF

DPTIMUM MOISTURE \%

PERCENT COMPACTION

baUGE NO 23205

DATE OF STANDARDIZATION

\begin{tabular}{|c|c|c|c|c|c|c|c|}
\hline 1936 & 1937 & 1938 & & 1939 & 1940 & 1941 & \\
\hline A3-2/1A & A3-2/1B & A3-2/1C & & A3-3/1A & A3-3/1B & A3-3/1C & \\
\hline BS & BS & BS & & BS & BS & BS & \\
\hline Grade & Grade & Grade & AVG & Grade & Grade & Grade & AVG \\
\hline 120.2 & 104.9 & 104.0 & 109.7 & 112.5 & 126.3 & 119.1 & 119.3 \\
\hline 116.3 & 100.9 & 100.2 & 105.8 & 107.3 & 122.9 & 114.9 & 115.0 \\
\hline 3.4 & 3.9 & 3.8 & 3.7 & 4.8 & 2.8 & 3.7 & 3.8 \\
\hline 128.4 & 128.4 & 128.4 & & 125.5 & 125.5 & 125.5 & \\
\hline 8.7 & 8.7 & 8.7 & & 9.5 & 9.5 & 9.5 & \\
\hline 90.6 & 78.6 & 78.0 & 82.4 & 85.5 & 97.9 & 91.6 & 91.7 \\
\hline
\end{tabular}

VALUE OF $M \quad 633$

STANDARDIZATION D 2944

HEMARKS: AVERAGEMOISTURE AND DENSITY WIII BE USEDFOR PERMEABILITY.

BOLD = PROCTOR USED IS NOT FROM SAME AREA

CC: D. MADSEN

BECHTEL MTL BN FILES . 
NUCIEAP DENSTY\%

ASTM .02020, 06

CAMPBEHINO 2MO. 3 $\mathrm{THOX}=\mathrm{an}$

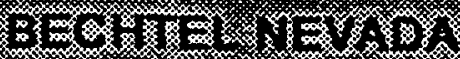

3.

4.

1
CAPICOOE

075108

2. 0 of 1.14

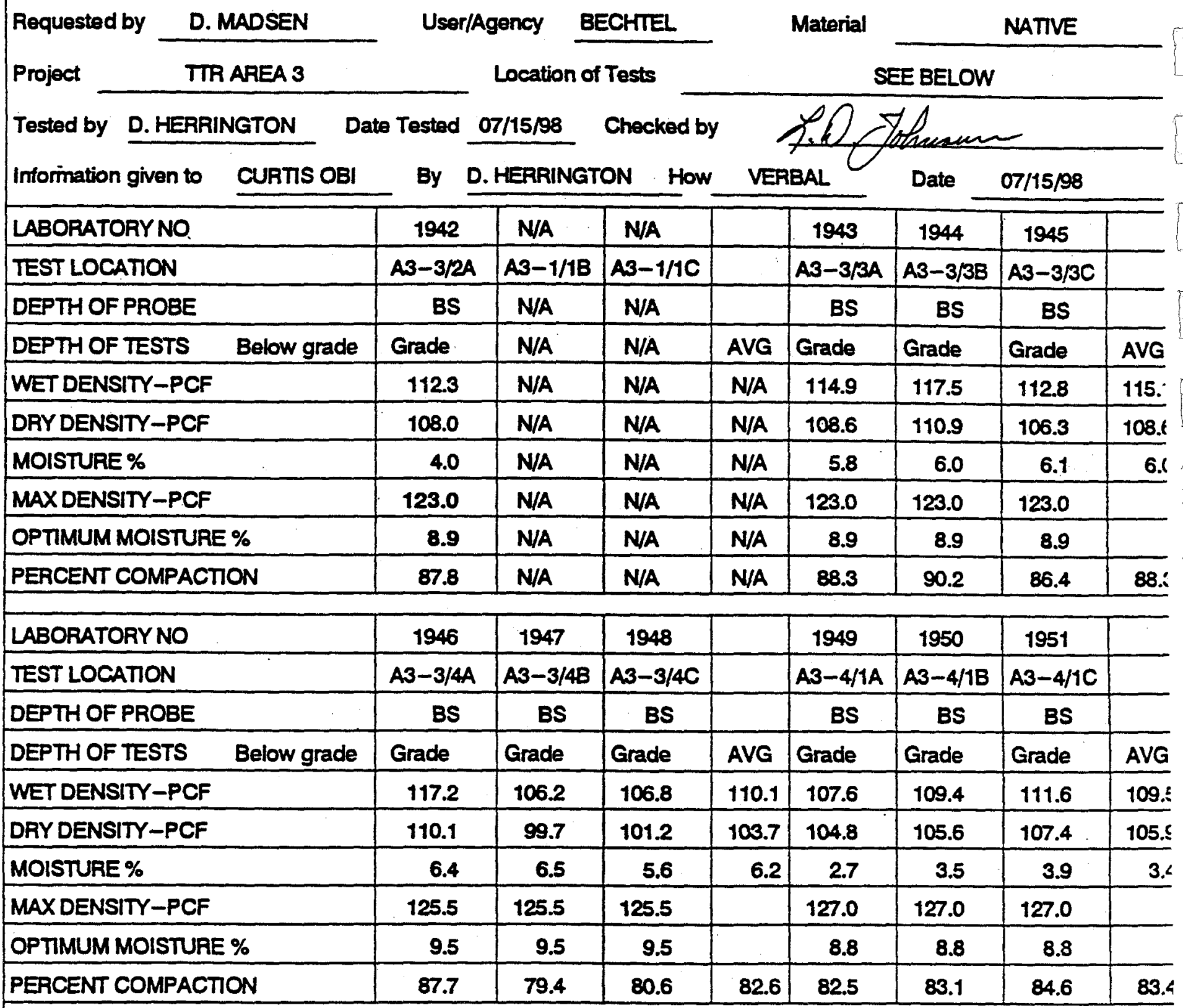

GAUGE NO 23205

DATE OF STANDARDIZATION 07/15/98

VALUEOF M 633

STANDARDIZATION D 2944

REMARKS: AVERAGE MOISTURE AND DENSITY WIIL BE USED FOR PERMEABIITTY.

CC: D. MADSEN BECHTEL BOLD = PROCTOR USED IS NOT FROM SAME AREA MTL BN FILES . 
NUGLEAR DENSTT:

ASTM. 02922, 06

CAMPBELI IMC-2MG-3

THOX:ER of

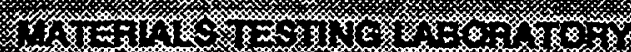

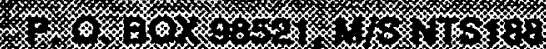

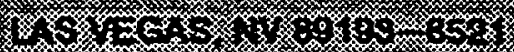

$\mathrm{CP} 1 \mathrm{POOE}$

07P1198:

3. $.0 \mathrm{r} .1 .1 .4$

User/Agency BECHTEL

Material

NATTVE

Location of Tests

SEE BELOW

Project

TTR AREA 3

D. HERRINGTON

Date Tested 07/15/98 Checked by

Tested by

Information given to CURTIS OBI

Information given to CURTIS OBI

By D. HERRINGTON HOW VERBAL

Q.6\% Sthen

\begin{tabular}{|l|l|l|}
\hline 1952 & 1953 & 1954 \\
\hline
\end{tabular}

TEST LOCATION

DEPTH OF PROBE

DE

WE

WET DENSITY-PCF

DRY DENSITY-PCF

MOISTURE \%

MAXDENSITY-PCF

OPTIMUM MOISTURE \%

PERCENT COMPACTION

\begin{tabular}{c|c|c|}
\hline$A 3-4 / 2 A$ & $A 3-4 / 2 B$ & $A 3-4 / 2 C$ \\
\hline$B S$ & $B S$ & $B S$
\end{tabular}

Date $\quad 07 / 15 / 98$

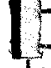

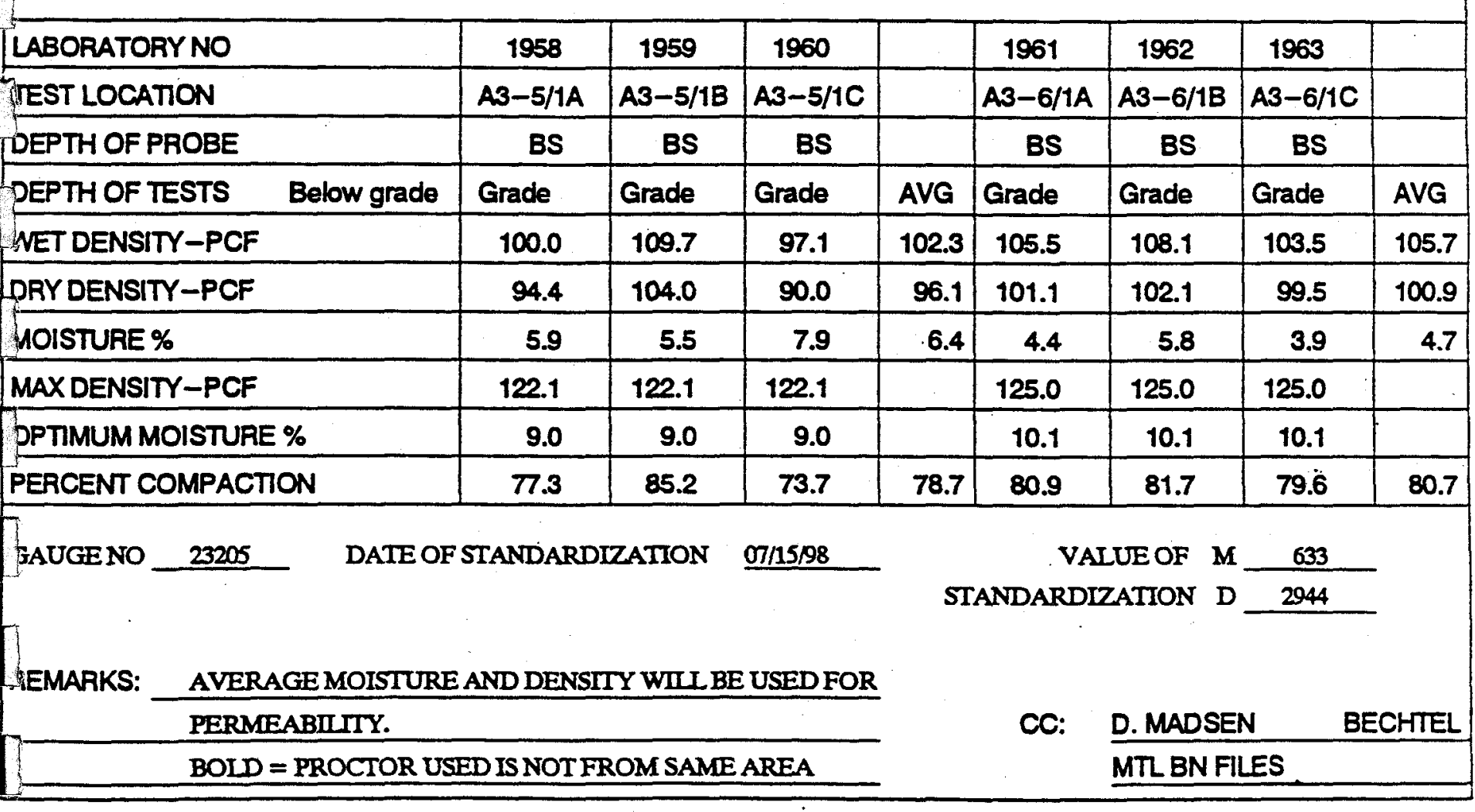




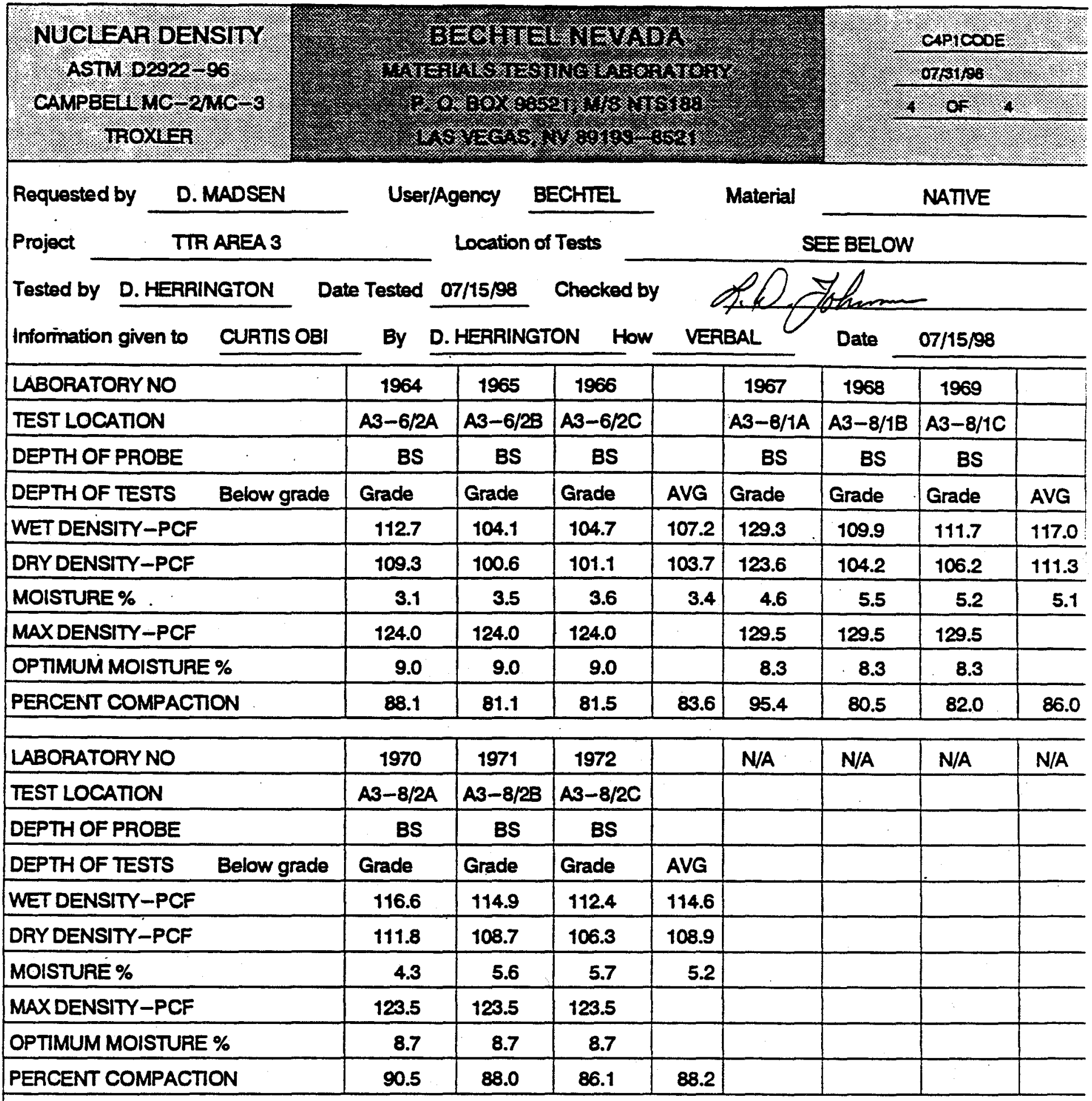

GAUGENO

DATE OF STANDARDIZATION

VAIUE OF $M$ STANDARDIZATION D 2944

REMARKS: AVERAGE MOISTURE AND DENSTTY WIILL BE USED FOR PERMEABIITYY.

BOLD $=$ PROCTOR USED IS NOT FROM SAME AREA
CC: D. MADSEN BECHTEL MTL BN FILES




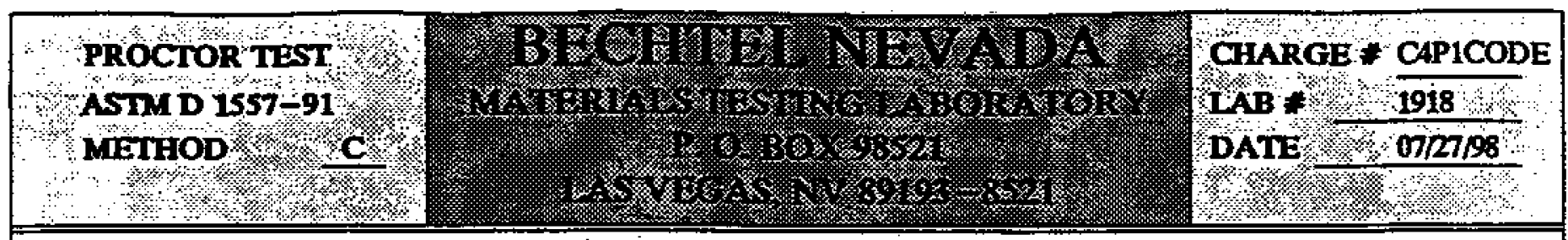

Project:

TIR AREA 3

Sampled by: D. HERRINGTON

Tested by:
Requested by: D. MADSEN
User/Agency: BECHIEI Date sompled $07 / 15 / 98$ Material: A3-1/1 A,B,C D. HERRINGTON Date tested $07 / 25 / 98$ Checked by:

\begin{tabular}{|c|c|c|c|c|c|c|c|}
\hline \multicolumn{2}{|r|}{ TRIAI } & 1 & 2 & 3 & 4 & 5 & $\overline{6}$ \\
\hline 1 & Whmold + wet soid & 7525.6 & 74563 & 74445 & 7202.4 & N/A & N/A \\
\hline 2 & Wh mold & 28433 & 2843.3 & 28433 & 28433 & N/A & $\mathbf{N} / \mathbf{A}$ \\
\hline 3 & Wh wet soil & 46823 & 4613.0 & 46012 & 4359.1 & $\mathbf{N} / \mathbf{A}$ & N/A \\
\hline 4 & Wer Density, PCF & 137.6 & 135.6 & 135.3 & 128.1 & $\mathbf{N} / \mathbf{A}$ & N/A \\
\hline 5 & Moisture Tare & 1120 & 112.0 & 113.0 & 127.0 & $\mathbf{N} / \mathbf{A}$ & N/A \\
\hline 6 & Wh wet soil + tare & 12025 & 1290.8 & 1400.1 & 1297.4 & N/A & N/A \\
\hline 7 & Wh dry soil + tare & 1088.4 & 1148.7 & 1289.8 & 1215.6 & N/A & N/A \\
\hline 8 & Wh moisture & 114.1 & 1421 & 1103 & 81.8 & $\mathbf{N} / \mathbf{A}$ & $\mathbf{N} / \mathbf{A}$ \\
\hline 9 & Wh tare & 16.9 & 17.0 & 16.9 & 173 & N/A & N/A \\
\hline 10 & Wh dry soil & 1071.5 & 1131.7 & 12729 & 11983 & N/A & N/A \\
\hline 11 & * Mointere & 10.6 & 12.6 & 8.7 & 6.8 & N/A & $\mathbf{N} / \mathbf{A}$ \\
\hline 12 & Dry Deasity, PCF & 124.4 & 120.5 & 124.5 & 119.9 & $\mathbf{N} / \mathbf{A}$ & $\mathbf{N} / \mathbf{A}$ \\
\hline
\end{tabular}

12 Dry Deasity, PCF

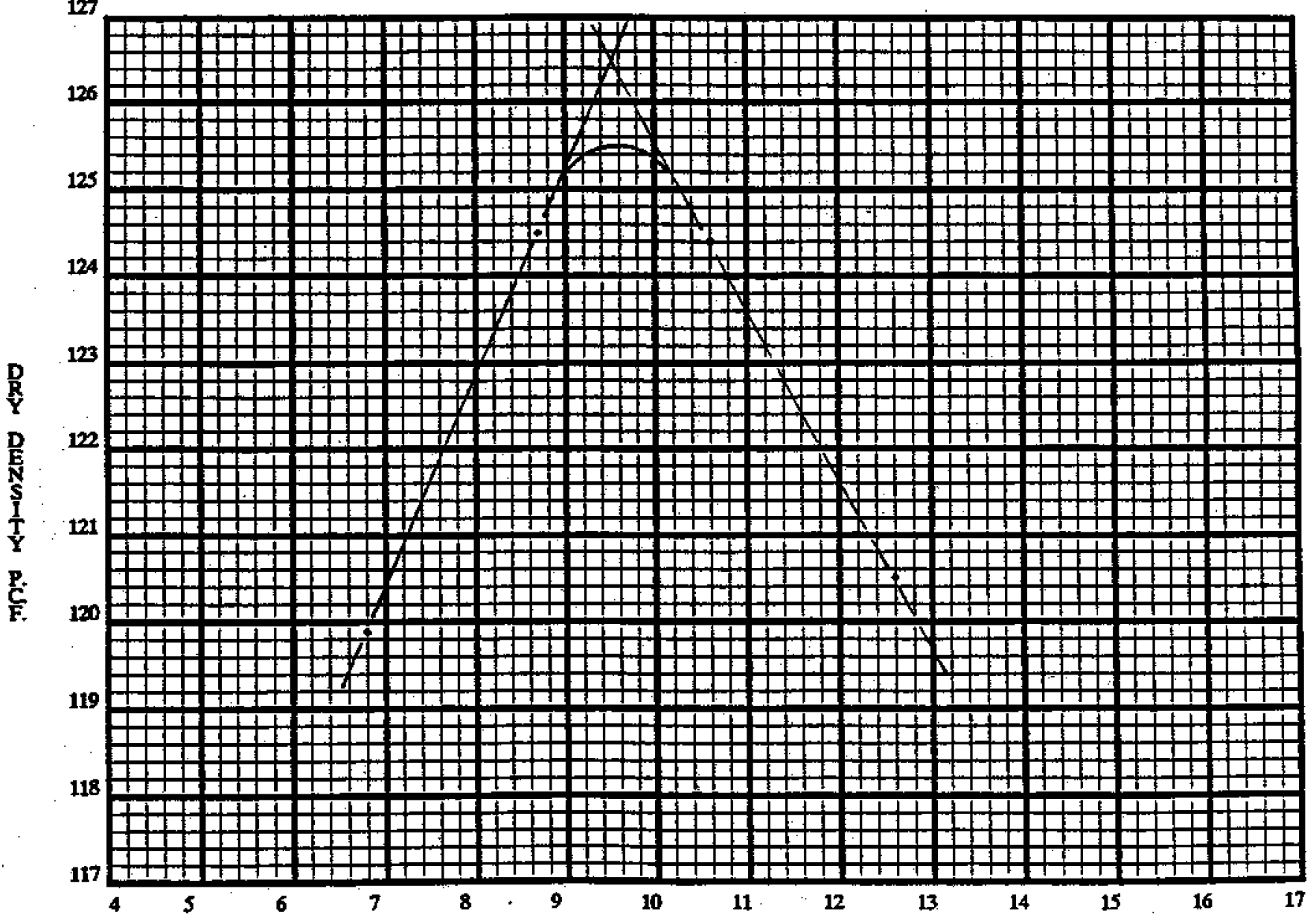

MAX. DENSTTY $=125.5$ PCF $\cdot$ MOISTURE CONTENT\%

OPT. MOISTURE $=\frac{9.6}{9}$ 


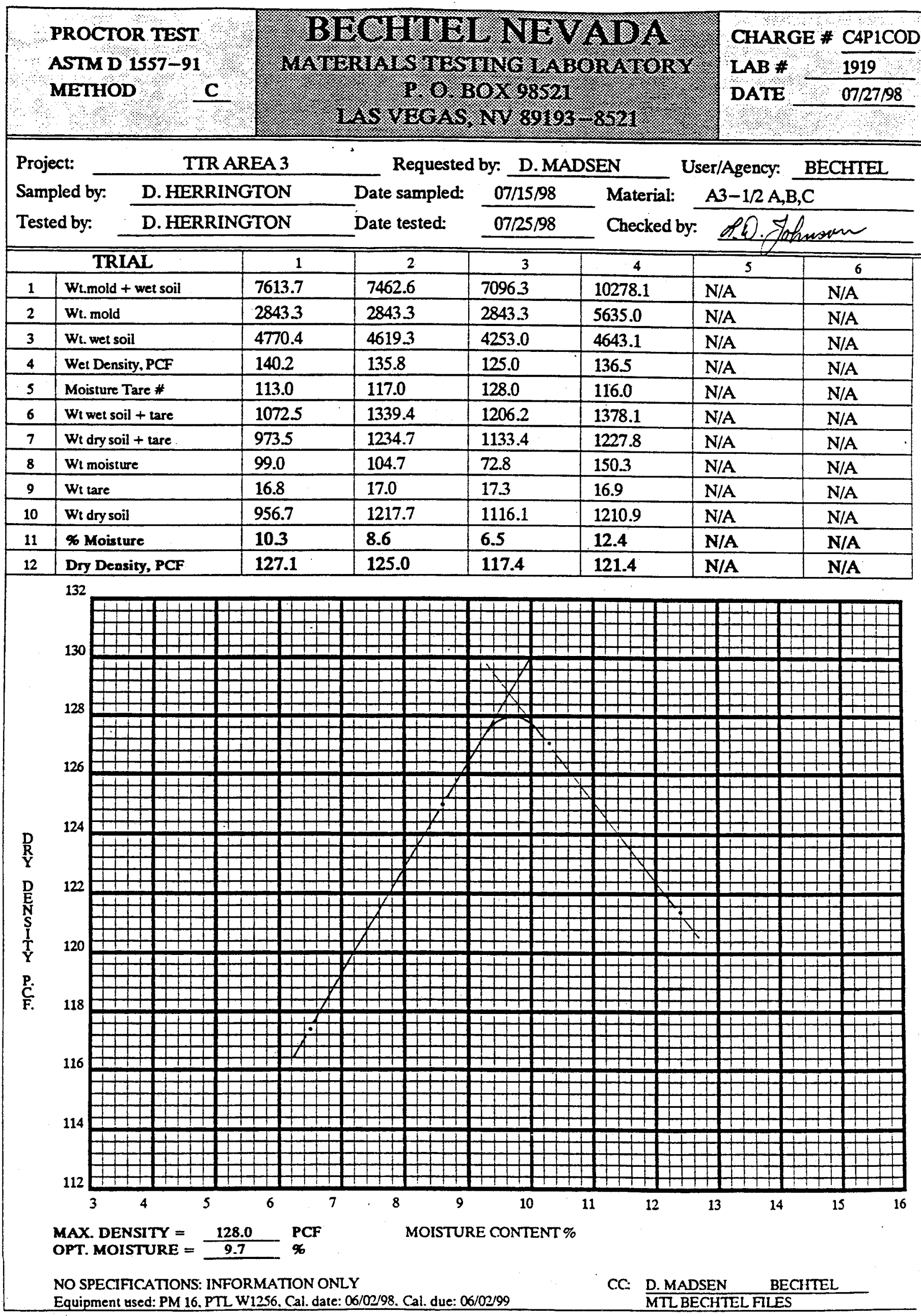




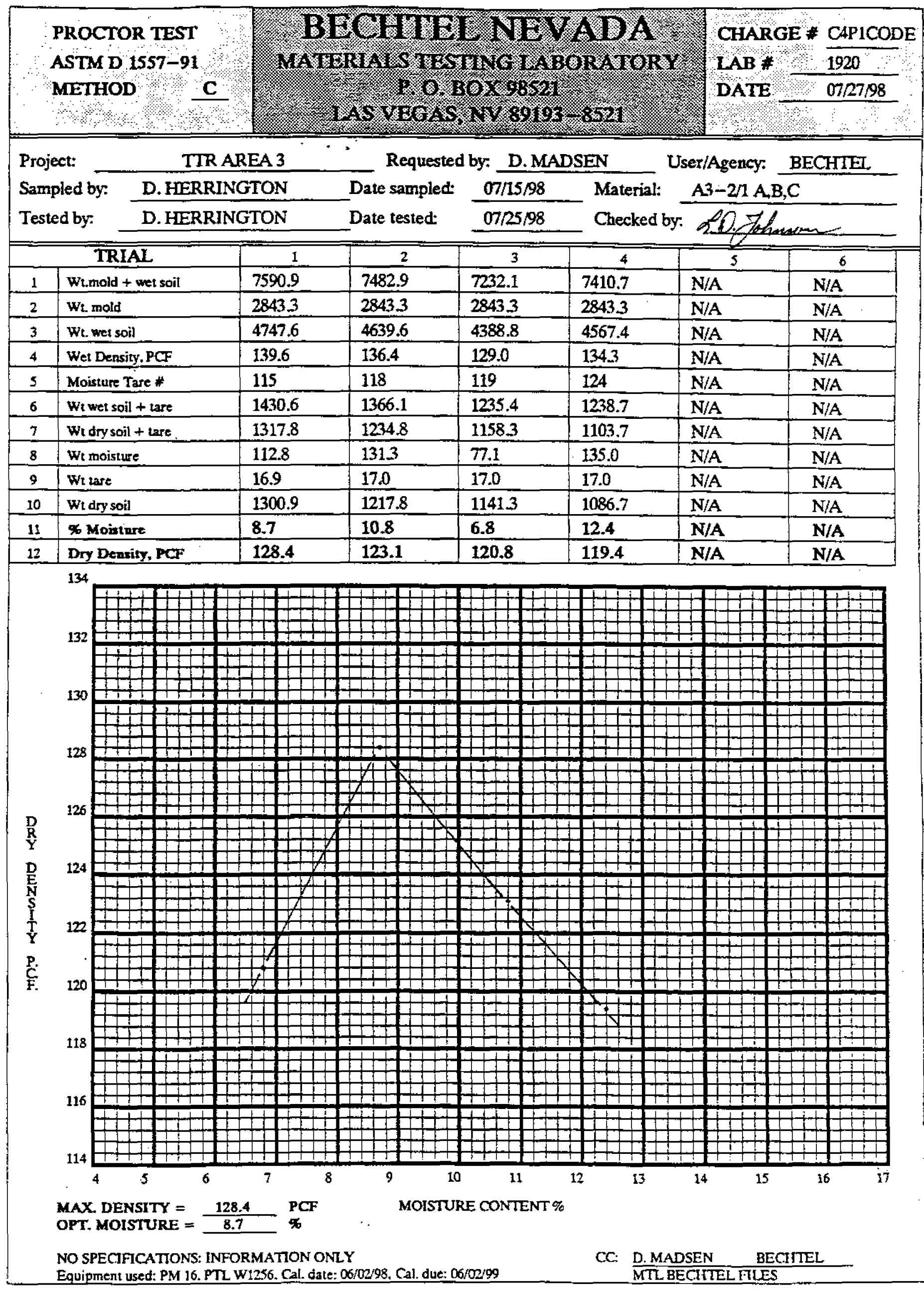




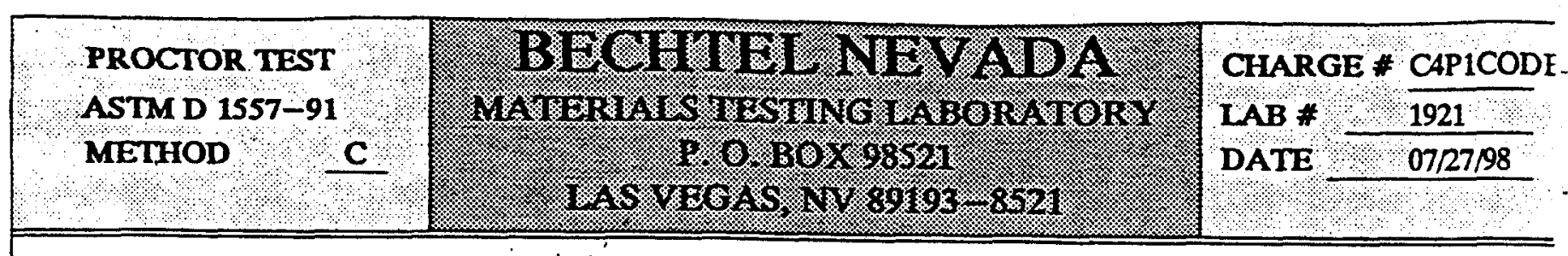

Project: TTR AREA 3

Requested by: D.MADSEN

User/Agency: BECHTEL

Sampled by: D. HERRINGTON Date sampled: $07 / 15 / 98 \quad$ Material: $\quad$ A3-3B A,B,C

Tested by: D. HERRINGTON Date tested: $07 / 25 / 98$ Checked by: R. Tohom

\begin{tabular}{|c|c|c|c|c|c|c|c|}
\hline \multicolumn{2}{|r|}{ TRIAL } & 1 & 2 & 3 & 4 & 5 & 6 \\
\hline 1 & Wt.mold + wet soil & 72013 & 7404.7 & 6834.9 & 7367.3 & N/A & N/A \\
\hline 2 & Wt.mold & 28433 & 2843.3 & 2843.3 & 2843.3 & N/A & N/A \\
\hline 3 & Wh. wet soil & 4358.0 & 4561.4 & 3991.6 & 4524.0 & N/A & N/A \\
\hline 4 & Wot Density, PCF & 128.1 & 134.1 & 1173 & 133.0 & $N / A$ & N/A \\
\hline 5 & Moisture Tare \# & 116 & 120 & 122 & 125 & N/A & N/A \\
\hline 6 & Wt wet soil + tare & 1260.7 & 1625.8 & 1243.5 & 1371.1 & N/A & N/A \\
\hline 7 & Wi dry soil + tare & 1172.6 & 1482.7 & 1175.8 & 1227.3 & $\mathrm{~N} / \mathrm{A}$ & N/A \\
\hline 8 & Wt moisture & 88.1 & 143.1 & 67.7 & 143.8 & $\mathrm{~N} / \mathrm{A}$ & N/A \\
\hline 9 & Wt lare & 16.9 & 17.2 & 17.1 & 17.1 & $N / A$ & N/A \\
\hline 10 & Wi dry soil & 1155.7 & 1465.5 & 1158.7 & 1210.2 & N/A & N/A \\
\hline 11 & \% Moisture & 7.6 & 9.8 & 5.8 & 11.9 & N/A & N/A \\
\hline 12 & Dry Density, PCF & 119.0 & 122.2 & 110.9 & 118.9 & N/A & N/A \\
\hline
\end{tabular}

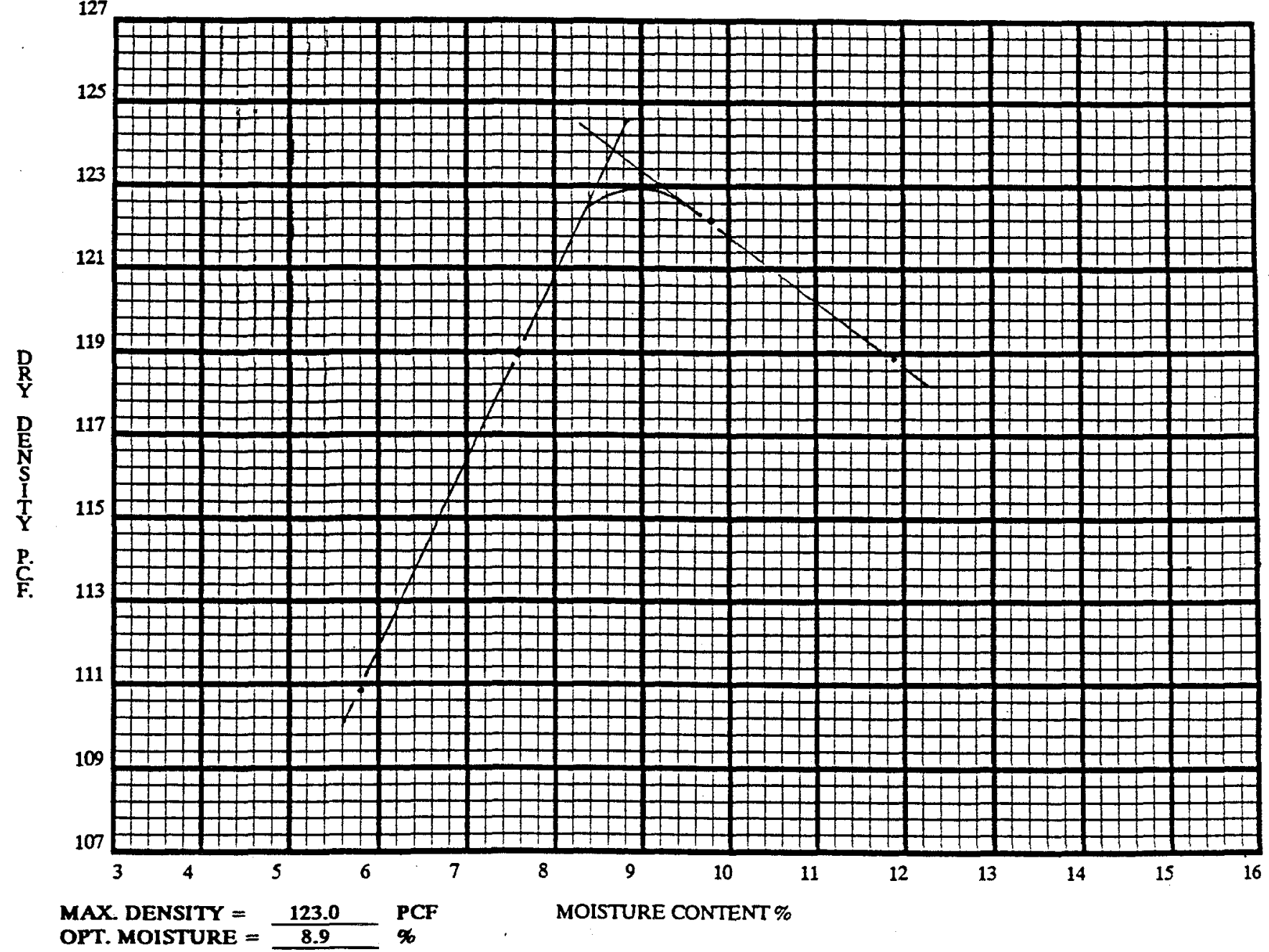

NO SPECIFICATIONS: INFORMATION ONLY

Equipment used: PM 16. PTL W1256. Cal. date: 06/02/98. Cal. due: 06/00/99

CC: D. MADSEN BECFTEL MTLBECHTELFILES 


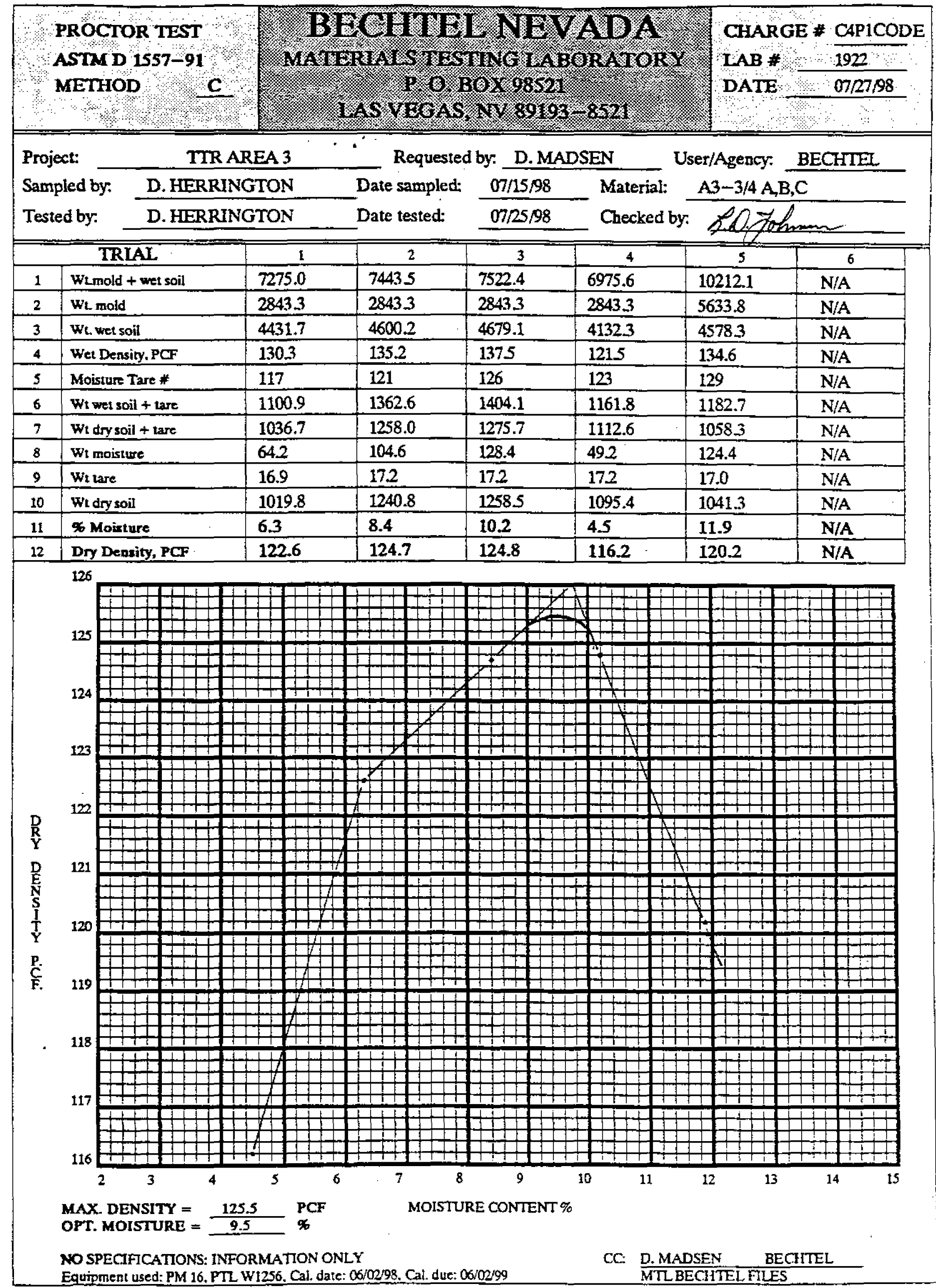




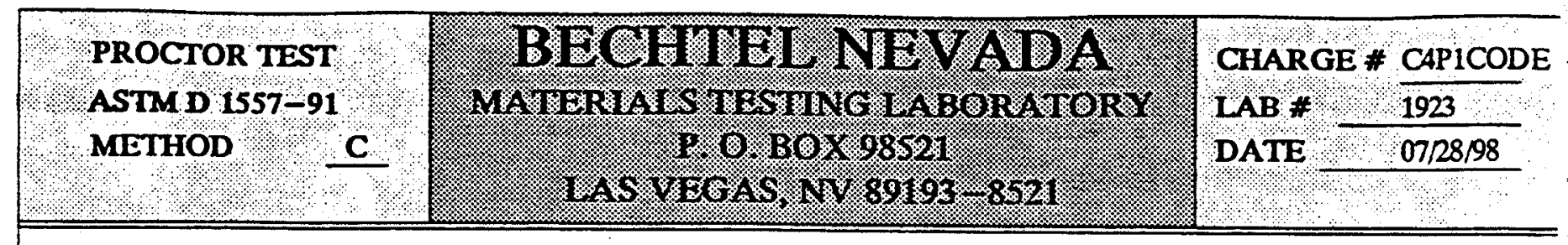

Project:

TTR AREA 3

Requested by: D. MADSEN

User/Agency: BECHTEL

Sampled by: D. HERRINGTON Date sampled: $07 / 15 / 98$ Material: $\quad$ A3-4/1 A,B,C

Tested by: D.HERRINGTON Date tested: 07/28/98 Checked by: W0.70hmm

\begin{tabular}{|c|c|c|c|c|c|c|c|}
\hline \multicolumn{2}{|r|}{ TRIAL } & 1 & 2 & 3 & 4 & 5 & 6 \\
\hline 1 & Wt.mold + wet soil & 7307.6 & 75453 & 7501.9 & 7025.0 & 10227.9 & N/A \\
\hline 2 & Wt.mold & 2843.3 & 2843.3 & 2843.3 & 2843.3 & 5633.8 & N/A \\
\hline 3 & Wt. wet soil & 4464.3 & 4702.0 & 4658.6 & 4181.7 & 4594.1 & N/A \\
\hline 4 & Wet Density, PCF & 131.2 & 138.2 & 136.9 & 122.9 & 135.0 & N/A \\
\hline 5 & Moisture Tare \# & A & $\mathrm{H}$ & 114 & 114 & 113 & N/A \\
\hline 6 & Wt wet soil + tare & 1166.1 & 1298.3 & 1219.3 & 1074.2 & 1442.1 & N/A \\
\hline 7 & Wt dry soil + tare & 1089.3 & 1189.8 & 1096.8 & 1019.7 & 1278.1 & N/A \\
\hline 8 & Wt moisture & 76.8 & 108.5 & 122.5 & 54.5 & 164.0 & N/A \\
\hline 9 & Wt tare & 16.8 & 16.9 & 16.9 & 17.0 & 16.9 & N/A \\
\hline 10 & Wt dry soil & 1072.5 & 1172.9 & 1079.9 & 1002.7 & 1261.2 & N/A \\
\hline 11 & \%o Moisture & 7.2 & 9.3 & 11.3 & 5.4 & 13.0 & N/A \\
\hline 12 & Dry Density, PCF & 122.5 & 126.5 & 123.0 & 116.6 & 119.5 & N/A \\
\hline
\end{tabular}

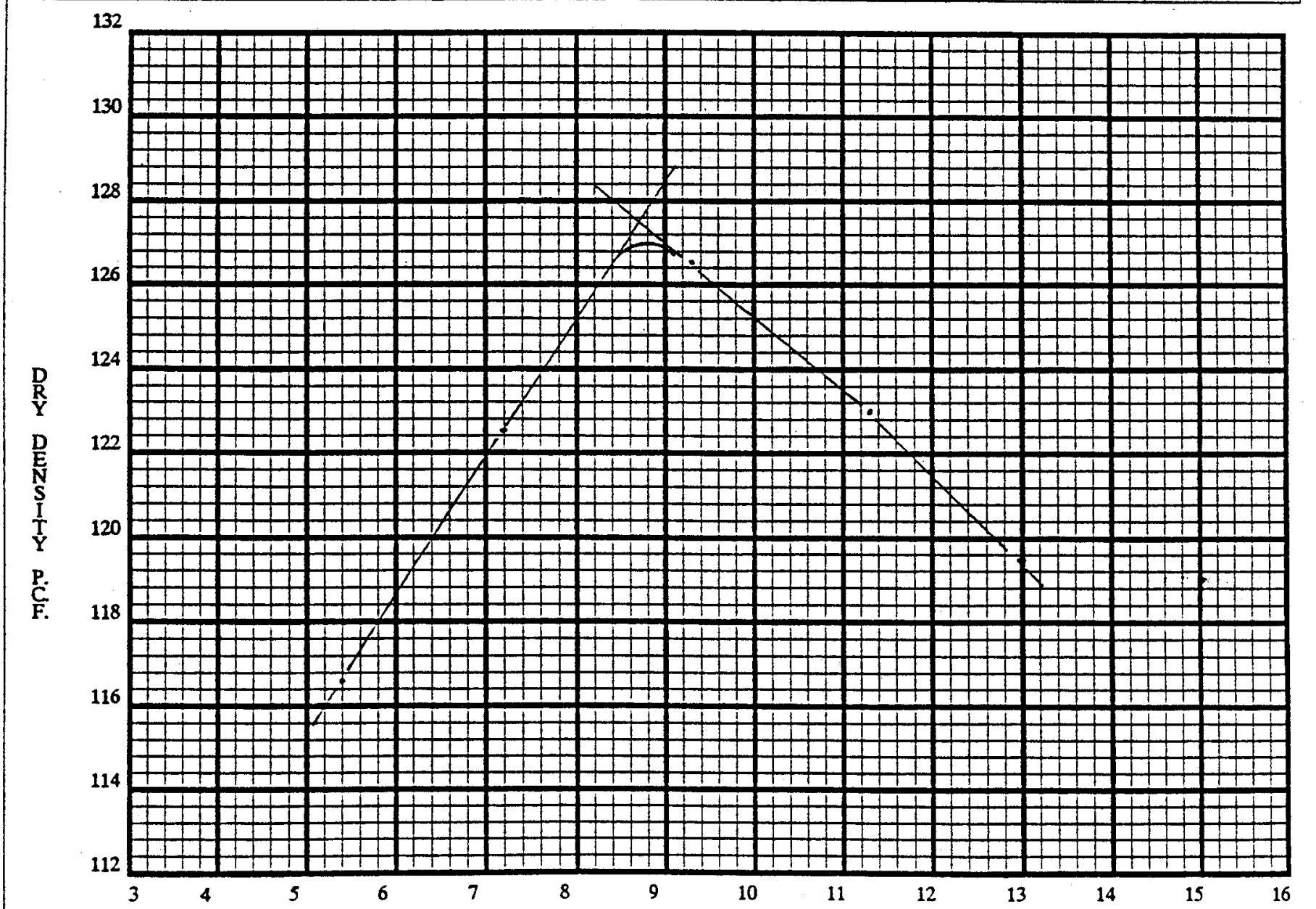

MAX. DENSITY $=127.0$ PCF MOISTURE CONTENT\%

OPT. MOISTURE $=\frac{127.0}{8.8} \%$

NO SPECIFICATIONS: INFORMATION ONLY

Equipment used: PM 16. PTL W1256. Cal. datc: 06/02/98. Cal. due: 06/00/99

CC: D. MADSEN BECHTEL MTLBECHTELFILES 


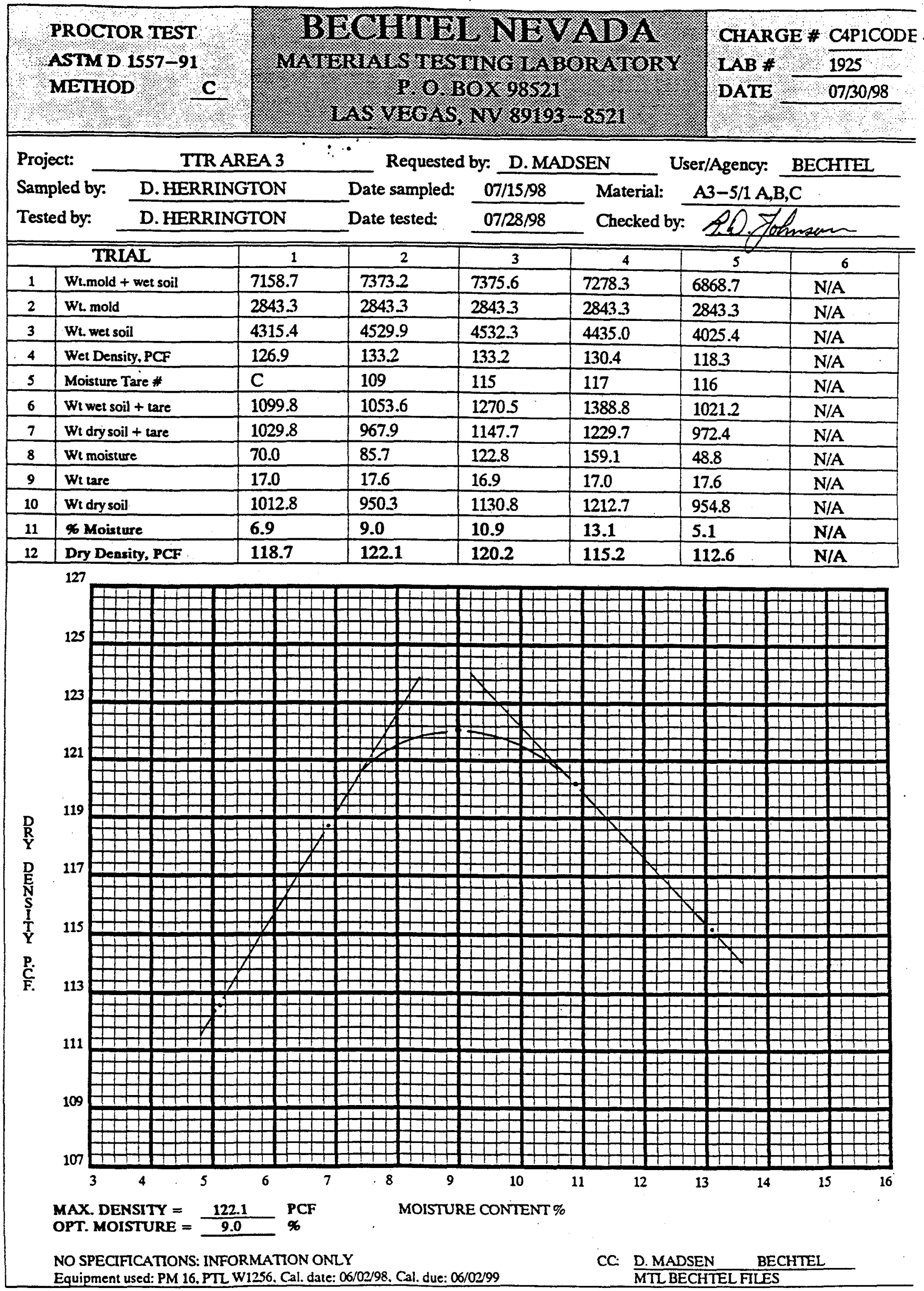




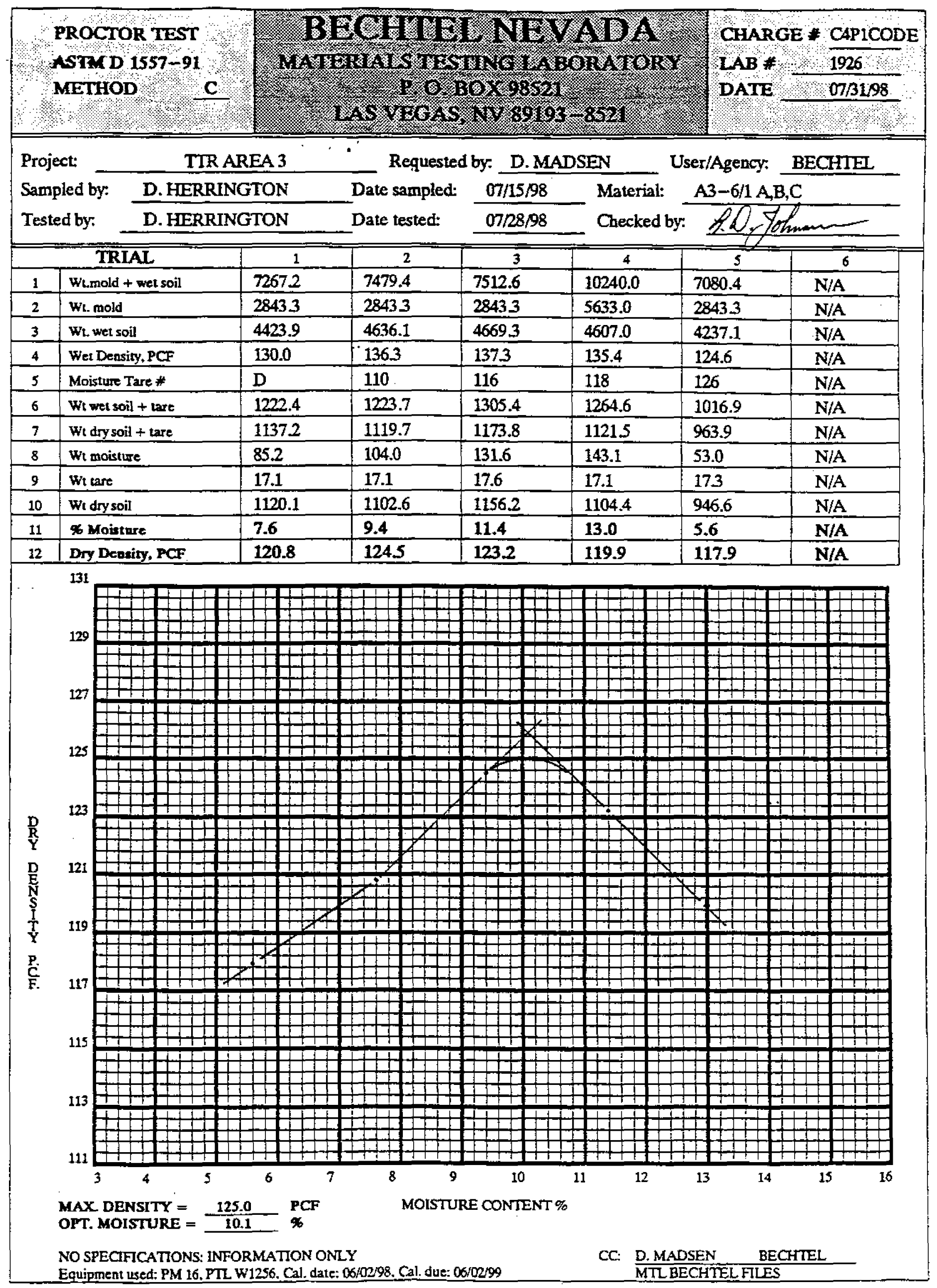




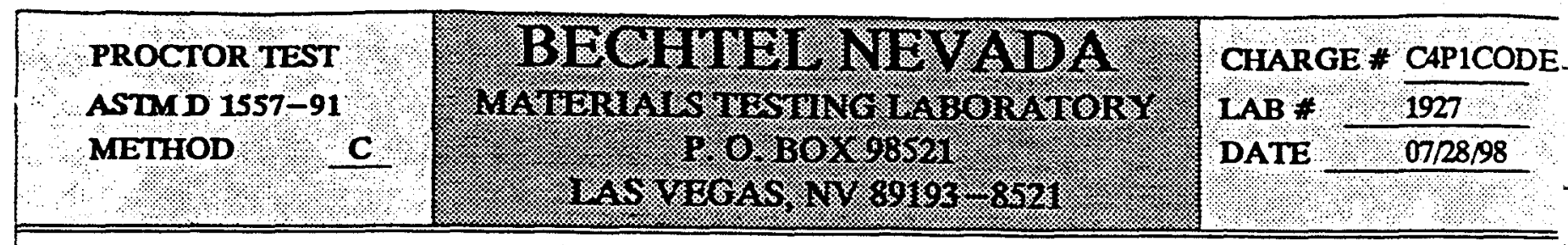

\begin{tabular}{|c|c|c|c|c|c|c|c|c|}
\hline \multirow{3}{*}{\multicolumn{2}{|c|}{$\begin{array}{l}\text { Project: } \\
\text { Sampled by: } \\
\text { Tested by: }\end{array}$}} & \multicolumn{2}{|c|}{ TIR AREA 3} & \multicolumn{3}{|c|}{ Requested by: D.MADSEN } & \multirow{2}{*}{$\begin{array}{l}\text { User/Agency: } \\
\qquad \text { A3-6/2 A,B }\end{array}$} & BECHTEL \\
\hline & & \multirow{2}{*}{\multicolumn{2}{|c|}{$\begin{array}{l}\text { D. HERRINGTON } \\
\text { D. HERRINGTON }\end{array}$}} & \multirow{2}{*}{$\begin{array}{l}\text { Date sampled: } \\
\text { Date tested: }\end{array}$} & \multirow{2}{*}{$\frac{07 / 15 / 98}{07 / 28 / 98}$} & \multirow{2}{*}{$\begin{array}{l}\text { Material: } \\
\text { Checked b }\end{array}$} & & \\
\hline & & & & & & & 20 & \\
\hline \multicolumn{3}{|c|}{ TRIAL } & 1 & 2 & 3 & 4 & 5 & 6 \\
\hline 1 & \multicolumn{2}{|c|}{ Wt.mold + wet soil } & 7362.6 & 74473 & 7096.0 & 7382.0 & N/A & $\mathrm{N} / \mathrm{A}$ \\
\hline 2 & \multicolumn{2}{|c|}{ Wh. mold } & 2843.3 & 28433 & 2843.3 & 2843.3 & N/A & N/A \\
\hline 3 & \multicolumn{2}{|c|}{ Wt. wet soil } & 4519.3 & 4604.0 & 4252.7 & 4538.7 & N/A & N/A \\
\hline 4 & \multicolumn{2}{|c|}{ Wet Density, PCF } & 132.8 & 135.3 & 125.0 & 133.4 & N/A & N/A \\
\hline 5 & \multicolumn{2}{|c|}{ Moisture Tare \# } & $\mathbf{E}$ & 111 & 108 & 119 & N/A & $\mathrm{N} / \mathrm{A}$ \\
\hline 6 & \multicolumn{2}{|c|}{ Wt wet soil + tare } & 1214.4 & 1185.0 & 1126.1 & 1352.2 & N/A & $\overline{N / A}$ \\
\hline 7 & \multicolumn{2}{|c|}{ Wt dry soil + tare } & 1125.0 & 1077.0 & 1061.6 & 1206.3 & N/A & N/A \\
\hline 8 & \multicolumn{2}{|c|}{ Wi moisture } & 89.4 & 108.0 & 64.5 & 145.9 & N/A & N/A \\
\hline 9 & \multicolumn{2}{|c|}{ Wh tare } & 17.0 & 17.0 & 17.5 & 17.1 & N/A & N/A \\
\hline 10 & \multicolumn{2}{|c|}{ Wt dry soil } & 1108.0 & 1060.0 & 1044.1 & 1189.2 & N/A & N/A \\
\hline 11 & \multicolumn{2}{|c|}{ \% Moisture } & 8.1 & 10.2 & 6.2 & 12.3 & $\mathbf{N} / \mathbf{A}$ & N/A \\
\hline 12 & \multicolumn{2}{|c|}{ Dry Density, PCF } & 122.9 & 122.8 & 117.7 & 118.8 & N/A & N/A \\
\hline
\end{tabular}

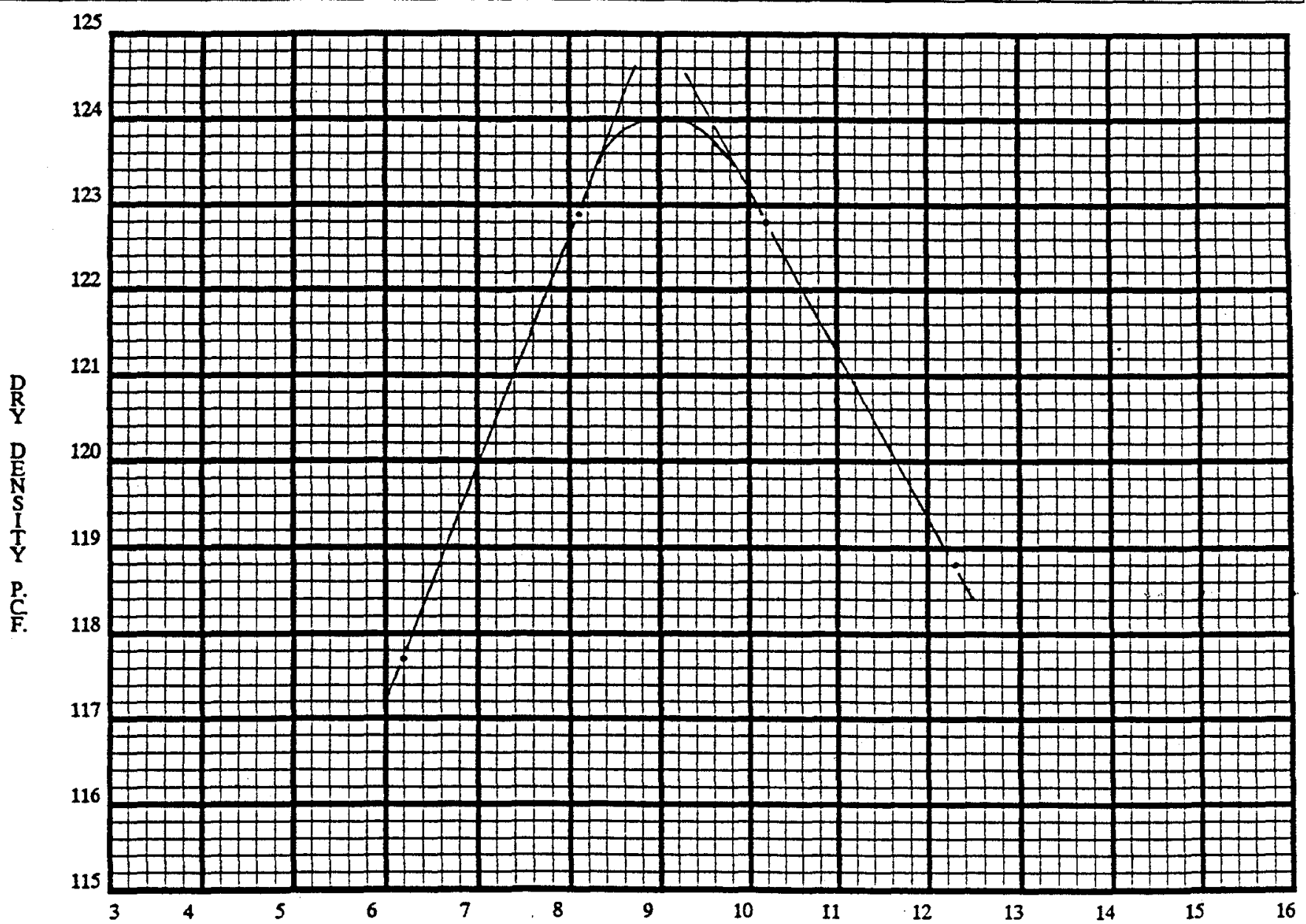

MAX. DENSITY $=124.0 \quad$ PCF MOISTURE CONTENT \%

OPI MOISTURE $=\frac{124.0}{9.0} \%$

NO SPECIFICATIONS: INFORMATION ONLY

Equipment used: PM 16. PTL W1256. Cal. date: 06/02/98. Cal. due: 06/02/99

CC: D. MADSEN BECHTEL MTL BECHTELFILES 


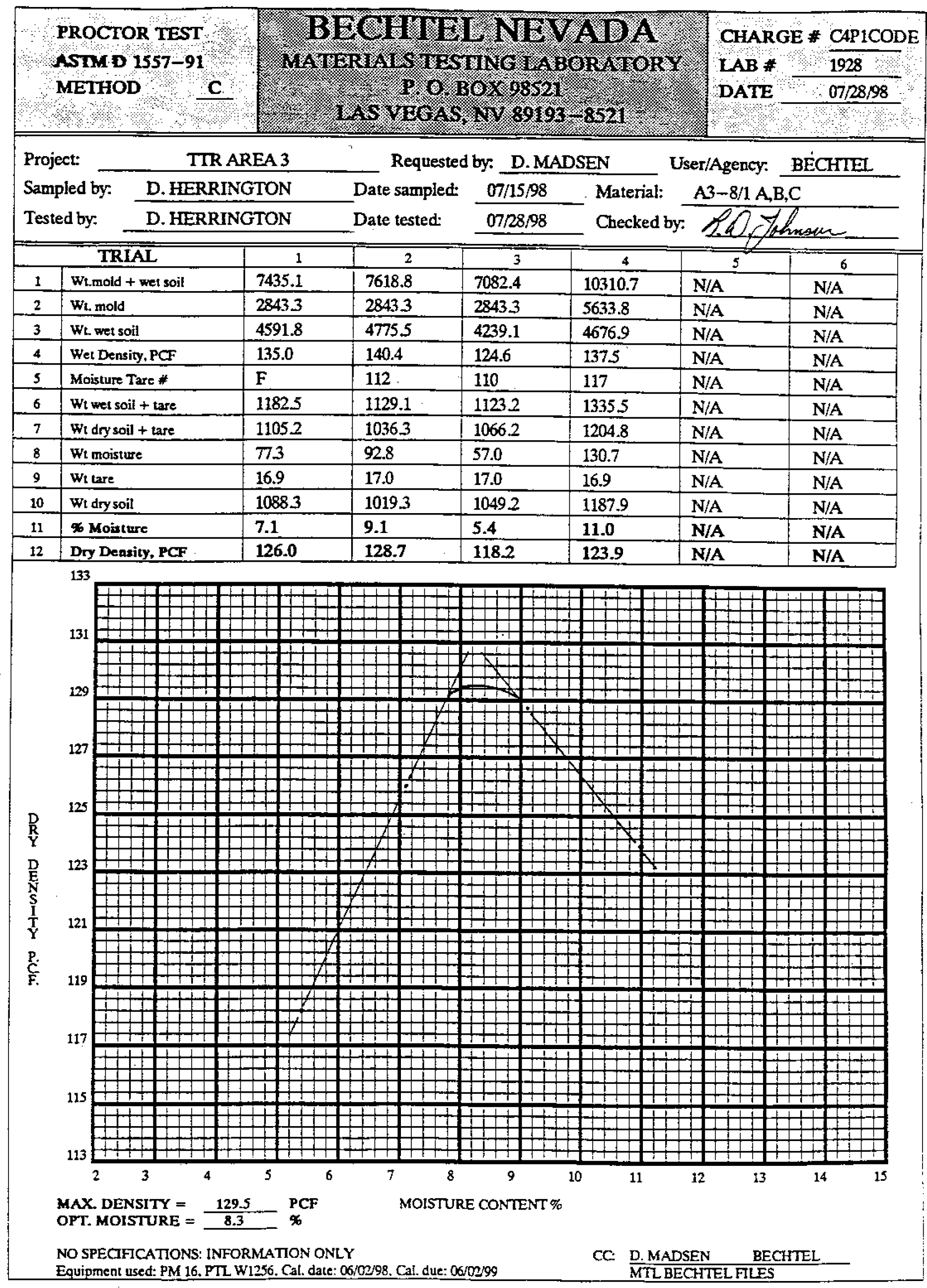




\begin{tabular}{|c|c|c|c|c|}
\hline $\begin{array}{l}\text { PROCTOF } \\
\text { ASTM D } 1\end{array}$ & & 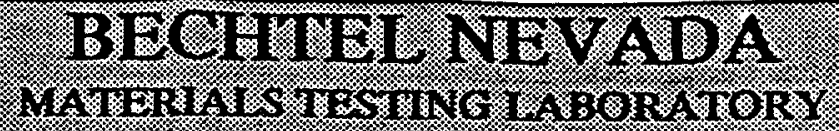 & CHARGE \# & CAP1CODE \\
\hline METHOD & $\mathrm{C}$ & 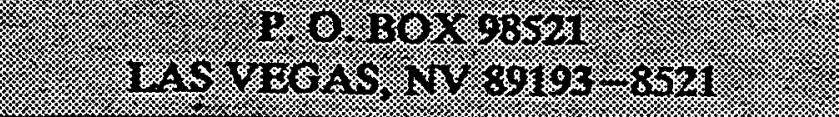 & DATE & $07 / 30 / 98$ \\
\hline
\end{tabular}

\begin{tabular}{|c|c|c|c|c|c|c|c|c|}
\hline \multirow{3}{*}{\multicolumn{2}{|c|}{$\begin{array}{l}\text { Project: } \\
\text { Sampled by: } \\
\text { Tested by: }\end{array}$}} & \multicolumn{2}{|c|}{ TIR AREA 3} & \multicolumn{3}{|c|}{ D. MADSEN } & \multirow{2}{*}{$\begin{array}{l}\text { User/Agency: } \\
\text { A3-8/2 A,E }\end{array}$} & BECHTEI \\
\hline & & \multirow{2}{*}{\multicolumn{2}{|c|}{$\frac{\text { D. HERRINGTON }}{\text { D. HERRINGTON }}$}} & \multirow{3}{*}{$\begin{array}{l}\text { Date sampled: } \\
\text { Date tested: } \\
\text { [ }\end{array}$} & \multirow{3}{*}{$\begin{array}{r}07 / 15 / 98 \\
07 / 28 / 98 \\
3\end{array}$} & \multirow{2}{*}{$\begin{array}{l}\text { Material: } \\
\text { Checked by }\end{array}$} & & \multirow{2}{*}{$3, \mathrm{C}$} \\
\hline & & & & & & & 20.5 & \\
\hline \multicolumn{3}{|c|}{ TRIAL } & 1 & & & 4 & 5 & 6 \\
\hline 1 & \multicolumn{2}{|c|}{ Wt.mold + wet soil } & 7280.8 & 74075 & 7410.7 & 7043.6 & 10144.6 & N/A \\
\hline 2 & \multicolumn{2}{|c|}{ Wt. mold } & 28433 & 2843.3 & 2843.3 & 2843.3 & 5633.8 & N/A \\
\hline 3 & \multicolumn{2}{|c|}{ Wt. wet soil } & 4437.5 & 4564.2 & 4567.4 & 4200.3 & 4510.8 & N/A \\
\hline 4 & \multicolumn{2}{|c|}{ Wet Density, PCF } & 130.4 & 134.2 & 134.3 & 123.5 & 132.6 & N/A \\
\hline 5 & \multicolumn{2}{|c|}{ Moisture Tare \# } & $\mathbf{G}$ & 113 & 112 & 111 & 125 & N/A \\
\hline 6 & \multicolumn{2}{|c|}{ Wt wet soil + tare } & 1158.7 & 1171.5 & 1278.6 & 1187.2 & 1295.5 & N/A \\
\hline 7 & \multicolumn{2}{|c|}{ Wt dry soil + tare } & 1088.3 & 1079.4 & 1155.9 & 1133.7 & 1148.2 & N/A \\
\hline 8 & \multicolumn{2}{|c|}{ Wt moisture } & 70.4 & 92.1 & 122.7 & 53.5 & 147.3 & N/A \\
\hline 9 & \multicolumn{2}{|c|}{ Wt tare } & 17.1 & 16.9 & 17.1 & 17.0 & 17.1 & N/A \\
\hline 10 & \multicolumn{2}{|c|}{ Wt dry soil } & 1071.2 & 1062.5 & 1138.8 & 1116.7 & 1131.1 & N/A \\
\hline 11 & \multicolumn{2}{|c|}{ \% Moisture } & 6.6 & 8.7 & 10.8 & 4.8 & 13.0 & N/A \\
\hline 12 & \multicolumn{2}{|c|}{ Dry Density, PCF } & 122.4 & 123.5 & 121.2 & 117.8 & 117.3 & N/A \\
\hline
\end{tabular}

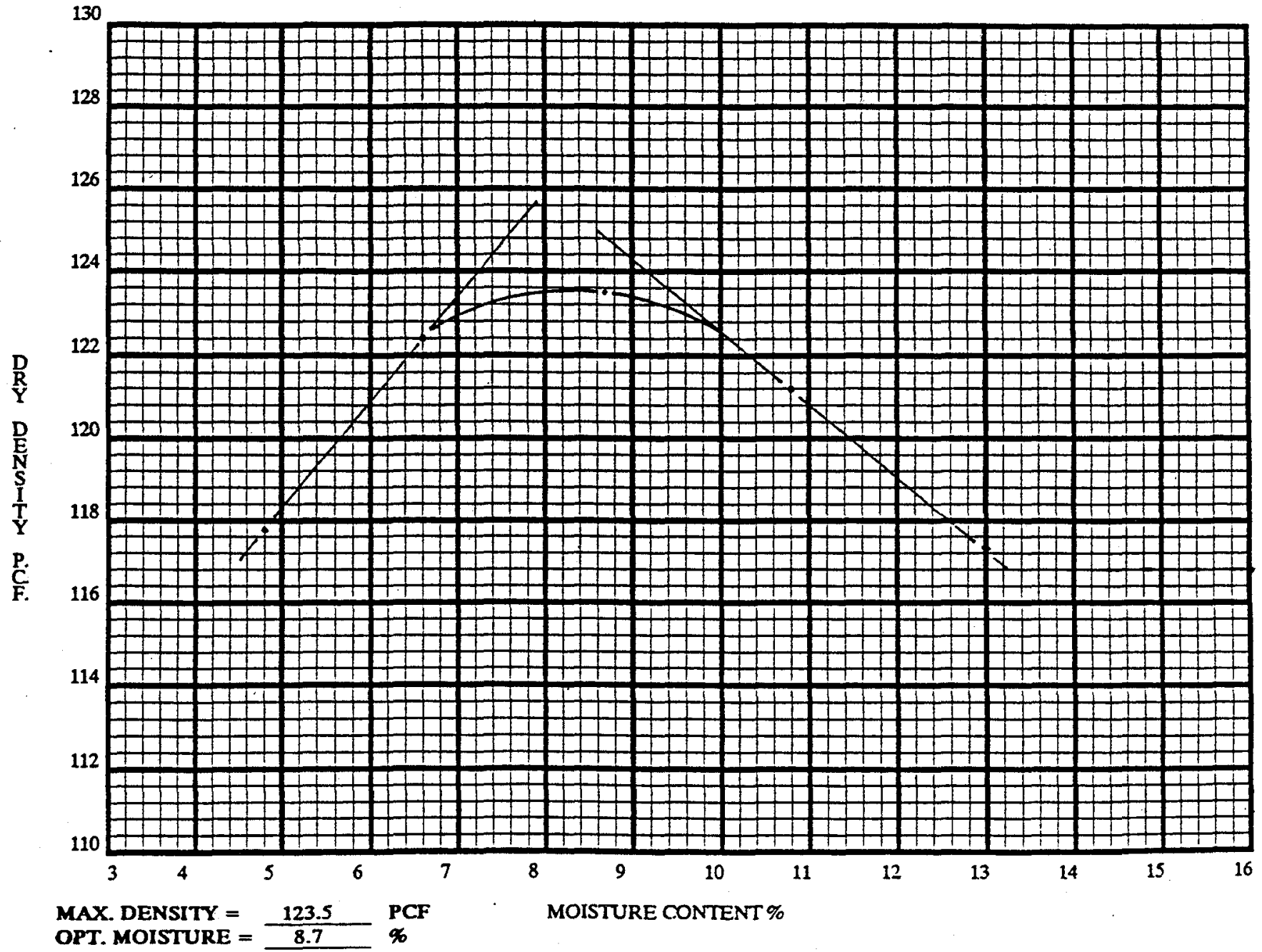

NO SPECIFICATIONS: INFORMATION ONLY

Equipment used: PM 16. PTL W1256. Cal. date: 06/02/98. Cal. due: 06/02/99

CC: D. MADSEN BECHTEL MTL BECHTEL FILES 


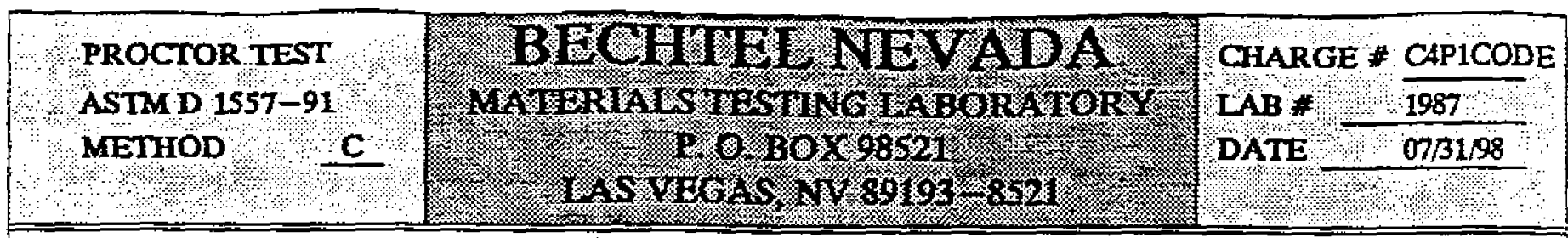

\begin{tabular}{|c|c|c|c|c|c|c|c|c|}
\hline \multirow{3}{*}{\multicolumn{2}{|c|}{$\begin{array}{l}\text { Project: } \\
\text { Sampled by: } \\
\text { Tested by: }\end{array}$}} & \multicolumn{2}{|c|}{ TIR AREA 3 \& 9} & \multicolumn{3}{|c|}{ Requested by: D. MADSEN } & \multirow{2}{*}{$\begin{array}{l}\text { User/Agency: } \\
\text { SANDLA B }\end{array}$} & \multirow{2}{*}{ BECHIEL } \\
\hline & & \multirow{2}{*}{\multicolumn{2}{|c|}{$\begin{array}{l}\text { D. HERRINGTON } \\
\text { T. HIGH }\end{array}$}} & \multirow{2}{*}{$\begin{array}{l}\text { Date sampled: } \\
\text { Date tested: }\end{array}$} & \multirow{2}{*}{$\frac{07 / 28 / 98}{07 / 30 / 98}$} & \multirow{2}{*}{$\begin{array}{l}\text { Material: } \\
\text { Checked b }\end{array}$} & & \\
\hline & & & & & & & by: & k \\
\hline \multicolumn{3}{|c|}{ TRIAL } & 1 & 2 & 3 & 4 & 3 & 6 \\
\hline 1 & \multicolumn{2}{|c|}{ Whanold + ver soil } & 7583.4 & 7485.8 & 73543 & 70193 & $\mathrm{~N} / \mathrm{A}$ & N/A \\
\hline 2 & \multicolumn{2}{|c|}{$W_{L}$ mold } & 2843.3 & 28433 & 2843.3 & 28433 & $\mathrm{~N} / \mathrm{A}$ & N/A \\
\hline 3 & \multicolumn{2}{|c|}{ Wh. wet soil } & 4740.1 & 4642.5 & 4511.0 & 4176.0 & $\mathrm{~N} / \mathrm{A}$ & $\mathrm{N} / \mathrm{A}$ \\
\hline 4 & \multicolumn{2}{|c|}{ Wet Density. PCF } & 1393 & 1365 & 1326 & 122.8 & $\mathrm{~N} / \mathrm{A}$ & N/A \\
\hline 5 & \multicolumn{2}{|c|}{ Moisture Tare * } & 124 & 127 & 128 & 108 & $\mathrm{~N} / \mathrm{A}$ & $\mathrm{N} / \mathrm{A}$ \\
\hline 6 & \multicolumn{2}{|c|}{$\mathrm{W}_{\mathrm{t}}$ wet soil + tare } & 1181.2 & 1332.7 & 1291.8 & 1147.9 & $\mathrm{~N} / \mathrm{A}$ & N/A \\
\hline 7 & \multicolumn{2}{|c|}{ Wh dry soil + tare } & 1076.1 & 1193.4 & 11983 & 1086.4 & N/A & N/A \\
\hline 8 & \multicolumn{2}{|c|}{ Wh moisture } & 105.1 & 139.3 & 935 & 61.5 & N/A & $\mathrm{N} / \mathrm{A}$ \\
\hline 9 & \multicolumn{2}{|c|}{ Wh tare } & 17.1 & 172 & 17.2 & 172 & $\mathrm{~N} / \mathrm{A}$ & $\mathrm{N} / \mathrm{A}$ \\
\hline 10 & \multicolumn{2}{|c|}{ Wt dry soil } & 1059.0 & 1176.2 & 1181.1 & 10692 & N/A & N/A \\
\hline 11 & \multicolumn{2}{|c|}{ \% Moixture } & 9.9 & 11.8 & 7.9 & 5.8 & N/A & N/A \\
\hline 12 & \multicolumn{2}{|c|}{ Dry Density, PCF } & 126.8 & 1220 & 122.9 & 116.1 & $\mathbf{N} / \mathbf{A}$ & N/A \\
\hline
\end{tabular}

131

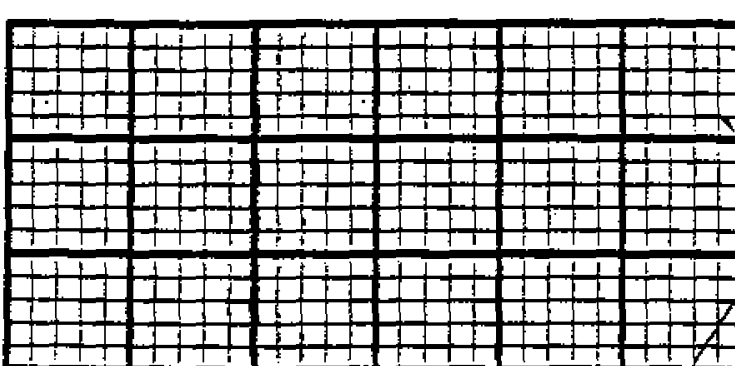

TIR AREA 3 \& 9
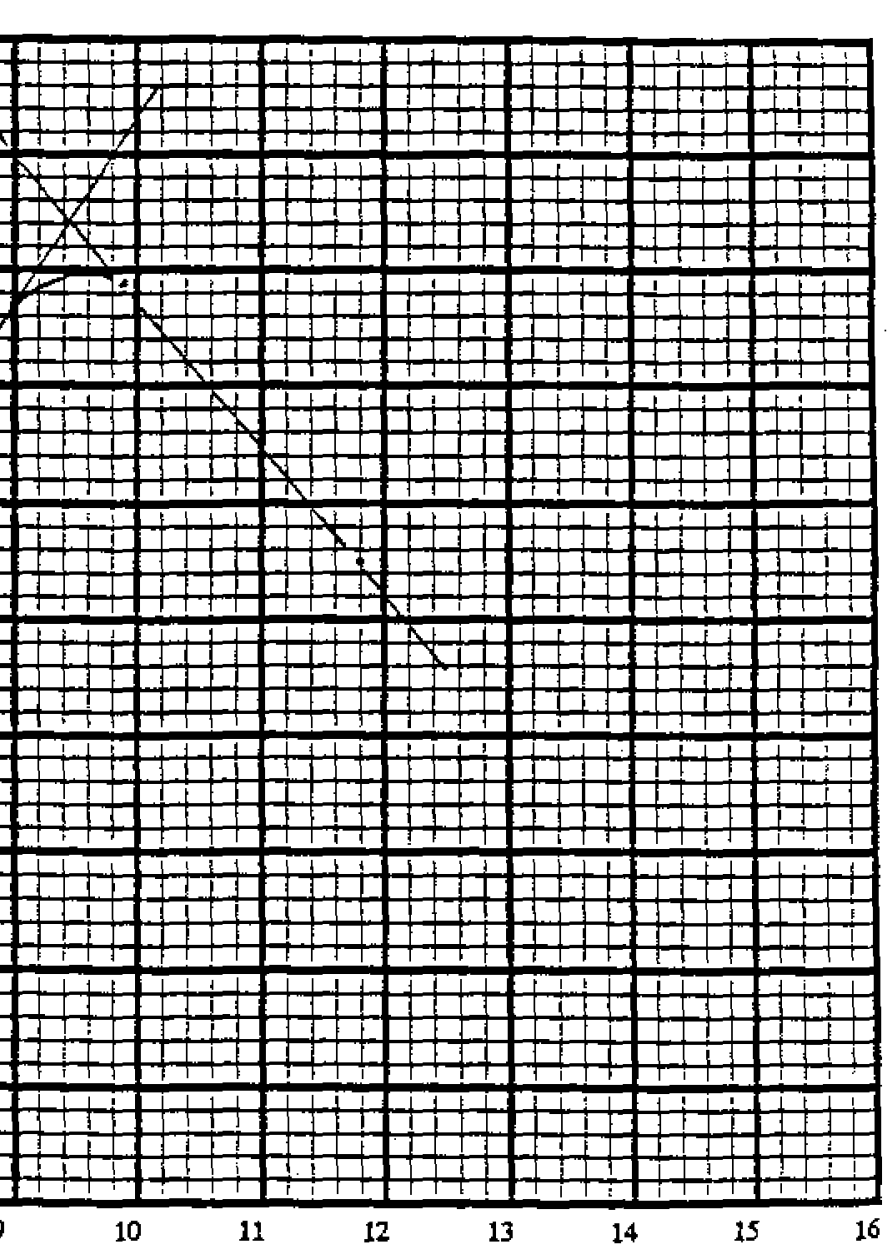

111 L
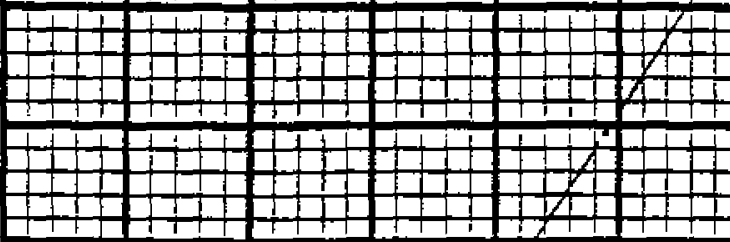

119
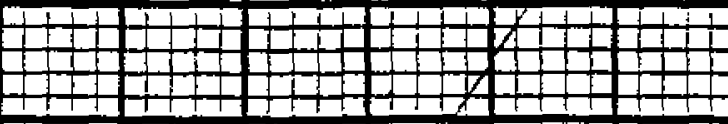

117
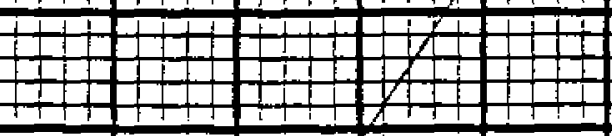

115
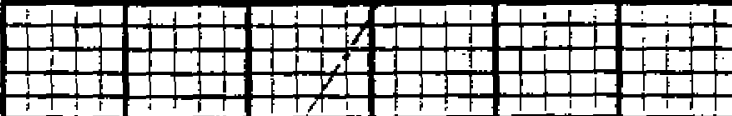

113

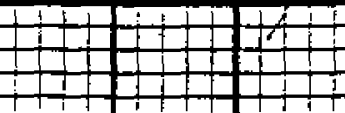

MAX DENSITY $=\quad 127.0$

OPT. MOISTURE $=\frac{-9.5}{2} \%$

MOISTURE CONTENT \%

NO SPECIFCATIONS: INFORMATION ONLY

Equipment used: PM 16. PTL W12\$6. Cal. date:06/02/98. Cal. due:06/0099
CC: D.MADSEN BECHTEL MTL BECITEL FLES 


\section{PROCTORS FOR TTR AREA 3}

DATE: 07/31/98

CHARGE\#. C4P1CODE

LAB \# LOCATION DRY DENSITY MOISTURE

$\begin{array}{rrrrr}1918 & \mathrm{~A} / 3-1 / 1 & 125.5 & 9.6 & \\ 1919 & \mathrm{~A} / 3-1 / 2 & 128.0 & 9.7 & \\ 1920 & \mathrm{~A} / 3-2 / 1 & 128.4 & 8.7 & \\ 1921 & \mathrm{~A} / 3-3 / 3 & 123.0 & 8.9 & \\ 1922 & \mathrm{~A} / 3-3 / 4 & 125.5 & 9.5 & \\ 1923 & \mathrm{~A} / 3-4 / 1 & 127.0 & 8.8 & \\ 1924 & \mathrm{~A} / 3-4 / 2 & 129.5 & 8.4 & \\ 1925 & \mathrm{~A} / 3-5 / 1 & 122.1 & 9.0 & \\ 1926 & \mathrm{~A} / 3-6 / 1 & 125.0 & 10.1 & \\ 1927 & \mathrm{~A} / 3-6 / 2 & 124.0 & 9.0 & \\ 1928 & \mathrm{~A} / 3-8 / 1 & 129.5 & 8.3 & \\ 1929 & \mathrm{~A} / 3-8 / 2 & 123.5 & 8.7 & \\ 1987 & \text { SANDIA BORROW } & 123.0 & 10.4 & \text { OLD } \\ & & 127.0 & 9.5 & \text { NEW }\end{array}$

COMPILED FROM OTHER REPORTS. NO EQUIPMENT USED. 
IAS UECASS, UV $891980-8521$

Request / Test Report.

Requested by:

User/Agency:

D. MADSEN

Project:

BECHTEL

TTR AREA 3

Sampled by:

D. HERRINGTON

Tested By:

Checked by:

T. HIGH \& D. JOHNSON

D. HERRINGTON LL $2 /$.

$\log \#$ $\$$ N/A

Charge \# +1 C4P1CODE

MTL Lab \#, 1918

Material: NATIVE A3-1/1

Material: $\quad$ NATIVE
Date Sampled: $07 / 15 / 98$

Date tested: $07 / 22 / 98$

Date checked: $10-1-98$

\begin{tabular}{|c|c|c|c|c|c|}
\hline LABORATORY TEST REQUIRED & & & VE ANALYSIS & & \\
\hline $\begin{array}{l}\text { Sieve Analysis } \\
\text { ASTM C-136- }\end{array}$ & $\begin{array}{l}\text { U.S. Standard } \\
\text { Sieve \# }\end{array}$ & $\begin{array}{l}\text { Cumulative } \\
\text { Wt Retained }\end{array}$ & \% Retained & \% Passing & $\begin{array}{l}\text { Spec \% } \\
\text { Passing }\end{array}$ \\
\hline $\begin{array}{ll}X & \text { (ASTM C-117-89) } \\
X & \text { (ASTM D-422-90) }\end{array}$ & 3 & 0.0 & $0 \%$ & $100 \%$ & N/A \\
\hline $\begin{array}{l}\text { (ASTM D-1140-82) } \\
\text { Moisture Content }\end{array}$ & $11 / 2^{n}$ & 0.0 & $0 \%$ & $100 \%$ & N/A \\
\hline 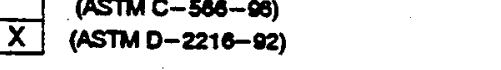 & $3 / 4^{*}$ & 0.0 & $0 \%$ & $100 \%$ & N/A \\
\hline Unit Weight & $3 / 8^{m}$ & 31.1 & $2 \%$ & $98 \%$ & $N / A$ \\
\hline $\log$ & 4 & 146.5 & $11 \%$ & $89 \%$ & N/A \\
\hline $\begin{array}{l}\text { Soil Classification } \\
\text { Percent Porosity }\end{array}$ & 10 & 261.6 & $19 \%$ & $81 \%$ & N/A \\
\hline Specific Gravity & 40 & 470.9 & $34 \%$ & $66 \%$ & N/A \\
\hline $\begin{array}{l}\text { (ASTM C-127-88/128-93) } \\
\text { (ASTM D-584-92) }\end{array}$ & 100 & 680.4 & $50 \%$ & $50 \%$ & N/A \\
\hline Other (as noted) & 200 & 853.9 & $62.5 \%$ & $37.5 \%$ & $N / A$ \\
\hline Soil Class: & Sample Wt (g) & DRY $=$ & 1366.3 & WET $=$ & $N / A$ \\
\hline
\end{tabular}

\begin{tabular}{|c|c|c|c|}
\hline \multirow{4}{*}{$\begin{array}{l}\text { Wet Weight + Tare } \\
\text { Dry Weight + Tare }\end{array}$} & \multicolumn{3}{|c|}{ MOISTURE CONTENT } \\
\hline & PAN \# 30 & N/A & N/A \\
\hline & 2345.7 & N/A & N/A \\
\hline & 2262.3 & N/A & $N / A$ \\
\hline Water & 83.4 & N/A & N/A \\
\hline Tare & 896.0 & N/A & N/A \\
\hline Dry Weight & 1366.3 & N/A & $N / A$ \\
\hline Moisture $\%$ & $6.1 \%$ & N/A & N/A \\
\hline
\end{tabular}

Oversize Specific Gravity:

N/A

Container Size(ft ^ 3 )
Total Weight (b)
Tare Weight (lb)
Material Weight (b)
Unit Weight (P.C.F.)
Percent Porosity

UNIT WEIGHT

EQUIPMENT USED: PM 16, PTL \#1256, Calibration Date: 06/02/98

Sieve $11 / 2^{n}$

PTL \# Y303222 Cal. Date: 03/27/98 Cal. Due: 03/27/99

Sieve 3/4"

PTL \# Y303276 Cal. Date: 03/27/98 Cal. Due: 03/27/99

Specific Gravity:

Calibration Due: 06/02/99

Sieve 3/8

PTL \# Y302106 Cal. Date: 03/27/98 Cal. Due: 03/27/99

Sieve \# 4

PTL \# Y302043 Cal. Date: 03/26/98 Cal. Due: 03/26/99

Sieve \# 10

PTL\# Y11621 Cal. Date: 10/08/97 Cal. Due: 10/08/99

Sieve \# 16

PTL \# Y302079 Cal. Date: 03/25/98 Cal. Due: 03/26/99

Sieve \# 40

PTL \# Y106 Cal. Date: 10/09/97 Cal. Due: 10/09/99

Sieve \# 100

PTL \# Y10035 Cal. Date: 05/21/98 Cal. Due: 05/21/99

Sieve \# 200

PTL \# Y11599 Cal. Date: 10/09/97 Cal. Due: 10/09/99

\begin{tabular}{|c|c|}
\hline \multicolumn{2}{|c|}{ Loose } \\
\hline N/A & Nodded \\
\hline N/A & N/A \\
\hline N/A & N/A \\
\hline N/A & N/A \\
\hline N/A & N/A \\
\hline N/A & N/A \\
\hline
\end{tabular}

N/A

REMARKS: NONE 


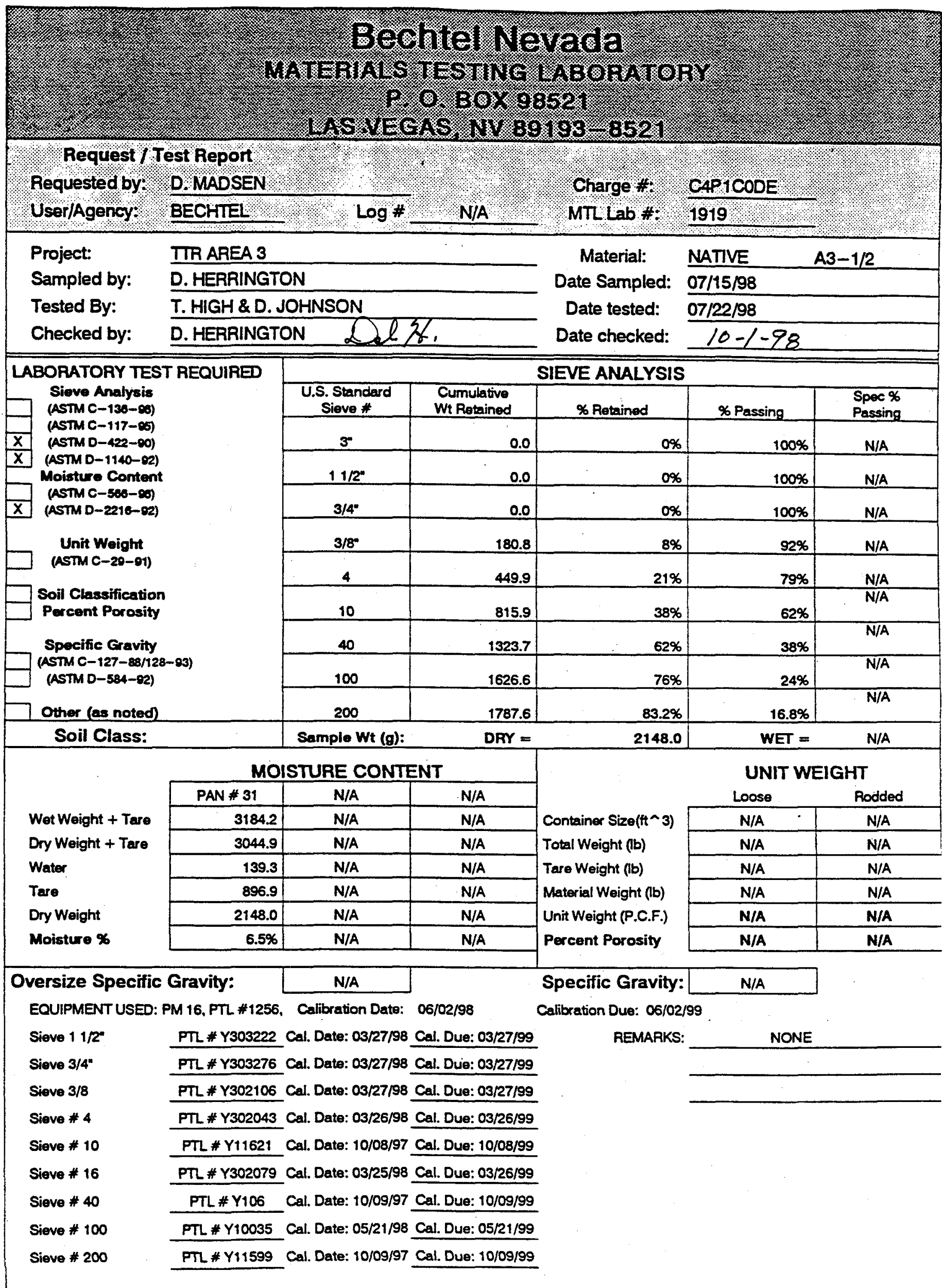




\section{Bechtel Nevada

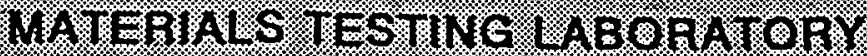 \\ P. . $0.8 .0 \% 98524$ \\ 1 AS. VEGAS. UV $89.193-8521$}

\section{Request / Test Report}

Requested by: D. MADSEN

User/Agency: , BECHTEL

Project:

TIR AREA 3

Sampled by:

D. HERRINGTON

Tested By:

T. HIGH \& D. JOHNSON

Checked by: $\log \# \quad$ N/A
Charge \#: 1 C4P1CODE

MTL Lab \#: 1920

Material: NATIVE

$A 3-2 / 1$

D. HERRINGTON Dal\%.

Date Sampled: $07 / 15 / 98$

Date tested: $\quad 07 / 22 / 98$

Date checked: $10-1-98$

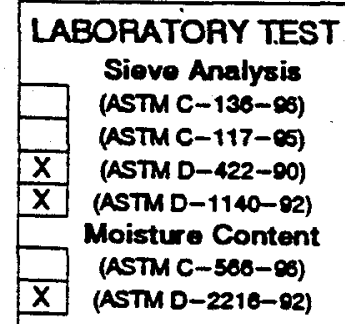

Unit Weight

(ASTM C-20-91)

Soil Classification

Percent Porosity

Specific Gravity

(ASTM C-127-88/128-93)

(ASTM D-584-02)

Other (as noted)

Soil Class:

\section{REQUIRED}

\section{MOISTURE CONTENT}

Wet Weight + Tare

Dry Weight + Tare

Water

Tare

Dry Weight

Moisture \%

\begin{tabular}{|r|c|c|}
\hline PAN \# 32 & N/A & N/A \\
\hline 2551.8 & N/A & N/A \\
\hline 865.6 & N/A & N/A \\
\hline 85.2 & N/A & N/A \\
\hline 894.5 & N/A & N/A \\
\hline 1571.1 & N/A & N/A \\
\hline $5.5 \%$ & N/A & N/A \\
\hline
\end{tabular}

Oversize Specific Gravity:

EQUIPMENT USED: PM 16, PTL \#1256, Calibration Date: 06/02/98

Sieve 1 1/2"

Sieve 3/4"

Sieve $3 / 8$

Sieve \# 4

Sieve \# 10

Sieve \# 16

Sieve \# 40

Sieve \# 100

Siove \# 200
PTL \# Y303222 Cal. Date: 03/27/98 Cal. Due: 03/27/99 PTL \# Y303276 Cal. Date: 03/27/98 Cal. Due: 03/27/99 PTL \# Y302106 Cal. Date: 03/27/98 Cal. Due: 03/27/99 PTL \# Y302043 Cal. Date: 03/26/98 Cal. Due: 03/26/99 PTL \# Y11621 Cal. Date: 10/08/97 Cal. Due: 10/08/99 PTL \# Y302079 Cal. Date: 03/25/98 Cal. Due: 03/26/99 PTL \# Y106 Cal. Date: 10/09/97 Cal. Due: 10/09/99 PTL \# Y10035 Cal. Date: 05/21/98 Cal. Due: 05/21/99 PTL \# Y11599 Cal. Date: 10/09/97 Cal. Due: 10/09/99

\section{SIEVE ANALYSIS}

\begin{tabular}{r|r|r|}
\hline & \% Passing & $\begin{array}{r}\text { Spec \% } \\
\text { Pessing }\end{array}$ \\
\hline $0 \%$ & $100 \%$ & N/A \\
\hline $0 \%$ & $100 \%$ & N/A \\
\hline $0 \%$ & $100 \%$ & N/A \\
\hline $3 \%$ & $97 \%$ & N/A \\
\hline $10 \%$ & $90 \%$ & N/A \\
\hline $20 \%$ & $80 \%$ & N/A \\
\hline $42 \%$ & $58 \%$ & N/A \\
\hline $63 \%$ & $37 \%$ & N/A \\
\hline $77.7 \%$ & $22.3 \%$ & N/A \\
\hline 1571.1 & WET $=$ & N/A \\
\hline
\end{tabular}

Container Size(tt^ 3$)$

Total Weight (lb).

Tare Weight (b)

Material Weight (b)

Unit Weight (P.C.F.)

Percent Porosity

UNIT WEIGHT

Specific Gravity:

Loose Rodded

\begin{tabular}{|c|c|}
\hline Loose & Rodded \\
\hline N/A & N/A \\
\hline N/A & N/A \\
\hline N/A & N/A \\
\hline N/A & N/A \\
\hline N/A & N/A \\
\hline N/A & N/A \\
\hline
\end{tabular}

Calibration Due: 06/02/99

N/A

REMARKS: NONE 


\begin{tabular}{|c|c|c|c|c|c|c|}
\hline 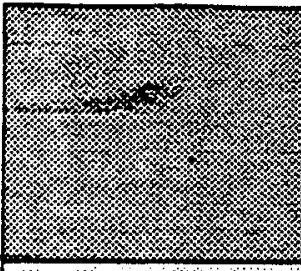 & - & 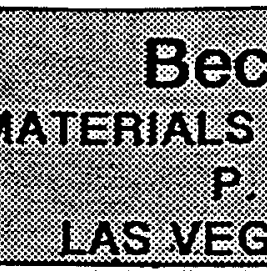 & 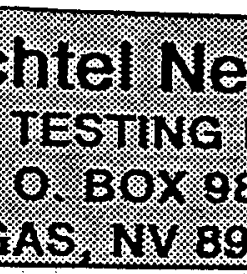 & 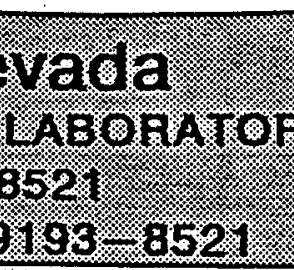 & $\frac{6}{6}$ & \\
\hline Request / & est Report & & & & & \\
\hline Requested by: & D. MADSEN & ?. & & Charge \#: & CAP 1CODE & \\
\hline User/Agency: & BECHIEL & Log \# & N/A & MTL Lab \#: & 1921 & \\
\hline Project: & TIR AREA 3 & & & Material: & NATIVE & $A 3-3 / 3$ \\
\hline Sampled by: & D. HERRINGT & ON & & Date Sampled: & $07 / 15 / 98$ & \\
\hline Tested By: & T. HIGH \& D.J & JOHNSON & & Date tested: & $07 / 22 / 98$ & \\
\hline Checked by: & D. HERRINGT & ON Dah 2 & & Date checked: & $10-1-98$ & \\
\hline LABORATORY TES & TREQUIRED & & & SIEVE ANALYSIS & & \\
\hline $\begin{array}{r}\text { Sieve Analysis } \\
\text { (ASTM C-136-(8) }\end{array}$ & & $\begin{array}{c}\text { U.S. Standard } \\
\text { Sieve \# }\end{array}$ & $\begin{array}{l}\text { Cumulative } \\
\text { Wt Retained }\end{array}$ & \% Retained & $\%$ Passing & $\begin{array}{l}\text { Spec \% } \\
\text { Passing }\end{array}$ \\
\hline \begin{tabular}{|l} 
\\
$X$ \\
\end{tabular} & & 3 & 0.0 & $0 \%$ & $100 \%$ & N/A \\
\hline \begin{tabular}{|c|}
$X$ \\
(ASTM D-1140-92) \\
Moisturo Conten
\end{tabular} & & $11 / 2^{n}$ & 0.0 & $0 \%$ & $100 \%$ & N/A \\
\hline 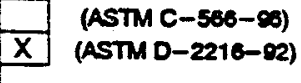 & & $3 / 4^{*}$ & 0.0 & $0 \%$ & $100 \%$ & N/A \\
\hline Unit Woight & & $3 / 8^{n}$ & 20.7 & $1 \%$ & $99 \%$ & N/A \\
\hline $\begin{array}{l}\square \\
\end{array}$ & & 4 & 89.1 & $5 \%$ & $95 \%$ & N/A \\
\hline $\begin{array}{l}\text { Soil Classificatior } \\
\text { Percent Porosity }\end{array}$ & & 10 & 211.9 & $12 \%$ & $88 \%$ & $N / A$ \\
\hline Specific Gravity & & 40 & 522.9 & $29 \%$ & $71 \%$ & N/A \\
\hline $\begin{array}{l}\text { (ASTM C-127-83/12 } \\
\text { (ASTM D-584-92) }\end{array}$ & & 100 & 1042.3 & $59 \%$ & $41 \%$ & N/A \\
\hline Other (es noted) & & 200 & 1333.9 & $74.9 \%$ & $25.1 \%$ & N/A \\
\hline Soil Class: & & Sample Wt (g): & DRY $=$ & 1781.2 & WET $=$ & N/A \\
\hline & $\mathrm{MO}$ & ISTURE CONTE & NT & & UNIT W & EIGHT \\
\hline & PAN 33 & N/A & N/A & & Loose & Rodded \\
\hline Wet Weight + Tare & 2851.7 & N/A & N/A & Container Size $\left(\mathbb{t}^{\wedge} 3\right)$ & N/A & $\mathrm{N} / \mathrm{A}$ \\
\hline Dry Weight + Tare & 2721.1 & N/A & N/A & Total Weight ollo & $\mathrm{N} / \mathrm{A}$ & N/A \\
\hline Water & 140.5 & N/A & N/A & Tare Weight (lb) & N/A & N/A \\
\hline Tare & 939.9 & N/A & N/A & Material Weight (b) & N/A & N/A \\
\hline Dry Weight & 1781.2 & N/A & N/A & Unit Weight (P.C.F.) & N/A & N/A \\
\hline Moisture \% & $7.9 \%$ & N/A & N/A & Percent Porosity & N/A & N/A \\
\hline Oversize Specific & Gravity: & N/A & & Specific Gravity: & N/A & \\
\hline EOUIPMENT USED: & PM 16, PTL \#1256, & Calibration Date: & $06 / 02 / 98$ & Calibration Due: $06 / 02 /$ & & \\
\hline Sieve $11 / 2^{n}$ & PTL \# Y303222 & Cal. Date: $03 / 27 / 98$ & Cal. Due: 03/27/99 & REMARKS: & NONE & \\
\hline Sieve 3/4" & PTL \# Y303276 & Cal. Date: $03 / 27 / 98$ & Cal. Due: 03/27/99 & & & \\
\hline Sieve $3 / 8$ & PTL \# Y302106 & Cell. Date: 03/27/98 & Cal. Due: 03/27/99 & & & \\
\hline Sieve \# 4 & PTL\# Y302043 & Cal. Date: $03 / 26 / 98$ & Cal. Due: 03/26/99 & & & \\
\hline Sieve \# 10 & PTL \# Y11621 & Cal. Date: 10/08/97 & Cal. Due: 10/08/99 & & & \\
\hline Sieve \# 16 & PTL \# Y302079 & Cal. Dete: $03 / 25 / 98$ & Cal. Due: 03/26/99 & & & \\
\hline Sieve \# 40 & PTL \# Y106 & Cal. Date: 10/09/97 & Cal. Due: $10 / 09 / 99$ & & & \\
\hline Sieve \# 100 & PTL \# Y10035 & Cal. Date: 05/21/98 & Cal. Due: 05/21/99 & & & \\
\hline Sieve \# 200 & PTL \# Y11599 & Cal. Date: 10/09/97 & Cal. Due: 10/09/99 & & & \\
\hline
\end{tabular}




\section{Bechtel Nevada

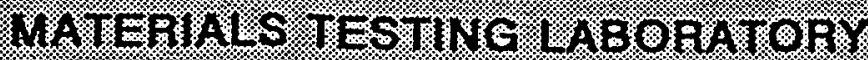 \\ P . (8. BOR 9852 :

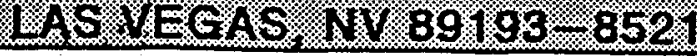

Request / Test Report

Requested by: : D. MADSEN

User/Agency: BECHTEL

$\log \# \quad$ N/A

Charge \#: CAP 1CODE

Project: IIR AREA 3

Sampled by: D. HERRINGTON

Tested By:

T. HIGH \& D. JOHNSON

Checked by:

D. HERRINGTON DalK.

MTL Lab \#: 1922

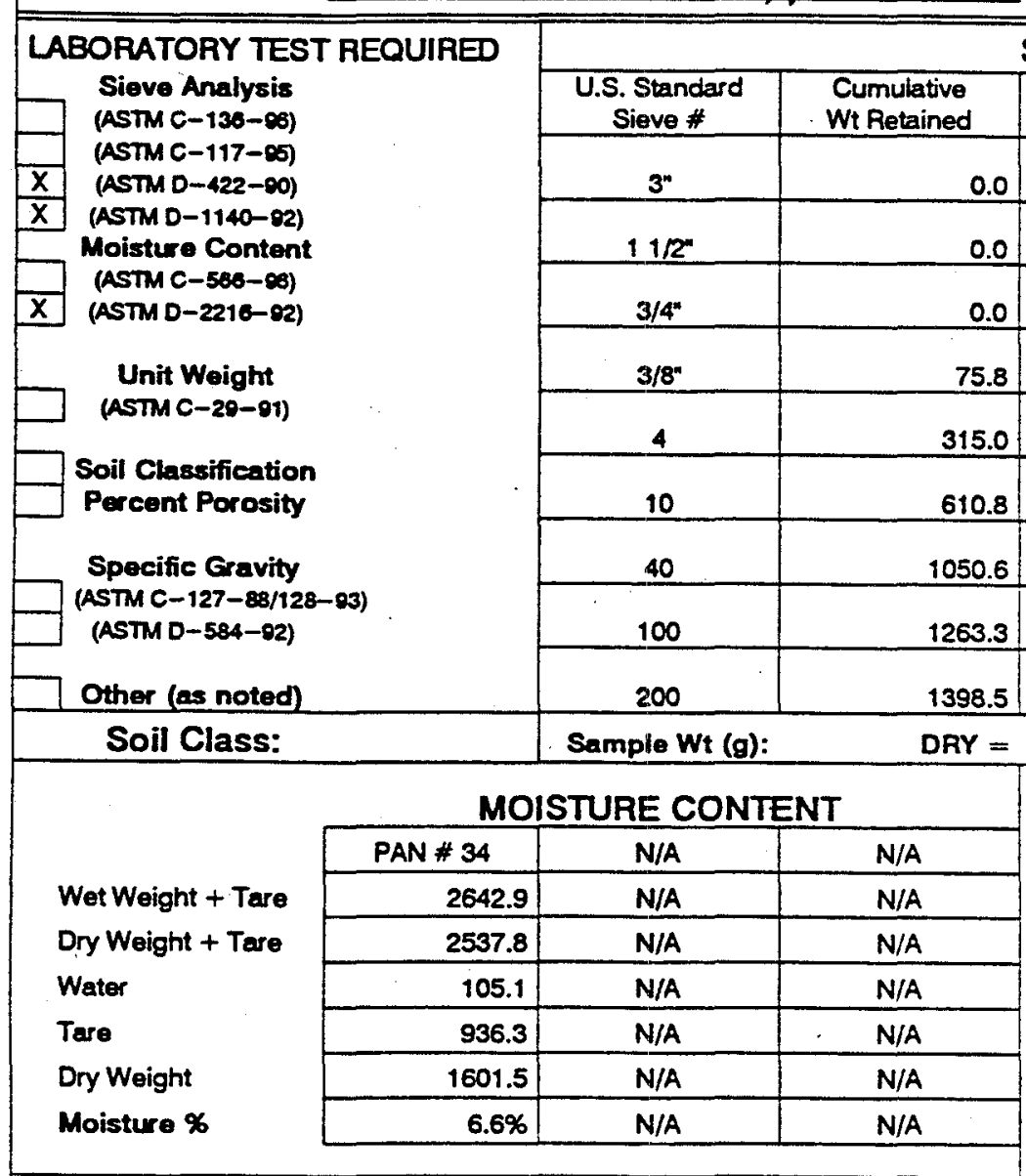

\section{Oversize Specific Gravity:}

N/A

EQUIPMENT USED: PM 16, PTL \#1256, Calibration Date: 06/02/98
Sieve $11 / 2^{\prime \prime}$
PTL \# Y303222 Cal. Date: 03/27/98 Cal. Due: 03/27/99
Sieve 3/4"
PTL \# Y303276 Cal. Date: 03/27/98 Cal. Due: 03/27/99
Sieve $3 / 8$
PTL \# Y302106 Cal. Date: 03/27/98 Cal. Due: 03/27/99
Sieve \# 4
PTL \# Y302043 Cal. Date: 03/26/98 Cal. Due: 03/26/99
Sieve \# 10
PTL \# Y11621 Cal. Date: 10/08/97 Cal. Due: 10/08/99
Sieve \# 16
PTL \# Y302079 Cal. Date: 03/25/98 Cal. Due: 03/26/99
Sieve \# 40
PTL \# Y106 Cal. Date: 10/09/97 Cal. Due: 10/09/99
Sieve \# 100
PTL \# Y10035 Cal. Date: 05/21/98 Cal. Due: 05/21/99
Siove \# 200
PTL \# Y11599 Cal. Date: 10/09/97 Cal. Due: 10/09/99

Material: NATIVE

A3-3/4

Date Sampled: $07 / 15 / 98$

Date tested: $\quad 07 / 22 / 98$

Date checked: $\quad 10-1-98$

\section{SIEVE ANALYSIS}

Container Size( $\left(t^{\wedge}\right.$ 3)

Total Weight (lb)

Tare Weight (lb)

Material Weight (lb)

Unit Weight (P.C.F.)

Percent Porosity

Specific Gravity:

Calibration Due: 06/02/99

REMARKS

NONE 


\begin{tabular}{|c|c|c|c|c|c|c|}
\hline 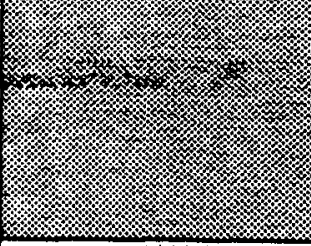 & 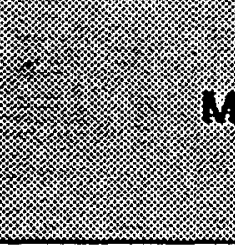 & 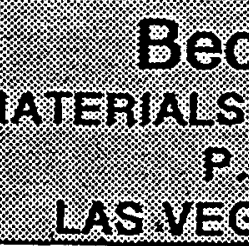 & 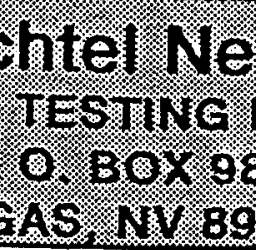 & 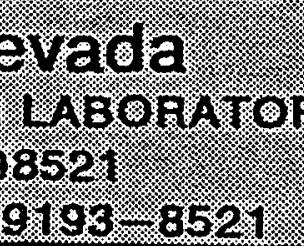 & 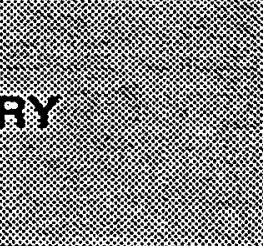 & \\
\hline Request T T & est Report & & & & & \\
\hline Requested by: & D. MADSEN & & & Charge \#: & CAPICODE & \\
\hline User/Agency: & BECHTEL & $\log \#$ & N/A & MTL Lab \#: & 1923 & \\
\hline Project: & TIR AREA 3 & & & Material: & NATIVE & A3- $4 / 1$ \\
\hline Sampled by: & D. HERRINGT & ON & & Date Sampled: & $07 / 15 / 98$ & \\
\hline Tested By: & T. HIGH \& D. & JOHNSON & & Date tested: & $07 / 23 / 98$ & \\
\hline Checked by: & D. HERRINGT & Dl & & Date checked: & $10-1.98$ & \\
\hline LABORATORY TES & T REQUIRED & & & SIEVE ANALYSIS & & \\
\hline \begin{tabular}{|l} 
Sieve Analysis \\
(ASTM C-136--6)
\end{tabular} & & $\begin{array}{l}\text { U.S. Standard } \\
\text { Sieve \# }\end{array}$ & $\begin{array}{l}\text { Cumulative } \\
\text { Wt Retained }\end{array}$ & \% Retained & $\%$ Passing & $\begin{array}{l}\text { Spec \% } \\
\text { Passing }\end{array}$ \\
\hline $\begin{array}{ll}X \\
y \\
y\end{array}$ & & $3^{n}$ & 0.0 & $0 \%$ & $100 \%$ & N/A \\
\hline $\begin{array}{l}\text { X (ASTM D-1140-92) } \\
\text { Moisture Content }\end{array}$ & & $11 / 2^{*}$ & 0.0 & $0 \%$ & $100 \%$ & N/A \\
\hline$x$ (ASTM D-2210-92) & & $3 / 4^{\circ}$ & 0.0 & $0 \%$ & $100 \%$ & N/A \\
\hline Unit Woight & & $3 / 8^{*}$ & 114.3 & $6 \%$ & $94 \%$ & N/A \\
\hline (ASTM C-20-91) & $:$ & 4 & 328.7 & $18 \%$ & $82 \%$ & N/A \\
\hline $\begin{array}{l}\text { Soil Classification } \\
\text { Percent Porosity }\end{array}$ & & 10 & 593.9 & $33 \%$ & $67 \%$ & $\frac{N / A}{N / A}$ \\
\hline Specific Gravity & & 40 & 1100.5 & $62 \%$ & $38 \%$ & N/A \\
\hline $\begin{array}{l}\text { (ASTM C- 127-88/128 } \\
\text { (ASTM D-584-82) }\end{array}$ & & 100 & 1324.9 & $74 \%$ & $26 \%$ & N/A \\
\hline Other (as noted) & & 200 & 1475.8 & $82.7 \%$ & $17.3 \%$ & $N / A$ \\
\hline Soil Class: & & Sample Wi (g): & DRY $=$ & 1785.0 & WET $=$ & N/A \\
\hline & MOI & ISTURE CONTE & ENT & & UNIT WE & EIGHT \\
\hline & PAN \# 35 & N/A & N/A & & Loose & Rodded \\
\hline Wet Weight + Tare & 2814.3 & N/A & N/A & Container Size $\left(\mathrm{ft}^{\wedge} 3\right)$ & N/A & N/A \\
\hline Dry Weight + Tare & 2682.0 & N/A & N/A & Total Weight (lb) & $N / A$ & N/A \\
\hline Water & 132.3 & N/A & N/A & Tare Weight (lb) & N/A & N/A \\
\hline Tare & 897.0 & N/A & N/A & Material Weight (b) & N/A & N/A \\
\hline Dry Weight & 1785.0 & N/A & N/A. & Unit Weight (P.C.F.) & $N / A$ & N/A \\
\hline Moisture $\%$ & $7.4 \%$ & N/A & N/A & Percent Porosity & N/A & N/A \\
\hline Oversize Specific & Gravity: & N/A & & Specific Gravity: & N/A & \\
\hline EQUIPMENT USED: & PM 16, PTL \#1256, & Calibration Date: & $06 / 02 / 98$ & Calibration Due: $06 / 02 / 5$ & & \\
\hline Sieve $11 / 2^{\prime \prime}$ & PTL \# Y303222 & Cal. Date: 03/27/98 & Cal. Due: 03/27/99 & REMARKS: & NONE & \\
\hline Sieve 3/4" & PTL \# Y303276 & Cal. Date: $03 / 27 / 98$ & Cal. Due: $03 / 27 / 99$ & & & \\
\hline Sieve $3 / 8$ & PTL \# Y302106 & Cal. Date: 03/27/98 & Cal. Due: $03 / 27 / 99$ & & . & \\
\hline Sieve \#4 & PTL\# Y302043 & Cal. Date: $03 / 26 / 98$ & Cal. Due: $03 / 26 / 99$ & & & \\
\hline Sieve \# 10 & $P T L \# Y 11621$ & Cal. Date: $10 / 08 / 97$. & Cal. Due: $10 / 08 / 99$ & & & \\
\hline Sieve \# 16 & PTL\# Y302079 & Cal. Date: 03/25/98 & Cal. Due: 03/26/99 & & & \\
\hline Sieve \# 40 & PTL \# Y106 & Cal. Date: 10/09/97. & Cal. Due: 10/09/99 & & & \\
\hline Sieve \# 100 & PTL\# Y10035 & Cal. Date: 05/21/98 & Cal. Due: 05/21/99 & & & \\
\hline Sieve \# 200 & PTL\# Y11599 & Cal. Date: $10 / 09 / 97$ & Cal. Due: $10 / 09 / 99$ & & & \\
\hline
\end{tabular}




\begin{tabular}{|c|c|c|c|c|c|c|}
\hline 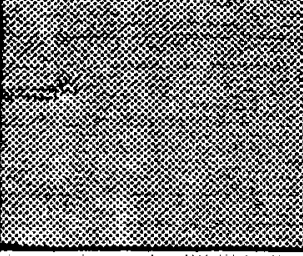 & 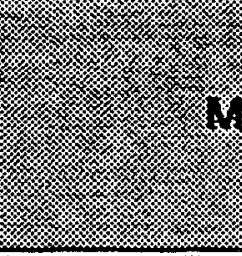 & 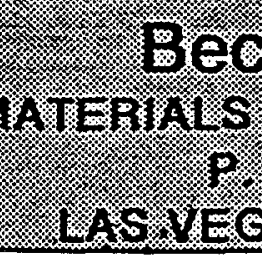 & 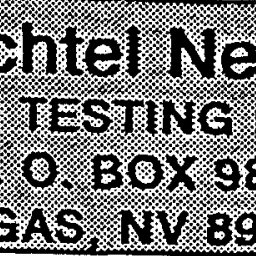 & 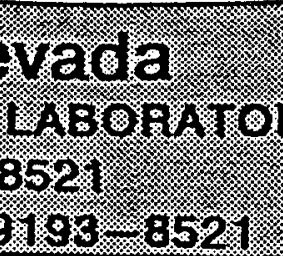 & & \\
\hline Request/T & est Report & & & & & \\
\hline Requested by: & D.MADSEN & & & Charge \#: & CAP 1CODE & \\
\hline User/Agency: & BECHTEL & $\log \#$ & N/A & MTL Lab \#: & 1925 & \\
\hline Project: & TIR AREA 3 & & & Material: & NATIVE & $A 3-5 / 1$ \\
\hline Sampled by: & D. HERRINGT & & & Date Sampled: & $07 / 15 / 98$ & \\
\hline Tested By: & T. HIGH \& D. J & JOHNSON & & Date tested: & $07 / 23 / 98$ & \\
\hline Checked by: & D. HERRINGTC & Sil: & & Date checked: & $10-1-98$ & \\
\hline LABORATORY TES & T REQUIRED & & & SIEVE ANALYSIS & & \\
\hline $\begin{array}{l}\text { Sieve Analysis } \\
\text { (ASTM C-136-(6) }\end{array}$ & & $\begin{array}{l}\text { U.S. Standard } \\
\text { Sieve \# }\end{array}$ & $\begin{array}{l}\text { Cumulative } \\
\text { Wt Retained }\end{array}$ & \% Retained & \% Passing & $\begin{array}{l}\text { Spec } \% \\
\text { Passing }\end{array}$ \\
\hline 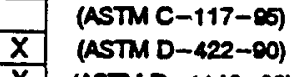 & & 3 & 0.0 & $0 \%$ & $100 \%$ & N/A \\
\hline $\begin{array}{l}\text { X (ASTM D-1140-92) } \\
\text { Moisture Content }\end{array}$ & . & $11 / 2^{n}$ & 0.0 & $0 \%$ & $100 \%$ & N/A \\
\hline 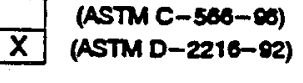 & & $3 / 4^{*}$ & 0.0 & $0 \%$ & $100 \%$ & N/A \\
\hline Unit Weight & & $3 / 8^{\prime \prime}$ & 12.2 & $1 \%$ & $99 \%$ & N/A \\
\hline (ASTM C-20-91) & & 4 & 81.1 & $4 \%$ & $96 \%$ & N/A \\
\hline $\begin{array}{l}\text { Soil Classification } \\
\text { Percent Porosity }\end{array}$ & & 10 & 240.7 & $13 \%$ & $87 \%$ & N/A \\
\hline Spocific Gravity & & 40 & 558.4 & $31 \%$ & $69 \%$ & N/A \\
\hline $\begin{array}{l}\text { IASTM C-127-83/128 } \\
\text { (ASTM D-584-02) }\end{array}$ & & 100 & 993.0 & $54 \%$ & $46 \%$ & N/A \\
\hline Other (as noted) & & 200 & 1281.6 & $70.1 \%$ & $29.9 \%$ & N/A \\
\hline Soil Class: & & Semple Wt (g): & DAY $=$ & 1827.9 & WET $=$ & N/A \\
\hline & $\mathrm{MOI}$ & ISTURE CONTE & ENT & & UNIT W & EIGHT \\
\hline & PAN $\# 37$ & N/A & N/A & & Loose & Rodded \\
\hline Wet Weight + Tare & 2939.2 & N/A & N/A & Container Size $(t+\sim 3)$ & N/A & N/A \\
\hline Dry Woight + Tare & 2809.2 & N/A & N/A & Total Weight (lb) & $N / A$ & N/A \\
\hline Water & 130.0 & $N / A$ & N/A & Taro Weight (b) & N/A & N/A \\
\hline Tare & 981.3 & N/A & N/A & Material Weight (b) & $N / A$ & $N / A$ \\
\hline Dry Weight & 1827.9 & N/A & N/A & Unit Woight (P.C.F.) & N/A & N/A \\
\hline Moisture \% & $7.1 \%$ & $\mathrm{~N} / \mathrm{A}$ & N/A & Percent Porosity & N/A & N/A \\
\hline Oversize Specific & Gravity: & N/A & & Specific Gravity: & N/A & \\
\hline EQUIPMENT USED: & PM 16, PTL \#1256, & - Calibration Date: & $06 / 02 / 98$ & Calibration Due: $06 / 02$ & & \\
\hline Sieve $11 / 2^{n}$ & PTL \# Y303222 & Cal. Date: 03/27/98 & Cal. Due: 03/27/99 & REMARKS: & NONE & \\
\hline Sieve 3/4" & PTL \# Y303276 & Cal. Date: $03 / 27 / 98$ & Cal. Dup: 03/27/99 & & & \\
\hline Sieve 3/8 & PTL \# Y302106 & Cal. Date: $03 / 27 / 98$ & Cal. Due: 03/27/99 & & & \\
\hline Sieve \# 4 & $P T L \# Y_{302043}$ & Cal. Date: $03 / 26 / 98$ & Cal. Due: 03/26/99 & & & \\
\hline Sieve \# 10 & PTL\# Y11621 & Cal. Date: $10 / 08 / 97$ & Cal. Due: $10 / 08 / 99$ & & & \\
\hline Sieve \# 16 & PTL \# Y302079 & Cal. Date: $03 / 25 / 98$ & Cal. Due: 03/26/99 & & & \\
\hline Sieve \# 40 & PTL \# Y106 & Cal. Date: 10/09/97 & Cal. Due: 10/09/99 & & & \\
\hline Sieve \# 100 & PTL \# Y10035 & Cal. Date: 05/21/98 & Cal. Due: 05/21/99 & & & \\
\hline Sieve \# 200 & PTL\# Y11599 & Cal. Date: $10 / 09 / 97$ & Cal. Due: $10 / 09 / 99$ & & & \\
\hline
\end{tabular}




\section{Bechtel Nevada

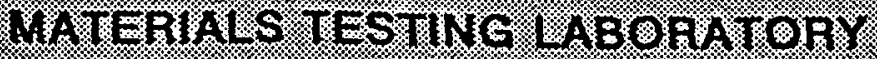 \\ ?. $0 . \mathrm{BOCX} 9852$ ?

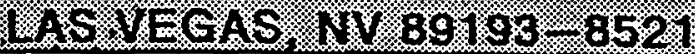

Request I Test Report

Requested by? D. MADSEN

User/Agency: BECHTEL

$\log \# \quad$ N/A

Charge \#, C4P1CODE

MTL Lab \#: 1926

Project:

ITR AREA 3

Sampled by:

D. HERRINGTON

Material: NATIVE

Tested By:

T. HIGH \& D. JOHNSON

Checked by:

D. HERRINGTON

$2 \sum t \times$

Date Sampled: $07 / 15 / 98$

Date tested: $07 / 23 / 98$

Date checked: $10-1-98$

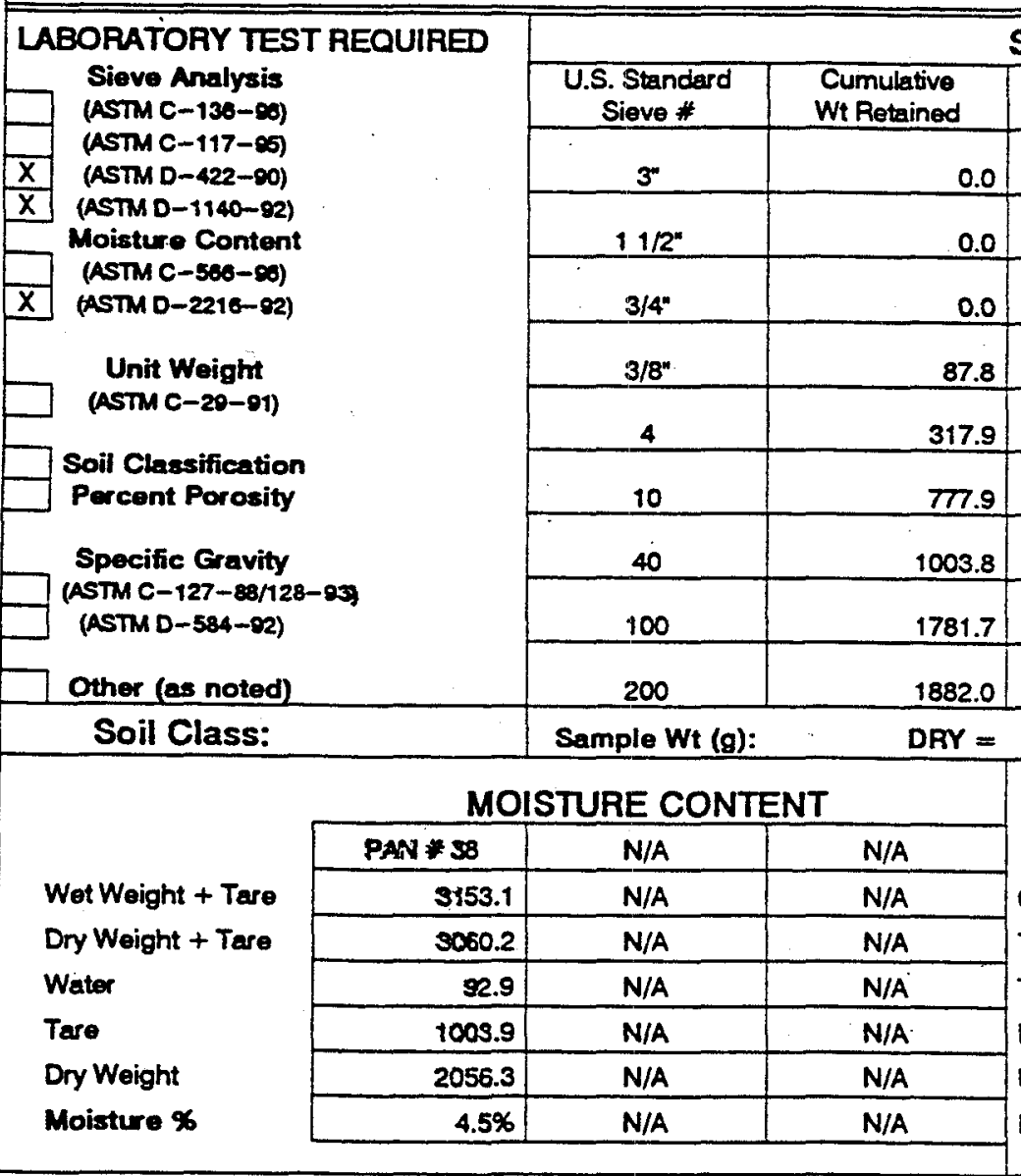

SIEVE ANALYSIS

Oversize Specific Gravity:

N/A

Container Size $\left(t^{\wedge}\right.$ 3)

Total Weight (lb)

Tare Weight (b)

Material Weight (b)

Unit Weight (P.C.F.)

Percent Porosity

\begin{tabular}{l|l|l} 
\% Retained : & \% Passing & $\begin{array}{l}\text { Spec \% } \\
\text { Passing }\end{array}$
\end{tabular}

\begin{tabular}{rr|r|r|r|r|}
$0 \%$ & $100 \%$ & N/A \\
\hline
\end{tabular}

EQUIPMENT USED: PM 16. PTL \#1256, Calibration Date: 06/02/98

Specific Gravity:

Calibration Due: 06/02/99

Sieve $11 / 2^{\prime \prime}$

Sieve 3/4"

Sieve 3/8

Sieve \# 4

Sieve \# 10

Sieve \# 16

Sieve \# 40

Sieve \# 100

Sieve \# 200
PTL \# Y303222 Cal. Date: 03/27/98 Cal. Due: 03/27/99 PTL \# Y303276 Cal. Date: 03/27/98 Cal. Due: 03/27/99 PTL \# Y302106 Cal. Date: 03/27/98 Cal. Due: 03/27/99 PTL \# Y302043 Cal. Date: 03/26/98 Cal. Due: 03/26/99 PTL\# Y11621 Cal. Date: 10/08/97 Cal. Due: 10/08/99 PTL \# Y302079 Cal. Date: 03/25/98 Cal. Due: 03/26/99 PTL\# Y106 Cal. Date: 10/09/97 Cal. Due: 10/09/99 PTL \# Y10035 Cal. Date: 05/21/98 Cal. Due: 05/21/99 PTL \# Y11599 Cal. Date: 10/09/97 Cal. Due: 10/09/99
REMARKS: NONE 


\begin{tabular}{|c|c|c|c|c|c|c|}
\hline 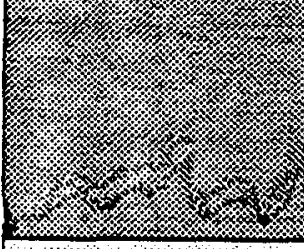 & . & 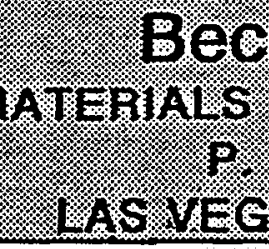 & 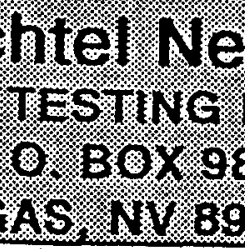 & 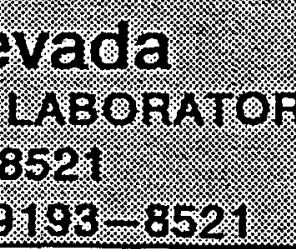 & $\frac{9}{2}$ & \\
\hline Request / T & est Report & अ४ & & & & \\
\hline Requested by: & D.MADSEN & & & Charge \#, & CAP 1CODE & \\
\hline User/Agency: & BECHTEL & Log. & N/A & MTL Lab \#: & 1927 & \\
\hline Project: & TTR AREA 3 & & & Material: & NATIVE & $A 3-6 / 2$ \\
\hline Sampled by: & D. HERRINGT & ON & & Date Sampled: & $07 / 15 / 98$ & \\
\hline Tested By: & T.HIGH \&D.J & JOHNSON & & Date tested: & $07 / 23 / 98$ & \\
\hline Checked by: & D. HERRINGT & ON $\mathrm{QN}\}$ & & Date checked: & $10-1-98$ & \\
\hline LABORATORY TES & TREQUIRED & & & SIEVE ANALYSIS & & \\
\hline 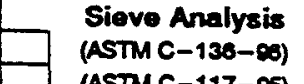 & & $\begin{array}{l}\text { U.S. Standard } \\
\text { Sieve \# }\end{array}$ & $\begin{array}{c}\text { Cumulative } \\
\text { Wt Retained }\end{array}$ & $\%$ Retained & \% Passing & $\begin{array}{l}\text { Spoc } \% \\
\text { Passing }\end{array}$ \\
\hline 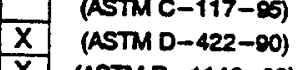 & & $3^{\prime \prime}$ & 0.0 & $0 \%$ & $100 \%$ & N/A \\
\hline $\begin{array}{l}\text { X (ASTM D-1140-92) } \\
\text { Moisture Content }\end{array}$ & & $11 / 2^{n}$ & 0.0 & $0 \%$ & $100 \%$ & N/A \\
\hline 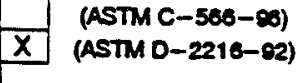 & & $3 / 4^{4}$ & 0.0 & $0 \%$ & $100 \%$ & N/A \\
\hline Unit Weight & & $3 / 8^{\prime \prime}$ & 113.4 & $5 \%$ & $95 \%$ & N/A \\
\hline (ASTM C-29-01) & & 4 & 298.1 & $14 \%$ & $86 \%$ & N/A \\
\hline $\begin{array}{l}7 \text { Soil Classification } \\
\text { Percont Porosity }\end{array}$ & & 10 & 542.1 & $25 \%$ & $75 \%$ & $N / A$ \\
\hline Specific Gravity & & 40 & 988.1 & $45 \%$ & $55 \%$ & $N / A$ \\
\hline $\begin{array}{l}\text { (ASTM C- } 127-88 / 128 \\
\text { (ASTM D-584-92) }\end{array}$ & & 100 & 1384.8 & $64 \%$ & $36 \%$ & N/A \\
\hline 7 other (as noted) & & 200 & 1634.4 & $75.2 \%$ & $24.8 \%$ & N/A \\
\hline Soil Class: & & Sample Wt (g): & DRY $=$ & 2173.3 & WET $=$ & N/A \\
\hline & $\mathrm{MO}$ & ISTURE CONTE & ENT & & UNIT WE & EIGHT \\
\hline & PAN \# 39 & N/A & $N / A$ & & Loose & Rodded \\
\hline Wet Weight + Tare & 3152.8 & N/A & $N / A$ & Container Size $\left(t^{\wedge} \leadsto\right)$ & N/A & N/A \\
\hline Dry Weight + Tare & 3048.6 & N/A. & $N / A$ & Total Weight (lb) & $N / A$ & $N / A$ \\
\hline Water & 104.2 & N/A & N/A & Tare Weight (lb) & N/A & N/A \\
\hline Tare & 875.3 & N/A & N/A & Material Weight (b) & N/A & N/A \\
\hline Dry Weight & 2173.3 & N/A & N/A & Unit Weight (P.C.F.) & N/A & $N / A$ \\
\hline Moisture $\%$ & $4.8 \%$ & N/A & N/A & Percent Porosity & N/A & N/A \\
\hline Oversize Specific & Gravity: & N/A & & Specific Gravity: & N/A & \\
\hline EQUIPMENT USED: & PM 16, PTL \#1256. & Calibration Date: & $06 / 02 / 98$ & Calibration Due: $06 / 02 / 5$ & & \\
\hline Sieve $11 / 2^{n}$ & PTL\# Y303222 & Cal. Date: $03 / 27 / 98$ & Cal. Due: 03/27/99 & REMARKS: & NONE & \\
\hline Sieve 3/4" & PTL \# Y303276 & Cal. Date: 03/27/98 & Cal. Due: 03/27/99 & & & \\
\hline Sieve $3 / 8$ & PTL \# Y302106 & Cal. Date: 03/27/98 & Cal. Due: 03/27/99 & & & \\
\hline Sieve \# 4 & PTL\# Y302043 & Cal. Date: 03/26/98 & Cal. Due: 03/26/99 & & & \\
\hline Sieve \# 10 & PTL\# Y11621 & Cal. Date: $10 / 08 / 97$ & Cal. Due: 10/08/99 & & & \\
\hline Sieve \# 16 & PTL \# Y302079 & Cal. Date: 03/25/98 & Cal. Due: 03/26/99 & & & \\
\hline Sieve \# 40 & PTL \# Y106 & Cal. Date: 10/09/97 & Cal. Due: 10/09/99 & & & \\
\hline Sieve \# 100 & PTL\# Y10035 & Cal. Date: $05 / 21 / 98$ & Cal. Due: 05/21/99 & & & \\
\hline Sieve \# 200 & PTL \# Y11599 & Cal. Date: 10/09/97 & Cal. Due: 10/09/99 & & & \\
\hline & & & & & & \\
\hline
\end{tabular}




\begin{tabular}{|c|c|c|c|c|c|c|}
\hline 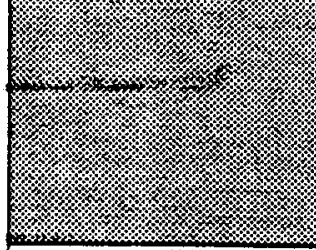 & l. & 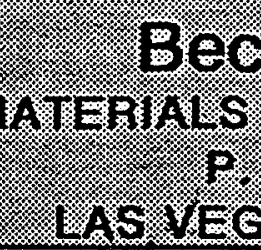 & 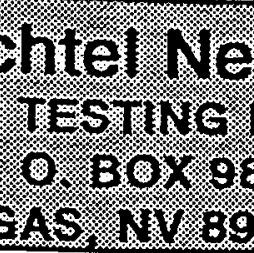 & 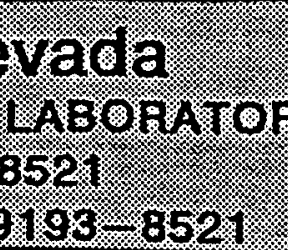 & & \\
\hline Request $/ \mathrm{T}$ & est Report & & & & & \\
\hline Requested by: & D. MADSEN & & & Charge \#: & CAPICODE & \\
\hline User/Agency: & BECHTEL & $\log \#$ & $\mathrm{~N} / \mathrm{A}^{2}$, & MTL Lab \#: & 1928 & \\
\hline Project: & TIR AREA 3 & & & Material: & NATIVE & $A 3-8 / 1$ \\
\hline Sampled by: & D. HERRINGT & & & Date Sampled: & $07 / 15 / 98$ & \\
\hline Tested By: & T. HIGH \& D.J & JOHNSON & & Date tested: & $07 / 23 / 98$ & \\
\hline Checked by: & D. HERRINGT & ON DLK. & & Date checked: & $10-1-98$ & \\
\hline LABORATORY TES & T REQUIRED & & & SIEVE ANALYSIS & & \\
\hline 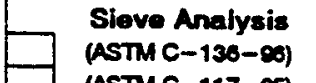 & & $\begin{array}{l}\text { U.S. Standard } \\
\text { Sieve \# }\end{array}$ & $\begin{array}{l}\text { Cumulative } \\
\text { Wt Retained }\end{array}$ & \% Retained & $\%$ Passing & $\begin{array}{l}\text { Spec \% } \\
\text { Passing }\end{array}$ \\
\hline \begin{tabular}{|l|}
$X$ \\
\cline { 1 - 2 } \\
\cline { 1 - 1 }
\end{tabular} & & $3^{*}$ & 0.0 & $0 \%$ & $100 \%$ & N/A \\
\hline \begin{tabular}{|l}
$X$ (ASTM D-1140-92) \\
Moisture Comtont
\end{tabular} & & $11 / 2^{*}$ & 0.0 & $0 \%$ & $100 \%$ & N/A \\
\hline \begin{tabular}{|l|}
$X$ \\
(ASTM D-2216-92)
\end{tabular} & & $3 / 4^{\prime \prime}$ & 0.0 & $0 \%$ & $100 \%$ & N/A \\
\hline Unit Woight & & $3 / 8^{*}$ & 161.5 & $8 \%$ & $92 \%$ & N/A \\
\hline (ASTM C-29-01) & & 4 & 375.2 & $20 \%$ & $80 \%$ & N/A \\
\hline $\begin{array}{l}\text { Soil Classification } \\
\text { Percent Porosity }\end{array}$ & & 10 & 738.6 & $38 \%$ & $62 \%$ & N/A \\
\hline Specific Gravity & & 40 & 1303.4 & $68 \%$ & $32 \%$ & N/A \\
\hline $\begin{array}{l}\text { (ASTM C-127-88/128 } \\
\text { (ASTM D-584-92) }\end{array}$ & & 100 & 1513.3 & $79 \%$ & $21 \%$ & N/A \\
\hline Other (es noted) & & 200 & 1643.5 & $85.5 \%$ & $14.5 \%$ & N/A \\
\hline Soil Class: & & Sample Wt (g): & DRY $=$ & 1922.7 & WET $=$ & $N / A$ \\
\hline & MOI & ISTURE CONTE & ENT & & UNIT W & EIGHT \\
\hline & PAN \# 40 & N/A & N/A & & Loose & Rodded \\
\hline Wet Weight + Tare & 2941.3 & N/A & $N / A$ & Container Size $\left(t^{\prime} \wedge\right.$ 3) & N/A & N/A \\
\hline Dry Weight + Tare & 2795.6 & N/A & N/A & Total Weight (lb) & N/A & N/A \\
\hline Water & 145.7 & N/A & N/A & Tare Weight (lb) & N/A & N/A \\
\hline Tare & 872.9 & N/A & N/A & Material Weight (b) & N/A & N/A \\
\hline Dry Weight & 1922.7 & N/A & N/A & Unit Weight (P.C.F.) & N/A & N/A \\
\hline Moisture X & $7.6 \%$ & N/A & N/A & Percent Porosity & N/A & N/A \\
\hline Oversize Specific & Gravity: & N/A & & Specific Gravity: & N/A & \\
\hline EQUIPMENT USED: $P$ & PM 16, PTL \#1256. & Calibration Date: & $06 / 02 / 98$ & Calibration Due: $06 / 02 / 5$ & & \\
\hline Sieve $11 / 2^{m}$ & PTL \# Y303222 & Cal. Date: 03/27/98 & Cal. Due: 03/27/99 & REMARKS: & NONE & \\
\hline Sieve $3 / 4^{n}$ & PTL\# Y303276 & Cal. Date: $03 / 27 / 98$ & Cal. Due: 03/27/99 & & & \\
\hline Sieve 3/8 & PTL \# Y302106 & Cal. Date: 03/27/98 & Cal. Due: 03/27/99 & & & \\
\hline Sieve \# 4 & PTL \# Y302043 & Cal. Date: 03/26/98 & Cal. Due: 03/26/99 & & & \\
\hline Sieve \# 10 & PTL \# Y11621 & Cal. Date: 10/08/97 & Cal. Due: 10/08/99 & & & \\
\hline Sieve \# 16 & PTL \# Y302079 & Cal. Date: $03 / 25 / 98$ & Cal. Due: 03/26/99 & & & \\
\hline Sieve \# 40 & PTL\#Y106 & Cal. Date: 10/09/97 & Cal. Due: 10/09/99 & & & \\
\hline Sieve \#100 & $P T L \# Y 10035$ & Cal. Date: 05/21/98 & Cal. Due: 05/21/99 & & & \\
\hline Sieve \# 200 & PTL\# Y11599 & Cal. Date: 10/09/97 & Cal. Due: 10/09/99 & & & \\
\hline
\end{tabular}




\begin{tabular}{|c|c|c|c|c|c|c|}
\hline 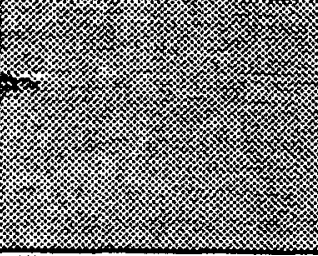 & 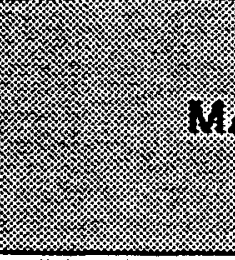 & 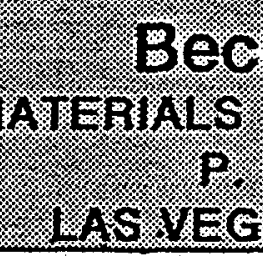 & 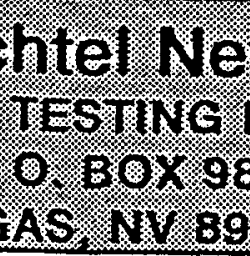 & 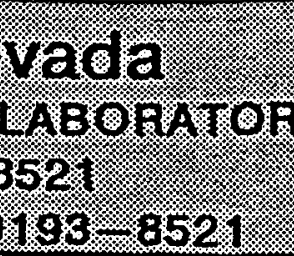 & & \\
\hline Request / Te & est Report & & & & & \\
\hline Requested by: & D. MADSEN & & & Charge \#: & C4P 1CODE & \\
\hline User/Agency? & BECHTEL & $\log \#$ & N/A & $M T L \mathrm{Lab} \#:$ & 1929 & \\
\hline Project: & TIR AREA 3 & & & Material: & NATIVE & $A 3-8 / 2$ \\
\hline Sampled by: & D. HERRINGTC & ON & - & Date Sampled: & $07 / 15 / 98$ & \\
\hline Tested By: & T. HIGH \& D.J & JOHNSON & & Date tested: & $07 / 23 / 98$ & \\
\hline Checked by: & D. HERRINGTC & ON Dex & & Date checked: & $10-1.98$ & \\
\hline LABORATORY TEST & REQUIRED & & & SIEVE ANALYSIS & & \\
\hline 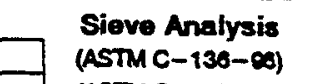 & & $\begin{array}{c}\text { U.S. Standard } \\
\text { Sieve \# }\end{array}$ & $\begin{array}{l}\text { Cumulative } \\
\text { Wt Retained }\end{array}$ & \% Retained & \% Passing & $\begin{array}{l}\text { Spec } \% \\
\text { Passing }\end{array}$ \\
\hline $\begin{array}{l}\text { (ASTM C-117-8) } \\
X \quad \text { (ASTM } D-422-80)\end{array}$ & & $3^{*}$ & 0.0 & $0 \%$ & $100 \%$ & N/A \\
\hline $\begin{array}{l}X \text { (ASTM D-1140-92) } \\
\text { Moisture Content }\end{array}$ & & $11 / R^{\prime \prime}$ & 0.0 & $0 \%$ & $100 \%$ & N/A \\
\hline $\begin{array}{l}\text { (ASTM C-566-8) } \\
X \quad \text { (ASTM D-2216-82) }\end{array}$ & & $3 / 4^{*}$ & 0.0 & $\alpha \%$ & $100 \%$ & N/A \\
\hline Unit Woight & & $3 / 8^{*}$ & 154.2 & $7 \%$ & $93 \%$ & N/A \\
\hline (ASTM C-29-91) & & 4 & 416.3 & 199 & $81 \%$ & N/A \\
\hline $\begin{array}{l}\text { Soil Classification } \\
\text { Percent Porosity }\end{array}$ & & 10 & 754.6 & $35 \%$ & $65 \%$ & $\frac{N / A}{N / A}$ \\
\hline Specific Gravity & & 40 & 1238.6 & $57 \%$ & $43 \%$ & N/A \\
\hline $\begin{array}{l}\text { (ASTM C-127- } 28 / 128) \\
\text { (ASTM D-5B4-92) }\end{array}$ & & 100 & 1584.1 & $73 \%$ & $27 \%$ & N/A \\
\hline Other (as noted) & & 200 & 1805.7 & $83.0 \%$ & $17.0 \%$ & N/A \\
\hline Soil Class: & & Sample Wt (g): & DRY = & 2175.6 & WET $=$ & N/A \\
\hline & MOI: & ISTURE CONTE & NT & & UNIT W & EIGHT \\
\hline & PAN \# 41 & $N / A$ & N/A & & Loose & Roodded \\
\hline Wet Weight + Tare & 3212.9 & N/A & N/A & Container Size $\left(t^{\wedge}\right.$ 3) & N/A & N/A \\
\hline Dry Weight + Tare & 3065.4 & N/A & N/A & Total Weight (lb) & N/A & N/A \\
\hline Water & 147.5 & N/A & $N / A$ & Tare Weight (lb) & N/A & N/A \\
\hline Tare & 889.8 & N/A & $N / A$ & Material Weight (lb) & N/A & N/A \\
\hline Dry Woight & 2175.6 & N/A & N/A & Unit Weight (P.C.F.) & N/A & N/A \\
\hline Moisture \% & $6.8 \%$ & N/A & N/A & Percent Porosity & N/A & $\overline{\text { N/A }}$ \\
\hline Oversize Specific & Gravity: & N/A & & Specific Gravity: & N/A & \\
\hline EQUIPMENT USED: PI & M 16. PTL \#1256. & Calibration Date: & 06/02/98 & Calibration Due: $06 / 02 / 5$ & & \\
\hline Sieve $11 / 2^{n}$ & PTL \# Y303222 & Cal. Date: 03/27/98 & Cal. Due: 03/27/99 & REMARKS: & NONE & 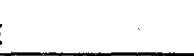 \\
\hline Sieve 3/4" & PTL \# Y303276 & Cal. Date: $03 / 27 / 98$ & Cal. Due: 03/27/99 & . & & \\
\hline Sieve 3/8 & PTL \# Y302106 & Cal. Date: 03/27/98 & Cal. Due: 03/27/99 & & & \\
\hline Sieve $* 4$ & $P T L \#$ Y302043 & Cal. Date: 03/26/98 & Cal. Due: $03 / 26 / 99$ & & & \\
\hline Sieve \# 10 & PTL\# Y11621 & Cal. Date: $10 / 08 / 97$ & Cal. Due: 10/08/99 & & & \\
\hline Sieve \# 16 & PTL \# Y302079 & Cal. Date: $03 / 25 / 98$ & Cal. Due: $03 / 26 / 99$ & & & \\
\hline Sieve \# 40 & PTL \# Y106 & Cal. Date: $10 / 09 / 97$ & Cal. Due: 10/09/99 & & 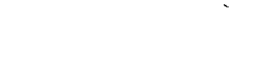 & \\
\hline Sieve \# 100 & PTL\# Y10035 & Cal. Date: 05/21/98 & Cal. Due: 05/21/99 & & & \\
\hline Sieve \# 200 & PTL\# Y11599 & Cal. Date: $10 / 09 / 979$ & Cal. Due: 10/09/99 & & & \\
\hline
\end{tabular}




\section{Bechtel Nevada

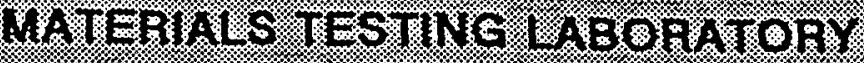 \\ P. (0. BOL 98521

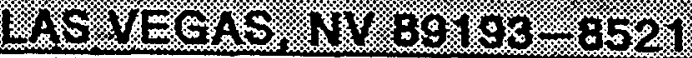

Request / Test Report

Requested by: D. MADSEN

User/Agency? BECHTEL

$\log \#$

N/A

Charge \#: 1 C4P1CODE

Project:

TIR AREA 3

Sampled by:

D. HERRINGTON

Tested By:

D. JOHNSON

Checked by:

D. HERRINGTON

Dls

MTLLab \#: 1987

Material: $\quad$ SANDIA BORROW PIT

Date Sampled: $07 / 28 / 98$

Date tested: $08 / 01 / 98$

Date checked: $10-1-98$

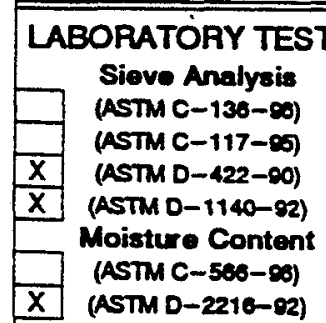

Unit Woight

(ASTM C-29-91)

Soil Classification

Percent Porosity

Specific Gravity

(ASTM C-127-88/128-93)

(ASTM D-584-92)

Other (as noted)

Soil Class:

REQUIRED

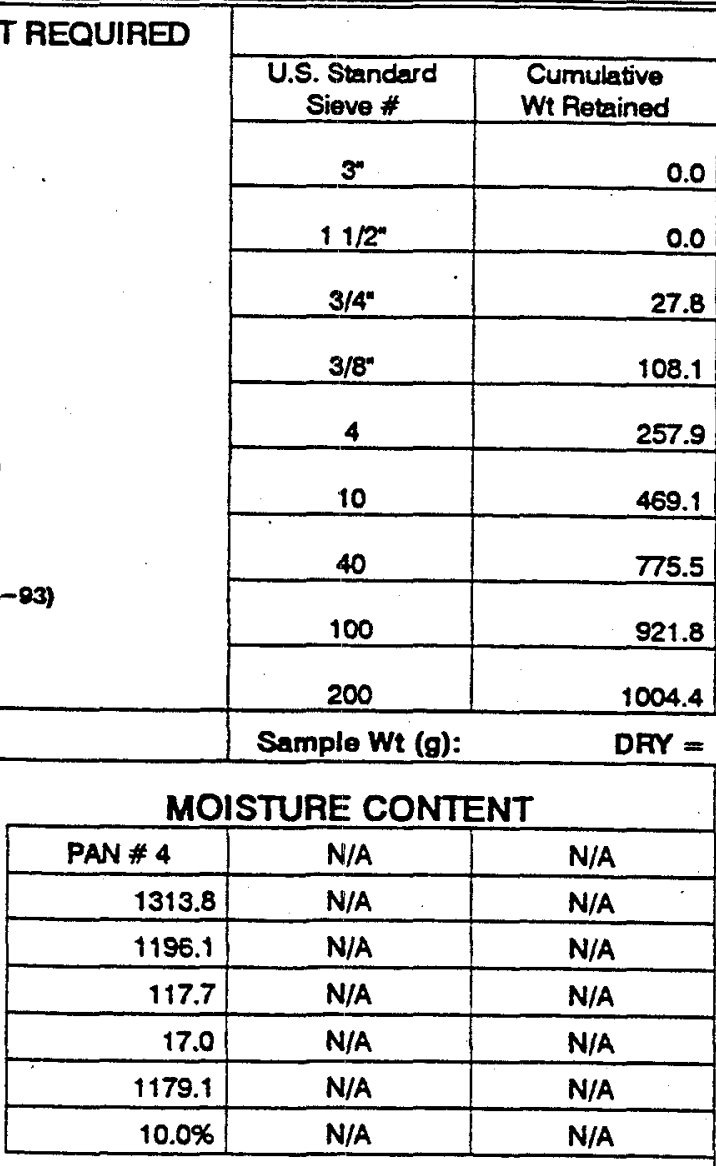

SIEVE ANALYSIS

\begin{tabular}{l|l|l} 
\% Retained : & Spec $\%$ \\
\hline
\end{tabular}

\begin{tabular}{r|r|r} 
& \% Passing & Passing \\
\hline $0 \%$ & $100 \%$ &
\end{tabular}

Wet Woight + Tere

Dry Weight + Tare

Water

Tare

Dry Weight

Moisture \%

Container Size(t: $\sim 3)$

Total Weight (lb)

Tare Weight (b)

Material Woight (lb)

Unit Weight (P.C.F.)

Percent Porosity

$100 \%$ N/A

N/A

Oversize Specific Gravity:

N/A

EQUIPMENT USED: PM 16, PTL \#1256, Calibration Date: 05/02/98

Specific Gravity:

$100 \%$ N/A

N/A

Sieve $11 / 2$

PTL \# Y303222 Cal. Date: 03/27/98 Cal. Due: 03/27/99

Calibration Due: 06/02/99

Sieve 3/4"

PTL \# Y303276 Cal. Date: 03/27/98 Cal. Due: 03/27/99

REMARKS:

NONE

Sieve 3/8

PTL \# Y302106 Cal. Date: 03/27/98 Cal. Due: 03/27/99

Sieve \# 4

PTL \# Y302043 Cal. Date: 03/26/98 Cal. Due: 03/26/99

Sieve \# 10

PTL \# Y11621 Cal. Date: 10/08/97 Cal. Due: 10/08/99

Sieve \# 16

PTL \# Y302079 Cal. Date: 03/25/98 Cal. Due: 03/26/99

Sieve \# 40

PTL \# Y106 Cal. Date: 10/09/97 Cal. Due: 10/09/99

Sieve \# 100

PTL \# Y10035 Cal. Date: 05/21/98 Cal. Due: 05/21/99

Sieve \# 200

PTL \# Y11599 Cal. Date: 10/09/97 Cal. Due: 10/09/99 


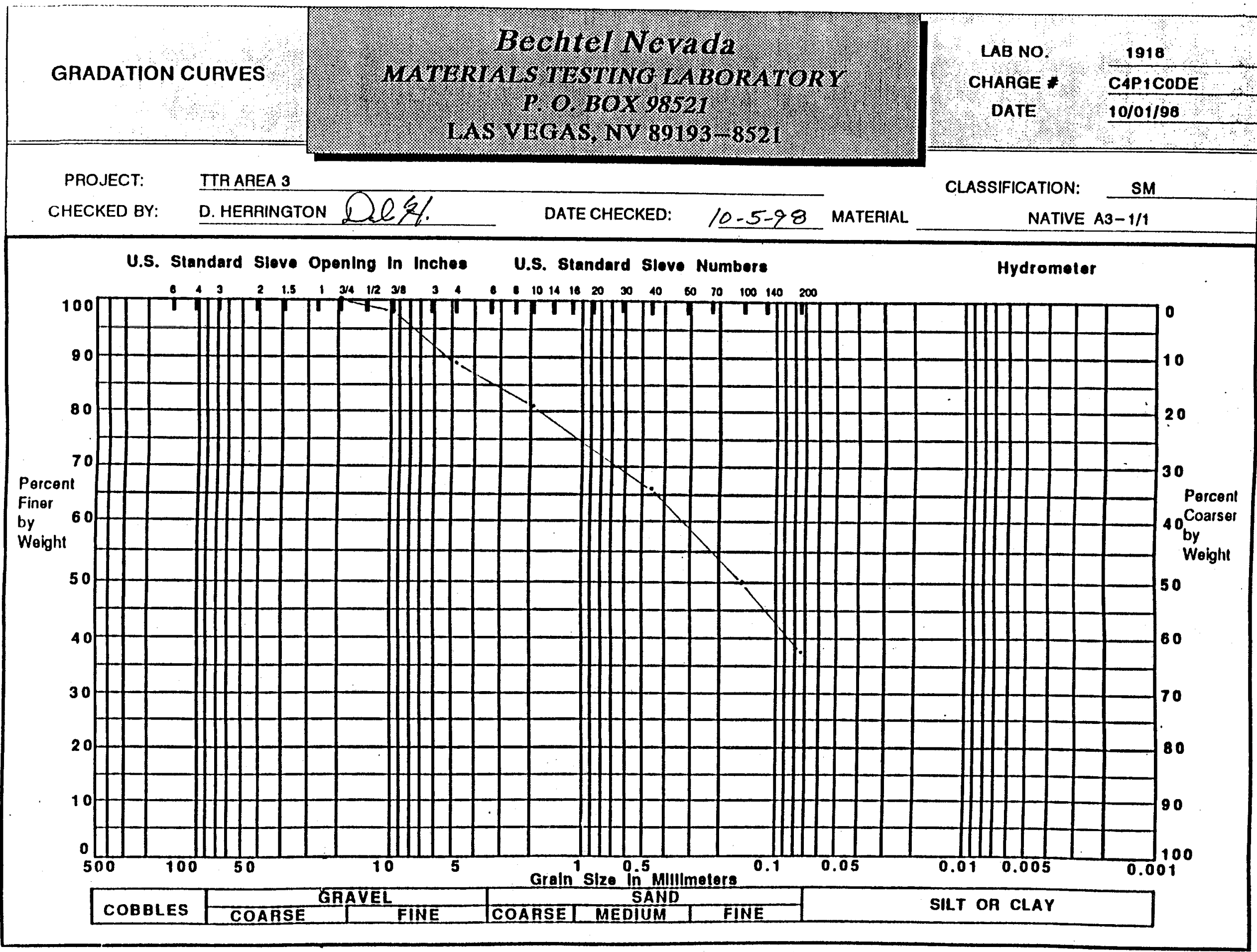



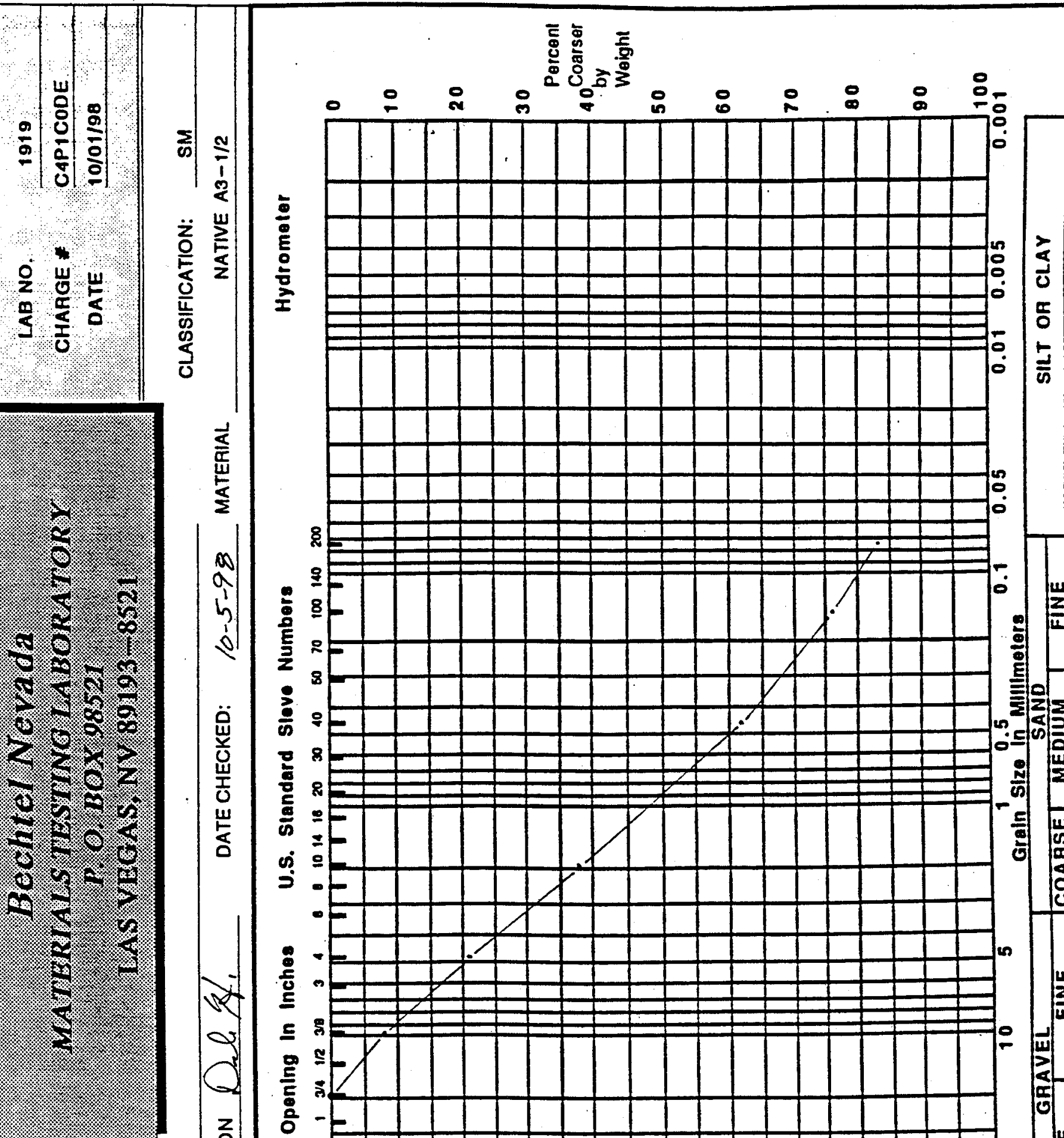

$\frac{\frac{1}{d}}{\frac{1}{6}}$

$\infty$

a

ol

影

을

它 $\frac{3}{0}$ ?
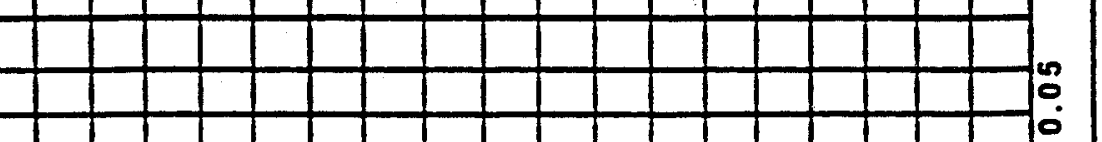

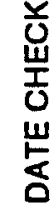

08

$\frac{8}{8} 8$
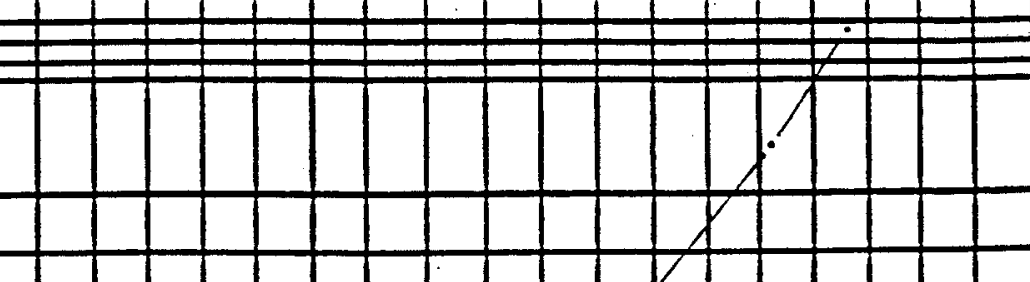

9

Nivi

क \pm

के

?

.

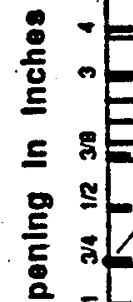

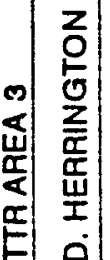

응-

en
UI
ㅍ

3

119

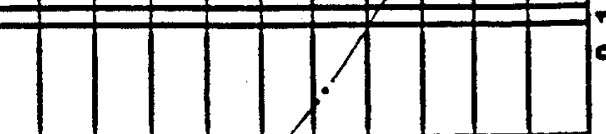

$=\frac{1}{2}$
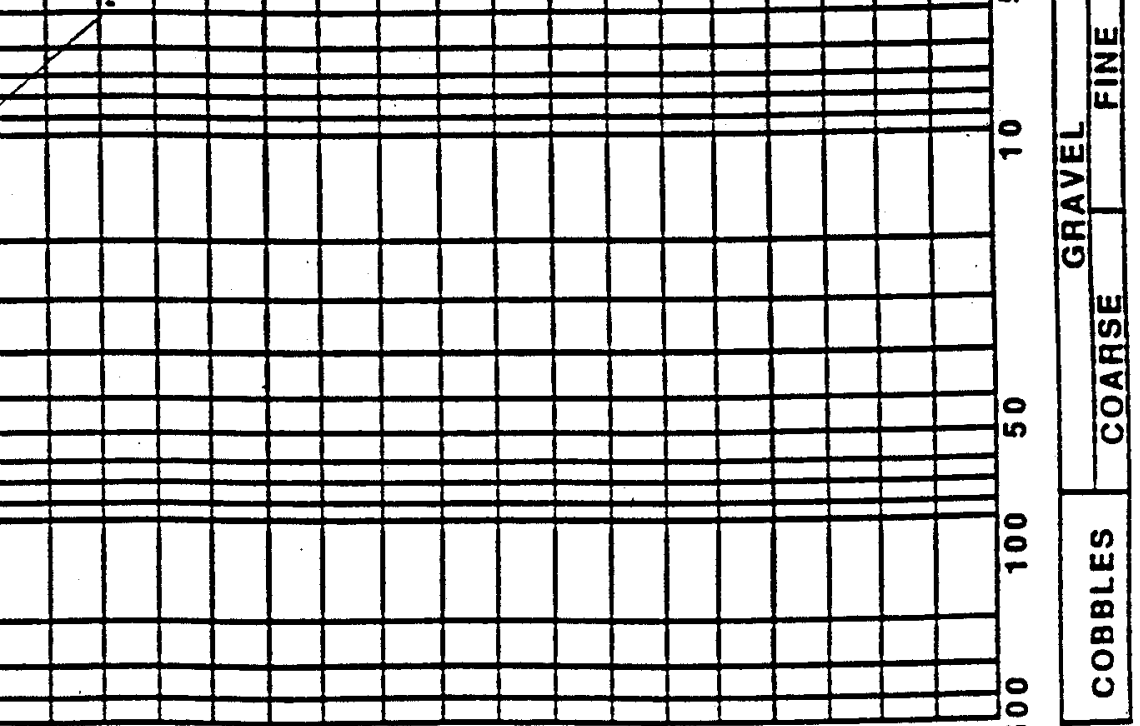

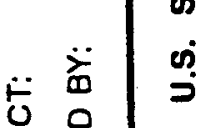

픈

O

a $\frac{1}{0}$
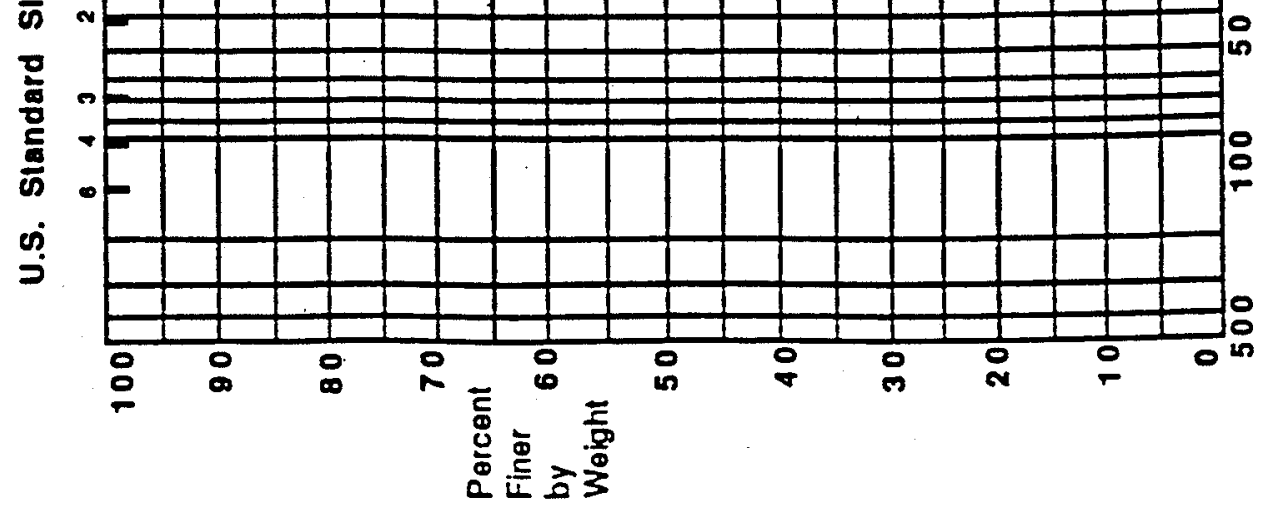


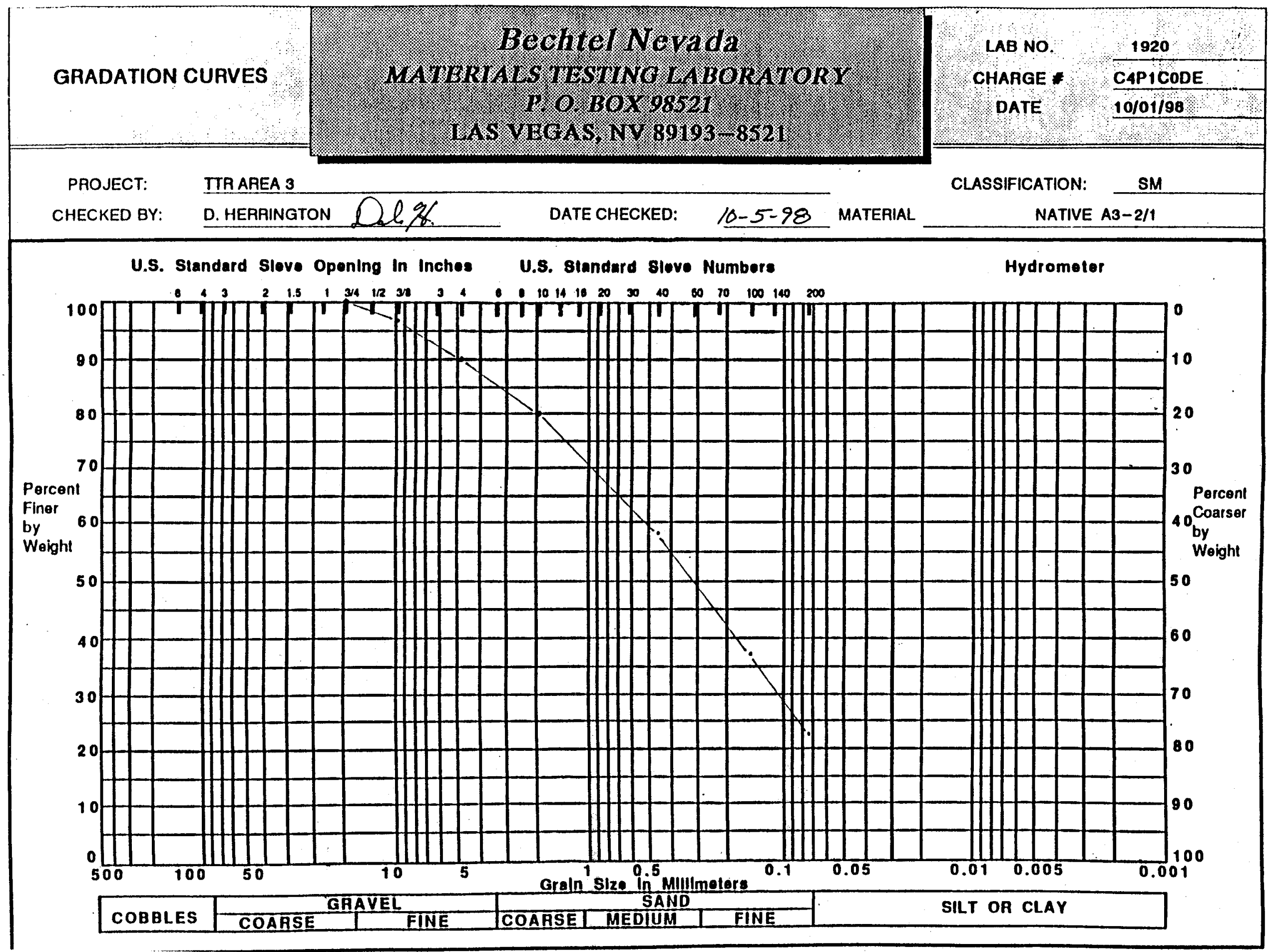




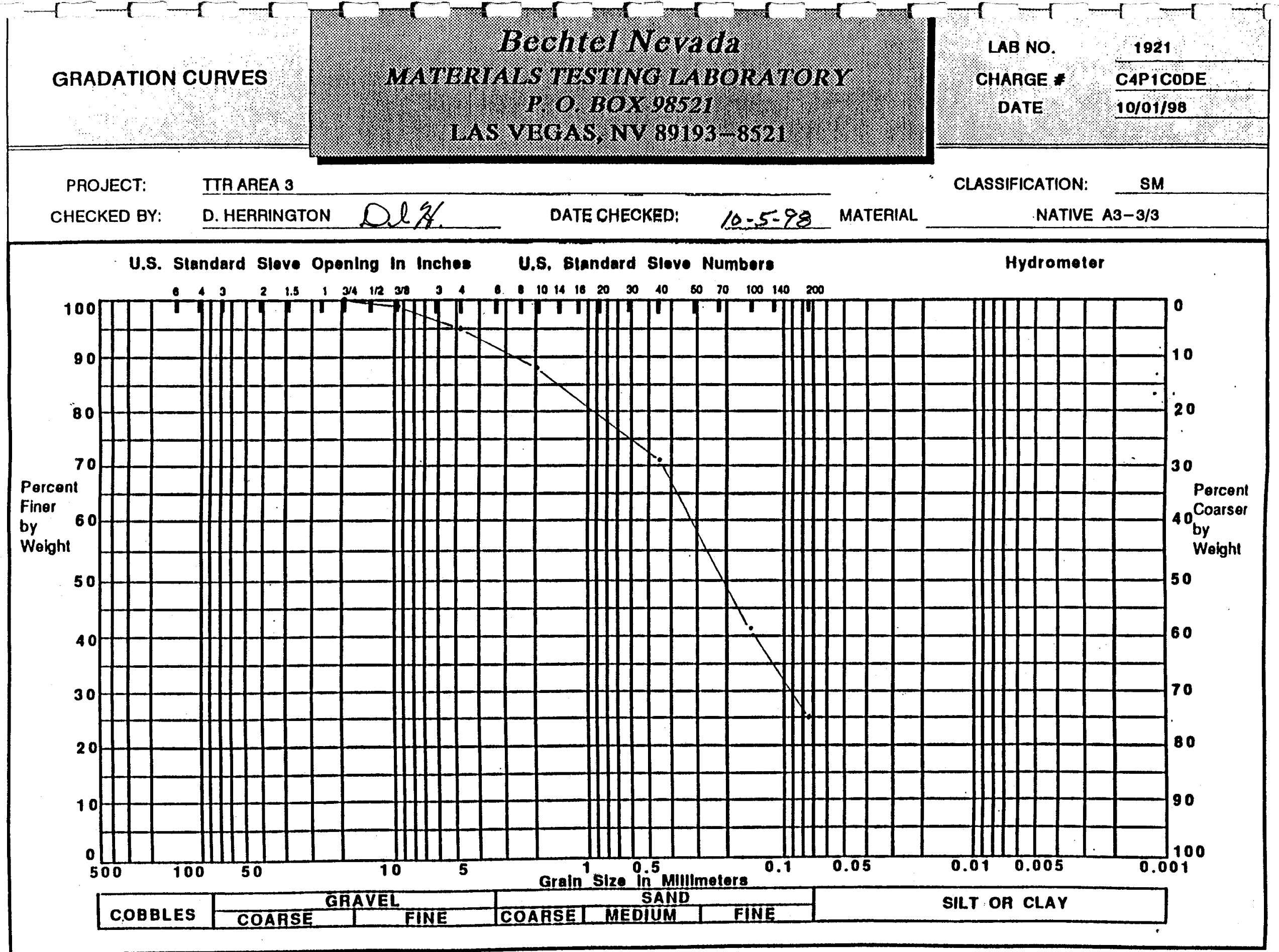




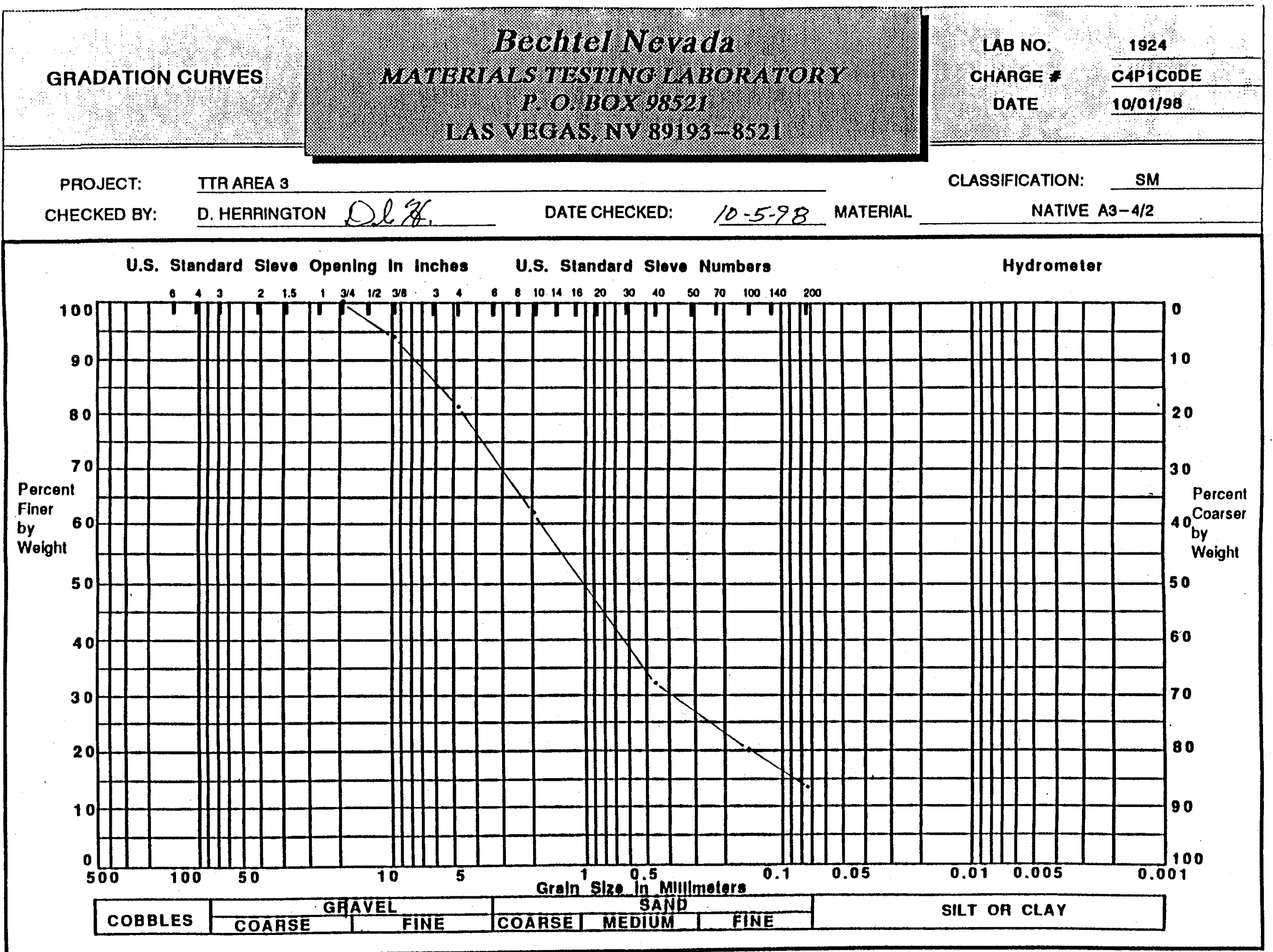




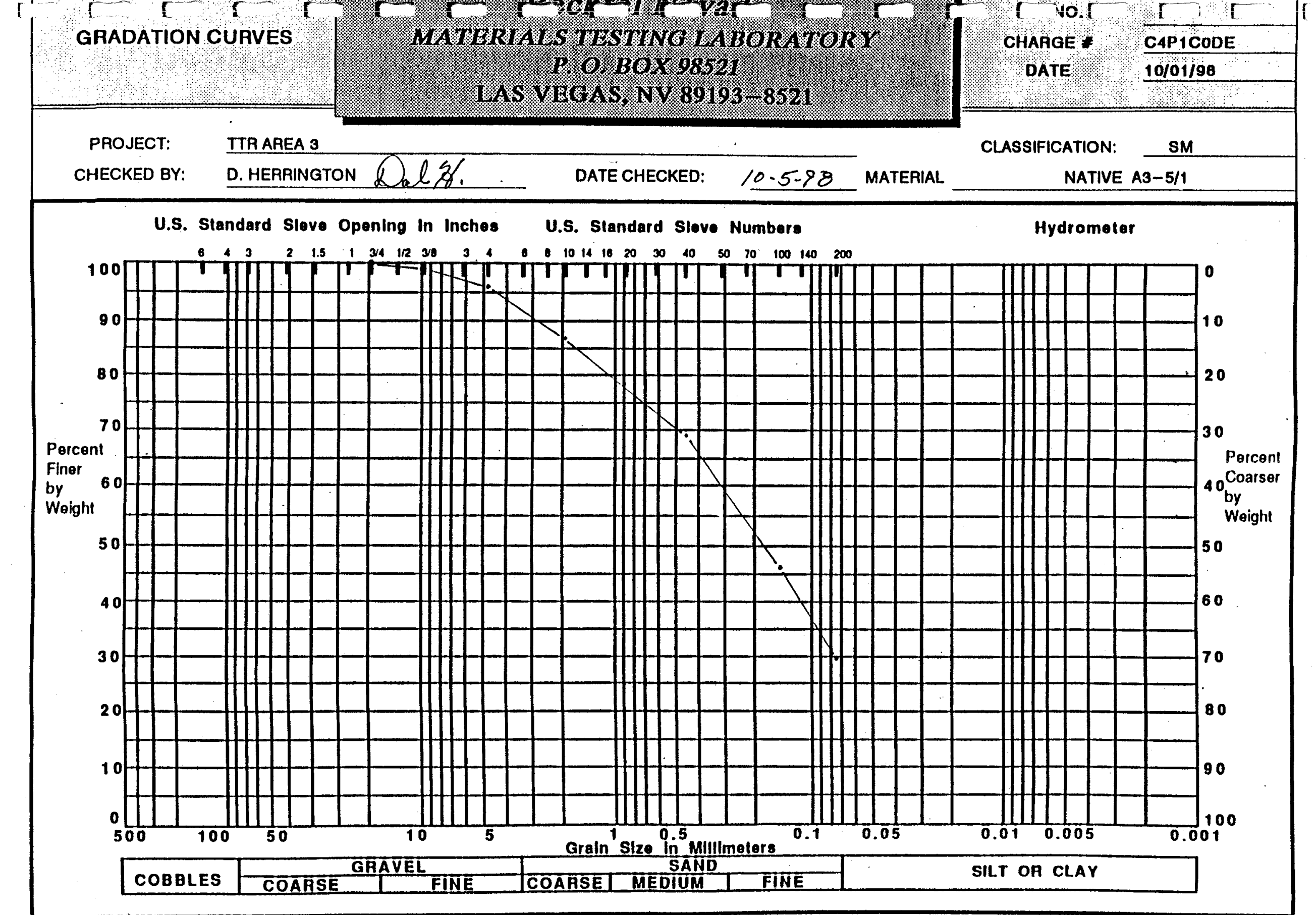




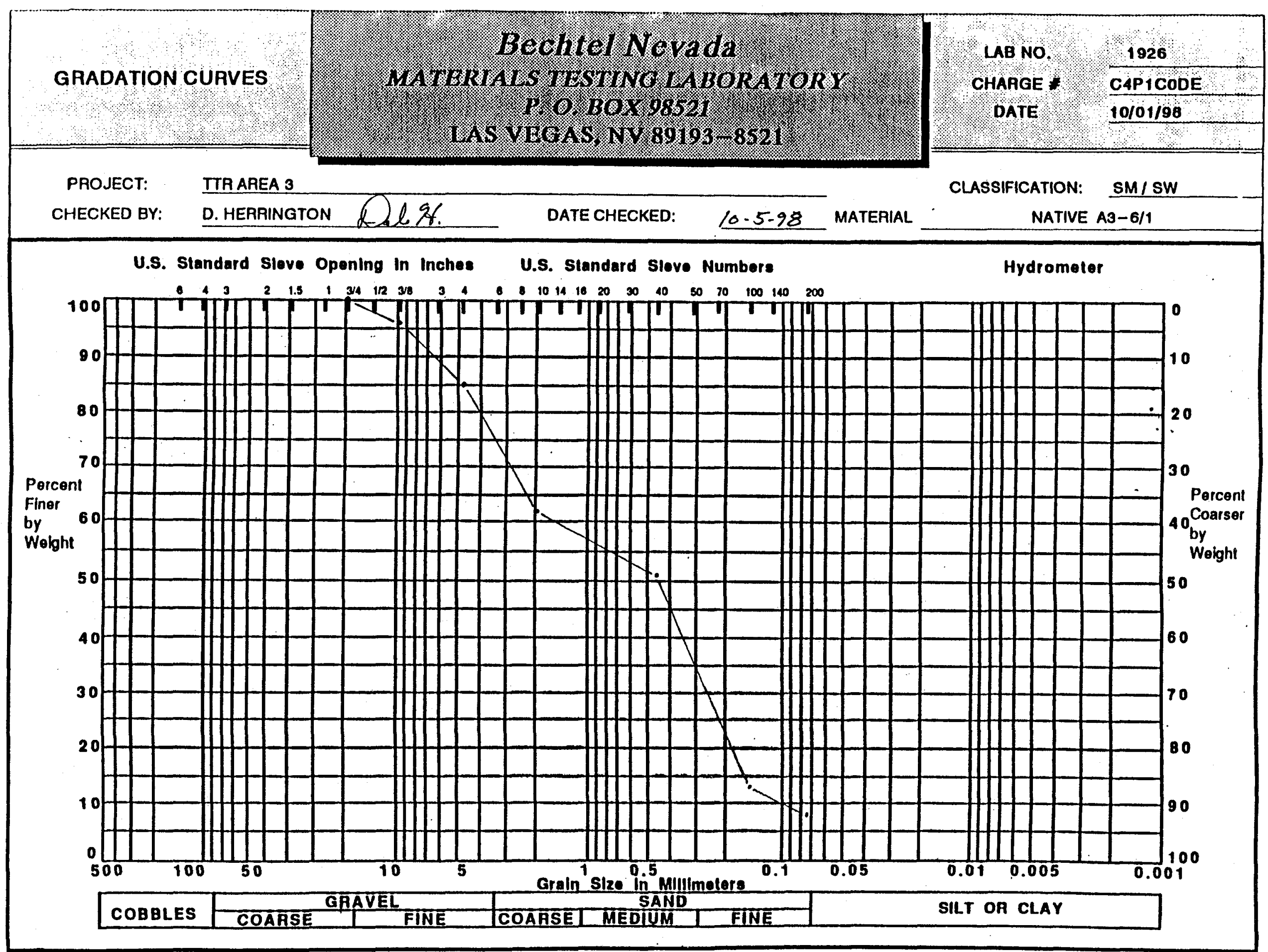




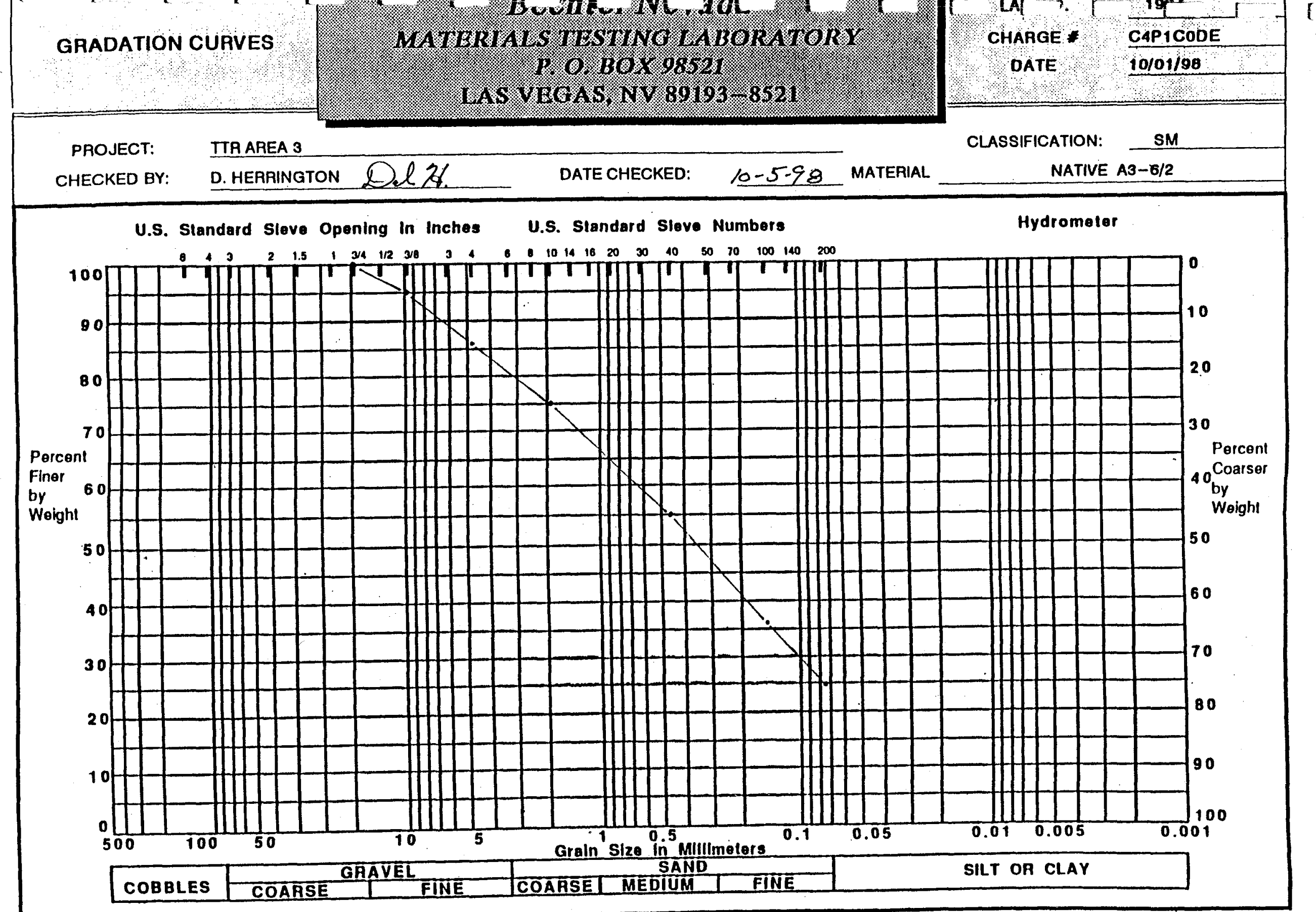




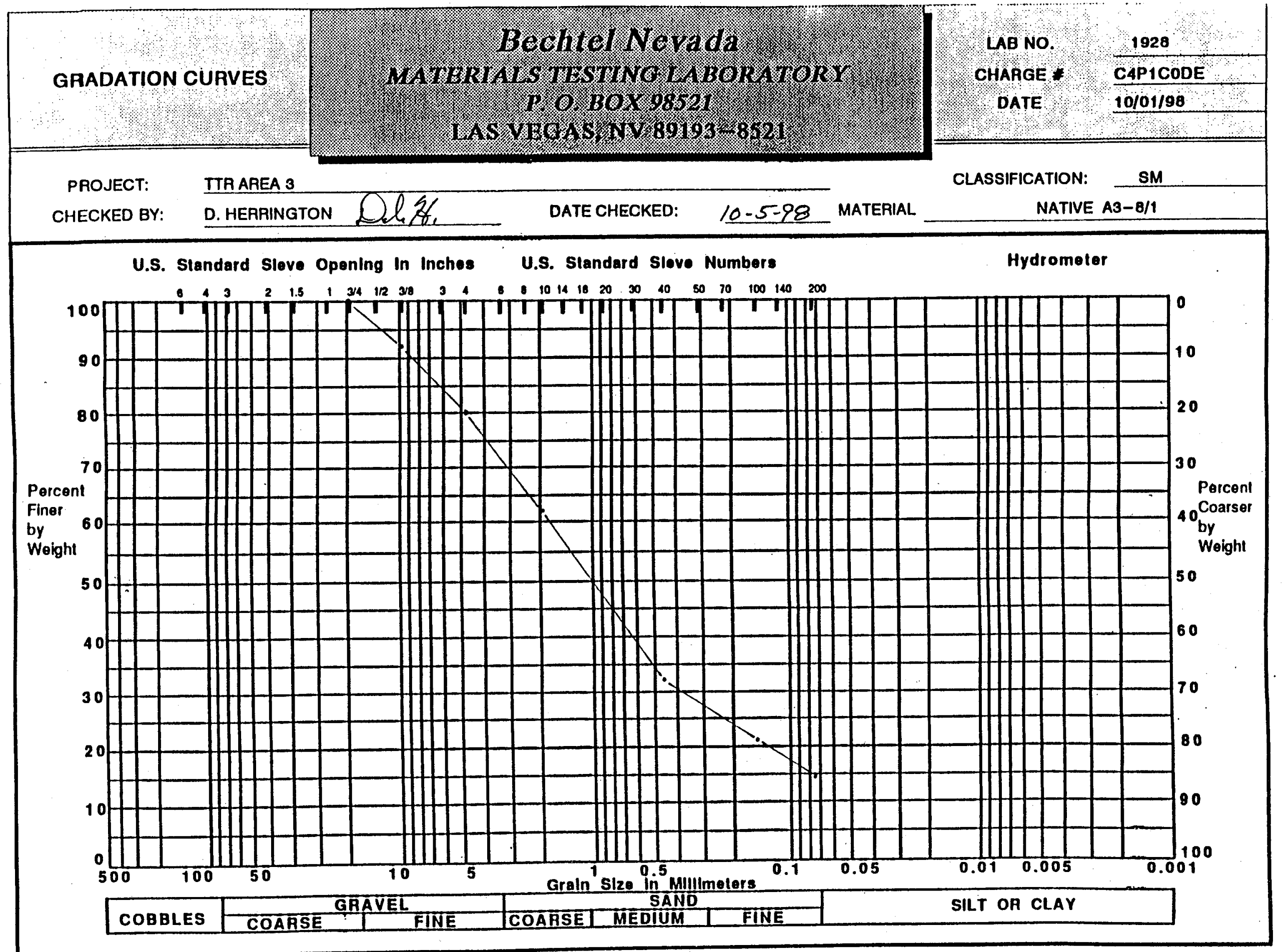




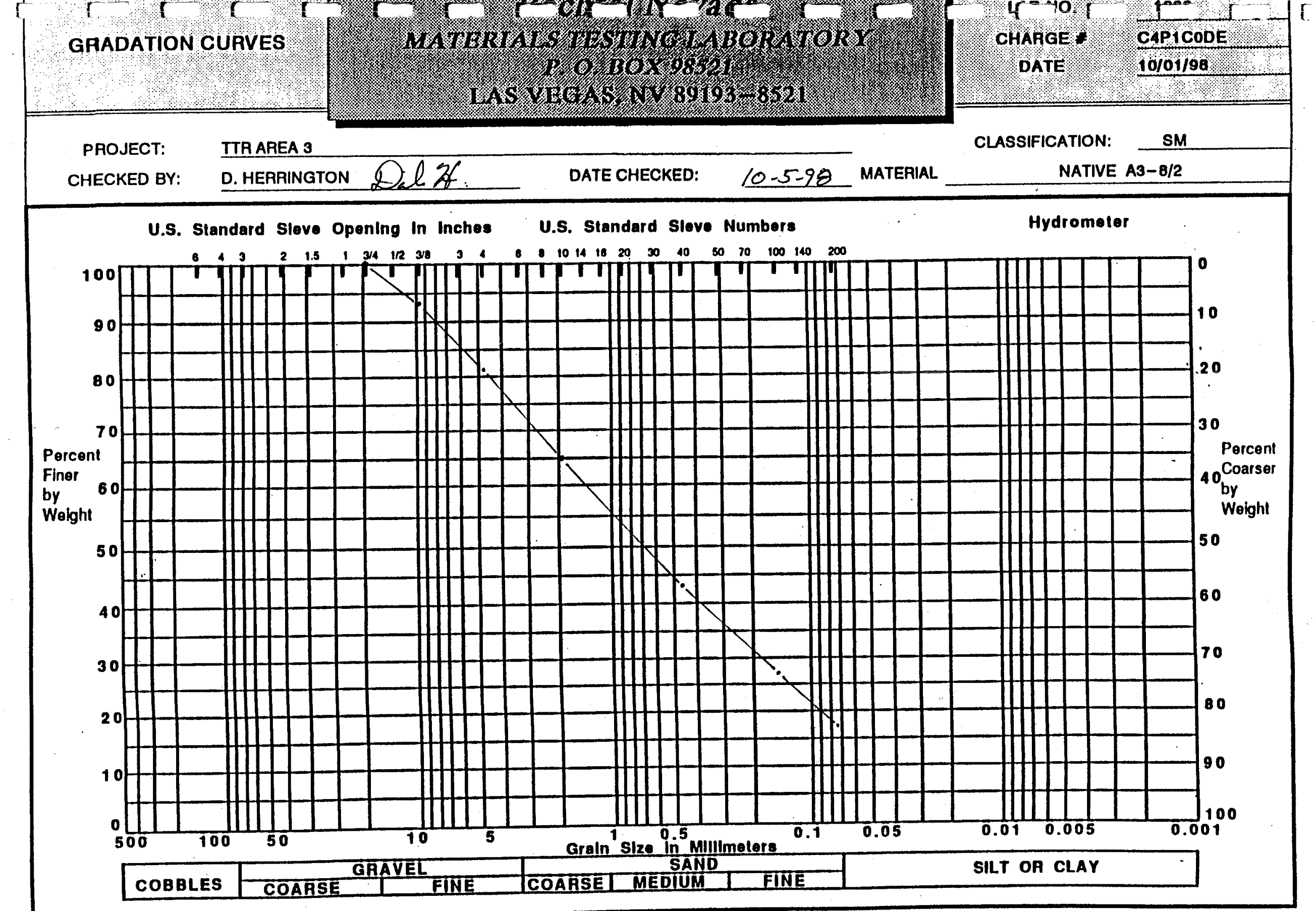




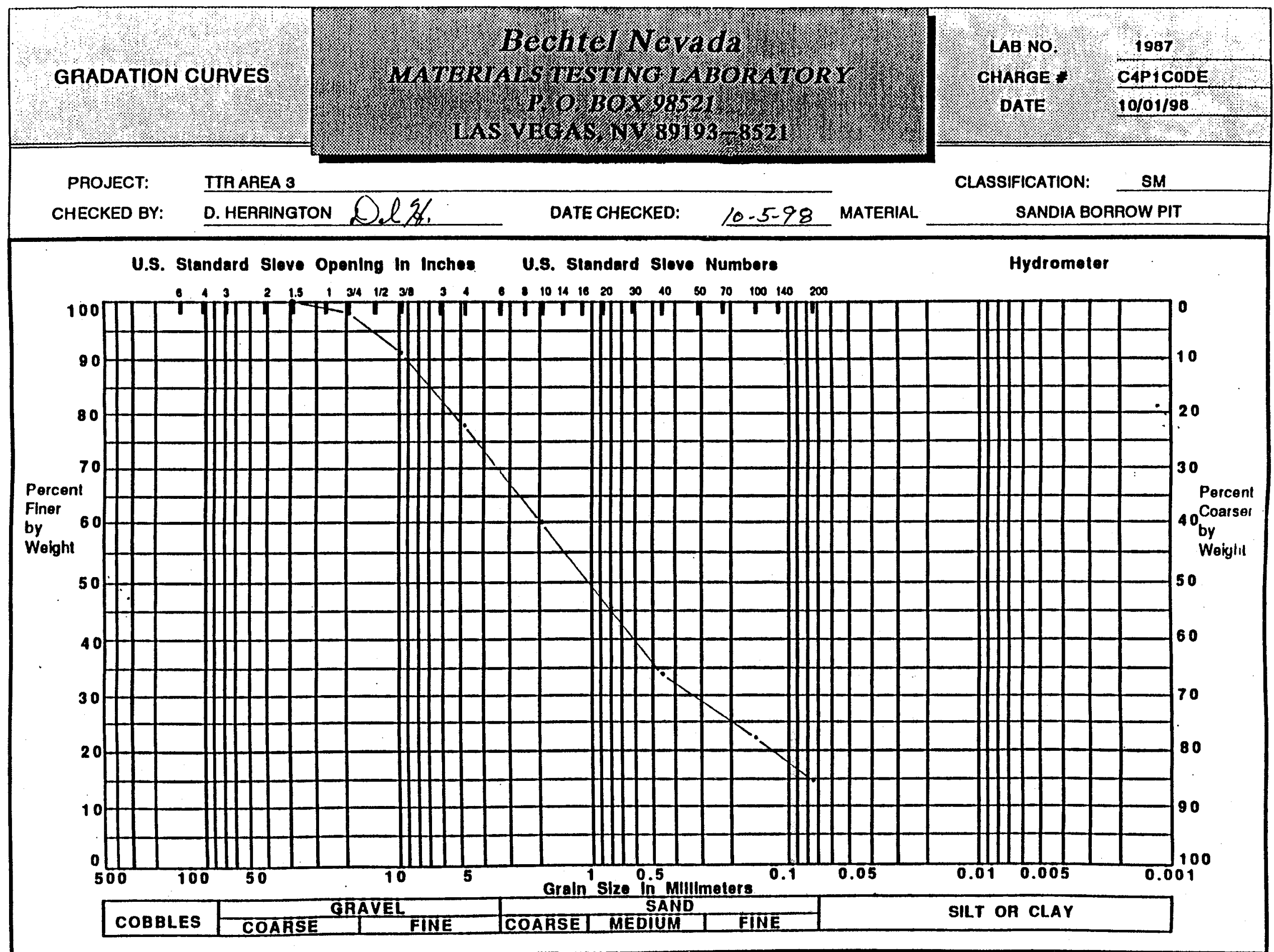




\section{NUGUEARDENSITY} ASTM 02922-96

CAMPBEH. MC- 2 MC-3.3 TROXIER:

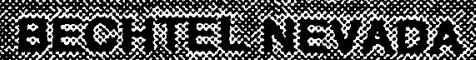

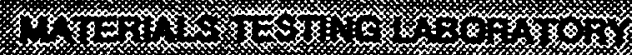

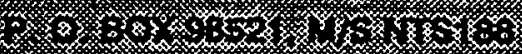

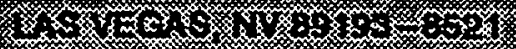

$0.1,15 \mathrm{E}$

$101110=0$

10.1E
10121000E

0713108

1.1 .001 .1

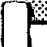

dequested by

D. FINNEY

User/Agency

BECHTEL

Material

SANDIA BORROW

'roject

TIR AREA 3

Location of Tests

TRENCH

Tested by

D. HERRINGTON

Date Tested 07/28/98

Checked by

nformation given to CURTISOBI By D. HERRINGTON How VERBAL

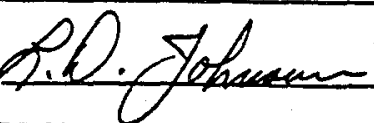

LABORATORY NO 1993

EST LOCATION

DEPTH OF PROBE

IEPTH OF TESTS Below grade

DRY DENSITY-PCF

1OISTURE \%

MAX DENSITY PCF

APTIMUM MOISTURE \%

ERCENT COMPACTION

REQUIRED COMPACTION \%

I IOUT OF SPECIFICATON

DATE OF STANDARDIZATION

GAUGENO

23205

\begin{tabular}{|c|c|c|c|}
\hline 1995 & 1996 & N/A & N/A \\
\hline$A 3-1 / T 3$ & $A 3-1 / T 4$ & & \\
\hline $12^{*}$ & $12^{*}$ & & \\
\hline $24^{\prime \prime}$ & $24^{*}$ & & \\
\hline 124.7 & 117.5 & & \\
\hline 8.2 & 9.1 & & \\
\hline 127.0 & 127.0 & & \\
\hline 9.5 & 9.5 & & \\
\hline 98.2 & 92.5 & & \\
\hline 80.0 & 80.0 & & \\
\hline WITHIN & WITHIN & & \\
\hline 98 & STANDAFDIZATION $\mathrm{D}$ & 2944 \\
\hline
\end{tabular}

PLOTPLAN

LMARKS:

A SAMPLE OF THE BORROW MATERIAL FROM THE SANDIA PIT WAS TAKEN AND ANEW PROCTOR WAS RUN. THE NEW PROCTOR RESULTS ARE SHOWN ABOVE.
CC: D. MADSEN BECHTEL MTL BECHTEL FILES 


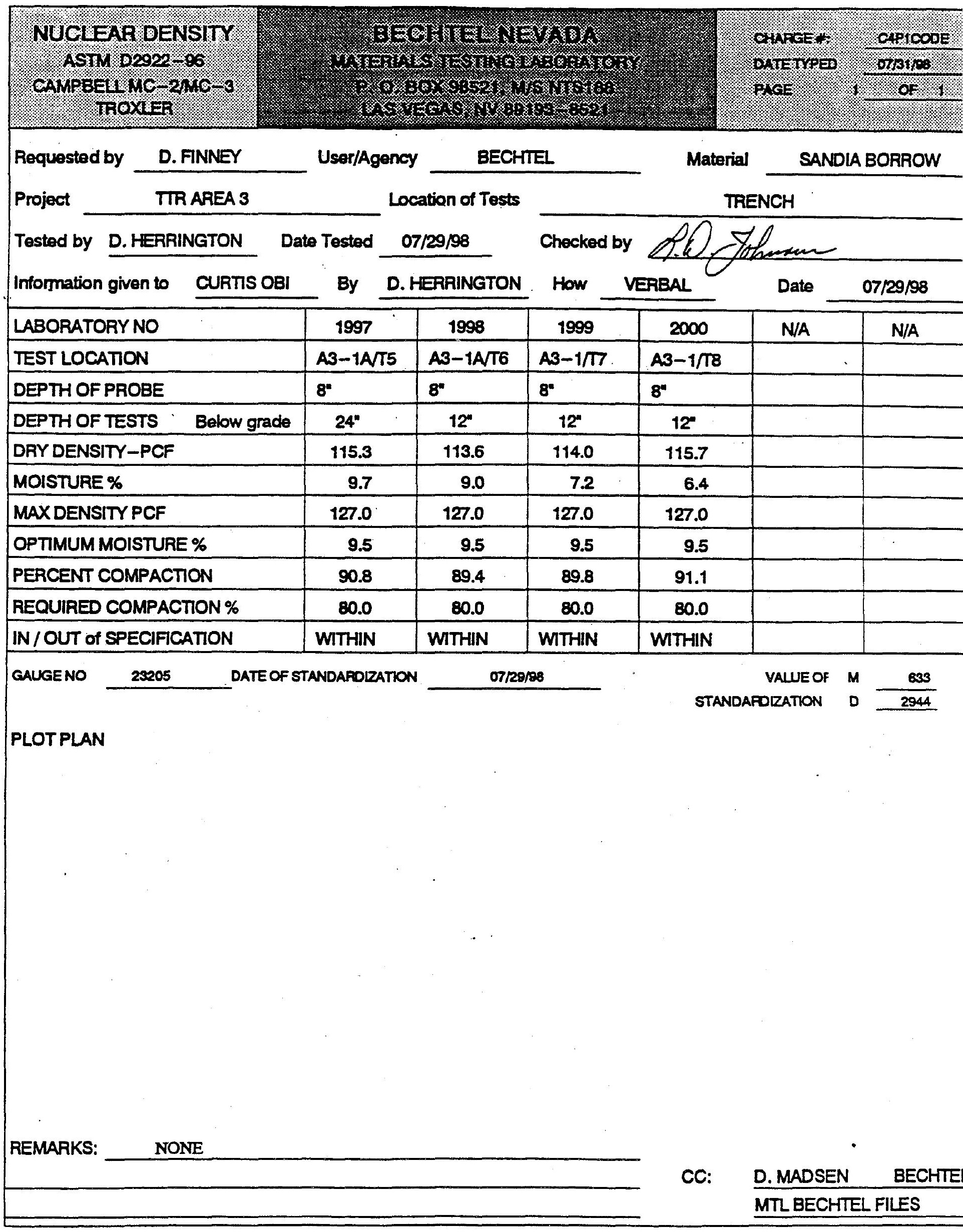


NUGLEARDENSTIT

$1511002922 \div 00$

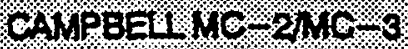

ThOX:En

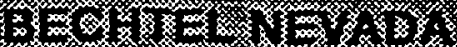

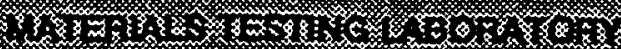

\%

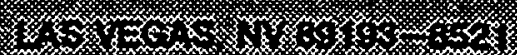

54Ptc000E

a8327t:0

1. .1 .0 .

Requested by

D. MADSEN

User/Agency

BECHTEL

Material

SANDIA BORROW

Project TIR AREA 3

Location of Tests

SEE BELOW

Tested by D.HERRINGTON Date Tested 08/13/98 Checked by

Information given to CURTIS OBI By

LABORATORYNO

TEST LOCATION

DEPTH OF PROBE

DEPTH OF TESTS

WET DENSITY-PCF

DRY DENSITY-PCF

MOISTURE\%

MAXDENSITY-PCF

OPTIMUM MOISTURE \%

PERCENT COMPACTION

REQUIRED COMPACTION \%

IN / OUT OF SPECIFICATION

2162

D. HERRINGTON

HOW VERBAL

Date

$08 / 13 / 98$

\begin{tabular}{|c|c|c|c|c|c|}
\hline 2162 & 2163 & 2164 & 2165 & 2166 & 2167 \\
\hline$A 3-2 / T 1$ & $A 3-2 / T 2$ & $A 3-2 / 13$ & A3-1AVT9 & $A 3-1 A \sqrt{1} 10$ & A3-1AVT11 \\
\hline $10^{*}$ & $12^{n}$ & $12^{\infty}$ & $12^{\prime \prime}$ & $12^{\prime \prime}$ & 12 \\
\hline
\end{tabular}

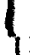

LABORATORYNO

TEST LOCATION

JEPTH OF PROBE

DEPTH OF TESTS

Final grade

Final grade

Final grade

122.7

116.9

115.0

109.5

121.9

Final grade

Final grade Final grade

$6.7 \%$

$6.8 \%$

114.1

121.9

125.6

123.0

114.9

117.9

115.6

$6.8 \%$

$6.1 \%$

$6.5 \%$

$6.4 \%$

127.0

127.0

127.0

127.0

127.0

127.0

9.5

9.5

9.5

90.6

86.2

89.8

80.0

80.0

80.0

\begin{tabular}{|l|l|}
\hline IN & IN \\
\hline
\end{tabular}

IN

\begin{tabular}{|r|r|}
\hline 9.5 \\
\hline 90.5 \\
\hline IN \\
\hline
\end{tabular}

9.5

9.5

9.5

90.5

92.8

91.0

80.0

80.0

80.0

$$
\text { VE }
$$

VET DENSITY-PCF

DRY DENSITY-PCF

1OISTURE $\%$

MAX DENSITY-PCF

IPTIMUM MOISTURE \%

TERCENT COMPACTION

PEQUIRED COMPACTION \%

$1 /$ OUT OF SPECIFICATION

AUGENO 23205

\begin{tabular}{|l|l}
\hline & \\
\hline & \\
\hline & \\
\hline
\end{tabular}

\begin{tabular}{|c|c|c|}
\hline 2168 & 2169 & 2170 \\
\hline$A 3-1 / \pi 12$ & $A 3-1 / T 13$ & $A 3-1 / T 14$ \\
\hline $12^{*}$ & $12^{\infty}$ & $12^{*}$ \\
\hline
\end{tabular}

\begin{tabular}{|c|c|c|}
\hline 2171 & 2172 & 2173 \\
\hline$A 3-1 / T 15$ & $A 3-1 / \pi 16$ & $A 3-1 / T 17$ \\
\hline $12^{\circ}$ & $12^{\circ}$ & $12^{n}$ \\
\hline
\end{tabular}

DATE OF STANDARDIZATION $\underline{08 / 13 / 98}$

VAIUE OF M $\quad 568$ STANDARDIZATION D 2944

REMARKS: — TEST AREAS WERE DESIGNATED BY CURTIS OBI.

cc:

D. MADSEN BECHTEL
MTL BN FILES 


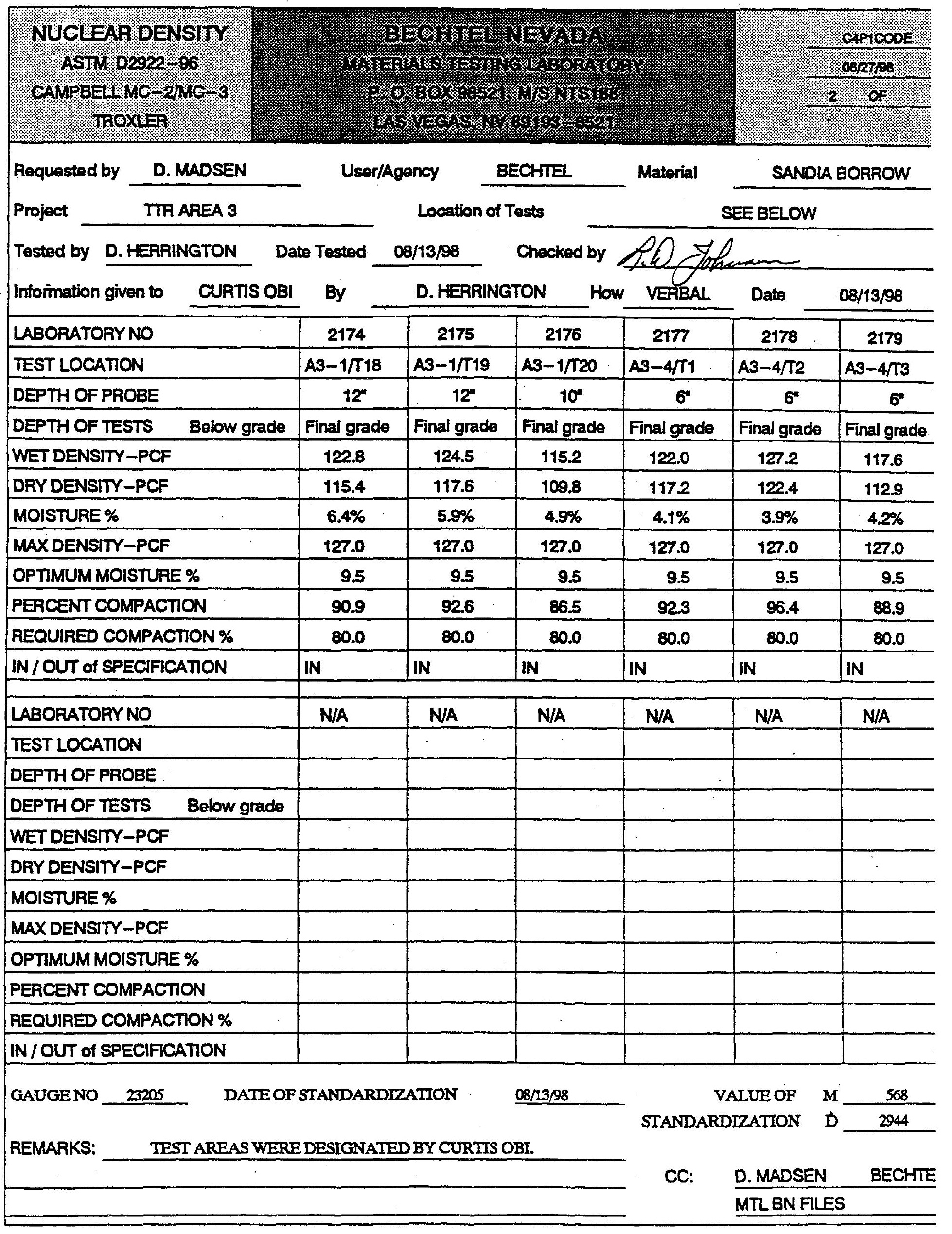




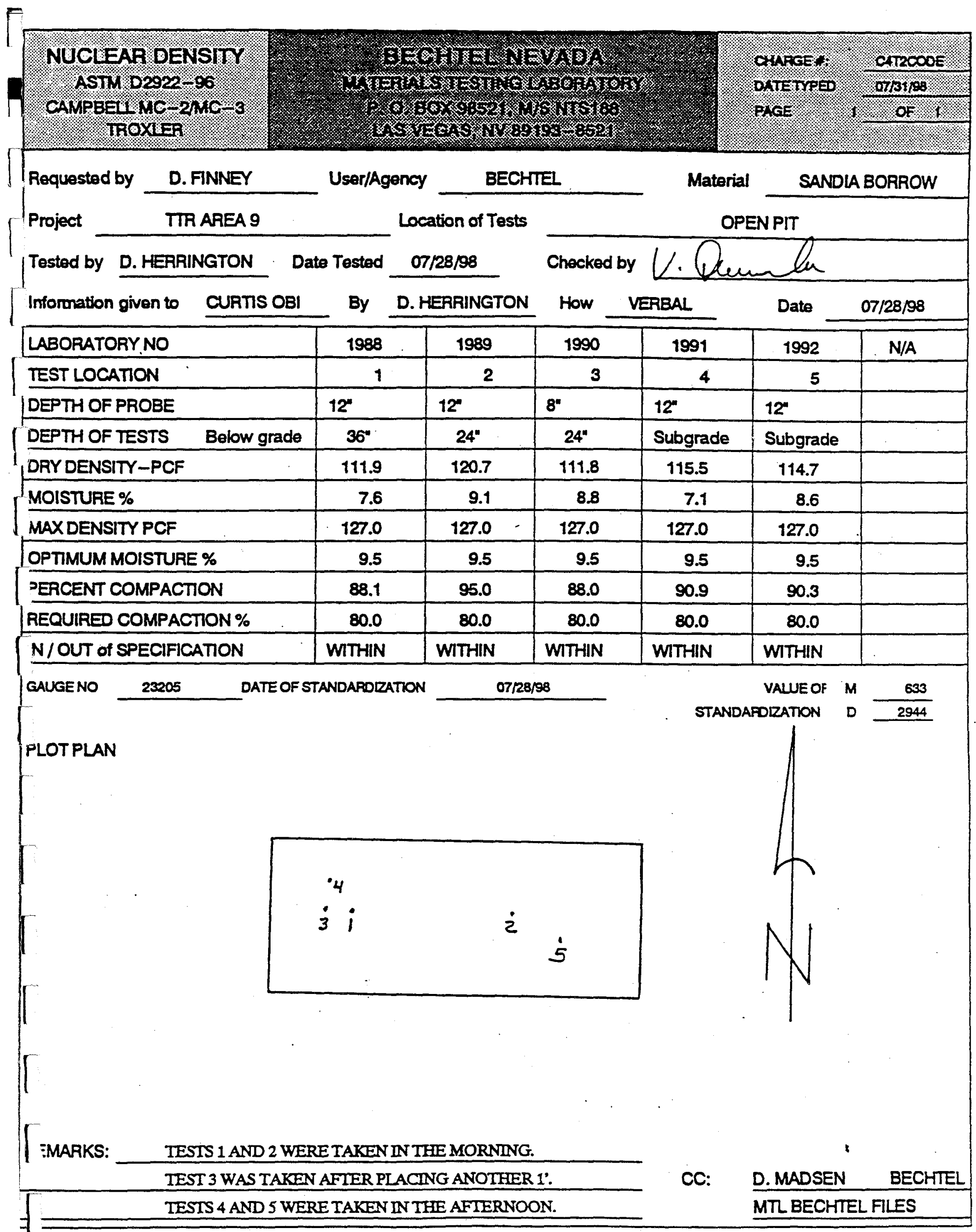




\section{Bechtel Nevada}

\section{Materials Testing Laboratory}

P.O.BOX 98521, M/S NTS 188, LAS VEGAS, NV 89193

(702) 295-6669

\section{Table 1.}

SAMPLE TTR PERMEABILITY TO DI WATER

\section{ASTM D 2434-68 (Reapproved 1974)}

Standard Test Method for Permeability of Granular Soils (Constant Head)

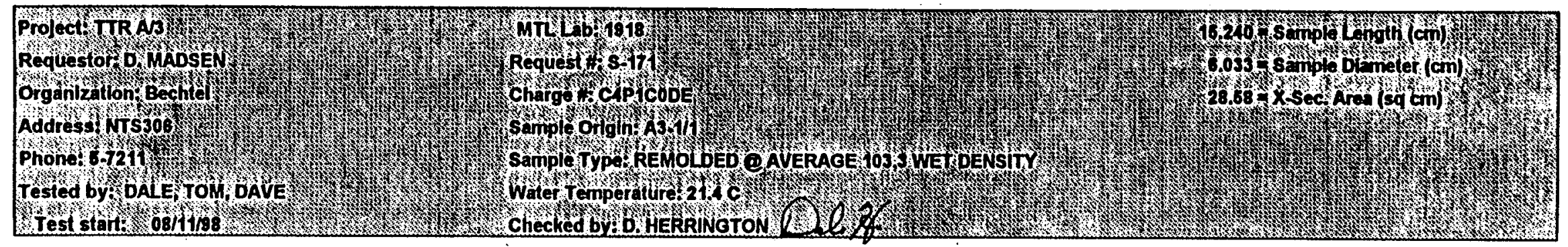

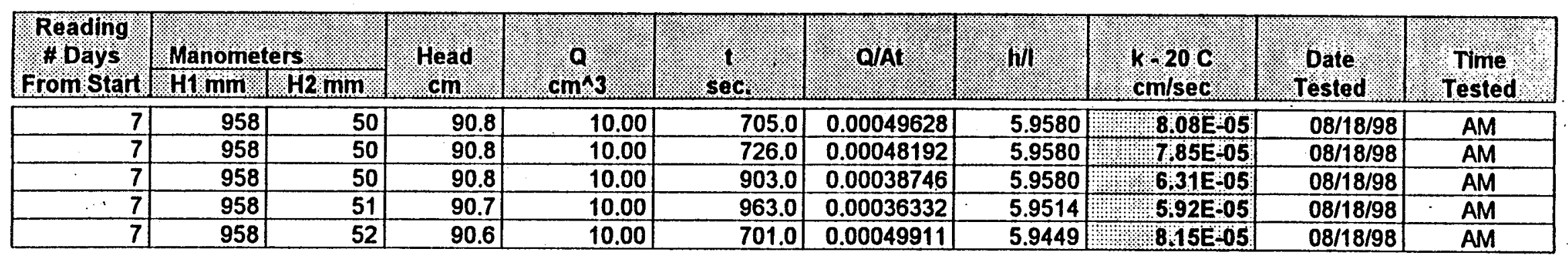




\section{Table 2.}

\section{SAMPLE TTR PERMEABILITY TO DI WATER}

ASTM D 2434-68 (Reapproved 1974)

Standard Test Method for Permeability of Granular Soils (Constant Head)

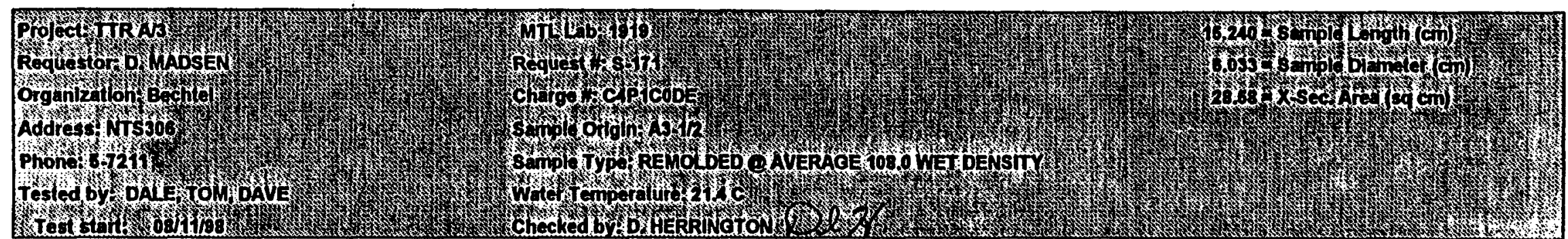

\begin{tabular}{|c|c|c|c|c|c|c|c|c|c|c|}
\hline $\begin{array}{l}\text { Reading } \\
\text { folys } \\
\text { romstart }\end{array}$ & $\begin{array}{l}\text { Manome } \\
\text { H1 } 1 \text { nnm }\end{array}$ & $\frac{13}{12}$ & Head & $\operatorname{cm}^{9} 3$ & 18 & OIAT & Sill & 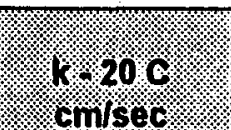 & Datested & Timies \\
\hline 8 & 957 & 58 & 89.9 & 10.00 & 266.0 & 0.00131533 & 5.8990 & $216 E-04$ & $08 / 19 / 98$ & $A M$ \\
\hline 8 & 957 & 58 & 89.9 & 10.00 & 305.0 & 0.00114714 & 5.8990 & $1.89 E=04$ & $08 / 19 / 98$ & $\overline{A M}$ \\
\hline 8 & 957 & 56 & 90.1 & 10.00 & 379.0 & 0.00092316 & 5.9121 & $1.52 \mathrm{E}: 04$ & $08 / 19 / 98$ & $A M$ \\
\hline 8 & 957 & 55 & 90.2 & 10.00 & 342.0 & 0.00102303 & 5.9186 & $1.68 \mathrm{E}-04$ & $08 / 19 / 98$ & $\overline{A M}$ \\
\hline
\end{tabular}




\section{Bechtel Nevada}

\section{Materials Testing Laboratory}

P.O.BOX 98521, MIS NTS 188, LAS VEGAS, NV 89193

(702) 295-6669

\section{Table 3.}

SAMPLE TTR PERMEABILITY TO DI WATER

\section{ASTM D 2434-68 (Reapproved 1974)}

Standard Test Method for Permeability of Granular Soils (Constant Head)

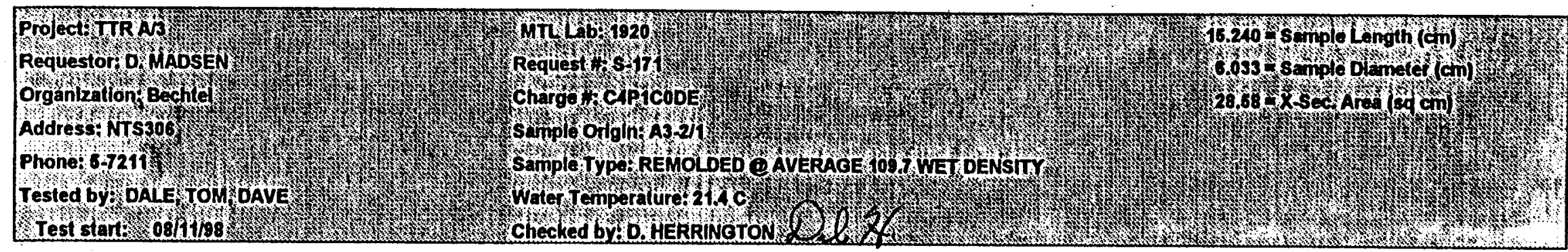

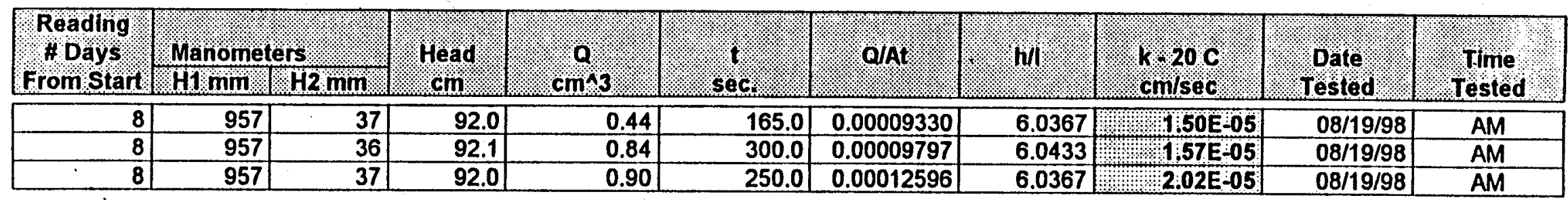




\section{Table 4.}

SAMPLE TTR PERMEABILITY TO DI WATTER

ASTM D 2434-68 (Reapproved 1974)

Standard Test Method for Permeability of Granular Soils (Constant Head)

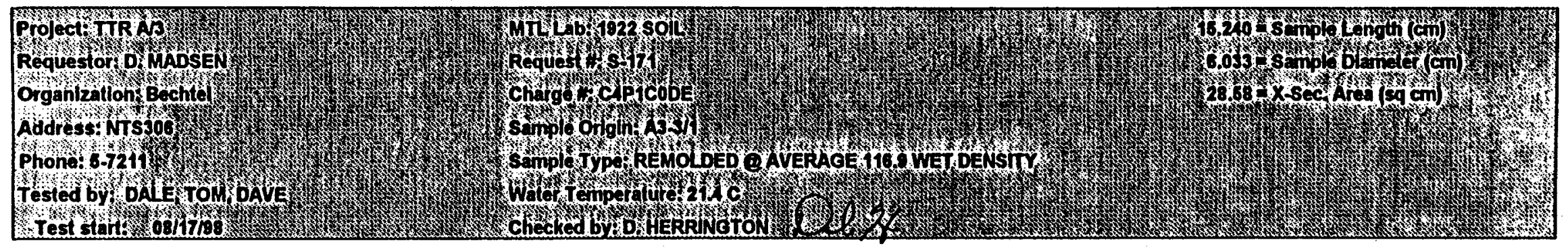

\begin{tabular}{|c|c|c|c|c|c|c|c|c|c|c|}
\hline \multirow{2}{*}{$\begin{array}{l}\text { Reading } \\
\text { Y Days } \\
\text { Eromstart }\end{array}$} & \multicolumn{2}{|c|}{ Manometers } & \multirow{2}{*}{ Head } & \multirow{2}{*}{$\frac{0}{\operatorname{cm} \times 3}$} & \multirow{2}{*}{ : } & \multirow[t]{2}{*}{ OAP. } & \multirow[t]{2}{*}{ Will } & \multirow{2}{*}{ cmisec. } & \multirow{2}{*}{ Date } & \multirow{2}{*}{ Timie } \\
\hline & H1 num & H2 nnin & & & & & & & & \\
\hline 7 & 953 & 60 & 89.3 & 10.00 & 137.0 & 0.00255385 & 5.8596 & $1 \% 423 E 04$ & $08 / 18 / 98$ & AM \\
\hline 7 & 953 & 53 & 90.0 & 10.00 & 98.0 & 0.00357017 & 5.9055 & 587E-04 & $08 / 18 / 98$ & AM \\
\hline 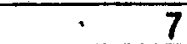 & $\overline{953}$ & 54 & 89.9 & 10.00 & 78.0 & 0.00448560 & 5.8990 & $7: 38 E=04$ & $08 / 18 / 98$ & AM \\
\hline 17 & 953 & 56 & 89.7 & 10.00 & 70.0 & 0.00499824 & 5.8858 & 8.24E:04 & $08 / 18 / 98$ & $\overline{A M}$ \\
\hline 7 & 953 & 57 & 89.6 & 10.00 & 59.0 & 0.00593012 & 5.8793 & $\% \% 9: 79 E=4$ & $08 / 18 / 98$ & AM \\
\hline$\overline{7}$ & 953 & 57 & 89.6 & 10.00 & 64.0 & 0.00546683 & 5.8793 & 9.02E04 & $08 / 18 / 98$ & AM \\
\hline
\end{tabular}




\section{Bechtel Nevada}

Materials Testing Laboratory

P.O.BOX 98521, M/S NTS 188, LAS VEGAS, NV 89193

(702) 295-6669

\section{Table 5.}

SAMPLE TTR PERMEABILITY TO DI WATER

ASTM D 2434-68 (Reapproved 1974)

Standard Test Method for Permeability of Granular Soils (Constant Head)

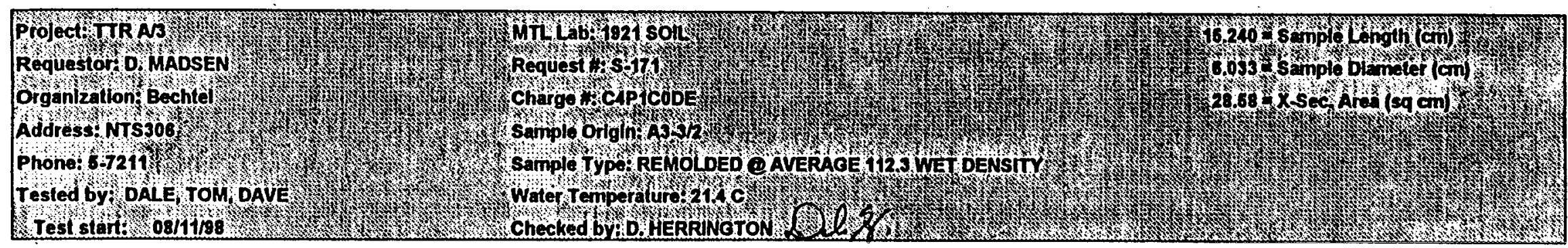

\begin{tabular}{|c|c|c|c|c|c|c|c|c|c|c|}
\hline \multirow{2}{*}{$\begin{array}{l}\text { Reading } \\
\text { \# Days } \\
\text { rom stant }\end{array}$} & \multicolumn{2}{|c|}{ Manometers } & \multirow{2}{*}{ Head } & \multirow{2}{*}{$\begin{array}{c}\mathrm{a}^{2} \\
\mathrm{~cm} \mathrm{n}_{3}\end{array}$} & \multirow{2}{*}{$\begin{array}{l}\text { t? } \\
\mathrm{sec}\end{array}$} & \multirow[t]{2}{*}{ QIAL } & \multirow[t]{2}{*}{ hill } & \multirow{2}{*}{$\begin{array}{l}200 \\
\mathrm{~cm} \text { ins } \mathrm{sec}\end{array}$} & \multirow{2}{*}{$\begin{array}{l}\text { Date } \\
\text { rested }\end{array}$} & \multirow{2}{*}{$\begin{array}{l}\text { trimes } \\
\text { Tested }\end{array}$} \\
\hline & $\mathrm{HImin}$ & $\mathrm{H} 2 \mathrm{~mm}$ & & & & & & & & \\
\hline 8 & 972 & 37 & 93.5 & 0.67 & 420.0 & 0.00005581 & 6.1352 & $08.83 E-06$ & $08 / 19 / 98$ & AM \\
\hline 8 & 972 & 37 & 93.5 & 0.47 & 330.0 & 0.00004983 & 6.1352 & $0 \quad 7.88 \mathrm{E}-06$ & $08 / 19 / 98$ & AM \\
\hline 8 & 971 & 35 & 93.6 & 0.72 & 840.0 & 0.00002999 & 6.1417 & $4.74 E-06$ & $08 / 19 / 98$ & $\overline{A M}$ \\
\hline 8 & 971 & 36 & 93.5 & 0.60 & 545.0 & 0.00003852 & 6.1352 & 6 6:09E-06 & $08 / 19 / 98$ & AM \\
\hline
\end{tabular}


VIateriars Testing Laboratory

P.O.BOX 98521, M/S NTS 188, LAS VEGAS, NV 89193

(702) 295-6669

\section{Table 6.}

SAMPLE TTR PERMEABILITY TO DI WATER

ASTM D 2434-68 (Reapproved 1974)

Standard Test Method for Permeability of Granular Solls (Constant Head)

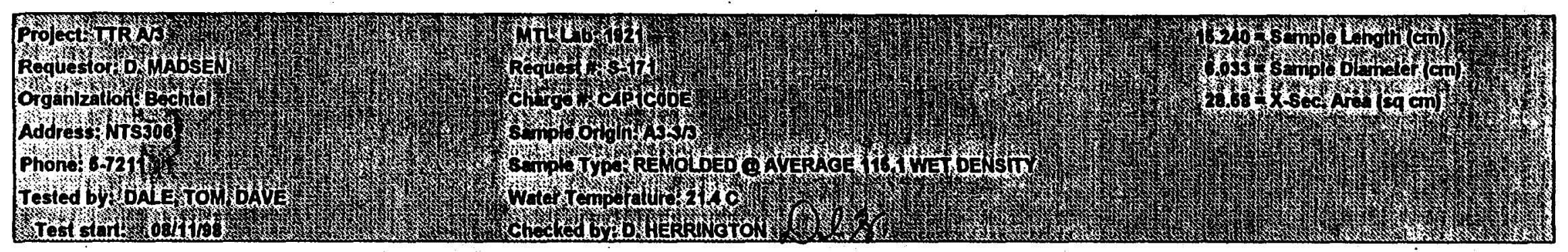

\begin{tabular}{|c|c|c|c|c|c|c|c|c|c|c|}
\hline $\begin{array}{l}\text { Reading } \\
\text { \# bays } \\
\text { eromstart }\end{array}$ & \multicolumn{2}{|c|}{ Manometers } & rear & $\cos ^{0}$ & sec & Q/A & hill & $\begin{array}{l}4200 \\
\operatorname{con} 15.0\end{array}$ & Daterted & Trime \\
\hline 8 & 792 & 38 & 75.4 & 0.18 & 149.0 & 0.00004227 & 4.9475 & 8.29E\%06 & $08 / 19 / 98$ & $\overline{A M}$ \\
\hline 8 & 971 & 36 & 93.5 & 0.59 & 702.0 & 0.00002941 & 6.1352 & $4,65 E \div 06$ & $08 / 19 / 98$ & $\overline{A M}$ \\
\hline .8 & 971 & 35 & 93.6 & 0.44 & 493.0 & 0.00003123 & 6.1417 & $4.93 \mathrm{E}: 06$ & $08 / 19 / 98$ & $A M$ \\
\hline
\end{tabular}




\section{Bechtel Nevada}

\section{Materials Testing Laboratory}

P.O.BOX 98521, M/S NTS 188, LAS VEGAS, NV 89193

(702) 295-6669

\section{Table 7.}

SAMPLE TTR PERMEABILITY TO DI WATER

ASTM D 2434-68 (Reapproved 1974)

Standard Test Method for Permeability of Granular Solls (Constant Head)

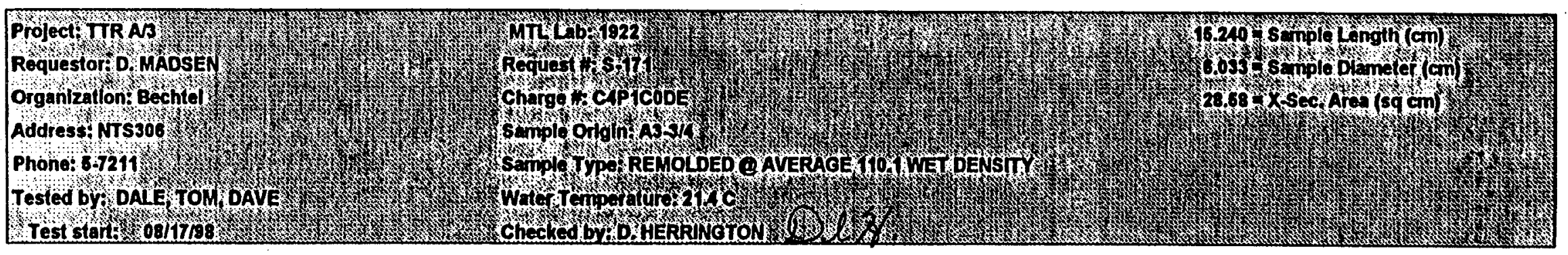

\begin{tabular}{|c|c|c|c|c|c|c|c|c|c|c|}
\hline \multirow{2}{*}{$\begin{array}{l}\text { Reading } \\
\text { \# Days } \\
\text { From start }\end{array}$} & \multicolumn{2}{|c|}{ Manomelers } & \multirow{2}{*}{ Head } & \multirow{2}{*}{ coms } & \multirow{2}{*}{$8 \%$} & \multirow[t]{2}{*}{ QIAt } & \multirow[t]{2}{*}{ 6il } & \multirow{2}{*}{ chinsog. } & \multirow{2}{*}{$\begin{array}{l}\text { Daso } \\
\text { Iestod }\end{array}$} & \multirow{2}{*}{ \%onge } \\
\hline & $\mathrm{H1} \mathrm{mm}$ & H2min & & & & & & & & \\
\hline 7 & 996 & 53 & 94.3 & 10.00 & 15.0 & 0.02332514 & 6.1877 & $366 \mathrm{E} 003$ & $08 / 18 / 98$ & $\mathrm{AM}$ \\
\hline 7 & 996 & 53 & 94.3 & 10.00 & 15.0 & 0.02332514 & 6.1877 & 366 E-03 & $08 / 18 / 98$ & AM \\
\hline 7 & 996 & 53 & 94.3 & 10.00 & 16.0 & 0.02186732 & 6.1877 & (3) $43 E-03$ & $08 / 18 / 98$ & $\overline{A M}$ \\
\hline 7 & 996 & 53 & 94.3 & 10.00 & 16.0 & 0.02186732 & 6.1877 & (K) $3.43 E 003$ & $08 / 18 / 98$ & AM \\
\hline 7 & 996 & 53 & 94.3 & 10.00 & 16.0 & 0.02186732 & 6.1877 & $0.3 .43 E=03$ & $08 / 18 / 98$ & $\overline{A M}$ \\
\hline
\end{tabular}




\section{Table 8.}

SAMPLE TTR PERMEABILITY TO DI WATER

\section{ASTM D 2434-68 (Reapproved 1974)}

Standard Test Method for Permeability of Granular Solls (Constant Head)

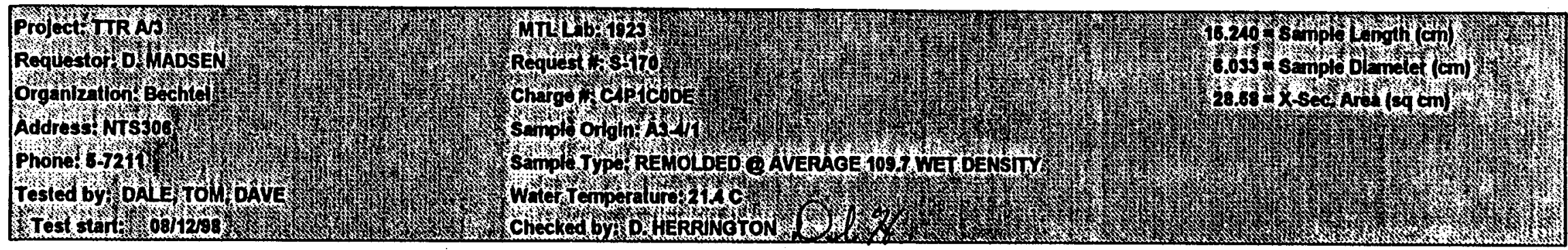

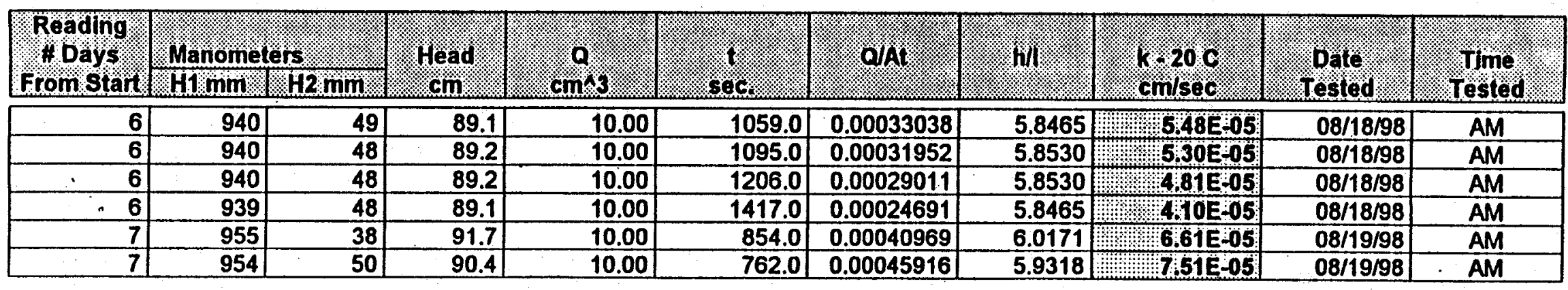




\section{Bechtel Nevada}

\section{Materials Testing Laboratory}

P.O.BOX 98521, M/S NTS 188, LAS VEGAS, NV 89193

(702) 295-6669

\section{Table 9.}

SAMPLE TTR PERMEABILITY TO DI WATER

ASTM D 2434-6B (Reapproved 1974)

Standard Test Method for Permeability of Granular Soils (Constant Head)

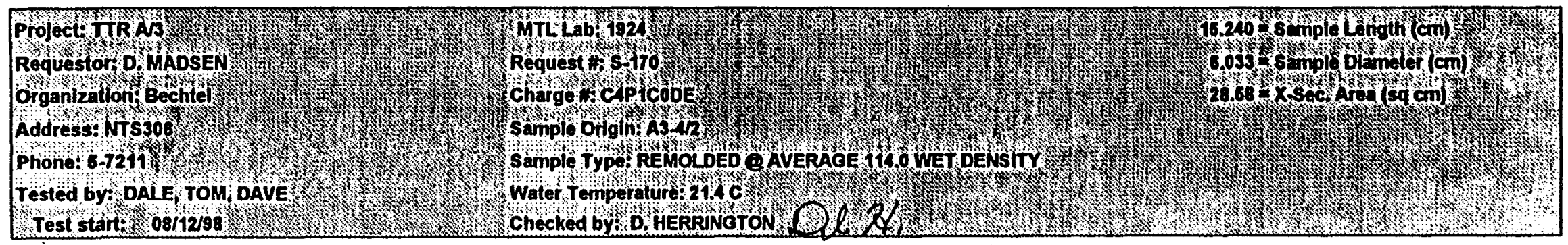

\begin{tabular}{|c|c|c|c|c|c|c|c|c|c|c|}
\hline $\begin{array}{l}\text { Reading } \\
\text { \# Dayss } \\
\text { From Start }\end{array}$ & \multicolumn{2}{|c|}{ Manometers } & Head & $\mathrm{cm}^{\mathrm{a}} 3$. & sece. & QIAT: & hill: & $\begin{array}{l}1 \\
\mathrm{~cm} / \mathrm{sec}\end{array}$ & Date & $\begin{array}{c}\text { Time } \\
\text { Tested }\end{array}$ \\
\hline 1 & 881 & 49 & 83.2 & 10.00 & 205.0 & 0.00170672 & 5.4593 & $3.03 E 04$ & $08 / 13 / 98$ & $\overline{A M}$ \\
\hline 1 & 880 & 51 & 82.9 & 10.00 & 204.0 & 0.00171508 & 5.4396 & $3.06 \mathrm{E}-04$ & $08 / 13 / 98$ & $A M$ \\
\hline 1 & 880 & 51 & 82.9 & 10.00 & 208.0 & 0.00168210 & 5.4396 & $3.00 \mathrm{E} \div 04$ & $08 / 13 / 98$ & $A M$ \\
\hline 1 & 879 & 48 & 83.1 & 10.00 & 218.0 & 0.00160494 & 5.4528 & $2.86 E-04$ & $08 / 13 / 98$ & AM \\
\hline
\end{tabular}




\section{Table 10.}

SAMPLE TTR PERMEABILITY TO DI WATER

ASTM D 2434-68 (Reapproved 1974)

Standard Test Method for Permeability of Granular Soils (Constant Head)

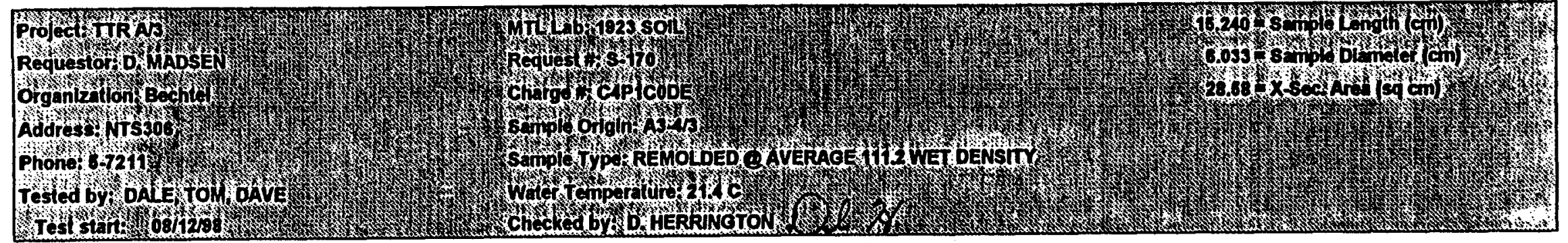

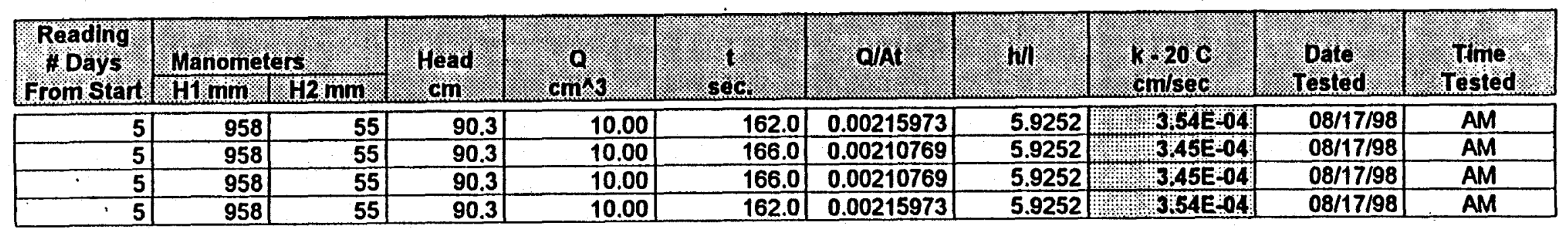




\section{Bechtel Nevada}

\section{Materials Testing Laboratory}

P.O.BOX 98521, M/S NTS 188, LAS VEGAS, NV 89193

(702) 295-6669

\section{Table 11.}

SAMPLE TTR PERMEABILITY TO DI WATER

ASTM D 2434-68 (Reapproved 1974)

Standard Test Method for Permeability of Granular Soils (Constant Head)

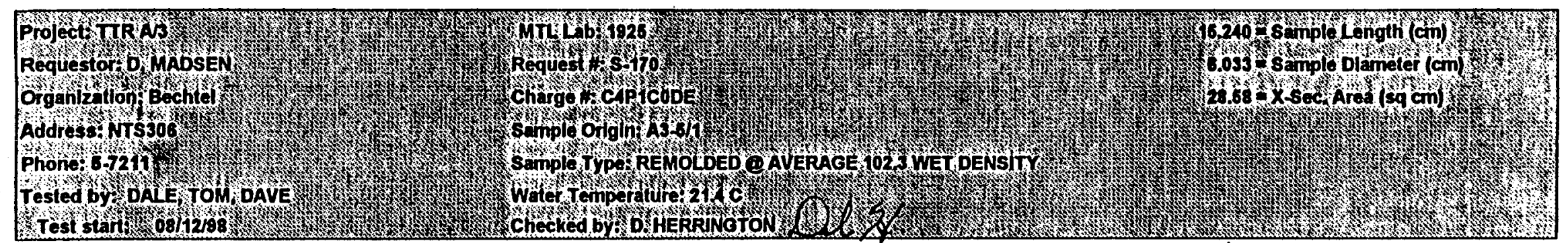

\begin{tabular}{|c|c|c|c|c|c|c|c|c|c|c|}
\hline $\begin{array}{l}\text { Reading } \\
\text { H Days } \\
\text { From Start }\end{array}$ & \multicolumn{2}{|c|}{ Mariometers } & Head & $\begin{array}{c}0 \\
\operatorname{cm}{ }^{3} \\
\end{array}$ & sect. & QIAT: & hill & crisec & Tate & Tíme \\
\hline 1 & 977 & 52 & 92.5 & 10.00 & 539.0 & 0.00064912 & 6.0696 & $104 E-04$ & $08 / 13 / 98$ & $\overline{A M}$ \\
\hline 1 & 977 & 52 & 92.5 & 10.00 & 536.0 & 0.00065276 & 6.0696 & $104 \mathrm{E04}$ & $08 / 13 / 98$ & $A M$ \\
\hline
\end{tabular}


viraterfars TeSung Laworácoiy

P.O.BOX 98521, M/S NTS 188, LAS VEGAS, NV 89193

(702) 295-6669

\section{Table 12.}

SAMPLE TTR PERMEABILITY TO DI WATER

\section{ASTM D 2434-68 (Reapproved 1974)}

Standard Test Method for Permeability of Granular Soils (Constant Head)

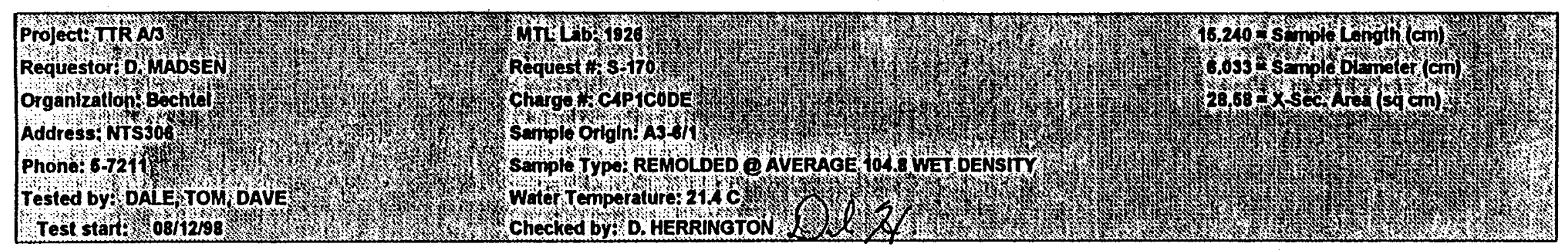

\begin{tabular}{|c|c|c|c|c|c|c|c|c|c|c|}
\hline \multirow{2}{*}{$\begin{array}{l}\text { Reading. } \\
\text { \# Days } \\
\text { From Start }\end{array}$} & \multicolumn{2}{|c|}{ Manometers } & \multirow{2}{*}{$\begin{array}{c}\text { Head } \\
\mathrm{cm}\end{array}$} & \multirow{2}{*}{$\mathrm{cm}^{0} \mathbf{3}$} & \multirow{2}{*}{$\sqrt{1}$ sec. } & \multirow[t]{2}{*}{ QIAI } & \multirow[t]{2}{*}{ hill } & \multirow{2}{*}{$\mathrm{cm} / \mathrm{sec} \mathrm{C}$} & \multirow{2}{*}{$\begin{array}{l}\text { Date } \\
\text { Tested }\end{array}$} & \multirow{2}{*}{$\begin{array}{l}\text { Time } \\
\text { Tested }\end{array}$} \\
\hline & $\mathrm{HL} \mathrm{mm}$ & $\mathrm{H} 2 \mathrm{~mm}$ & & & & & & & & \\
\hline 0 & 976 & 36 & 94.0 & 10.00 & 18.0 & 0.01943761 & 6.1680 & $3.06 \mathrm{E}-03$ & $08 / 12 / 98$ & $\overline{A M}$ \\
\hline 0 & 976 & 36 & 94.0 & 10.00 & 18.0 & 0.01943761 & 6.1680 & $3: 06 E-03$ & $08 / 12 / 98$ & AM \\
\hline 0 & 976 & 36 & 94.0 & 10.00 & 18.0 & 0.01943761 & 6.1680 & $\because \quad 3.06 E-03$ & $08 / 12 / 98$ & AM \\
\hline 0 & 976 & 36 & 94.0 & 10.00 & 18.0 & 0.01943761 & 6.1680 & $3.06 \mathrm{E}-03$ & $08 / 12 / 98$ & AM \\
\hline
\end{tabular}


Bechtel Nevada

Materials Testing Laboratory

P.O.BOX 98521, M/S NTS 188, LAS VEGAS, NV 89193

(702) 295-6669

Table 13.

SAMPLE TTR PERMEABILITY TO DI WATER

ASTM D 2434-68 (Reapproved 1974)

Standard Test Method for Permeability of Granular Solls (Constant Head)

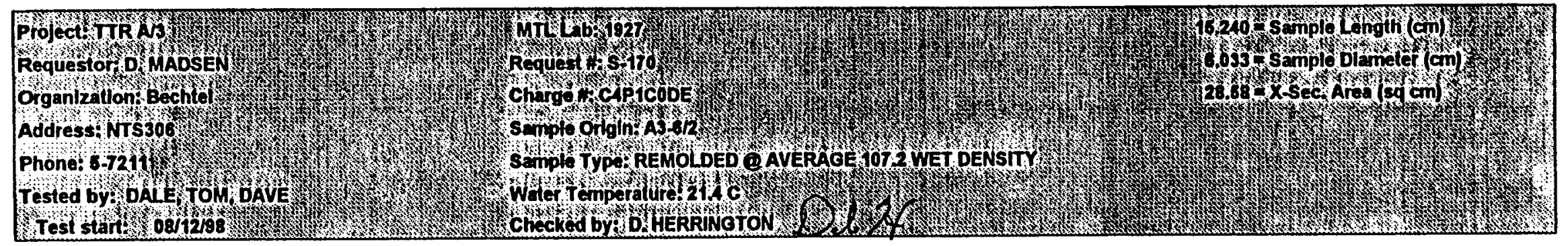

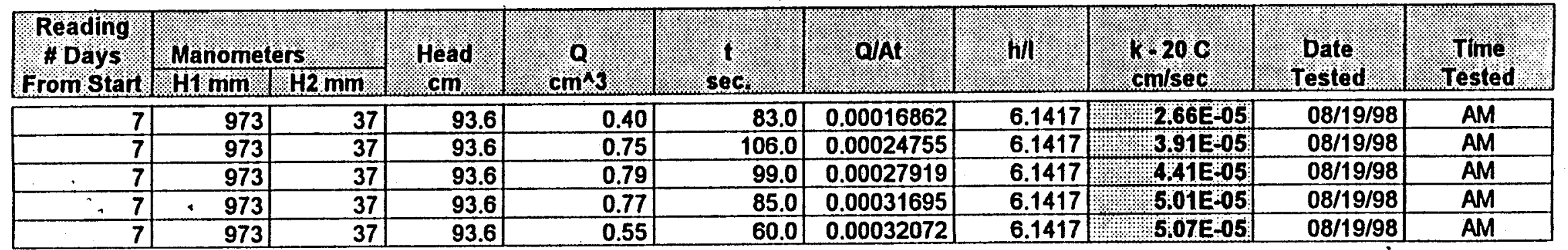


Materials Testing Laboratory

I I

1

P.O.BOX 98521, M/S NTS 188, LAS VEGAS, NV 89193

(702) 295-6669

Table 14.

SAMPLE TTR PERMEABILITY TO DI WATER

ASTM D 2434-68 (Reapproved 1974)

Standard Test Method for Permeability of Granular Soils (Constant Head)

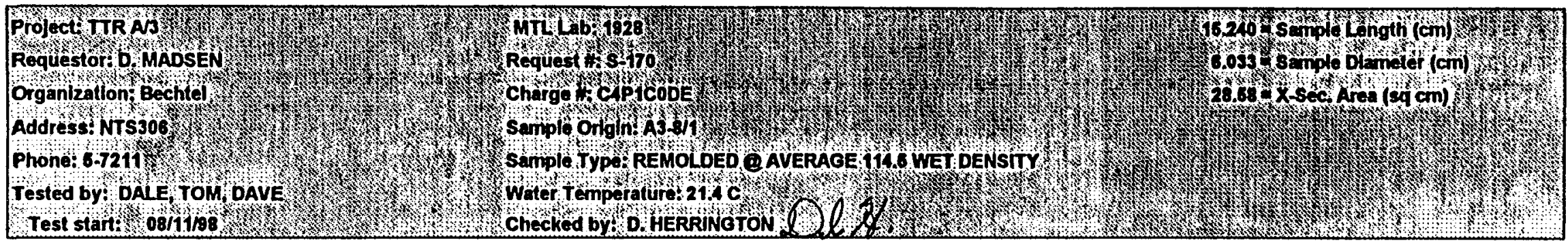

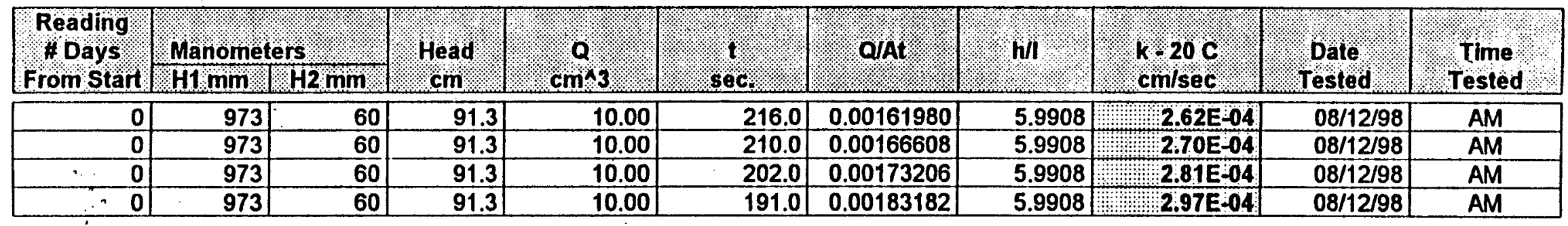




\section{Bechtel Nevada}

\section{Materials Testing Laboratory}

P.O.BOX 98521, M/S NTS 188, LAS VEGAS, NV 89193

(702) 295-6669

\section{Table 15.}

SAMPLE TTR PERMEABILITY TO DI WATER

\section{ASTM D 2434-68 (Reapproved 1974)}

Standard Test Method for Permeability of Granular Soils (Constant Head)

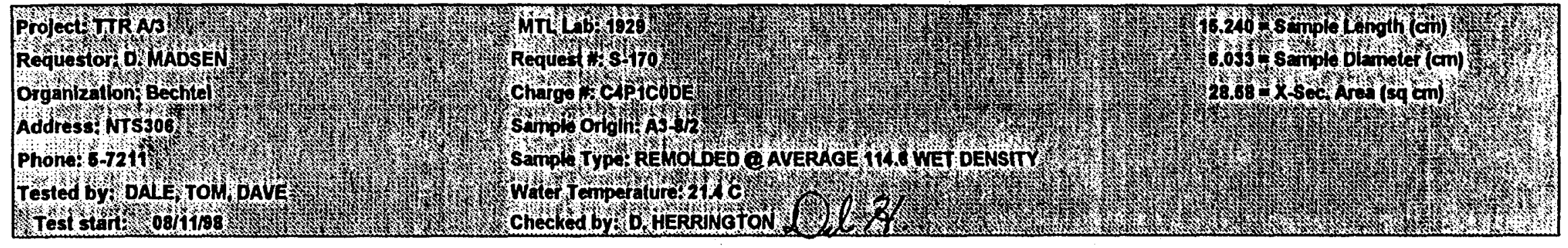

\begin{tabular}{|c|c|c|c|c|c|c|c|c|c|c|}
\hline \multirow{2}{*}{$\begin{array}{l}\text { Roading } \\
\text { \# Days } \\
\text { From stant }\end{array}$} & \multicolumn{2}{|c|}{ Manometers } & \multirow{2}{*}{ Head } & \multirow{2}{*}{$\mathrm{com}^{\mathrm{cm}} \mathrm{s}$} & \multirow{2}{*}{ 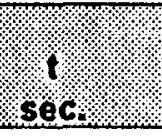 } & \multirow[t]{2}{*}{ Q/A) } & \multirow[t]{2}{*}{ iil } & \multirow{2}{*}{$\begin{array}{l}\mathrm{k} 20 \mathrm{O} \\
\mathrm{cm} / \mathrm{sec}\end{array}$} & \multirow{2}{*}{$\begin{array}{l}\text { pate } \\
\text { rested }\end{array}$} & \multirow{2}{*}{$\begin{array}{l}\text { Thine. } \\
\text { Tested }\end{array}$} \\
\hline & $\mathrm{HI} \mathrm{mm}$ & H2 mm & & & & & & & & \\
\hline 6 & 940 & 55 & 88.5 & 10.00 & 665.0 & 0.00052613 & 5.8071 & 8.79E्S & $08 / 18 / 98$ & $\overline{A M}$ \\
\hline 6 & 940 & 54 & 88.6 & 10.00 & 679.0 & 0.00051528 & 5.8136 & 8.60E-05 & $08 / 18 / 98$ & AM \\
\hline 6 & 940 & 54 & 88.6 & 10.00 & 670.0 & 0.00052220 & 5.8136 & $8.72 \mathrm{E}-05$ & $08 / 18 / 98$ & $A M$ \\
\hline$\because 6$ & 940 & 54 & 88.6 & 10.00 & 590.0 & 0.00059301 & 5.8136 & $9: 90 \mathrm{E} 05$ & $08 / 18 / 98$ & $A M$ \\
\hline 6 & 940 & 55 & 88.5 & 10.00 & 497.0 & 0.00070398 & 5.8071 & O18E-04 & $08 / 18 / 98$ & AM \\
\hline 6 & 939 & 56 & 88.3 & 10.00 & 440.0 & 0.00079518 & 5.7940 & $133 \mathrm{E}=04$ & $08 / 18 / 98$ & AM \\
\hline 6 & 939 & 56 & 88.3 & 10.00 & 450.0 & 0.00077750 & 5.7940 & $1,30 \mathrm{E}-04$ & $08 / 18 / 98$ & AM \\
\hline 7 & 955 & 54 & 90.1 & 10.00 & 243.0 & 0.00143982 & 5.9121 & $2,36 E-04$ & $08 / 19 / 98$ & $A M$ \\
\hline 7 & 953 & 56 & 89.7 & 10.00 & 225.0 & 0.00155501 & 5.8858 & $2.56 \mathrm{E}: 04$ & $08 / 19 / 98$ & $\mathrm{AM}$ \\
\hline
\end{tabular}




\section{Materials Testing Laboratory}

P.O.BOX 98521, M/S NTS 188, LAS VEGAS, NV 89193

(702) 295-6669

\section{Table 16.}

SAMPLE TTR PERMEABILITY TO DI WATER

ASTM D 2434-68 (Reapproved 1974)

Standard Test Method for Permeability of Granular Solls (Constant Head)

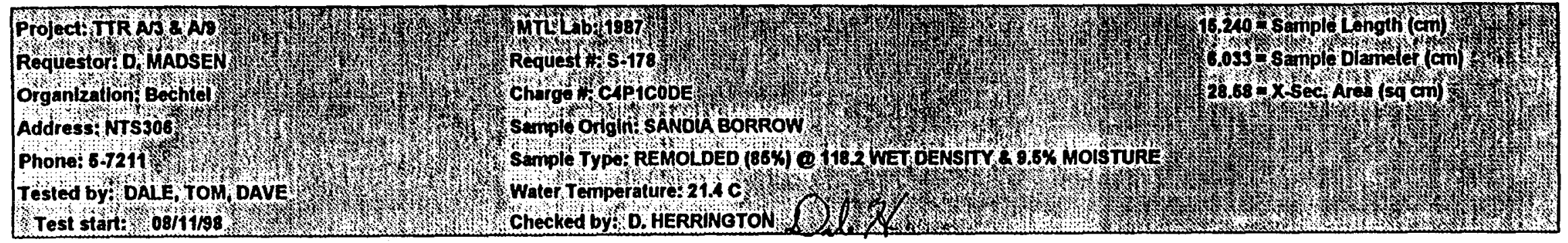

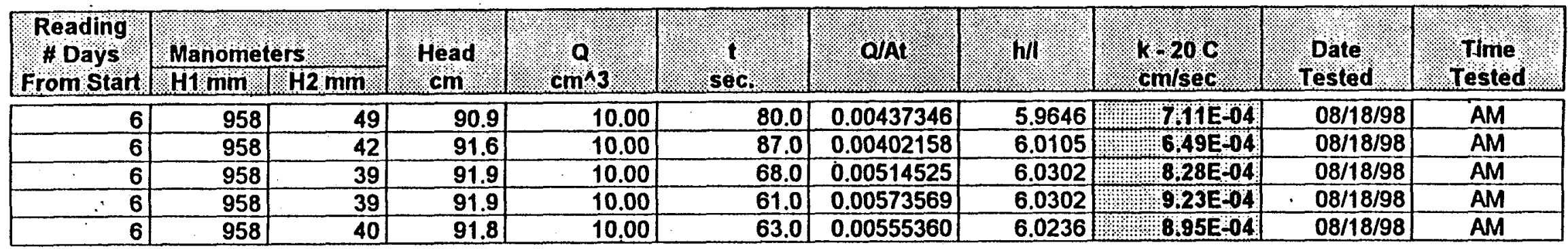




\section{Bechtel Nevada}

\section{Materials Testing Laboratory}

P.O.BOX 98521; M/S NTS 188, LAS VEGAS, NV 89193

(702) 295-6669

\section{Table 17.}

SAMPLE TTR PERMEABILITY TO DI WATER

ASTM D 2434-68 (Reapproved 1974)

Standard Test Method for Permeability of Granular Soils (Constant Head)

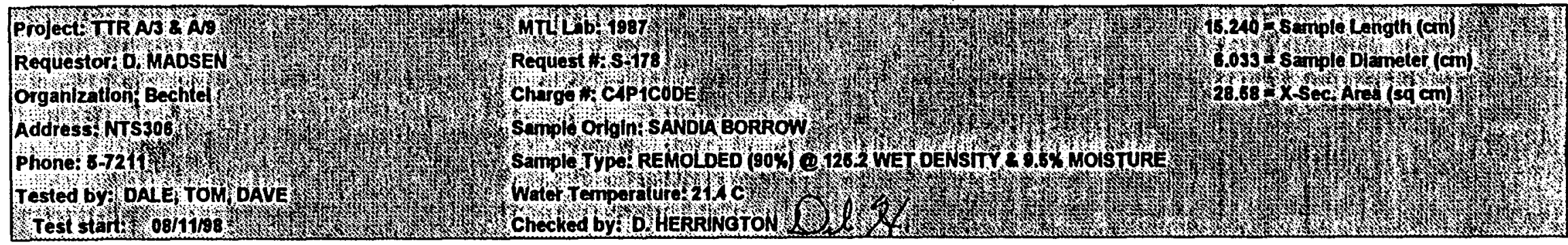

\begin{tabular}{|c|c|c|c|c|c|c|c|c|c|c|}
\hline $\begin{array}{l}\text { Reading } \\
\text { \# Days } \\
\text { From Start }\end{array}$ & \multicolumn{2}{|c|}{ Manometers } & Head & $\operatorname{cm}^{9} 3$ & (1) & QAt & iil & $\begin{array}{l}1.20 \mathrm{c} \\
\mathrm{cm} / \mathrm{sec} .\end{array}$ & $\begin{array}{l}\text { Date } \\
\text { Tested }\end{array}$ & Timested \\
\hline 6 & 957 & 38 & 91.9 & 0.30 & 107.0 & 0.00009810 & 6.0302 & $158 \mathrm{E}-05$ & $08 / 18 / 98$ & $A M$ \\
\hline 6 & 957 & 40 & 91.7 & 0.65 & 105.0 & 0.00021659 & $6 . \overline{0171}$ & $3.49 \mathrm{E}-05$ & $08 / 18 / 98$ & $A M$ \\
\hline 6 & 957 & 40 & 91.7 & 0.90 & 127.0 & 0.00024794 & 6.0171 & 4.00E 05 & $08 / 18 / 98$ & AM \\
\hline 6 & 957 & 42 & 91.5 & 0.85 & 128.0 & 0.00023234 & 6.0039 & $3.75 \mathrm{E}-05$ & $08 / 18 / 98$ & $A M$ \\
\hline 6 & 957 & 40 & 91.7 & 0.78 & 121.0 & 0.00022554 & 6.0171 & $3.64 E-05$ & $08 / 18 / 98$ & $A M$ \\
\hline
\end{tabular}




\section{[ inte leve}

\section{Materials Testing Laboratory}

P.O.BOX 98521, M/S NTS 188, LAS VEGAS, NV 89193

(702) 295-6669

\section{Table 18.}

SAMPLE TTR PERMEABILITY TO DI WATER

\section{ASTM D 2434-68 (Reapproved 1974)}

Standard Test Method for Permeability of Granular Solls (Constant Head)

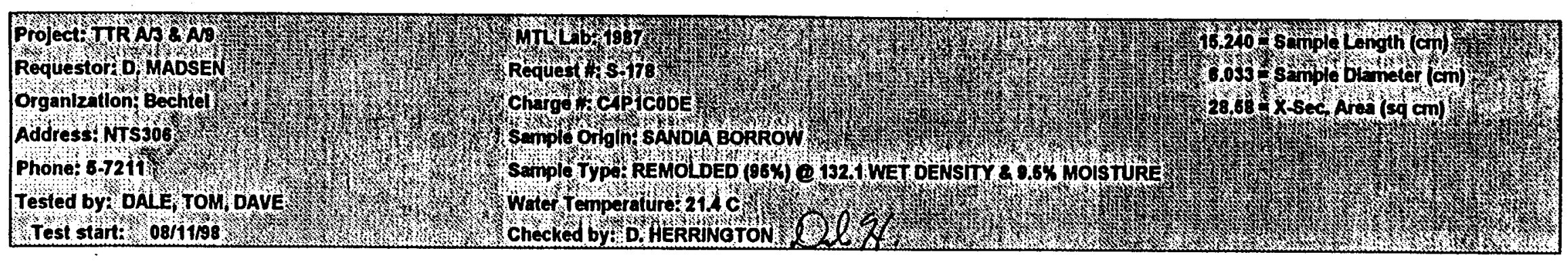

\begin{tabular}{|c|c|c|c|c|c|c|c|c|c|c|}
\hline \multirow{2}{*}{$\begin{array}{l}\text { Reading } \\
\text { \# Days } \\
\text { From Stant }\end{array}$} & \multicolumn{2}{|c|}{ Manometers } & \multirow{2}{*}{$\begin{array}{l}\text { Head } \\
\text { cm }\end{array}$} & \multirow{2}{*}{$\operatorname{com}_{3}$} & \multirow{2}{*}{$\begin{array}{r}\text { t? } \\
\text { sec }\end{array}$} & \multirow[t]{2}{*}{ QIAt } & \multirow[t]{2}{*}{ hil } & \multirow{2}{*}{$\begin{array}{l}\mathrm{k} \\
\mathrm{cm} / \mathrm{m} / \mathrm{sec}\end{array}$} & \multirow{2}{*}{$\begin{array}{l}\text { Date } \\
\text { Tested }\end{array}$} & \multirow{2}{*}{$\begin{array}{l}\text { Tested } \\
\text { Teste }\end{array}$} \\
\hline & $\mathrm{H1mm}$ & $\mathrm{H} 2 \mathrm{~mm}$ & & & & & & & & \\
\hline 6 & 957 & 36 & 92.1 & 0.72 & 370.0 & 0.00006808 & 6.0433 & $1.09 E-05$ & $08 / 18 / 98$ & $\overline{A M}$ \\
\hline 6 & 957 & 40 & 91.7 & 0.40 & 68.0 & 0.00020581 & 6.0171 & $332 E-05$ & $08 / 18 / 98$ & AM \\
\hline 6 & 957 & 40 & 91.7 & 1.11 & 199.0 & 0.00019516 & 6.0171 & 3) 3,15E-05 & $08 / 18 / 98$ & AM \\
\hline$\therefore 6$ & 955 & 38 & 91.7 & 0.70 & 473.0 & 0.00005178 & 6.0171 & 0.35E-06 & $08 / 18 / 98$ & AM \\
\hline 6 & 955 & 36 & 91.9 & 0.95 & 678.0 & 0.00004902 & 6.0302 & O४ 7,89E-06 & $08 / 18 / 98$ & AM \\
\hline 6 & 955 & 40 & 91.5 & 0.70 & 373.0 & 0.00006566 & 6.0039 & 1.06E-05 & $08 / 18 / 98$ & $A M$ \\
\hline 6 & 954 & 37 & 91.7 & 0.74 & 330.0 & 0.00007846 & 6.0171 & F 1,27E-05 & $08 / 18 / 98$ & $A M$ \\
\hline 6 & 954 & 37 & 91.7 & 0.50 & 357.0 & 0.00004900 & 6.0171 & POF7:90E:06 & $08 / 18 / 98$ & AM \\
\hline 6 & 953 & 38 & 91.5 & 0.67 & 484.0 & 0.00004843 & 6.0039 & OY7,83E-06 & $08 / 18 / 98$ & $A M$ \\
\hline 6 & 953 & 38 & 91.5 & 0.48 & 196.0 & 0.00008568 & 6.0039 & (38E05 & $08 / 18 / 98$ & $A M$ \\
\hline 6 & 953 & 38 & 91.5 & 0.63 & 243.0 & 0.00009071 & 6.0039 & $1 \quad 1447 E_{05}$ & $08 / 18 / 98$ & AM \\
\hline 6 & 953 & 38 & 91.5 & 1.00 & 428.0 & 0.00008175 & 6.0039 & $1: 32 \mathrm{E}-05$ & $08 / 18 / 98$ & $A M$ \\
\hline
\end{tabular}




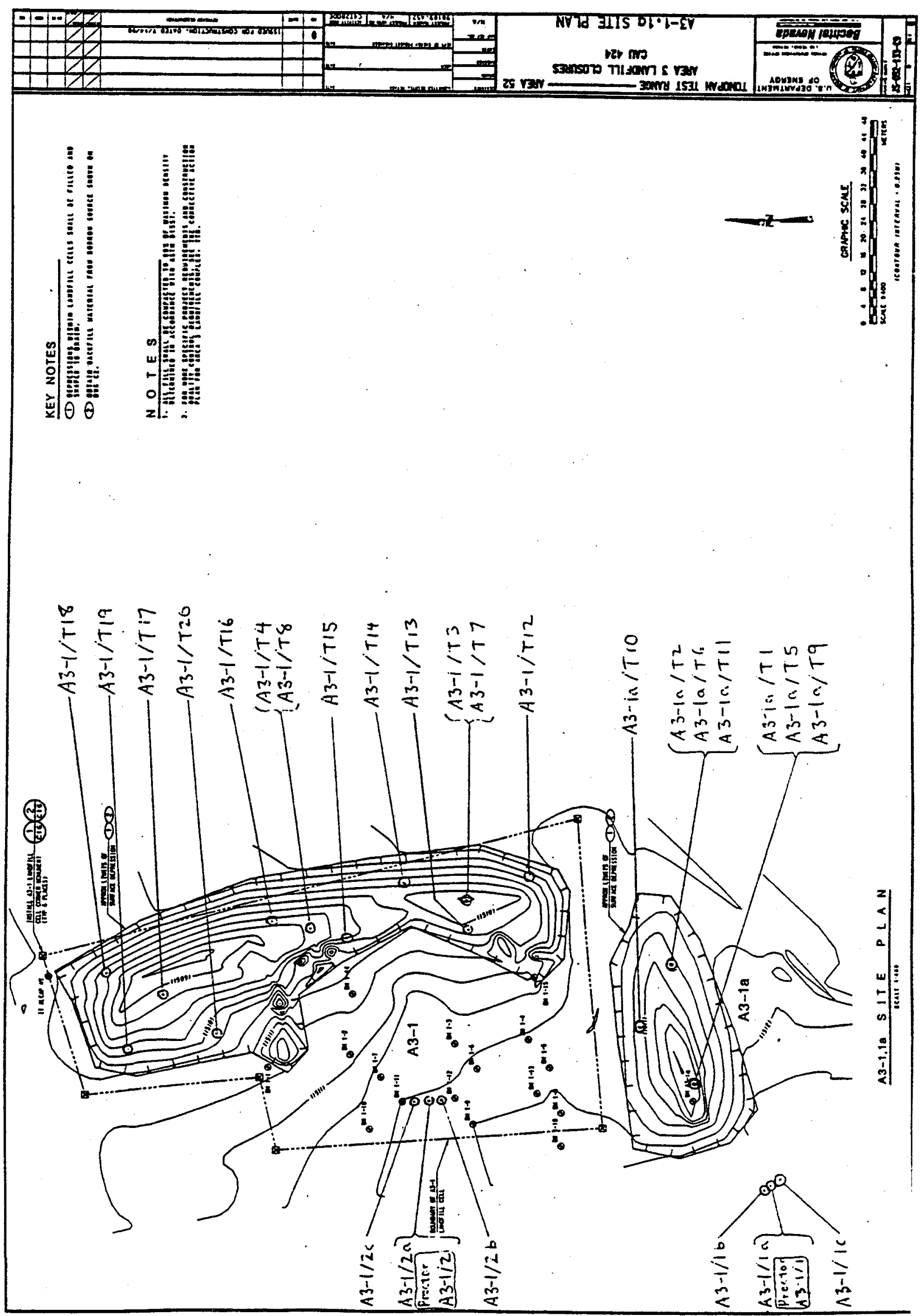




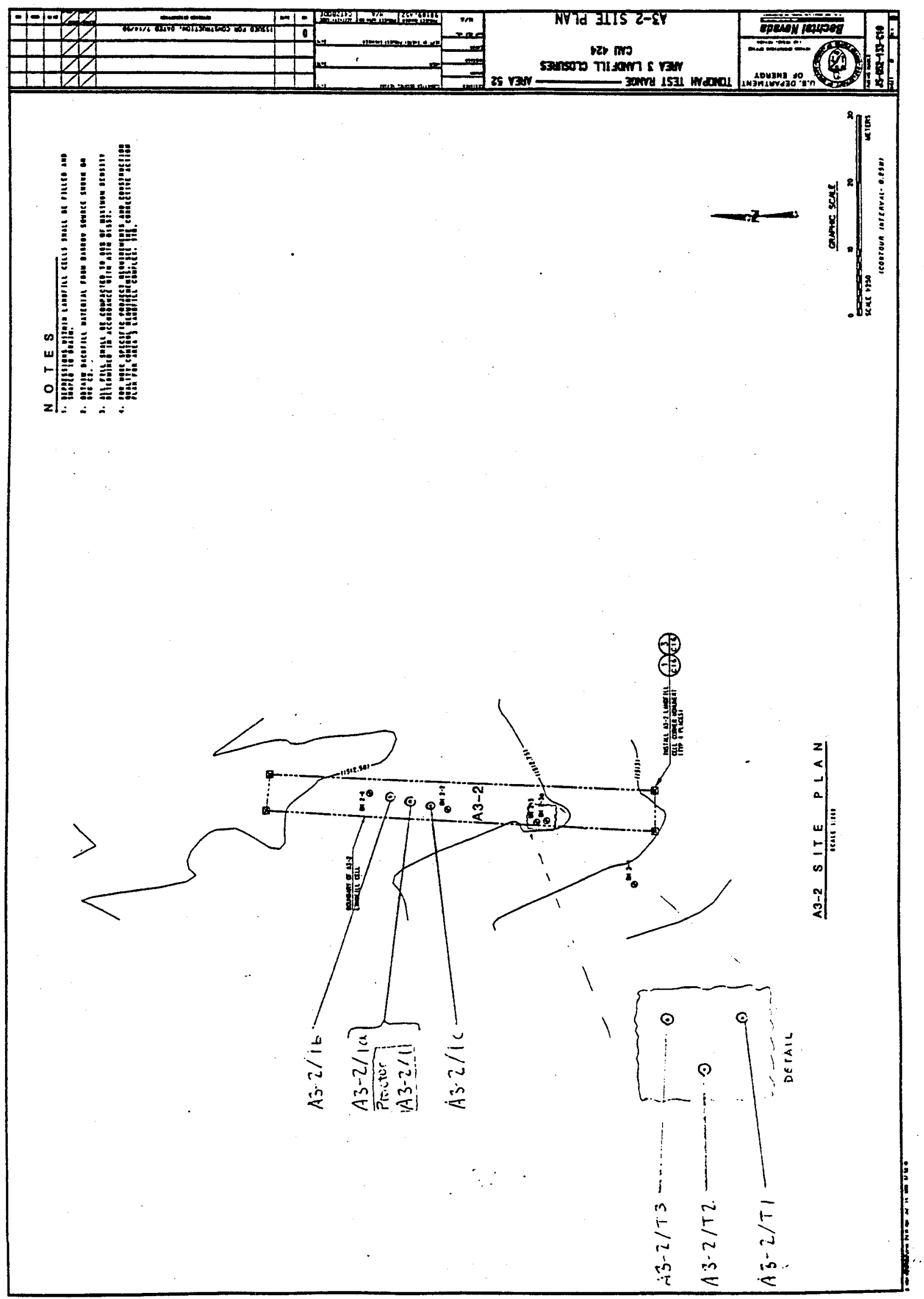




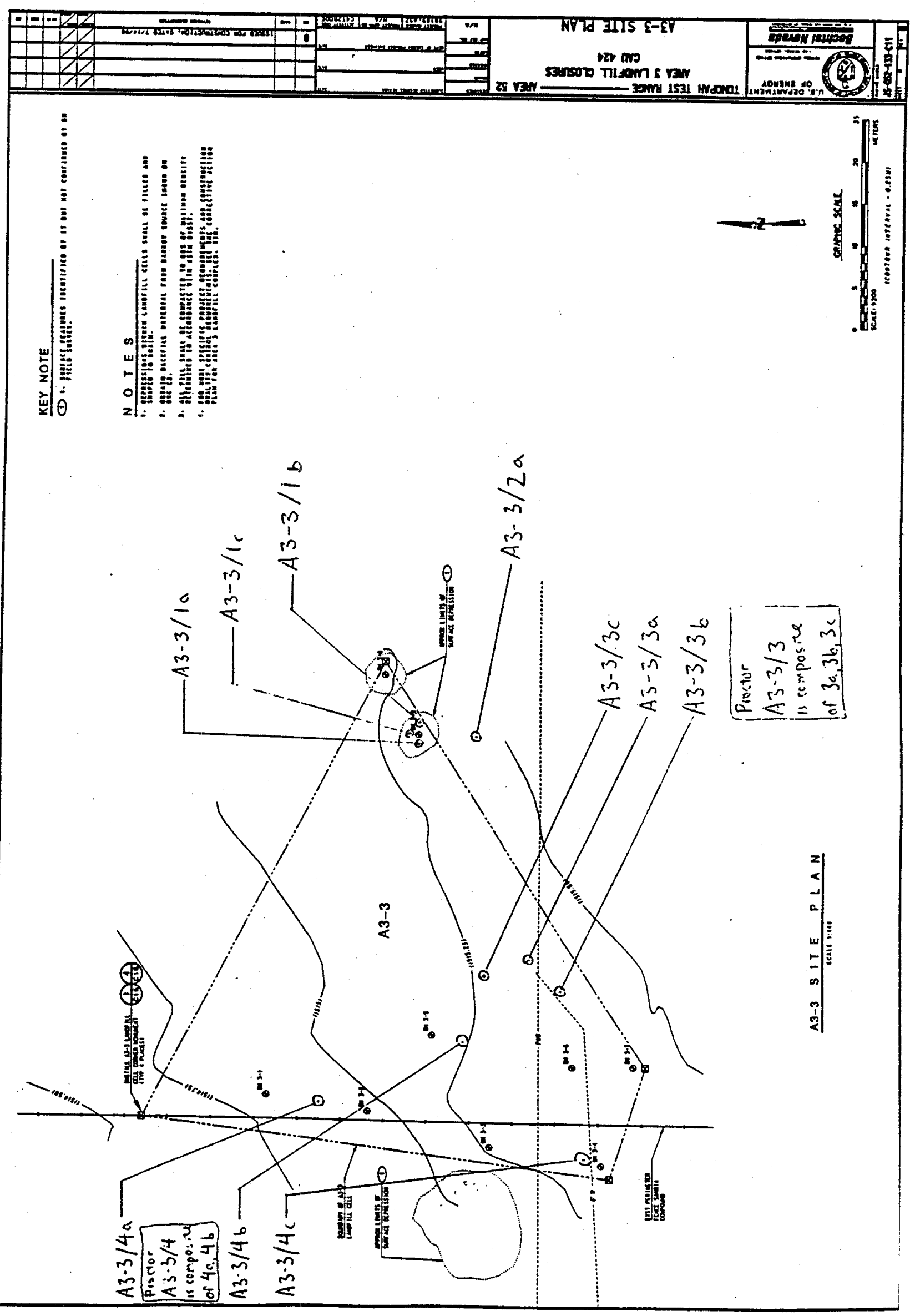




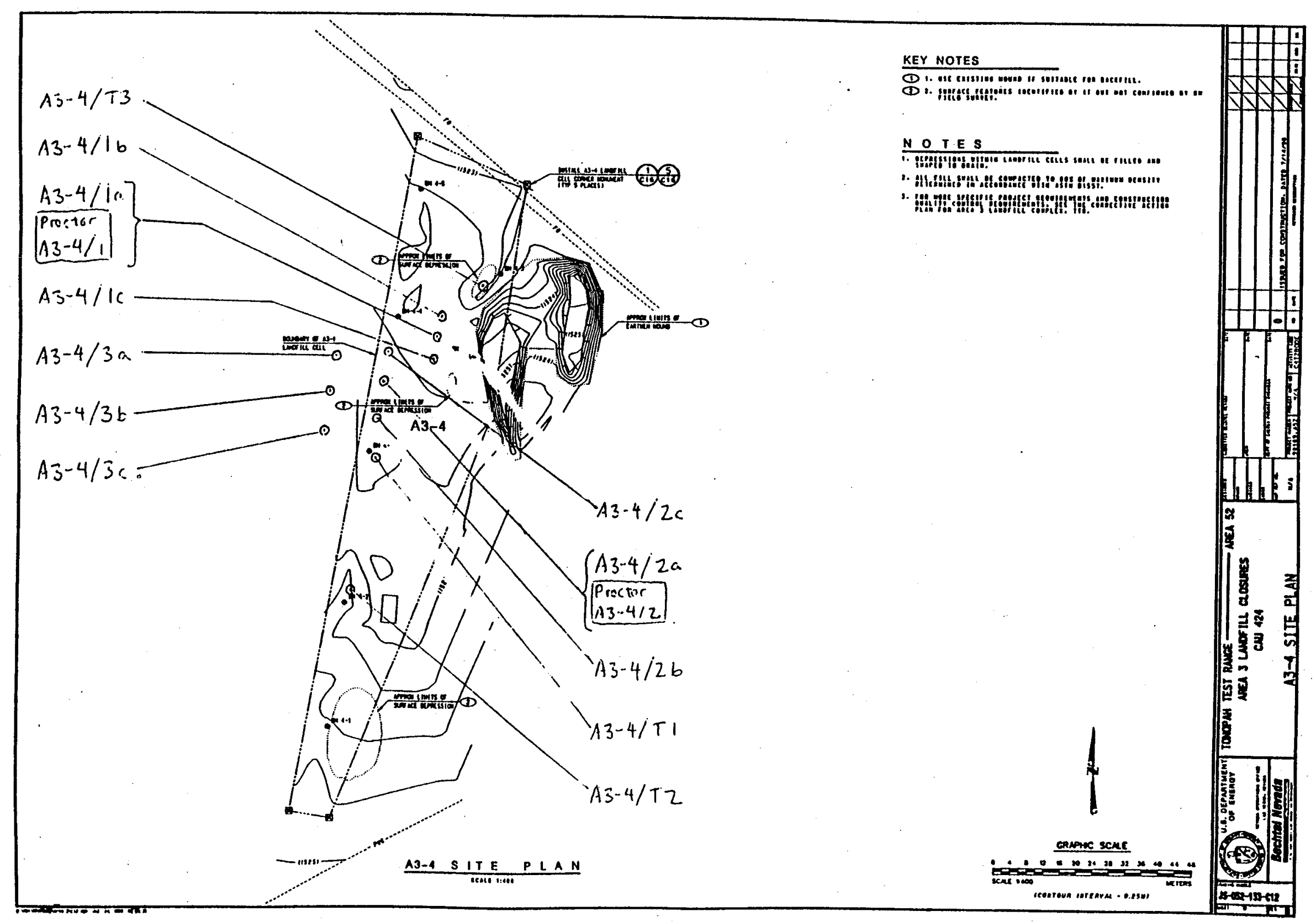




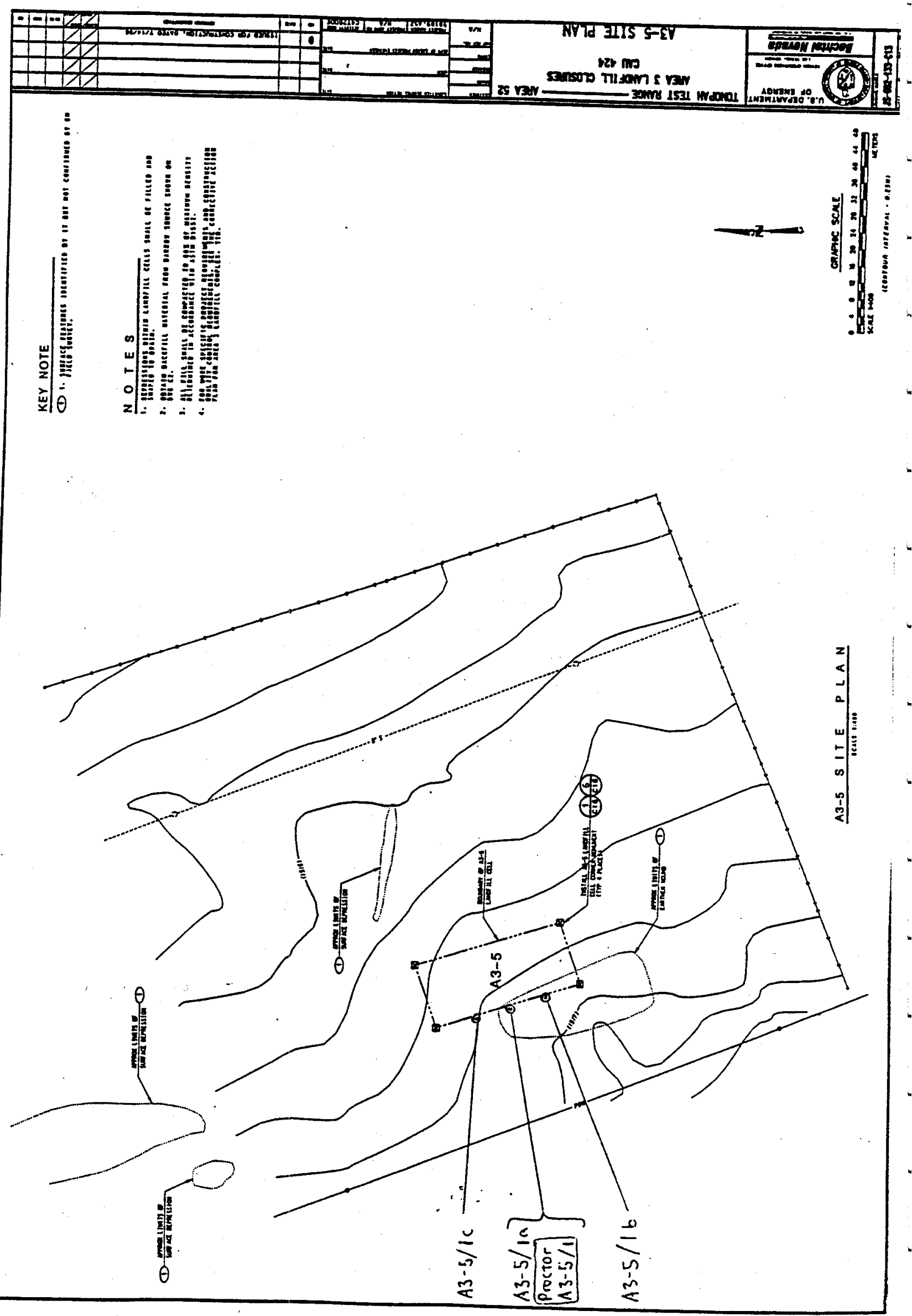




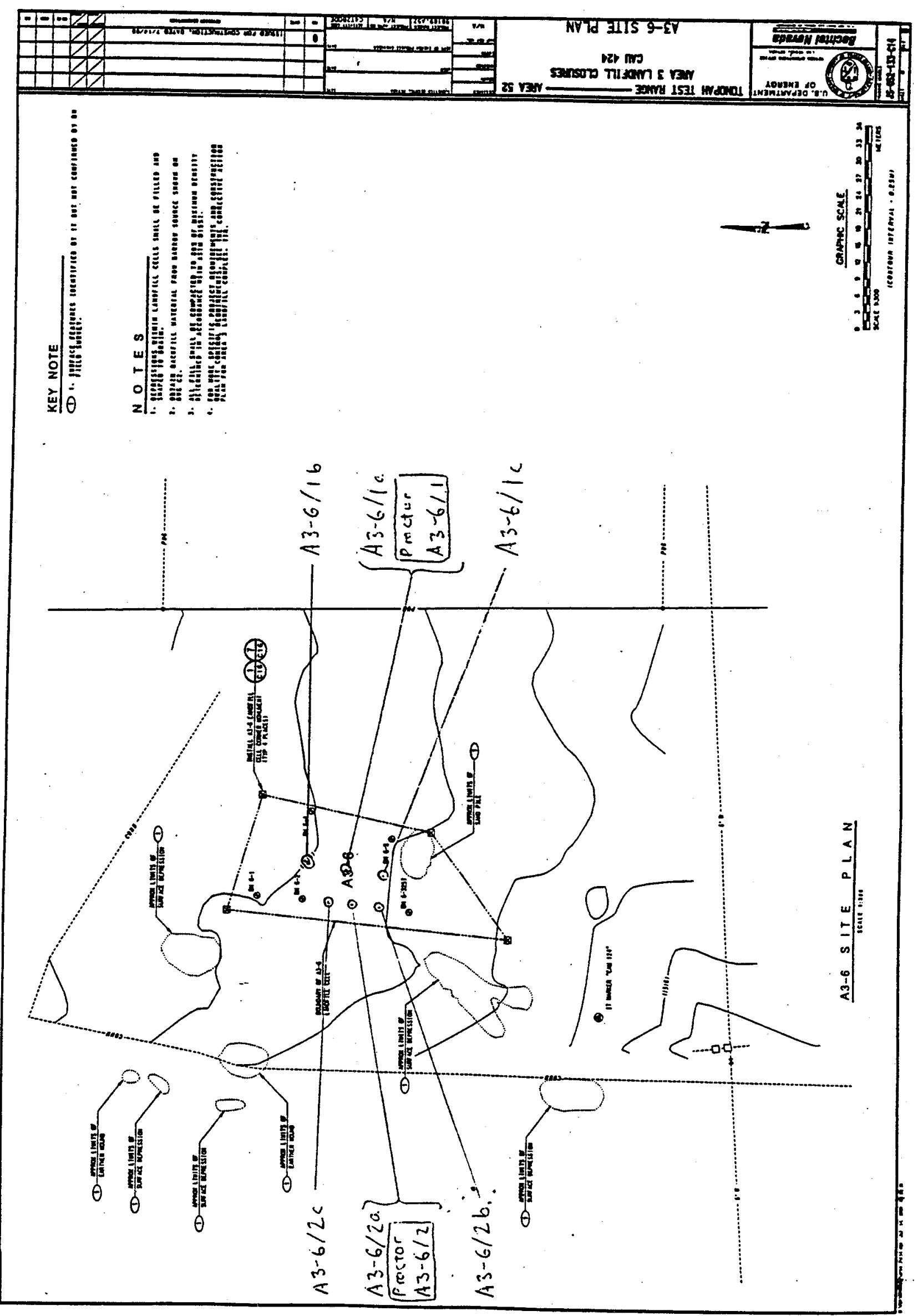


Revision: 0

Date: July 7, 1999

\section{APPENDIX E}

\section{USE RESTRICTION DOCUMENTATION}



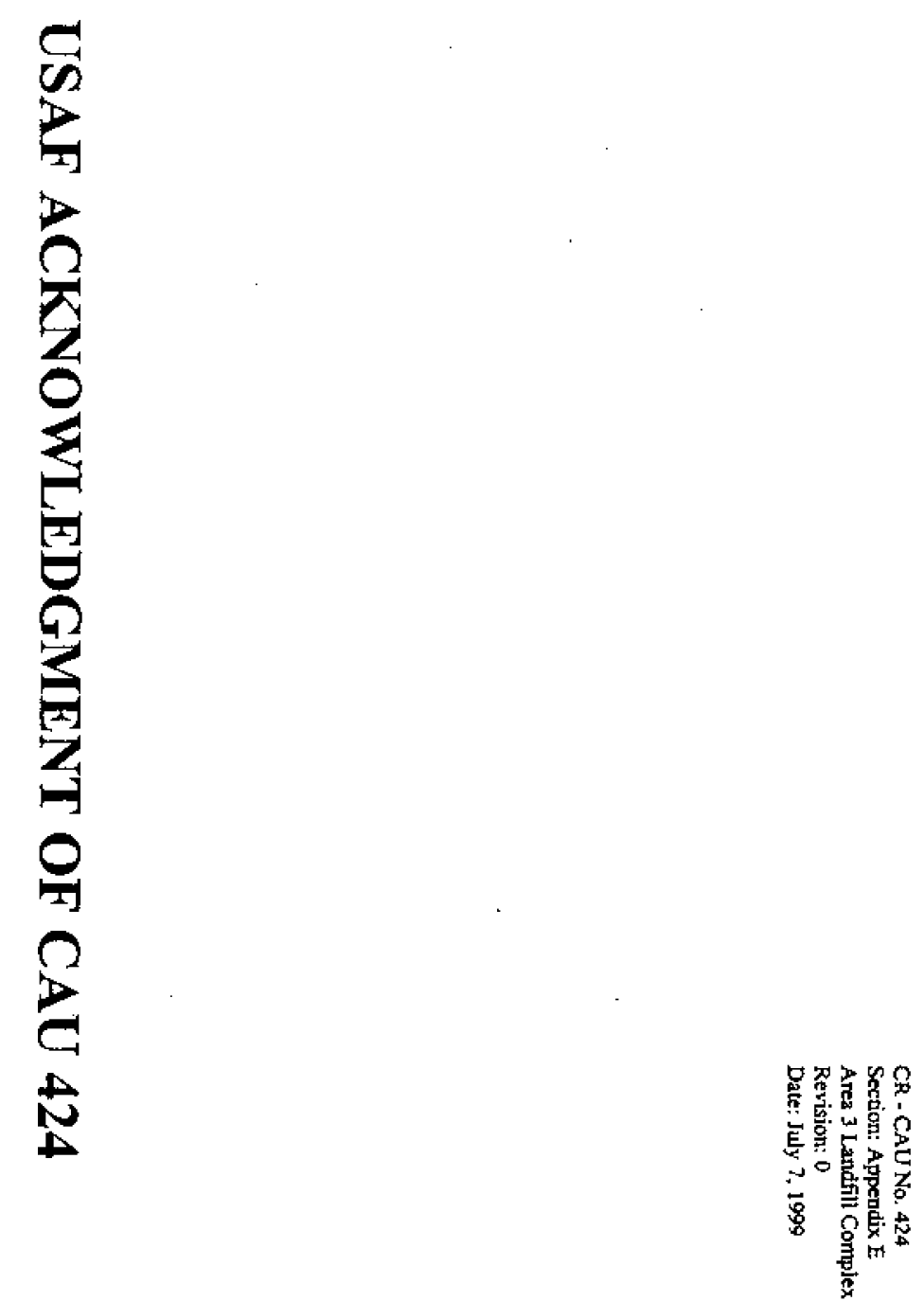


\section{DEPARTMENT OF THE AIR FORCE HEADQUARTERS 99TH AIR BASE WING (ACC) NELLIS 'AIR FORCE BASE, NEVADA}

Colonel Michael F. Fukey

JUL 151998

Director, Environmental Managernent

4349 Duffer Dr., Ste. 1601

Nellis AFB NV 89191-7007

Ms. Runore C. Wycoff,

Director, Environmental Restoration Division

DOE Nevada Operations Office

P.O. Box 98518

Las Vegas NV 89193-8518

\section{ACKNOWLEDGEMENT OF CORRECIIVE ACTION UNTT (CAU) 424}

Nellis Air Force Base (Nellis) has reviewed the U. S. Department of Energy's (DOE) Corrective Action Decision Document for Corrective Action Unit (CAU) 424. Nellis has the. right to use this land for military purposes under Public Law 99-606, as amended, and Public Land Order 7131.

Neliis can only impose restrictions on its use of the land while under its control. For the above referenced site, these self-imposed restrictions by Nellis on its use of this section of NAFR (hereafter "use restictions") will be placed in the Geographic Information System (GIS) for NAFR The Range Management Office (RMO) at Nellis will administer use restrictions to ensure that there are institutional controls on users of the NAFR, ensuring that they are aware.of these restrictions located in the GIS, which should assist the DOE in working with the state regulators on Corrective Active Units. If RMO determines that a proposed mission use would not comport with existing use restrictions or that there is a proposed transfer/relinquishment of all or part of the NAFR, it will notify DOE of the proposed transfer/relinquishment. Then DOE must contact the regulators or transferee/returnee to address and resolve cleanup issues associated with the proposed use or transfer/relinquishment.

If RMO needs to modify its use restrictions thereby causing additional cleanup requirements to meet the proposed land-use scenarios, then DOE will clean the restricted land up to the level to meet the proposed land-use scenarios in an expeditious manner so that RMO may amend the use restrictions. 
Also, Nellis and DOE are negotiating a Memorandum of Understanding that will address DOE's future obligations to clean up any of its contaminated areas.

Please contact me at 652-6828 if you have any questions.

\author{
Sincerely
}

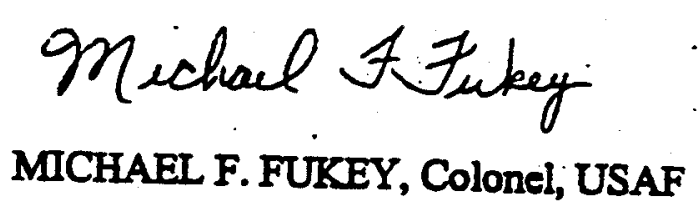

cc:

HQAWC RMO/RMI

HQ AWFCJAV 
Area 3 Landfill Complex

Revision: 0

Date: July 7, 1999

\section{CAU USE RESTRICTION INFORMATION FORMS}




\section{Nevada Operations Office}

Hil P. Box 98518

\section{APR 291999}

Colonel Michael F. Fukey, USAF

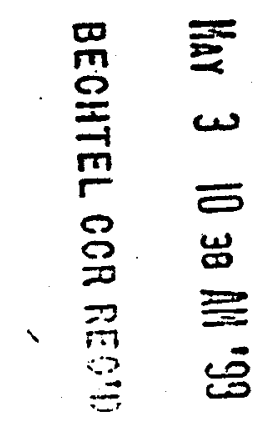

Director, Environmental Management

4349 Duffer Dr., Ste. 1601

Nellis AFB, NV 89191-7007

SUBMITTAL OF THE CAU USE RESTRICTION INFORMATION FORMS FOR CAU 424 AREA 3 LANDFILL COMPLEX, AND CAU 453 AREA 9 UNEXPLODED ORDNANCE LANDFILL

Please find enclosed copies of the subject CAU Use Restriction Information forms for your office to file in your GIS system. All sites are on the Tonopah Test Range. The use restriction coordinates are in UTM NAD83 (meters). A reply letter is requested stating that the use restriction information has been recorded.

If you have any questions, please contact Kevin J. Cabble, of my staff, at (702) 295-5000.

ERD:KJC

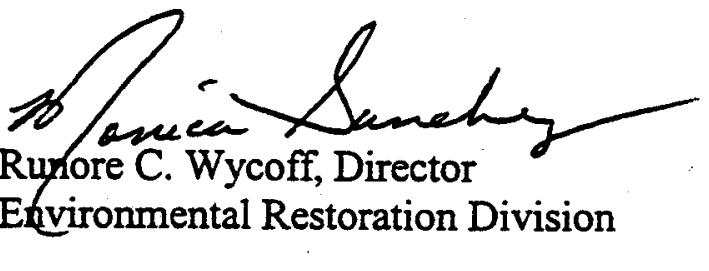

Enclosure:

As stated 
ce w/o encl:

Col. G. C. Carpenter, USAF Liaison, DOE/NV, Las Vegas, NV

P. J. Liebendorfer, NDEP, Carson City, NV

K. K. Beckley, NDEP, Carson City, NV

M. D. McKinnon, NDEP, Las Vegas, NV

J. J. Johnson, NDEP, Carson City, NV

D. A: Bedsun, DTRA, Mercury, NV

Vern Gabbard, SNL/TTR, Tonopah, NV

R. B. Jackson, IT, Las Vegas, NV

J. M. Moore, IT, Las Vegas, NV

L. F. Roos, IT, Las Vegas, NV

D. K. Cowser, BN, Las Vegas, NV

D. D. Madsen, BN, Mercury, NVNrs306

K. A. Hoar, ESHD, DOE/NV, Las Vegas, NV

R. C. Wycoff, ERD, DOE/NV, Las Vegas, NV

J. L. Appenzeller-Wing, ERD, DOE/NV, Las Vegas, NV

P. L. Hall, EM, DOE/NV, Las Vegas, NV 


\section{CAU Use Restriction Information}

CAU Number/Description: CAU 424 (Area 3 Landfill Complex. Tonopah Test Range, NV) Applicable CAS Numbers/Descriptions: CAS No. 03-08-001-A301 (Landfill A3-1)

Contact (organization/project):DOE/NV Industrial Sites Project Manager

Surveyed Area (UTMs):

\begin{tabular}{ll}
$4.182 .762 .49 \mathrm{mN}$, & $521.188 .69 \mathrm{mE} ;$ \\
\hline $4.182 .702 .25 \mathrm{mN}$, & $521.206 .86 \mathrm{mE} ;$ \\
$4.182 .637 .31 \mathrm{mN}$, & $521.224 .19 \mathrm{mE} ;$ \\
\hline $4.182 .630 .25 \mathrm{mN}$, & $521.150 .27 \mathrm{mE} ;$ \\
\hline $4.182 .707 .26 \mathrm{mN}$, & $521.143 .37 \mathrm{mE} ;$ \\
\hline $4.182 .710 .42 \mathrm{mN}$, & $521.158 .13 \mathrm{mE} ;$ \\
\hline $4.182 .752 .25 \mathrm{mN}$, & $521.155 .86 \mathrm{mE} ;$
\end{tabular}

Survey Date 11/20/1998 Survey Method (GPS, etc.) GPS

Datum NAD 83

Site Monitoring Requirements: Visual inspection as specified by the closure documentation

Required Frequency (quarterly, annually?): inspections biannually to commence six months after the closure concurrence date

\section{Use Restrictions}

The future use of any land related to this Corrective Action Unit (CAU), as described by the above surveyed location, is restricted from any DOE or Air Force activity that may alter or modify the containment control as approved by the state and identified in the CAU Closure Report or other CAU documentation unless appropriate concurrence is obtained in advance.

Comments: See the Closure Report for additional information on the condition of the site(s) and any monitoring and/or inspection requirements.

Submitted By:

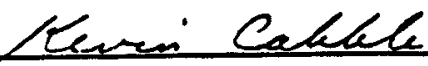

Date:

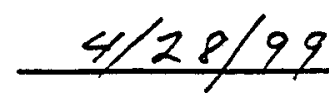

Attachments: Survey Map 


\section{CAU Use Restriction Information}

CAU Number/Description: CAU 424 (Area 3 Landfill Complex, Tonopah Test Range, NV)

Applicable CAS Numbers/Descriptions: CAS No. 03-08-002-A302 (Landfill A3-2)

Contact (organization/project): DOE/NV Industrial Sites Project Manager

Surveyed Area (UTMs):

$4.182 .504 .79 \mathrm{mN}, \quad 521.182 .38 \mathrm{mE}$

$4.182 .444 .76 \mathrm{mN}, \quad 521.182 .79 \mathrm{mE}$ :

$4.182,443.86 \mathrm{mN}_{2} \quad 521,173.80 \mathrm{mE}$

$4.182 .506 .17 \mathrm{mN}, \quad 521.175 .89 \mathrm{mE}$.

Survey Date 11/20/1998 Survey Method (GPS, etc.) GPS Datum NAD 83

Site Monitoring Requirements:__ Visual inspection as specified by the closure documentation

Required Frequency (quarterly, annually?):___ inspections biannually to commence six months after the closure concurrence date

\section{Use Restrictions}

The future use of any land related to this Corrective Action Unit (CAU), as described by the above surveyed location, is restricted from any DOE or Air Force activity that may alter or modify the containment control as approved by the state and identified in the CAU Closure Report or other CAU documentation unless appropriate concurrence is obtained in advance.

Comments: See the Closure Report for additional information on the condition of the site(s) and any monitoring and/or inspection requirements.

Submitted By:

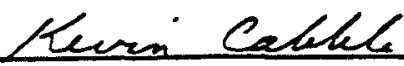

Date: 99 


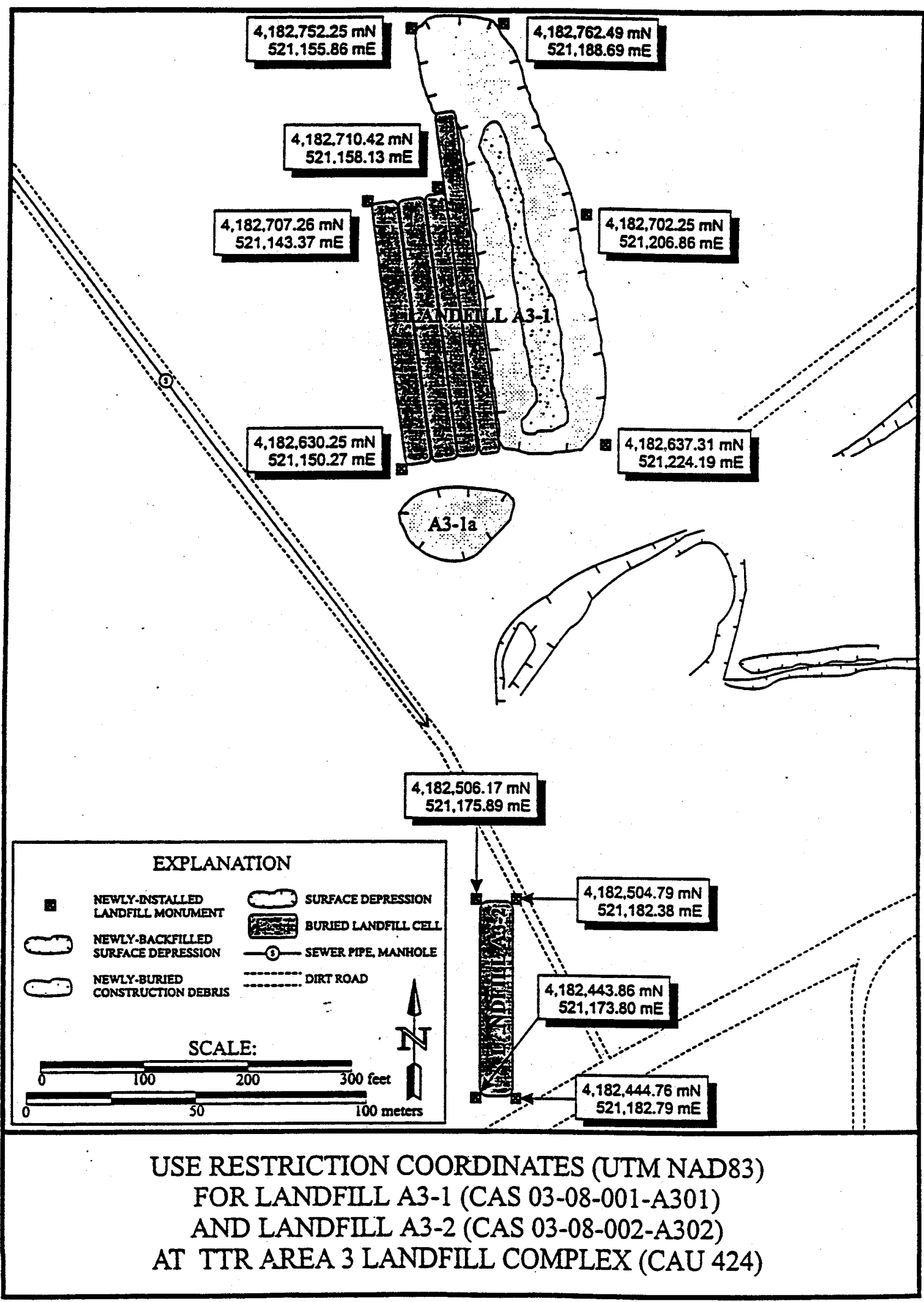




\section{CAU Use Restriction Information}

CAU Number/Description: CAU 424 (Area 3 Landfill Complex. Tonopah Test Range, NV)

Applicable CAS Numbers/Descriptions: CAS No. 03-08-002-A303 (Landfill A3-3)

Contact (organization/project): DOE/NV Industrial Sites Project Manager

Surveyed Area (UTMs):

$4,182.253 .25 \mathrm{mN}, \quad 521,263.47 \mathrm{mE}$

$4,182.224 .02 \mathrm{mN}, \quad 521,296.29 \mathrm{mE}$;

$4.182 .222 .87 \mathrm{mN}, \quad 521,299.12 \mathrm{mE}$;

$4.182 .221 .02 \mathrm{mN}, \quad 521.296 .85 \mathrm{mE}$ :

$4.182 .220 .35 \mathrm{mN}, \quad 521.263 .33 \mathrm{mE}$;

$4.182 .192 .94 \mathrm{mN}, \quad 521.263 .94 \mathrm{mE}$;

$4.182 .197 .99 \mathrm{mN}, \quad 521.242 .80 \mathrm{mE}$;

$4.182 .226 .89 \mathrm{mN}, \quad 521.246 .48 \mathrm{mE}$ :

$4.182,255.17 \mathrm{mN}, \quad 521,250,13 \mathrm{mE}$.

Survey Date $11 / 20 / 1998$ Survey Method (GPS, etc.) GPS_ Datum_NAD 83

Site Monitoring Requirements:__ Visual inspection as specified bv the closure documentation

Required Frequency (quarterly, annually?):_ inspections biannually to commence six months after the closure concurrence date

\section{Use Restrictions}

The future use of any land related to this Corrective Action Unit (CAU), as described by the above surveyed location, is restricted from any DOE or Air Force activity that may alter or modify the containment control as approved by the state and identified in the CAU Closure Report or other CAU documentation unless appropriate concurrence is obtained in advance.

Comments: See the Closure Report for additional information on the condition of the site(s) and any monitoring and/or inspection requirements.

Submitted By:

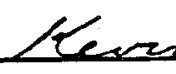

Cablet

Date:

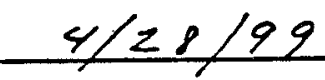

Attachments: Survey Map 


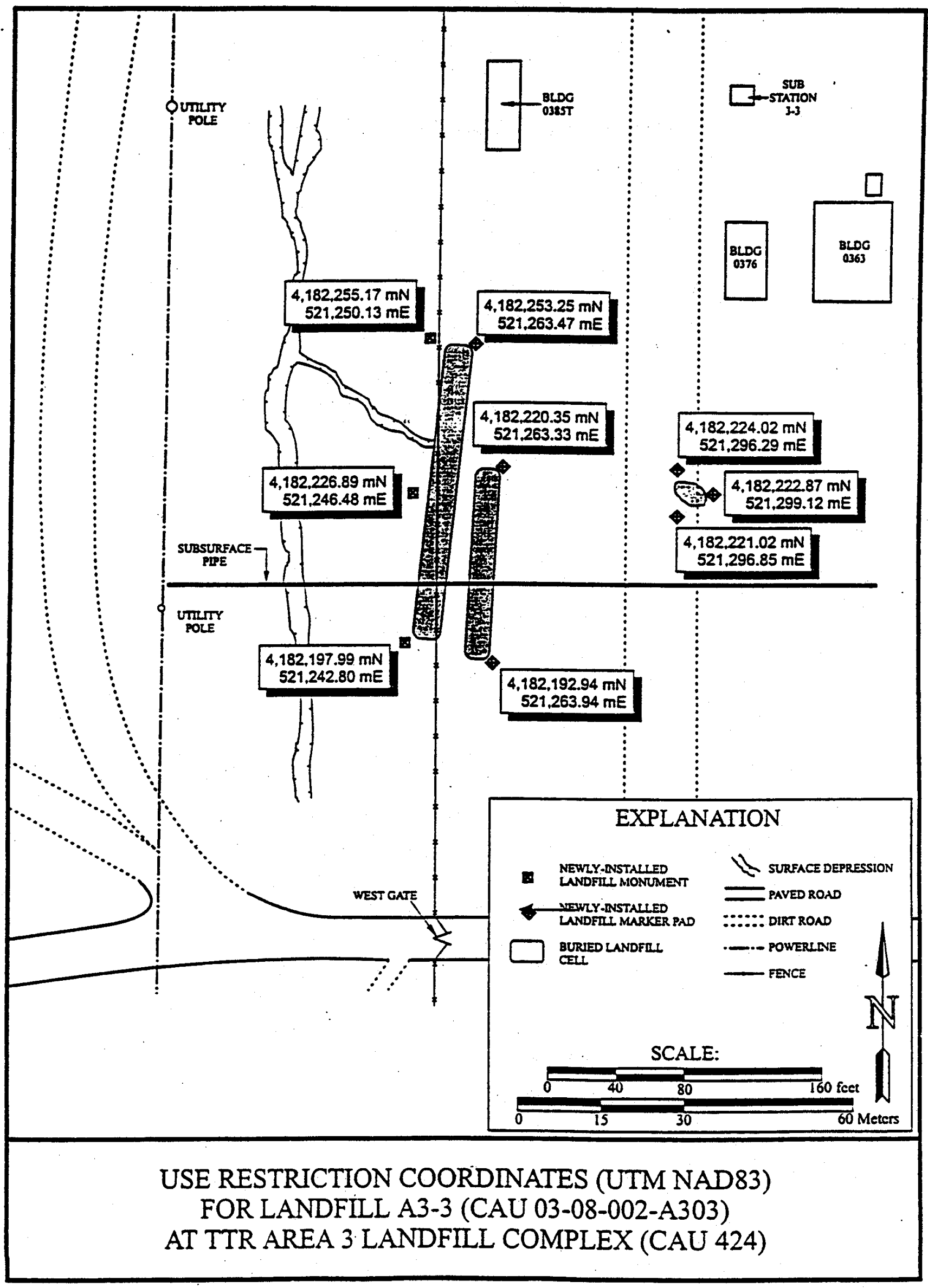




\section{CAU Use Restriction Information}

CAU Number/Description: CAU 424 (Area 3 Landfill Complex. Tonopah Test Range, NV)

Applicable CAS Numbers/Descriptions: CAS No. 03-08-002-A304 (Landfill A3-4)

Contact (organization/project): DOE/NV Industrial Sites Project Manager

Surveyed Area (UTMs):

$4,181,596.45 \mathrm{mN}, \quad 521.123 .78 \mathrm{mE}$;

$4,181,538.98 \mathrm{mN} . \quad 521,116.48 \mathrm{mE}$;

$4.181 .442 .33 \mathrm{mN}, \quad 521.080 .25 \mathrm{mE}$;

$4,181,444.21 \mathrm{mN}, \quad 521,067.64 \mathrm{mE}$ :

$4,181.543 .36 \mathrm{mN}, \quad 521,082.89 \mathrm{mE}$;

$4,181.609 .04 \mathrm{mN}, \quad 521.094 .90 \mathrm{mE}$.

Survey Date 11/20/1998 Survey Method (GPS, etc.) 'GPS Datum_NAD 83

Site Monitoring Requirements: Visual inspection as specified by the closure documentation

Required Frequency (quarterly, annually?):__ inspections biannually to commence six months after the closure concurrence date

\section{Use Restrictions}

The future use of any land related to this Corrective Action Unit (CAU), as described by the above surveyed location, is restricted from any DOE or Air Force activity that may alter or modify the containment control as approved by the state and identified in the CAU Closure Report or other CAU documentation unless appropriate concurrence is obtained in advance.

Comments: See the Closure Report for additional information on the condition of the site(s) and any monitoring and/or inspection requirements.

Submitted By:
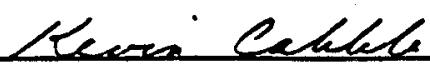

Date:

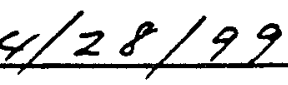

Attachments: Survey Map 


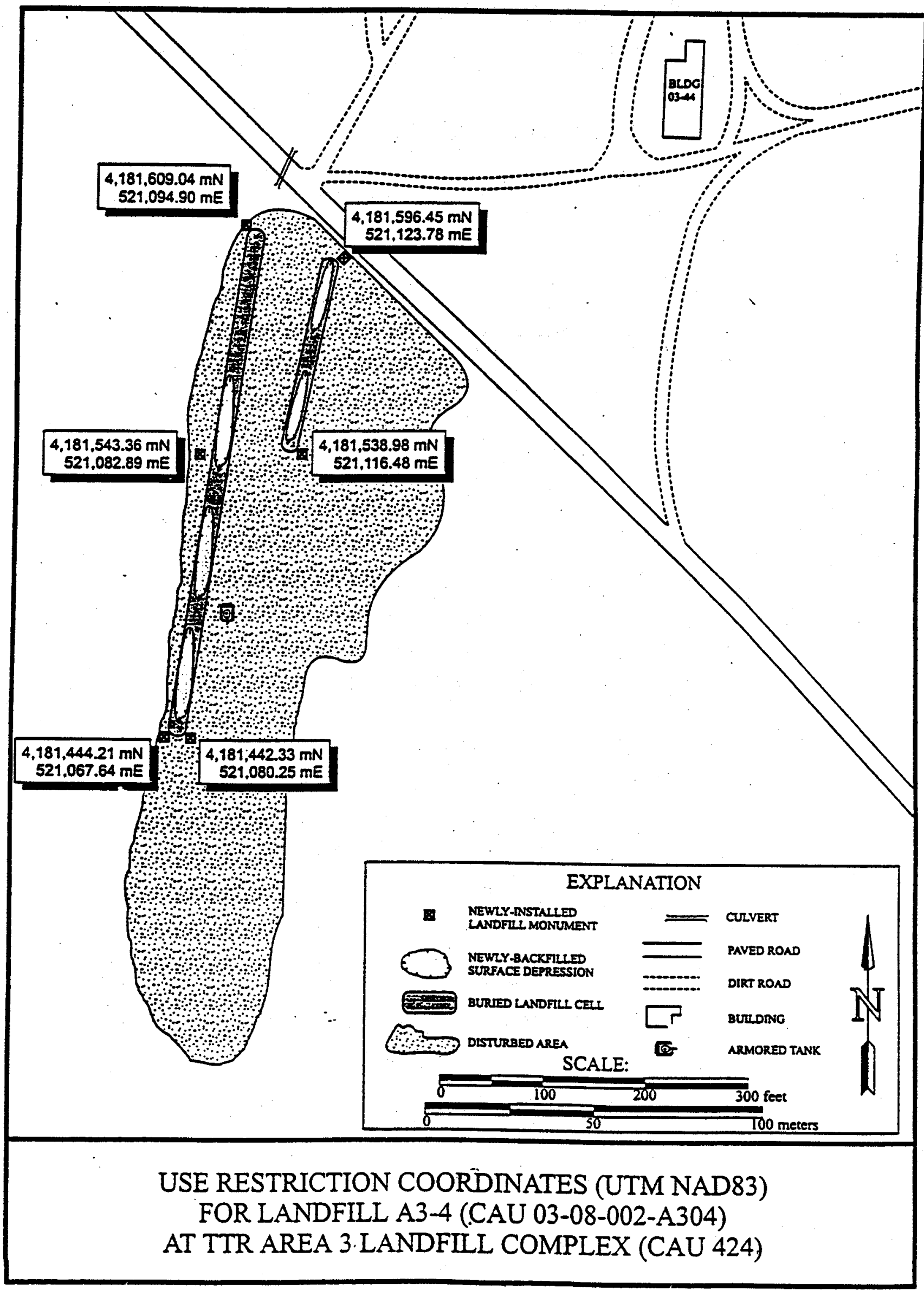




\section{CAU Use Restriction Information}

CAU Number/Description: CAU 424 (Area 3 Landfill Complex. Tonopah Test Range, NV)

Applicable CAS Numbers/Descriptions: CAS No. 03-08-002-A305 (Landfill A3-5)

Contact (organization/project): DOE/NV Industrial Sites Project Manager

Surveyed Area (UTMs):

$4.182 .315 .03 \mathrm{mN} \quad 520.893 .95 \mathrm{mE}$;

$4,182.280 .16 \mathrm{mN}, \quad 520,905.57 \mathrm{mE}$ :

$4,182.272 .93 \mathrm{mN}, \quad 520.885 .12 \mathrm{mE}$

$4,182,307.28 \mathrm{mN}, \quad 520,872.73 \mathrm{mE}$.

Survey Date 11/20/1998 Survey Method (GPS, etc.) GPS Datum_NAD 83

Site Monitoring Requirements: Visual inspection as specified bv the closure documentation

Required Frequency (quarterly, annually?):__ inspections biannually to commence six months after the closure concurrence date

\section{Use Restrictions}

The future use of any land related to this Corrective Action Unit (CAU), as described by the above surveyed location, is restricted from any DOE or Air Force activity that may alter or modify the containinent control as approved by the state and identified in the CAU Closure Report or other CAU documentation unless appropriate concurrence is obtained in advance.

Comments: See the Closure Report for additional information on the condition of the site(s) and anv monitoring and/or inspection requirements.

Submitted By:

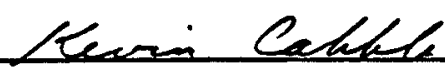

Date:

$4 / 28 / 99$

Attachments: Survey Map 


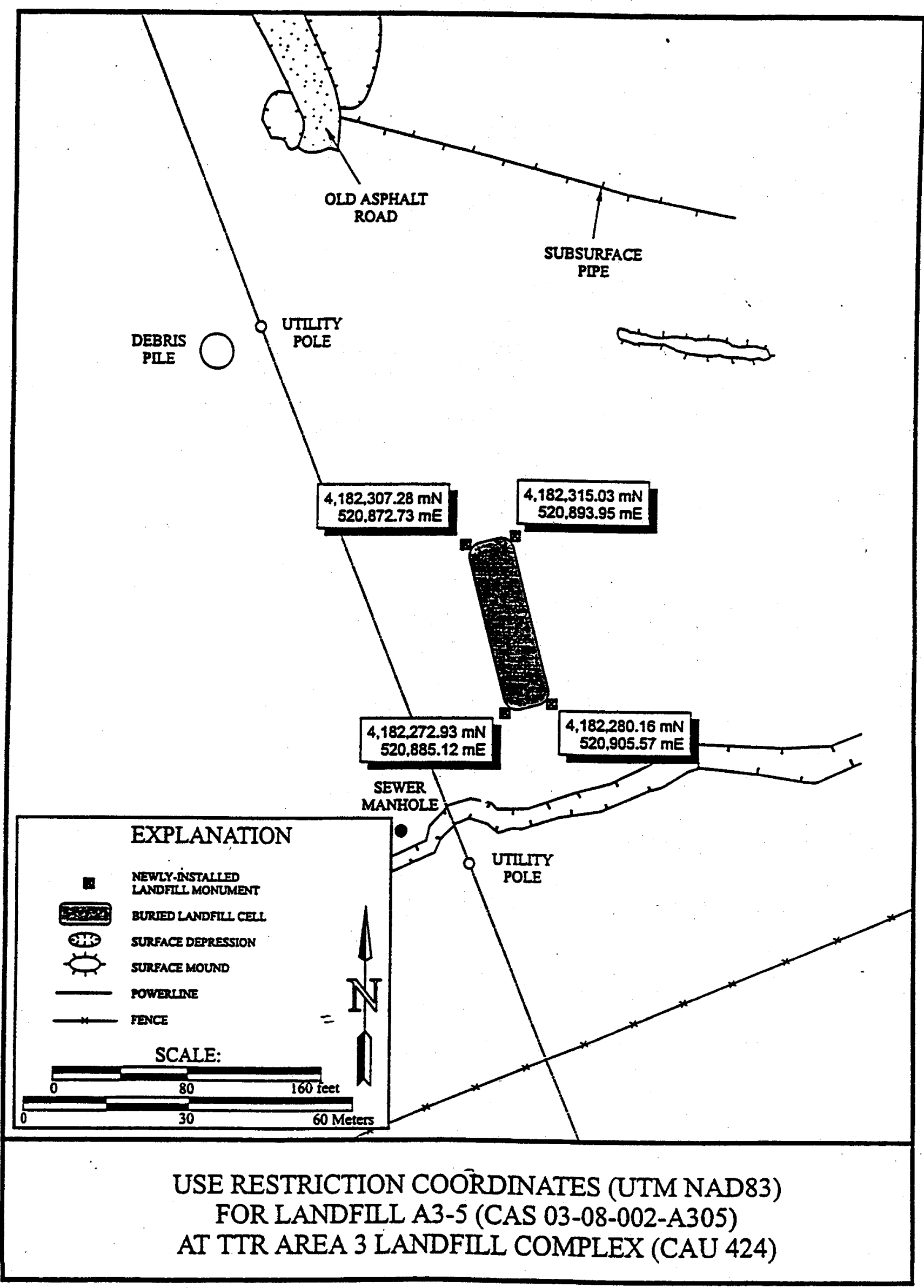




\section{CAU Use Restriction Information}

CAU Number/Description: CAU 424 (Area 3 Landfill Complex. Tonopah Test Range, NV)

Applicable CAS Numbers/Descriptions: CAS No. 03-08-002-A306 (Landfill A3-6)

Contact (organization/project): DOE/NV Industrial Sites Project Manager

Surveyed Area (UTMs):

$4,182.278 .68 \mathrm{mN}, \quad 521.167 .02 \mathrm{mE}$ :

$4,182,246.08 \mathrm{mN}, \quad 521,161.02 \mathrm{mE}$;

$4.182 .230 .93 \mathrm{mN}, \quad 521,138.17 \mathrm{mE}$;

$4,182.284 .90 \mathrm{mN}$. $\quad 521.143 .22 \mathrm{mE}$.

Survey Date 11/20/1998 Survey Method (GPS, etc.) GPS Datum_NAD 83

Site Monitoring Requirements: Visual inspection as specified by the closure documentation

Required Frequency (quarterly, annually?):__ inspections biannually to commence six months after the closure concurrence date

\section{Use Restrictions}

The future use of any land related to this Corrective Action Unit (CAU), as described by the above surveyed location, is restricted from any DOE or Air Force activity that may alter or modify the containment control as approved by the state and identified in the CAU Closure Report or other CAU documentation unless appropriate concurrence is obtained in advance.

Comments: See the Closure Report for additional information on the condition of the site(s) and any monitoring and/or inspection requirements.

Submitted By:

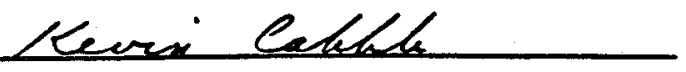

Date:

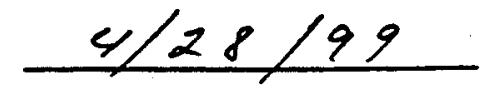

Attachments: Survey Map 


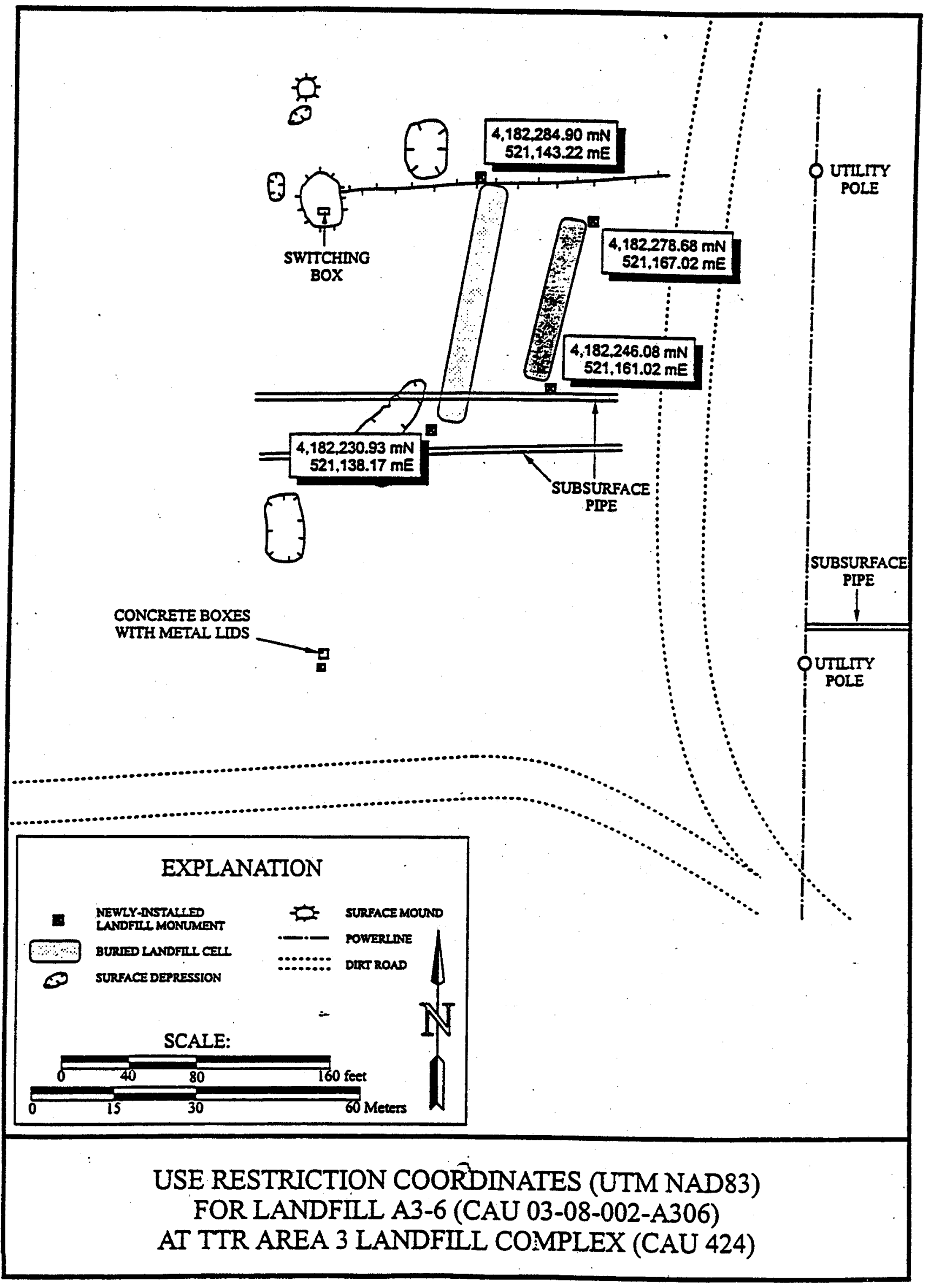




\section{CAU Use Restriction Information}

CAU Number/Description: CAU 424 (Area 3 Landfill Complex. Tonopah Test Range, NV)

Applicable CAS Numbers/Descriptions: CAS No. 03-08-002-A308 (Landfill A3-8)

Contact (organization/project): DOE/NV Industrial Sites Project Manager

Surveyed Area (UTMs):

$4.181 .867 .55 \mathrm{mN} . \quad 521.189 .63 \mathrm{mE}$;

$4.181 .813 .37 \mathrm{mN}, \quad 521.163 .36 \mathrm{mE}$;

$4.181 .837 .60 \mathrm{mN}, \quad 521.131 .12 \mathrm{mE}$ :

$4.181 .876 .58 \mathrm{mN}, \quad 521.172 .29 \mathrm{mE}$

Survey Date 11/20/1998 Survey Method (GPS, etc.) GPS Datum NAD 83

Site Monitoring Requirements:_ Visual inspection as specified bv the closure documentation

Required Frequency (quarterly, annually?):__ inspections biannually to commence six months after the closure concurrence date

\section{Use Restrictions}

The future use of any land related to this Corrective Action Unit (CAU), as described by the above surveyed location, is restricted from any DOE 0 . Air Force activity that may alter or modify the containment control as approved by the state and identified in the CAU Closure Report or other CAU documentation unless appropriate concurrence is obtained in advance.

Comments: See the Closure Report for additional information on the condition of the site(s) and any monitoring and/or :aspection requirements.

Submitted By:

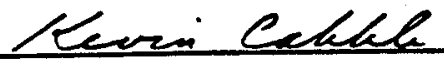

Date:

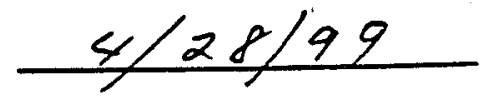

Attachments: Survey Map 


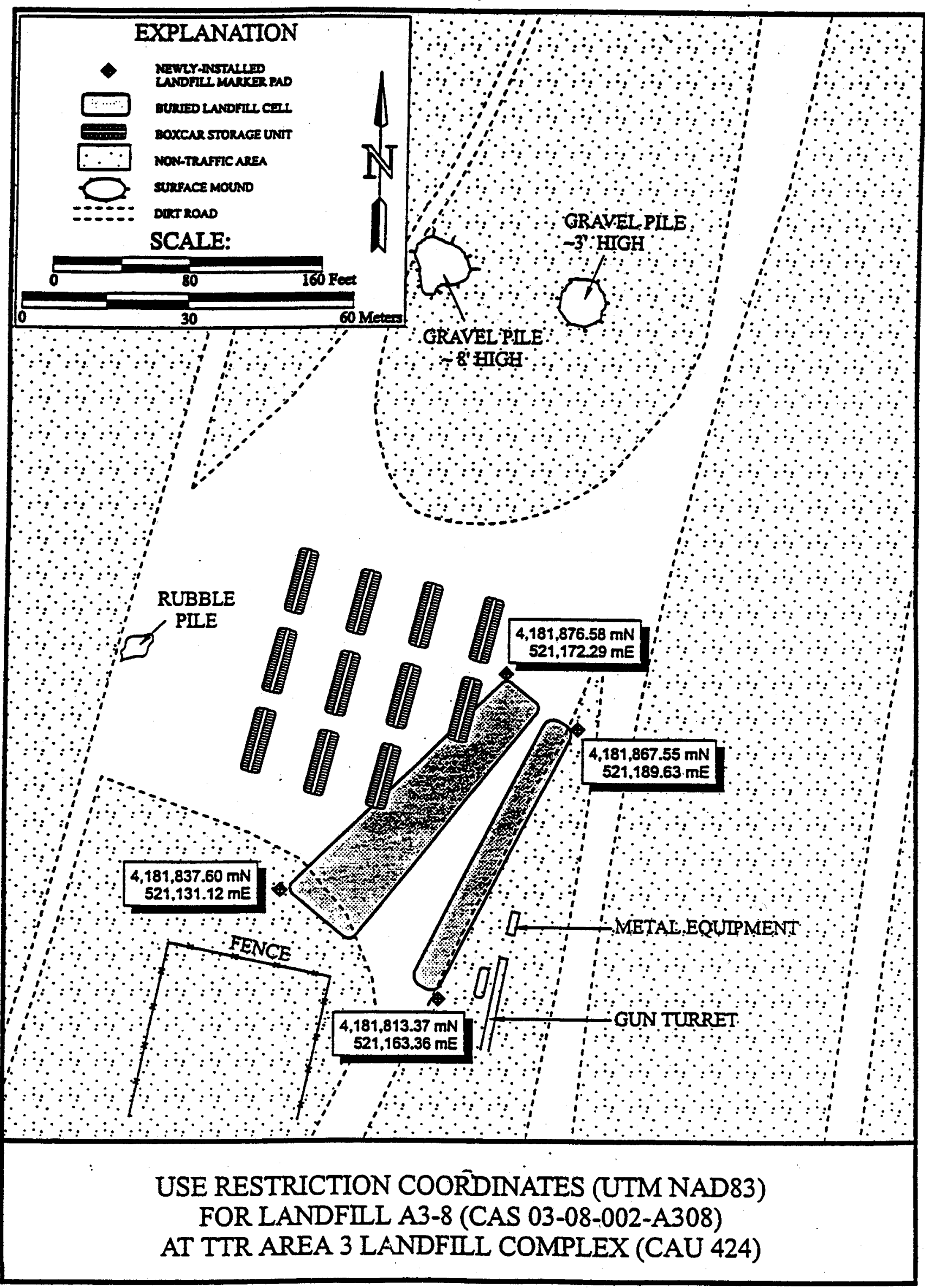


Revision: 0

Date: July 7, 1999

\section{USAF RECORDATION OF CAU 424}




\section{DEPARTMENT OF THE AIR FORCE HEADQUARTERS 99TH AIR BASE WING (ACC) \\ NELLIS AIR FORCE BASE, NEVADA}

Ms. Eloisa Hopper

1 Jul 99

Director, Environmental Management

4349 Duffer Drive, Suite 1601

Nellis AFB NV 89191-7007

Ms. Runore C. Wycoff

Director, Environmental Restoration Branch

DOE Nevada Operations Office

P.O. Box 98518

Las Vegas NV 89193-8518

RECORDATION OF CORRECTIVE ACTION UNIT (CAU) 424

Nellis Air Force Base (Nellis) has recorded the U.S. Department of Energy's Use Restriction Information for Corrective Action. Unit (CAU) 424. The information was placed in the Geographic Information System at the Range Management Office, Nellis.

Please contact me at $652-4123$ if you have any questions.

Sincerely,

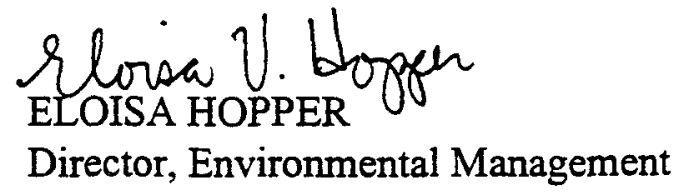

cc:

NDEP

HQ AWC RMO/RML

HQ AWFC/JAV 


\begin{tabular}{|l|l|}
\hline AREA 3 LANDFILL COMPLEX, POST-CLOSURE INSPECTION CHECKLIST \\
\hline \hline Date of Last Inspection: & Reason for Last Inspection: \\
\hline Responsible Agency: & Project Manager: \\
\hline inspection Date: & \\
\hline Inspector (name, title, organization): \\
\hline Assistant inspector (name, title, organization): \\
\hline \hline
\end{tabular}

\section{A. GENERAL INSTRUCTIONS}

1. All checklist items must be completed and detailed comments made to document the results of the site inspection. The completed checklist is part of the field record of the inspection. Additional pages should be used as necessary to ensure that a complete record is made. Attach the additional pages and number all pages upon completion of the inspection.

3. Any checklist line item marked by an inspector in a SHADED BOX, must be fully explained or an appropriate reference to previous reports provided. The purpose of this requirement is to provide a written explanation of inspector observations and the inspector's rationale for conclusions and recommendations. Explanations are to be placed on additional attachments and crossreferenced appropriately. Explanations, in addition to narrative, will take the form of sketches, measurements, annotated site maps.

4. The site inspection is a walking inspection of the entire site including the perimeter and sufficient transects to be able to inspect the entire surface and all features specifically described in this checklist.

5. A standard set of color $35 \mathrm{~mm}$ photographs (or equivalent) is required. In addition, all anomalous features or new features (such as changes in adjacent area land use) are to be photographed. A photo log entry will be made for each photograph taken.

6. This unit will be inspected biannually with formal reporting to the Nevada Division of Environmental Protection to be done annually. The annual report will include an executive summary, this inspection checklist with field notes and photo log attached, and recommendations and conclusions.

B. PREPARATION (To be completed prior to site visit)

1. Site as-built plans and site base map reviewed.

2. Previous inspection reports reviewed.

a. Were anomalies or trends detected on previous inspections?

b. Was maintenance performed?

3. Site maintenance and repair records reviewed.

a. Has site repair resulted in a change from as-built conditions?

b. Are revised as-builts available that reflect repair changes?

C. SITE INSPECTION (To be completed during inspection)

\begin{tabular}{|l|l|l|}
\hline YES & NO & EXPLANATION \\
\hline & & \\
\hline & & \\
\hline & & \\
\hline & & \\
\hline & & \\
\hline & & \\
\hline YES & NO & EXPLANATION \\
\hline
\end{tabular}

1. Adjacent off-site features within watershed areas.

a. Have there been any changes in use of adjacent area?

b. Are there any new roads or trails?

c. Has there been a change in the position of nearby washes?

d. Has there been lateral excursion or erosion/deposition of nearby washes?

e. Are there new drainage channels?

f. Change in surrounding vegetation?

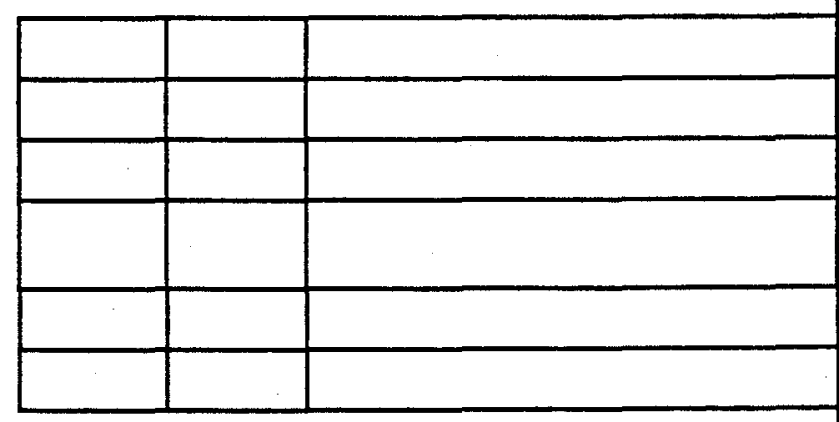

2. Security fence, signs.

a. Displacement of fences, site markers, boundary markers, or monuments?

b. Have any signs been damaged or removed? (Number of signs replaced: )

c. Were gates locked?

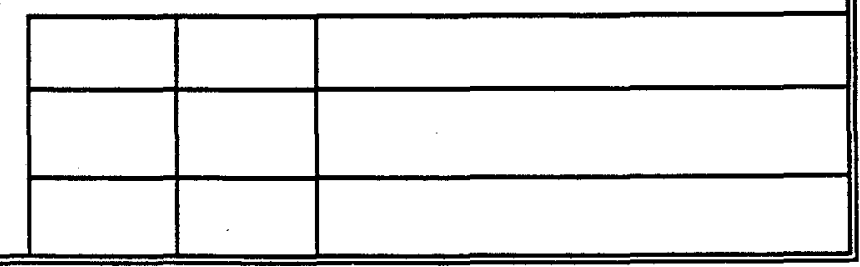




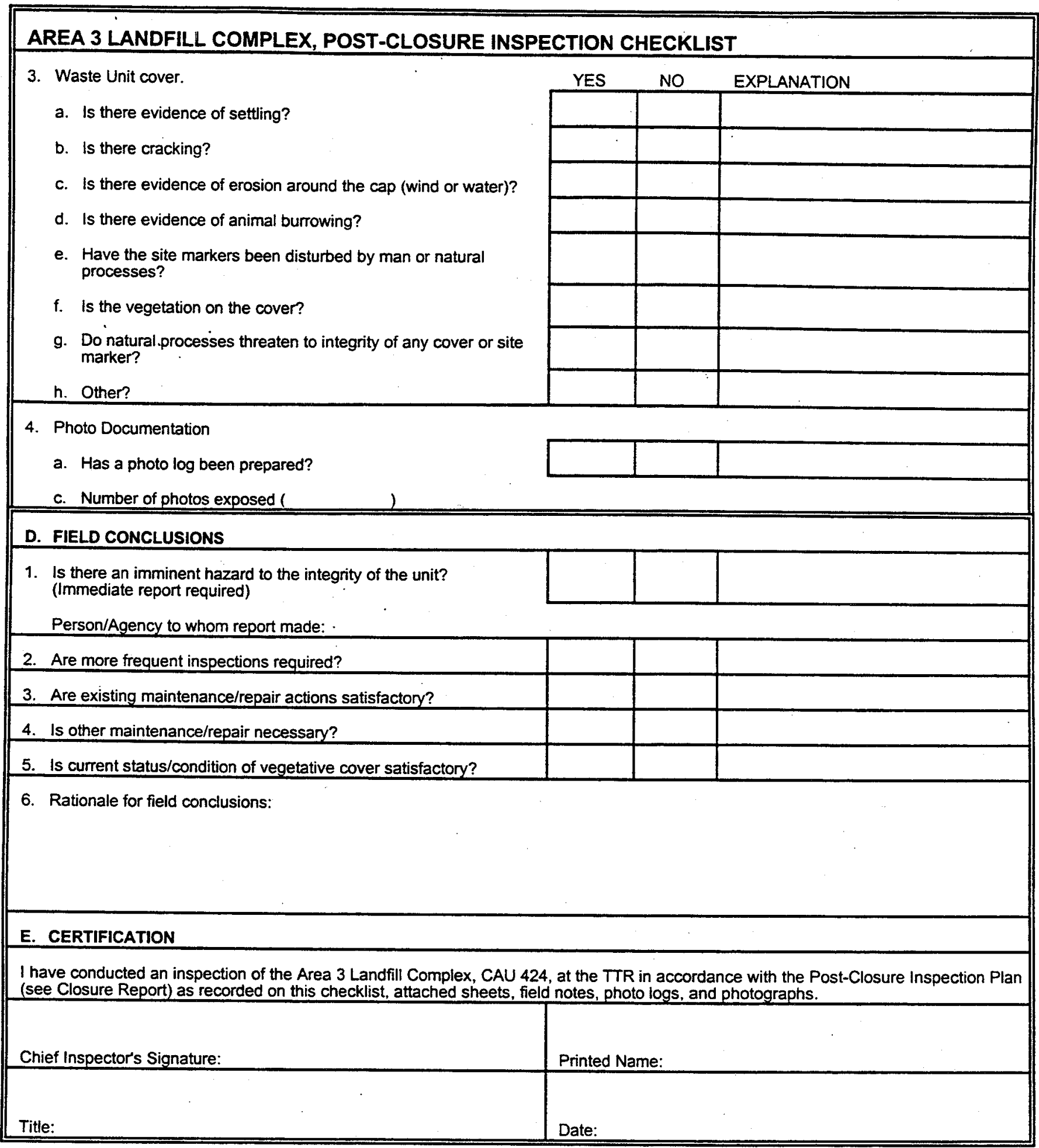




\section{APPENDIX G}

NDEP DOCUMENT REVIEW SHEET 


\section{DOCUMENT REVIEW SHEET}

\begin{tabular}{|c|c|c|c|c|}
\hline \multicolumn{5}{|c|}{$\begin{array}{l}\text { 1. Document Title/Number: Draft Closure Report for Corrective Action Unit 424: } \\
\text { Nevada, December } 1998 \\
\text { 2. Document Date: December } 1998 \\
\text { 3. Revision Number: 0 } \\
\text { 4. Originator/Organization: Curtis Obi, Bechtel Nevada Environmental Restoration } \\
\text { 5. Date Comments Due: January 7, } 1999 \\
\text { 6. Reviewer/Organization: Nevada Division of Environmental Protection (NDEP) }\end{array}$} \\
\hline $\begin{array}{l}\text { 7. Comment } \\
\text { Number/ } \\
\text { Location } \\
\end{array}$ & $\begin{array}{c}8 . \\
\text { Type }^{a}\end{array}$ & 9. Comment & 10. Comment Response & $\begin{array}{l}11 . \\
\text { Accept }\end{array}$ \\
\hline 1 & M & $\begin{array}{l}\text { Page } 12 \text {, bullet item } 2 \text { and } 3 \text {. There appears } \\
\text { to be a discrepancy between these two } \\
\text { bullets with respect to } 03-80-002-A 307 \text {. The } \\
\text { Landfill either had action taken or didn't, not } \\
\text { both. Also, bullet } 2 \text { makes reference to } 03- \\
80-002-A 309 \text {. There were only eight } \\
\text { landfills and this is probably a typographical } \\
\text { error. }\end{array}$ & $\begin{array}{l}\text { Text in second bullet of Section } 1.2 \text { has } \\
\text { been revised with the following changes: } \\
03-80-002-\mathrm{A} 307 \text { has been removed } \\
\text { because it was mistakenly included; 03- } \\
80-002-\mathrm{A} 309 \text { does not exist and has been } \\
\text { corrected to } 03-80-002-\mathrm{A} 308 \text {. }\end{array}$ & Yes \\
\hline 2 & M & $\begin{array}{l}\text { Page 16. The decisions above need to be } \\
\text { consistent with what is reported in table } 2 \text {. }\end{array}$ & $\begin{array}{l}\text { Revisions in response to Comment } 1 \text { are } \\
\text { now consistent with Table } 2 \text {. }\end{array}$ & Yes \\
\hline
\end{tabular}


DOCUMENT REVIEW SHEET

\begin{tabular}{|c|c|c|c|c|}
\hline $\begin{array}{l}\text { 7. Comment } \\
\text { Number/ } \\
\text { Location } \\
\end{array}$ & $\begin{array}{c}8 . \\
\text { Type }^{\mathrm{a}}\end{array}$ & 9. Comment & 10. Comment Response & $\begin{array}{c}11 . \\
\text { Accept }\end{array}$ \\
\hline 3 & M & $\begin{array}{l}\text { Page 20. This page discusses "average" } \\
\text { density and compaction. While averages are } \\
\text { important to give an overall picture of the } \\
\text { site, high and low values are critical to } \\
\text { making decisions that are in line with regs. }\end{array}$ & $\begin{array}{l}\text { Text in Section } 2.1 .2 .2 \text { has been revised } \\
\text { and geotechnical results are now only } \\
\text { discussed in Section } 4 \text { where the range of } \\
\text { field compaction results for each test } \\
\text { location are presented. }\end{array}$ & Yes \\
\hline 4 & M & $\begin{array}{l}\text { Page 28. The permeability results in Table } 5 \\
\text { need to be presented consistently with } \\
\text { information presented in previous } \\
\text { documents. Depth is a factor to be } \\
\text { considered when discussing permeability } \\
\text { and reporting values. It should be } \\
\text { demonstrated that the adjacent soil is more } \\
\text { permeable that the caps otherwise, the caps } \\
\text { on the landfills appear to be less protective } \\
\text { and actually create a "sponge" effect. Also, } \\
\text { include a discussion as to why it may be } \\
\text { acceptable to provide less protection than the } \\
\text { minimum regulatory requirements that were } \\
\text { proposed to be utilized as guidance in } \\
\text { closure of this site. }\end{array}$ & $\begin{array}{l}\text { Appropriate permeability results from the } \\
\text { CADD have been added to Table } 5 \text { and } \\
\text { are included in the Section } 4 \text { permeability } \\
\text { discussion which states that, except for } \\
\text { Landfill A3-3, the permeabilities of } \\
\text { existing landfill covers are less than, or } \\
\text { comparable to, the permeabilities of } \\
\text { adjacent native soils, indicating that } \\
\text { preferential infiltration over the waste } \\
\text { cells is unlikely. For Landfill A3-3, the } \\
\text { discussion states that the potential for } \\
\text { preferential infiltration at Landfill A3-3 } \\
\text { was minimized with the construction of a } \\
\text { shallow drainage channel to divert } \\
\text { surface water run on. }\end{array}$ & Yes \\
\hline
\end{tabular}


CR - CAU No. 424

Section: Distribution

Area 3 Landfill Complex

Revision: 0

Date: July 7, 1999

DISTRIBUTION LIST 


\section{DISTRIBUTION LIST}

* Provide copy of initial distribution of Revision 0 ; remainder of list gets Revision 0 if approved by NDEP without changes. The entire list receives Revision 1, if issued.

\section{Nevada Department of Environmental Protection}

Paul Liebendorfer

Bureau of Federal Facilities

2* (Controlled)

Division of Environmental Protection

333 W. Nye Lane, Room 13B

Carson City, NV 89706-0866

Michael McKinnon

Bureau of Federal Facilities

$1^{*}$ (Controlled)

Division of Environmental Protection

555 E. Washington, Suite 4300

Las Vegas, NV 89010

\section{U.S. Department of Energy}

Janet Appenzeller-Wing

1* (Uncontrolled)

Environmental Restoration Division

U. S. Department of Energy, Nevada Operations Office

P. O. Box $98518, \mathrm{M} / \mathrm{S} 505$

Las Vegas, NV 89193-8518

Sabrina Lawrence

Environmental Restoration Division

$1 *$ (Controlled)

U. S. Department of Energy, Nevada Operations Office

P. O. Box 98518 , M/S 505

Las Vegas, NV 89193-8518

Kevin J. Cabble

Environmental Restoration Division

$1^{*}$ (Uncontrolled)

U. S. Department of Energy, Nevada Operations Office

P. O. Box 98518 , M/S 505

Las Vegas, NV 89193-8518 


\section{DISTRIBUTION (continued)}

\section{U.S. Department of Energy (continued)}

DOE Public Reading Room

1 (Controlled)

P. O. Box 98521, M/S NLV040

Las Vegas, NV 89193-8521

Manager

Southern Nevada FFACO Public Reading Room

Manager

Northern Nevada FFACO Public Reading Room

Technical Information Resource Center

Environmental Restoration Division

U. S. Department of Energy, Nevada Operations Office

P. O. Box $98518, \mathrm{M} / \mathrm{S} 505$

Las Vegas, NV 89193-8518

U. S. Department of Energy, Office of Scientific and Technical Information

P. O. Box 62

Oak Ridge, TN 37831

\section{Bechtel Nevada}

Correspondence Control

Bechtel Nevada

P. O. Box 98521 , M/S NLV008

Las Vegas, NV 89193-8521

Environmental Management Library

Bechtel Nevada

P. O. Box 98521, M/S NLV080

Las Vegas, NV 89193-8521

David K. Cowser

1* (Uncontrolled)
1 (Controlled)

1 (Uncontrolled)

1 (Uncontrolled)

1 (Uncontrolled)

1 (Electronic)
$1^{*}$ (Uncontrolled)

Bechtel Nevada

P. O. Box 98521 , M/S NLV082

Las Vegas, NV 89193-8521 


\section{DISTRIBUTION LIST (continued)}

\section{Bechtel Nevada (continued)}

Ann Heidema

1 (Uncontrolled)

Bechtel Nevada

P. O. Box $98521, \mathrm{M} / \mathrm{S}$ NLV102

Las Vegas, NV 89193-8521

David D. Madsen

$1 *$ (Uncontrolled)

Bechtel Nevada

P. O. Box 98521 , M/S NTS306

Las Vegas, NV 89193-8521

Steve J. Nacht

$1 *$ (Uncontrolled)

Bechtel Nevada

P. O. Box 98521 , M/S NTS306

Las Vegas, NV 89193-8521

Curtis M. Obi

$1^{*}$ (Uncontrolled)

Bechtel Nevada

P. O. Box 98521 , M/S NTS306

Las Vegas, NV 89193-8521

\section{IT Corporation}

Rosa Silver, Coordinator, FFACO Public Reading Room

1 (Controlled)

IT Corporation

P. O. Box 93838 , M/S 439

Las Vegas, NV 89193-3838

\section{U.S. Air Force}

Eloisa V. Hopper

3* (Controlled)

$99 \mathrm{ABW} / \mathrm{EM}$

4349 Duffer Drive Suite 1601

Nellis AFB, NV 89191-7007

Major Roger Schofield

$1 *$ (Controlled)

AWFC RMO/RML

3770 Duffer Drive

Nellis AFB, NV 89191-7001 